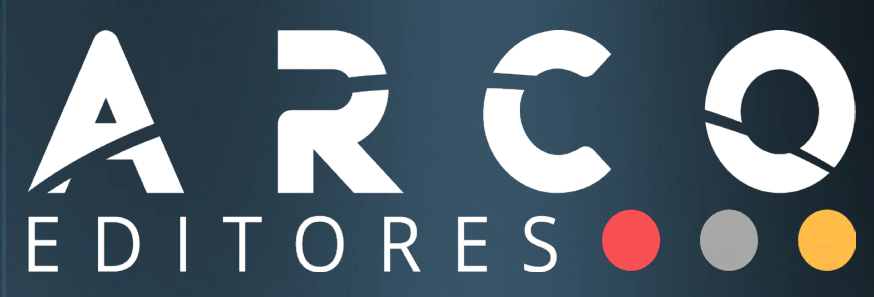

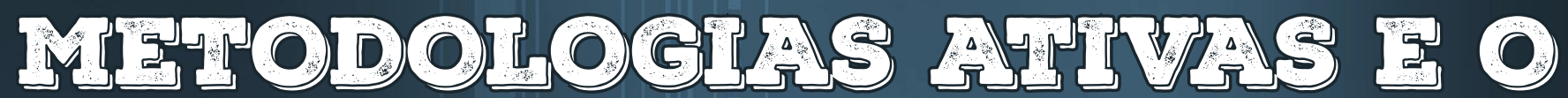

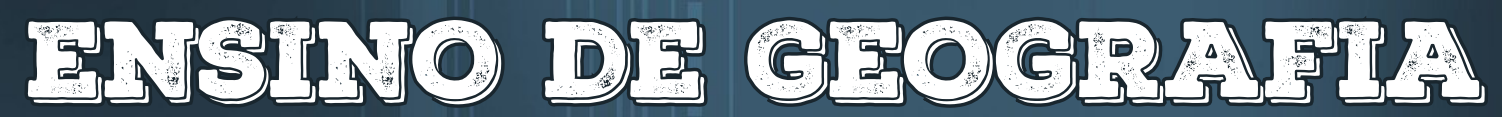

\section{GILVAN CHARLES CERQUEIRA DE ARAÚJO SIDELMAR ALVES DA SILVA KUNZ JÚLIO CÉSAR SUZUKI}

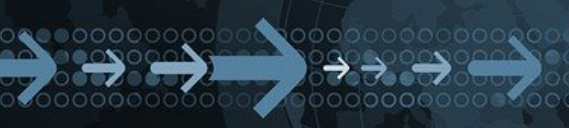

[Organizadores] 


\section{FICHA CATALOGRÁFICA}

Dados Internacionais de Catalogação na Publicação (CIP) (Câmara Brasileira do Livro, SP, Brasil)

Metodologias ativas e o ensino de geografia [livro eletrônico] / organizaçăo Gilvan Charles Cerqueira de Araújo, Sidelmar Alves da Silva Kunz, Júlio César Suzuki. -- 1. ed. -- Santa Maria : Arco Editores, 2021.

PDF

ISBN $978-65-994306-8-8$

1. Aprendizagem ativa 2. Ensino - Metodologia 3. Geografia - Estudo e ensino I. Araújo, Gilvan Charles Cerqueira de. II. Kunz, Sidelmar Alves da Silva. III. Suzuki, Júlio César.

CDD -910.7

Índices para catálogo sistemático:

1. Geografia : Estudo e ensino 910.7

Aline Graziele Benitez - Bibliotecária - CRB-1/3129

$10.48209 / 978-65-994306-8-8$

$1^{\text {a} E d i c ̧ a ̃ o ~-~ C o p y r i g h t @ ~} 2021$ do/as autores/as. 
Arco Editores.

\section{DIAGRAMAÇÃO E PROJETO GRÁFICO}

Arco Editores.

\section{REVISÃO}

Dos/as Autores/as.

\section{CONSELHO EDITORIAL}

Prof. Dr. Adilson Tadeu Basquerot e Silva - UNIDAVI/SC

http://lattes.cnpq.br/8318350738705473

Profa. Msc. Jesica Wendy Beltrán -UFCE- Colômbia

http://lattes.cnpq.br/0048679279914457

Profa. Dra Fabiane dos Santos Ramos UFSM- Santa Maria/RS

http://lattes.cnpq.br/0003382878348789

Dr. João Riél Manuel Nunes Vieira de Oliveira Brito -

UAL - Lisboa- Portugal.

http://lattes.cnpq.br/1347367542944960

Profa. Dra. Alessandra Regina Müller Germani -

UFFS- Passo Fundo/RS

http://lattes.cnpq.br/7956662371295912

Prof. Dr. Everton Bandeira Martins UFFS - Chapecó/SC

http://lattes.cnpq.br/9818548065077031

Prof. Dr. Erick Kader Callegaro Corrêa UFN- Santa Maria/RS

http://lattes.cnpq.br/2363988112549627

Prof. Dr. Pedro Henrique Witchs - UFES - Vitória/ES

http://lattes.cnpq.br/3913436849859138

Prof. Dr.Thiago Ribeiro Rafagnin UFOB

http://lattes.cnpq.br/3377502960363268
Prof. Dr. Mateus Henrique Köhler UFSM- Santa Maria/RS

http://lattes.cnpq.br/5754140057757003

Profa. Dra. Liziany Müller Medeiros UFSM- Santa Maria/RS

http://lattes.cnpq.br/1486004582806497

Prof. Dr. Camilo Darsie de Souza -

UNISC- Santa Cruz do Sul/RS

http://lattes.cnpq.br/4407126331414

Prof. Dr. Dioni Paulo Pastorio - UFRGS Porto Alegre/RS

http://lattes.cnpq.br/7823646075456872

Prof. Dr. Leonardo Bigolin Jantsch -

UFSM- Palmeira das Missões/RS http://lattes.cnpq.br/0639803965762459

Prof. Dr. Leandro Antônio dos Santos -UFU- Uberlândia/MG http://lattes.cnpq.br/4649031713685124

Dr. Rafael Nogueira Furtado UFJF- Juiz de Fora/MG

http://lattes.cnpq.br/9761786872182217

Profa. Dra. Angelita Zimmermann UFSM- Santa Maria/RS

http://lattes.cnpq.br/7548796037921237

Profa. Dra. Francielle Benini Agne Tybusch -

UFN- Santa Maria/RS

http://lattes.cnpq.br/4400702817251869 


\section{APRESENTAÇÃO}

Como "tudo tem um início", abrimos esse prefácio sinalizando que este livro por intermédio dos seus autores enfrentou a missão de disponibilizar para a comunidade acadêmica e os demais interessados uma produção que, em essência, se configura como um mapa com grande potencial para alargar a compreensão das possibilidades de utilização das metodologias ativas no ensino de Geografia.

Somente a partir de um trabalho conjunto, colaborativo e participativo de autores e organizadores o livro Metodologias Ativas e o ensino de Geografia se tornou realidade. $E$, mais que isto, uma conquista para os profissionais da educação que trabalham em diferentes funções e papeis no processo de ensino e aprendizagem, de gestores a professores, acadêmicos das ciências educacionais e estudantes de graduação e pós-graduação que se dedicaram ou realizam pesquisas e trabalhos voltados às temáticas educacionais atinentes à Geografia.

As transformações e desafios no processo de ensino e aprendizagem perfazem a realidade da prática pedagógica em sua totalidade. Especificidades e contradições, experiências exitosas e experimentações de instrumentação de ensino e diferentes recursos didáticos, a inserção escalar das redes de ensino que se diferenciam desde o impacto dos planos educacionais às singularizações de orientações e construções curriculares e formas de oferta diferenciais para etapas e modalidades educacionais.

O campo de estudo é amplo e profícuo, e as metodologias ativas vão ao encontro destes caminhos de exploração dos estudos educacionais e, em particular em sua correlação com o ensino de Geografia como tratamos neste livro.

É interessante darmos relevo ao fato de que as metodologias ativas são tratadas, também, como fundamentais em face dos atuais desafios didático-pedagógicos que demandam reflexão e constituição de novos fazeres docentes, como os que estamos enfrentando devido ao contexto do ensino na pandemia do novo coronavírus e todo o cenário atual de impactos causados pela COVID-19 no Brasil e no mundo. Repensar práticas, teorias e experiências didático-pedagógicas vai ao encontro do escopo temático, analítico e de aplicação das metodologias ativas em situações exitosas e desafiadoras em diferentes contextos educacionais. 
Nesse horizonte temático de ampla proficuidade e diversidade elementos como a formação continuada de professores, a construção curricular, os cenários estruturais de escolas e ambientes de ensino e aprendizagem, as perspectivas de trabalho de professores e professoras, as diferentes metas e estratégias de aprendizagem em etapas e modalidades da educação básica se apresentam como um meio de grande potencial para o desenvolvimento e disseminação das metodologias ativas adaptadas à realidade do ensino de Geografia, haja vista que cada vez mais se requer uma concepção de educação que seja capaz de promover o engajamento e a colaboração de todos os envolvidos no processo educativo com ênfase na aprendizagem significativa e no desenvolvimento do pensamento crítico e propositivo

Destacamos, ainda, que, para além dos referenciais basilares da geografia, os autores dos capítulos fizeram uso de relevantes pensadores consagrados em outros campos do conhecimento, como são os casos de Jean Piaget, Cipriano Luckesi, Erenildo Carlos, Paulo Freire, Gerd Bornheim, Edgar Dale, José Moran, Carolyn Wilson, Antoni Zabala, Maurice Tardif, Lev Vigotsky, Lilian Bacich, John Dewey, Pierre Lévy, Michel Young, Waldomiro Vergueiro, José Libâneo, dentre outros.

A estes autores somam-se as diferentes correntes de pensamento, particularidades e diversidade do pensamento geográfico possíveis de serem aplicadas às proposições educacionais nas etapas e modalidades das redes de ensino. Este diálogo entre as ciências da educação e o pensamento, prática e formação em Geografia é tanto visível como um dos aspectos que buscamos fortalecer da ideação à concretização do livro que agora apresentamos, de forma interdisciplinar, dialógica e com diferentes perspectivas de apresentação, conhecimento, problematização, desenvolvimento e aplicação das metodologias ativas no ensino de Geografia.

Os trabalhos que compõem o presente livro também vão ao encontro de uma perspectiva plural, dialógica e diversificada de atuação na educação básica e ensino superior. A Geografia estabelece, desta maneira, um importante ponte interdisciplinar envolvendo o seu escopo teórico, metodológico e de experiências na prática didático-pedagógica. As metodologias ativas ocupam um papel central e protagonista neste objetivo principal, sendo a temática a partir da qual diferentes formações, atuações profissionais, olhares e vivências são apresentados na forma dos capítulos da obra. 
Desse modo, é uma grande oportunidade de aprendizado para o leitor, uma vez que o trabalho permite realizar aprofundamento sobre a temática das metodologias ativas e as suas alternativas para aplicação no ensino de geografia. Tendo como pano de fundo a tradição do pensamento geográfico associada à literatura de fronteira da área de geografia. E a composição da obra se desenvolve intercalando tal arcabouço com as principais concepções pedagógicas da atualidade verticalizadas na temática central do livro.

Gilvan Charles Cerqueira de Araújoำ Sidelmar Alves da Silva Kunz² Júlio César Suzuki ${ }^{3}$ (Organizadores)

$1 \quad$ Doutor em Geografia pela Universidade Estadual Paulista “Júlio de Mesquita Filho" (UNESP). Mestre em Geografia pela Universidade de Brasília (UnB). Licenciado em Geografia Universidade Estadual Paulista Júlio de Mesquita Filho (UNESP). Professor de Geografia da Secretaria de Estado de Educação do Distrito Federal, Pós-doutorando de Geografia pela Universidade de São Paulo (USP)... E-mail: gcca99@gmail.com.

2 Doutor em Educação pela Universidade de Brasília (UnB). Mestre em Geografia Universidade de Brasília (UnB). Licenciado em Geografia pela Universidade Estadual de Goiás (UEG). Pesquisador do Instituto Nacional de Estudos e Pesquisas Educacionais Anísio Teixeira. E-mail: sidel. gea@gmail.com.

3 Graduado em Geografia (UFMT, 1992) e em Letras (UFPR, 2004), com mestrado (USP, 1997) e doutorado (USP, 2002) em Geografia Humana e estágio pós-doutoral na Université Panthéon-Sorbonne (2007-2008), Université Rennes 2 (2014-2015) e Université de Pau et des Pays de l'Adour (2014-2015). Atualmente, é professor do Departamento de Geografia/FFLCH/USP e orientador junto ao Programa de Pós-graduação em Integração da América Latina (PROLAM/USP). E-mail: jcsuzuki@usp.br. 
METODOLOGIAS ATIVAS E FORMAÇÃO CONTINUADA DE PROFESSORES: REFLEXÕES SOBRE A PRÁTICA DOCENTE EM GEOGRAFIA.........................................................................12

Janiara Almeida Pinheiro Lima

ALFABETIZAÇÃo CARTOGRÁficA ATIVA: UMA PROPOSTA COSNTRUTIVISTA PARA O USO DE MAPAS NO ENSINO FUNDAMENTAL I. .26

Guilherme Aparecido de Godoi

Francismara Neves de Oliveira

ESCALAS CARTOGRÁFICAS MEDIANDO A REPRESENTAÇÃO DAS RELAÇÕES ESPACIAIS NO ENSINO DE GEOGRAFIA......................40

Éderson Costa Briguenti

Maurício Compiani

ENSINO DE GEOGRAFIA E NOVAS TECNOLOGIAS:

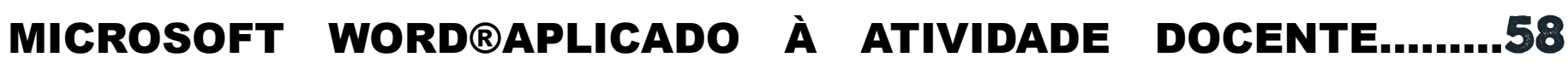

Camila Araujo Gomes Medeiros

Rafael Reis Bacelar Antón

Oriana Araujo

METODOLOGIA ATIVA: A HISTÓRIA EM QUADRINHOS COMO RECURSO PEDAGÓGICO NO ENSINODE GEOGRAFIA...................68

Mateus Francisco Lopes

Angélica Vieira de Souza-Lopes 
“LUGAR”, UM APORTE TEÓRICO-METODOLÓGICO PARA O ENSINO

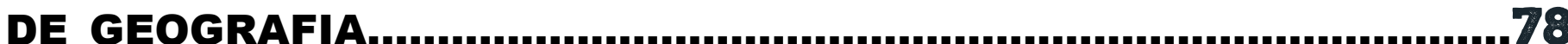

Rafael Ribeiro dos Santos

Maria Idelma Vieira D’Abadia

Loçandra Borges de Moraes

Mary Anne Vieira Silva

O USO DA IMAGEM VISUAL COMO ARTEFATO DIDÁTICO-PEDAGÓGICO PARA AS AULAS DE GEOGRAFIA. 94

Ricardo Santos de Almeida

Raphael Fontes Cloux

JOGOS DIDÁTICOS NO ENSINO DE GEOGRAFIA: O TERRITÓRIO MUNDIAL EM DISPUTA. 105

Gabriel de Miranda Soares Silva

TRILHA GEOGRÁfICA MUSICAL PARA O ENSINO DE GEOGRAFIA AGRÁRIA. 118

Maria José Costa Fernandes

LUZ, CÂMERA, AÇÃO: A PRODUÇÃO AUDIOVISUAL COM TECNOLOGIAS DIGITAIS DE INFORMAÇÃO E COMUNICAÇÃO (TDICS) COMO METODOLOGIA ATIVA NA EDUCAÇÃO GEOGRÁFICA. 131

Luiz de Vasconcellos Ferreira Sobrinho

Rosemy da Silva Nascimento

O PROCESSO de AVALIAÇÃo No ESTÁGIO SUPERVISIONADO EM ENSINO DE GEOGRAFIA. 148

Fábio Ferreira Santos 
RECURSOS DIDÁTICOS NO PROCESSO DE ENSINO E APRENDIZAGEM DE GEOGRAFIA

\section{Alisson Henrique Bavaresco}

GEOGRAFIA, ESPORTE E EDUCAÇÃO: NOVAS PRÁTICAS DE ENSINO A PARTIR DO FUTEBOL

Fernanda Serafim Alves

Gilvan Charles Cerqueira de Araújo

A ESCOLA COMO ESPAÇO dE REGULAÇÃO DO ALUNADO:UMA ABORDAGEM TEÓRICA EM TORNO DO GÊNERO E PROPOSIÇÕES DE AÇÃO 188

Gustavo Henrique Camargo Eufrásio

Carmem Lúcia Costa

FORMAÇÃO DE CONCEITOS DE APRENDIZAGEM GEOGRÁFICA POR ALUNOS COM TRANSTORNOS DO ESPECTRO AUTISTA: ÊNFASE NA MEDIAÇÃO DO PROCESSO. 198

Sandra Mara Soares Ferreira

Mauricio Compiani

ABP, CAMINHOS E POSSIBILIDAdES PARA O ENSINO DE GEOGRAFIA

Carlos Vinicius Antunes Rufini

Carlos Henrique Costa da Silva

O QUE A COPA DO MUNDO DE FUTEBOL TEM A VER COM O ENSINO DE CARTOGRAFIA?.

Joseane Carina Borges de Carvalho

Maurício Compiani 
O USO DO COMPUTADOR NA ESCOLA PÚBLICA: A UTILIZAÇÃO DA PLATAFORMA SCRATCH NO ESTUDODA NATUREZA

Juliana Andrade Moura

PATRIMÔNIO AMBIENTAL E CULTURAL: METODOLOGIAS ATIVAS E ESTRATÉGIAS DIDÁTICO PEDAGÓGICAS NO ENSINO DE GEOGRAFIA

Tiago Fernandes Rufo

Gilvan Charles Cerqueira de Araújo

A EXTENSÃo COMO METOdologia ATIVA dialógica No ENSINo DE GEOGRAFIA EM CENTROS SOCIOEDUCATIVOS

276

Dimitri Silva Sobral

PROPOSTA DE SEQUÊNCIA DIDÁTICA PARA O ENSINO DE GEOGRAFIA: ATMOSFERA TERRESTRE.

290

Fernando Camillo Santos Cano

A LINGUAGEM DOS QUADRINHOS NA SALA DE AULA:ENSINAR E APRENDER GEOGRAFIA COM AS HQS. 305

Vinício Luís Pierozan

Vanessa Manfio

AS PERCEPÇÕES DOS PROFESSORES DE GEOGRAFIA EM RELAÇÃO ÀS REFORMAS CURRICULARES DO ENSINO MÉDIO. 320

Matheus Henrique de Assis Reis

NOVAS TECNOLOGIAS EM AULAS DE GEOGRAFIA NO IFSP-CAPIVARI.

Thalia Carla Campos

Júlio César Suzuki 


\section{INTRODUÇÃo}

As metodologias ativas têm sido evidenciadas como importantes ferramentas didático-pedagógicas para os processos de ensino-aprendizagem, em diferentes contextos educacionais. Para o ensino de Geografia, elas podem colaborar para um entendimento do "espaço vivido, percebido, imaginado e concebido", conforme nos aponta Katuta (2011).

No entanto, o propósito e os saberes acerca das metodologias ativas nem sempre estão ao alcance dos professores que, na sua labuta diária, inserem-se num contexto de sobrecarga de trabalho e afazeres burocráticos que, por vezes, os despem do tempo necessário a novas aprendizagens e a busca por formação e autoformação.

Assim, os espaços destinados a formação continuada em serviço passam a ser importantes espaços formativos, de diálogo e reflexão docente, bem como, lugares de acolhida e protagonismo do professor acerca de sua prática e dos seus pares.

Desse modo, entender a formação continuada na perspectiva de acolhimento, mas também de reflexão, proporciona um espaço do pensar, e porque não, do aprender e discutir novos fazeres docentes.

Nessa perspectiva, as formações continuadas precisam ser pensadas a partir do trabalho docente e para valorização deste (MARIN, 1995; SILVA, 2019), entendendo que este representa uma importante prática social que, por meio da educação, cria possibilidades de desenvolver o raciocínio geográfico-espacial e reflexão crítica a todos os sujeitos envolvidos na ação didático-pedagógica.

Considerando o Currículo de Pernambuco, a formação continuada de professores é enunciada como um importante momento para o profissional em exercício, pois

Tais processos devem a ir ao encontro do perfil de professor do contexto atual em que se observam mudanças sociais, culturais, tecnológicas, econômicas, entre outras, as quais demandam profissionais com competências que extrapolam o ato de "transmitir" conteúdos que estejam abertos às inovações e às constantes aprendizagens, que respeitem as diversidades, que construam a partilha e o diálogo com seus pares, com seus estudantes, bem como com os demais agentes educativos, e que sejam voltados para a construção de um conhecimento holístico (PERNAMBUCO, 2019, p.30).

Coadunando com este pensamento, trazer as metodologias ativas para as formações continuadas de Geografia, num contexto de aulas remotas, durante a pan- 
demia da Covid-19, foi estratégico. Pois que, buscou-se extrapolar a relação didático-pedagógica vertical estimulando uma construção horizontal do conhecimento, por meio da inserção de aparatos que permitissem ao professor pensar sua prática, nas salas virtuais e presenciais, de forma colaborativa e engajadora tanto para eles quanto para os estudantes.

Nesse contexto, o presente trabalho teve como objetivo principal dialogar sobre as metodologias ativas e a prática docente em Geografia a partir do contexto das formações continuadas, tendo como cenário as relações didático-pedagógicas contemporâneas e os desafios profissionais relativos a prática docente.

Foi desenvolvido com 42 professores de Geografia da rede estadual de ensino de Pernambuco, vinculados a Gerência Regional Recife Norte, durante as formações continuadas que ocorreram entre agosto e outubro de 2020.

Nessas formações foi realizado, virtualmente, um minicurso intitulado "Metodologias Ativas para o Ensino de Geografia", composto de quatro módulos, onde puderam ser explorados os conceitos de metodologias ativas, bem como algumas das metodologias ativas mais conhecidas e que dialogassem com o cenário escolar no contexto pandêmico em que os professores estavam envolvidos.

Após o minicurso, foram aplicados questionários on-line com os participantes, elaborados no Google Forms, acerca das percepções sobre o uso das metodologias estudadas nas formações, em sua prática docente em Geografia.

A escolha por fazer esse trabalho junto com os professores levou em consideração que as metodologias ativas dialogam com as normatizações vigentes na Educação Básica, em especial com o Currículo de Pernambuco, podendo ser exploradas de diversas maneiras pelos professores, em espaços educacionais diversos e sob a égide da Geografia escolar e seus desdobramentos.

Considerou-se também que nem todos os docentes conhecem sobre metodologias ativas e quando são conhecidas o uso esbarra em inúmeras provações, dentre elas o receio de usá-las e de consequentemente vencer os paradigmas instituídos. 


\section{METOdOLOGIAS ATIVAS E PRÁtICA DOCENTE}

As metodologias ativas na educação não são algo novo. De acordo com Bacich \& Moran (2018, p. xv) "O estudo sobre a inserção de metodologias ativas na educação, não é recente". Porém, estas têm sido evidenciadas como tendência de práticas pedagógicas inovadoras nos últimos anos e situam-se como referências de quebras de paradigmas quando sugerem uma mudança na dinâmica do espaço de ensino-aprendizagem e desafiam que o foco central da aprendizagem seja agora o estudante, e não mais o professor "ensinador".

Desse modo, é preciso conceber em que espaço-tempo essa temática foi inicialmente enunciada. Conforme apontam Mota e Werner da Rosa (2018), foi a partir de 1980 que as metodologias ativas passaram a ser uma tentativa de dinamizar o processo de aprendizagem, para que os estudantes fossem imersos em ambientes que promovessem a sua proatividade, instigando a comunicação e a investigação, a partir da ação destes sujeitos.

Nesse sentido, as metodologias ativas, inicialmente, representam uma oposição a métodos e técnicas enraizados na transmissão de conhecimentos, configurados como tradicionais. Contudo, o propósito não é substituir um modelo pelo outro e sim fomentar espaços mais interativos de aprendizagem proporcionando a diversificação no processo de ensinagem em cada contexto socioeducativo.

De forma objetiva, Bonwell e Eison (1991) e Silberman (1996) explicam que as metodologias ativas funcionam como oportunidades de estabelecer uma relação de diálogo entre professor e estudante, onde, a este, é oportunizado, durante as aulas e situações didáticas, examinar e refletir sobre o que sua participação pode inferir em tudo que está sendo feito.

Tommasini (2017) ratifica o conceito de metodologias ativas afirmando que elas representam também o processo no qual o estudante está diretamente envolvido na sua aprendizagem e o professor passa a ser um facilitador da aprendizagem e não mais o detentor absoluto do conhecimento a ser transmitido. Corroborando com ele tanto estudante quanto professor estabelecem um elo colaborativo e de horizontalidade no processo de ensino-aprendizagem.

Logo, a prática docente frente ao cenário embebido em metodologias ativas 
move-se numa dança articulada entre saberes epistemológicos, práticas pedagógicas, humildade e colaboração. Ao mesmo tempo em que este balé deslancha, a face da aprendizagem ativa vai tomando corpo nas relações didático-pedagógicas estabelecidas em bases de parceria entre professores e estudantes e fortalecidas pelo diálogo.

Nesse contexto, concordando com Gomes (2010), reconhece-se que o campo de conhecimento dos estudantes é ampliado a partir do uso das metodologias ativas, pois, estas os instigam a pensar criticamente, tomar decisões e agir de forma autônoma, o que não ocorreria sem as provocações e mediação didática do professor.

A habilidade em tornar interessantes os diferentes conceitos e temas, despertando a curiosidade epistemológica (FREIRE, 2007) nos estudantes, transborda em uma relação interpessoal de amorosidade e ao mesmo tempo de provocações dialógicas com os sujeitos envolvidos na ação pedagógica.

Nesse sentido, Valente et al (2017) realçam que as metodologias ativas e a aprendizagem ativa por vezes podem ser confundidas. Mas, como todo ato de aprender requer que o sujeito seja ativo, percebem que o uso do termo aprendizagem ativa é redundante, pois, a ação está intrínseca ao ato de aprender. Assim, enunciam que as metodologias ativas, são aquelas cuja característica principal refere-se ao fazer do estudante, a construção protagonista do saber e ao aprender fazendo remetendo a ideia de atividade do sujeito no processo de ensino-aprendizagem.

Sobremaneira, pensar as metodologias ativas como importantes veículos de estímulo a aprendizagem, de forma a desafiar os estudantes a refletirem sobre sua condição cidadã e o contexto socioespacial em que estão inseridos, é que também podemos pensar a prática docente como ferramenta de igual importância, para que tais estímulos e desafios possam ser alcançados e superados.

Desse modo, pensar a Geografia enquanto prática de leitura e compreensão do espaço, a partir do uso de metodologias ativas presentes na ação didático-pedagógica docente, faz alavancar a ideia de que o estudo do espaço Geográfico e suas diferentes nuances e faces pode constituir em uma bagagem essencial para leitura de mundo que os estudantes podem ser provocados a desenvolver.

Nesse sentido, Gemignani (2012) corrobora conosco enunciando que as metodologias ativas, estimulam os sujeitos a construir o conhecimento por meio de reso- 
lução de problemas, desafios, pesquisas, provocando o estudante a colocar-se numa postura ativa e reflexiva acerca dos conteúdos e conceitos enunciados, bem como de sua própria postura social.

Pensando nisso, concatenando as ideias a partir do que enunciam Bacich \& Moran (2018) e os autores supracitados, ressalta-se a importância do professor e seu papel no cenário educativo, pois que, é impossível segregar a mediação do professor e a aprendizagem ativa do estudante, pois, uma coisa conecta-se a outra intrinsecamente.

O papel do professor enquanto mediador do conhecimento, tutor da aprendizagem, curador dos veículos formativos e informativos, suscita que ao ajudar os estudantes a nortear os caminhos de suas aprendizagens, o mesmo leva em consideração suas individualidades e ritmos de aprendizagem, respeitando-os.

É esta a referida personalização da aprendizagem, que não requer do professor mais trabalho do que o mesmo já desempenha cotidianamente, mas, em contrapartida, exige do mesmo maior sensibilidade em oportunizar diferentes maneiras de abordar e provocar os estudantes, buscando estimula-los em suas diferentes percepções e inteligências.

Nessa perspectiva, a importância do docente ressignificar a sua prática e discorrer outro olhar acerca das formas centralizadoras de ensino, tão presentes no fazer docente tradicional e mediocrizado pela descontextualização com a realidade do discente, precisam ser revistas, só por comporem um arcabouço de saberes que dialogam com as latências educacionais contemporâneas, mas, porque a prática docente reflexiva extrapola tais tendências, enquanto se respalda em compromisso social inerente a profissão.

\section{A formação continuada e A REFlexão sobre O USO de METODOLOGIAS ATIVAS NO ENSINO DE GEOGRAFIA}

O ensino de Geografia e a própria Geografia escolar, inserem-se no contexto problematizador da realidade socioespacial em que se encontra a escola e a comunidade escolar.

Conforme Gurgel e Silva (2016, p.10) "Para se chegar à sala de aula, o saber científico precisa ser tangenciado por métodos didáticos pedagógicos que façam essa 
adequação, pensando no que se ensina, como se ensina e para quem se ensina".

Corroborando com o pensamento de Gurgel e Silva (2016), Macêdo e Lima (2019, p.2), expõem que

para que a Geografia escolar possa contribuir efetivamente para uma formação plena da cidadania do estudante, precisa ser ensinada a partir de uma proposta pedagógica que esteja aberta a atividades e técnicas que os levem à discussão, à formação de ideias, rompendo com a passividade e a concepção de professor transmissor de conteúdos. Nesse sentido, compreende-se que a postura do docente assume um novo papel, o de auxiliador dos alunos na construção dos seus conhecimentos.

É inegável que, nesse contexto, evocar a reflexão sobre a importância do professor promover várias maneiras de ensinar, considerando que esses modos de ensinar precisam partir da sensibilidade e conhecimento da realidade escolar em que está inserido, torna-se fundamental como atitude didático-pedagógica para poder inovar a prática docente.

Pensando no fazer docente em Geografia, espelhado nas diferentes salas de aula em que esta ciência é erigida, foram realizadas formações continuadas com professores de Geografia da rede estadual de ensino em Pernambuco, vinculados a Gerência Regional Recife Norte, acerca do uso das metodologias ativas considerando a reflexão sobre os contextos educativos em que se inseriam.

Nessa perspectiva, foi realizada uma pesquisa com os participantes das formações, onde aplicaram-se questionários on-line com 42 professores que lecionavam Geografia nesta regional, a partir das formações continuadas oferecidas no segundo semestre de 2020. A pesquisa foi realizada no período pandêmico, logo, foi considerado esse aspecto também.

Pernambuco decidiu inicialmente estabelecer o ensino remoto, e com o passar do tempo e das demandas emergentes, estabeleceu o ensino híbrido como alicerce das ações educativas no estado, nesse contexto pandêmico. Por isso, é importante destacar esse cenário, a fim de contextualizar o porquê das escolhas e ações desenvolvidas nas formações continuadas em Geografia.

Conforme os dados coletados nas formações, o Gráfico 1, retrata como os professores de Geografia percebem o uso das metodologias ativas para práticas pedagógicas cotidianas e a possibilidade de usá-las ou não. 
Gráfico 1- Metodologias ativas e prática pedagógica em Geografia

\section{Como você vê o uso de Metodologias Ativas para a prática pedagógica em Geografia?}

\section{2 respostas}

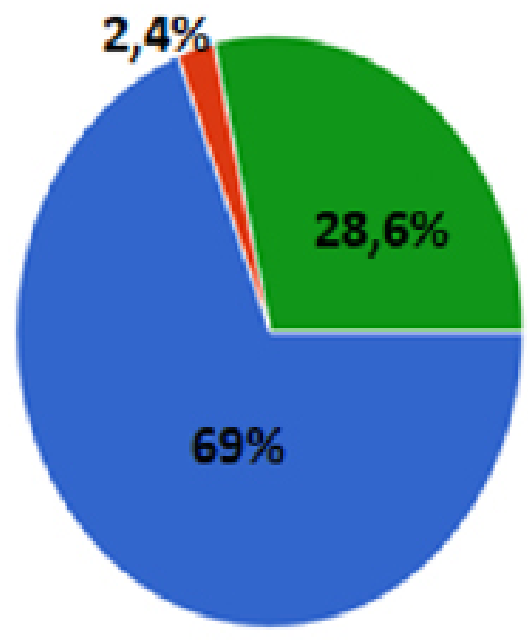

Possivel de executar

Dificil de executar

Impossivel de executar

Importante de se executar

Fonte: A autora (2020).

A partir do Gráfico 1 é possível perceber que, diante das formações continuadas os professores indicaram que o uso de metodologias ativas para a prática docente em Geografia é possível de ser executada conforme $69 \%$ dos respondentes, é importante de se executar de acordo com $28,6 \%$ dos participantes e é difícil de executar conforme $2,4 \%$ dos docentes. Nenhum docente informou ser impossível de executar as metodologias ativas para a prática pedagógica em Geografia.

O que demonstra que os docentes estão abertos a mudanças e a trabalhar de forma mais colaborativa com os estudantes vencendo o tradicionalismo e ressignificando o seu fazer docente.

Em sequência, foi perguntado aos docentes sobre que metodologias ativas, dentre as que estudamos e debatemos nas formações continuadas, para que indicassem quais delas poderiam ser usadas por eles em suas aulas de Geografia. Conforme demonstra o Gráfico 2, os professores responderam que: 
Gráfico 2- Metodologias ativas apresentadas nas formações e uso nas aulas de Geografia por professores da GRE- Recife Norte

Você usaria alguma dessas Metodologias Ativas estudadas nas formaçōes continuadas de Geografia na sua prática docente?

42 respostas

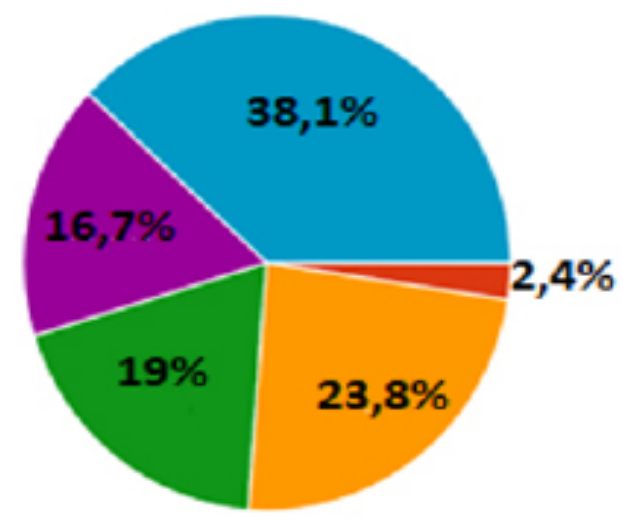

STORYTELLING

gamificação

SALA DE AULA INVERTIDA

APRENDIZAGEM BASEADA EM PROJETOS

APRENDIZAGEM BASEADA EM PROBLEMAS

TODAS

Fonte: A autora (2020).

Usariam todas as metodologias ativas apresentadas nas formações continuadas em suas aulas de Geografia, correspondendo a $38,1 \%$ do total de respondentes. Em segundo lugar, com $23,8 \%$ foi elencada a sala de aula invertida, seguida da aprendizagem baseada em projetos com 19\%, aprendizagem baseada em problemas com $16,7 \%$ e a gamificação foi a metodologia ativa que os professores menos se identificaram para usá-las em suas aulas, correspondendo a $2,4 \%$ e o Storytelling não foi mencionado de forma específica.

O Gráfico 2 traz uma perspectiva interessante pois que, permite observar que as metodologias ativas mais ligadas ao lúdico foram as que professores menos se propuseram a usar em aulas de Geografia.

Em contrapartida a sala de aula invertida, a aprendizagem baseada em projetos e aprendizagem baseada em problemas, compuseram um importante cenário frente as perspectivas dos professores, apontando também uma aproximação maior com as realidades vividas.

A gamificação, sendo uma das que menos os envolveu, nos leva a pensar que, diante da maioria dos docentes não serem nativos digitais ${ }^{2}$, não conseguiram criar identidade com esse instrumento. 
Contudo, a partir desse gráfico, é preciso refletir sobre o que propomos em sala de aula, pois que, o que é interessante da perspectiva do professor, nem sempre é enxergado pelos estudantes da mesma maneira. Logo, é preciso que o professor faça o movimento de propor e não de impor sua vontade, bem como, de se lançar a aprender também com os estudantes, num movimento de colaboração e humildade.

Dando continuidade e considerando o contexto pandêmico que mudou a face da Educação em diferentes escalas, perguntou-se aos docentes acerca das metodologias ativas no contexto do ensino híbrido, uma vez que, essa proposta foi lançada pelo governo de Pernambuco como alternativa para minimizar os problemas gerados pela pandemia, no cenário da educação, neste estado.

O Gráfico 3 aponta o entendimento dos docentes em relação as metodologias ativas e seu papel diante do cenário do ensino hibrido em que foram inseridos. Assim, é possível notar que:

\section{Gráfico 3- Metodologias ativas no contexto do Ensino Híbrido}

\section{Você acredita que as Metodologias Ativas podem ajudar na construção das ações pedagógicas no contexto do Ensino Hibrido? \\ 42 respostas}

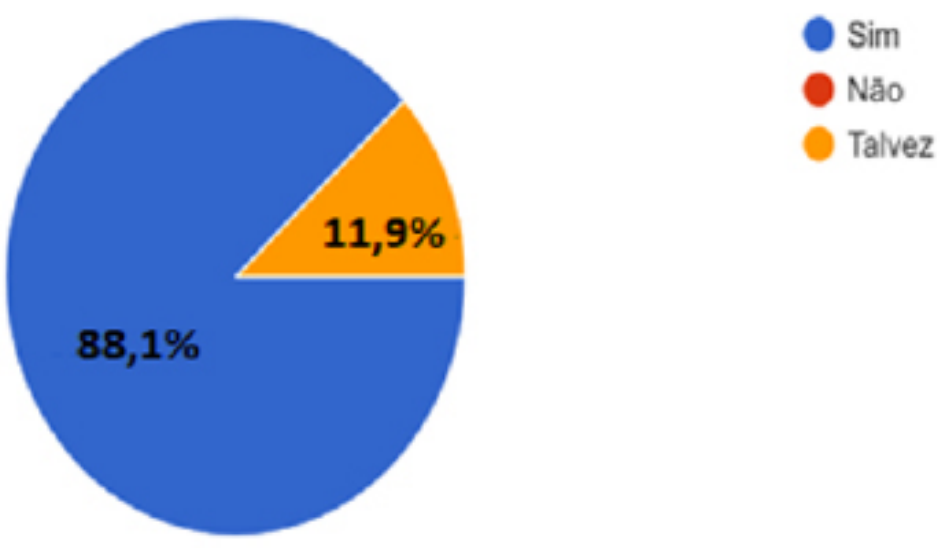

Fonte: A autora (2020).

Considerando o contexto do ensino híbrido, $88,1 \%$ dos professores de Geografia consideram que as metodologias ativas podem ajudar no desenho de suas ações pedagógicas para o ensino de Geografia. E, 11,9\% acreditam que talvez as metodologias ativas possam contribuir. Confirmando que os mesmos veem as metodologias ativas como aliadas no processo de ensino-aprendizagem, uma vez que ninguém 
respondeu que não.

Desse modo, com a análise dos dados coletados nesta pesquisa, é possível notar, que os professores de Geografia enxergam nas metodologias ativas possibilidades de alavancar suas aulas e criar novas oportunidades de ensino. Demonstram estar dispostos a usar as metodologias ativas experienciadas nas formações continuadas em seu cotidiano escolar.

Contudo, um dado acerca desse cenário chama atenção, pois que as metodologias ligadas a ludicidade, como a gamificação e o Storytelling, não tiveram tanta adesão por parte dos docentes. Daí, surge um questionamento, porque será que algo tão atraente aos discentes, não foi tão bem recepcionado pelos docentes, a ponto de se esquivarem desse uso em sala de aula?

Uma das possíveis respostas ao questionamento, fazendo uma autoavaliação da formação que ministrei, pode ser a maneira como essa metodologia ativa foi apresentada na formação continuada, tornando o entendimento do professor difuso nesse aspecto. Outra resposta dialoga com as aptidões e desafios que trabalhar com a gamificação e o Storytelling apresentam.

Contudo, é importante esclarecer sobre a gamificação que esta não consiste necessariamente na criação de jogos com fins educacionais pelos professores, e sim, em usar elementos de games como: recompensas, desafios, trilhas, por exemplo, a fim de promover o engajamento estudantil nas aulas. Bem como, o Storytelling não representa uma caricatura ou uma infantilização do fazer docente ou do tratamento dos diferentes conteúdos, conceitos e temas.

O contrário disso, são elementos que podem exprimir maturidade dos discentes e desenvolver cooperação ao invés de competição, criatividade ao invés de morosidade e divertimento o que favorece e torna atraentes as aulas, de Geografia e de qualquer outro componente curricular.

Por fim, merece destaque que a partir dos dados da pesquisa pode-se notar que os professores de Geografia da GRE Recife Norte estão abertos a inovação e a experimentar fazer uso de metodologias ativas, para uma aprendizagem significativa do estudante em diferentes contextos. 
Refletindo sobre esse trabalho é possível notar que, embora façam parte de um contexto de incertezas e mudanças pedagógicas em trânsito, as metodologias ativas representam um importante subsídio para a prática docente e para o ensino de Geografia.

Percebe-se também que a formação continuada em exercício, seja ela institucional ou não, é um espaço de troca de saberes e aprendizagens docentes, que ocorrem mutuamente e colaboram para o fortalecimento dos professores enquanto grupo e no que se refere a profissionalização colaborativa.

Notar que a formação continuada pode suscitar discussões e reflexões sobre a prática docente, a partir de pesquisas realizadas sobre o impacto que essas ações exercem sobre os profissionais inseridos no processo, pode contribuir tanto para a prática dos professores de Geografia quanto para a melhoria das formações oferecidas institucionalmente.

É preciso refletir também sobre a importância em colaborar para uma aprendizagem significativa do estudante (MOREIRA, 1999), onde, os conceitos, conteúdos e temas da Geografia possam fazer sentido em seus cotidianos, entendendo que o papel do professor como mediador e facilitador da aprendizagem é essencial nesse processo.

Contudo, para que as metodologias ativas possam fazer parte do fazer didáticopedagógico dos docentes, é preciso estimular a reflexão sobre a ação docente (SCHÖN, 2000), a pesquisa por alternativas condizentes com os diferentes contextos em que a escola e sua comunidade estão inseridas, mas também do olhar sensível do professor sobre si mesmo e sobre a importância social de sua práxis, estendendose ao contexto dos ministrantes de formação continuada.

\section{REFERÊNCIAS}

BERBEL, N. A. N. As metodologias ativas e a promoção da autonomia de estudantes. Semina: Ciências Sociais e Humanas, Londrina - PR, v. 32, n. 1, p. 25-40, jan./ jun. 2011. Disponível em:< http://www.proiac.uff.br/sites/default/files/documentos/ berbel_2011.pdf >. Acesso em: 19 set. 2019. 
FREIRE, P. Pedagogia da autonomia: saberes necessários a pratica educativa. 31 ed. São Paulo: Paz e Terra, 2007.

GEMIGNANI. E.Y.M.Y. Formação de professores e metodologias ativas de ensino aprendizagem: ensinar para compreensão. Fronteiras da Educação [on-line], Recife - PE, v.1, n.2, p.1-27, jan./jul. 2014. Disponível em:<http://www.fronteirasdaeducacao.org/index.php/fronteiras/article/view/14>. Acesso em: 21 set. 2019.

GOMES, A. P.; ARCURI, M.B.; CRISTEL, E.C.; RIBEIRO, R.M.; SOUZA, L.M.B.da M.; SIQUEIRA-BATISTA, R. Evaluation in medical education: the role of the portfolio in curricula based on active methodologies. Rev. bras. educ. med., Rio de Janeiro, v. 34, n. 3, p. 390-396, 2010. Disponível em:< http://www.scielo.br/pdf/rbem/v34n3/08. pdf>. Acesso em: 21 set. 2019.

GURGEL, T. C. N. P.; SILVA, C. N. M. Geografia acadêmica e geografia escolar: entorno de uma aproximação teórico-conceitual. III CONEDU - Congresso Nacional de Educação - Natal - RN. Realize Editora, 2016. Disponível em: <http://www. editorarealize.com.br/revistas/conedu/trabalhos/TRABALHO_EV056_MD1_SA3_ ID9769_14082016200213.pdf>. Acesso em: 17 mai. 2020.

KATUTA, A. M. Representação do espaço vivido, percebido, imaginário e concebido. Boletim de Geografia, v. 19, n. 2, p.179-186. 21 jul. 2011. Disponível em:< https:// periodicos.uem.br/ojs/index.php/BolGeogr/article/view/14088>. Acesso em: 16 out. 2019.

MACEDO, H. C. de e LIMA, J. A. P. L. O ensino da Geografia e estudo das questões socioambientais: abordagem para formação da cidadania. $4^{\circ}$ Congresso Nacional de Pesquisa e Ensino em Ciências - CONAPESC. Campina Grande- PB: Realize, 2019.

MARIN, A. Educação continuada: introdução a uma análise de termos e concepções. In: Cadernos CEDES, Campinas: Papirus, CEDES, n. 36, 1995.

MOREIRA, M. A. Aprendizagem significativa. Brasília: Editora Universidade de Brasília, 1999.

MOTA, A.; WERNER DA ROSA, C. Ensaio sobre metodologias ativas: reflexões e propostas. Revista Espaço Pedagógico, v. 25, n. 2, p. 261-276, 28 maio 2018. Disponível em:< http://seer.upf.br/index.php/rep/article/view/8161 >. Acesso em: 21 set. 2019.

PAULFREY, J.; GASSER, U. Nascidos na era digital: entendendo a primeira geração de nativos digitais. Porto Alegre: Grupo A, 2011. 
PERNAMBUCO. Secretaria de Educação e Esportes. Currículo de Pernambuco: ensino fundamental. Secretaria de Educação e Esportes, União dos Dirigentes Municipais de Educação. Recife: a Secretaria, 2019.

SCHÖN, D. Educando o profissional reflexivo: um novo design para o ensino e a aprendizagem. Porto Alegre: Artmed, 2000.

SILVA, E. S. Formação de professores e o uso das geotecnologias no ensino-aprendizagem de Geografia. João Pessoa-PB: UFPB, 2016. Disponível em: <https://repositorio.ufpb.br/jspui/handle/tede/8598>. Acesso em: 08 out. 2020.

TOMMASINI, P. O que é metodologia ativa?. Publicado em 5 de dez de 2017. 2017. Disponível em: <https://www.youtube.com/watch?v=9Ec3EM0X5UE>. Acesso em: 23 set. 2018.

VALENTE, J. A.; ALMEIDA, M. E. B.; GERALDINI, A. F. S. Metodologias ativas: das concepções às práticas em distintos níveis de ensino. Revista Diálogo Educacional [on-line]. n.17(52), p.455-478, 2017. Disponível em: <https://periodicos.pucpr.br/ index.php/dialogoeducacional/article/view/9900>. Acesso em: 22 set. 2019. 


\section{ALFABETIZAÇÁ CARTOGRÁFICA ATIVA: UMA PROPOSTA}

\section{COSNTRUTIVISTA PARA O USO DE MAPAS NO ENSINO FUNDAMENTAL $I$}

GUILHERME APAREGIDO DE GODOI FRANGISMARA NEVES DE OLIVEIRA
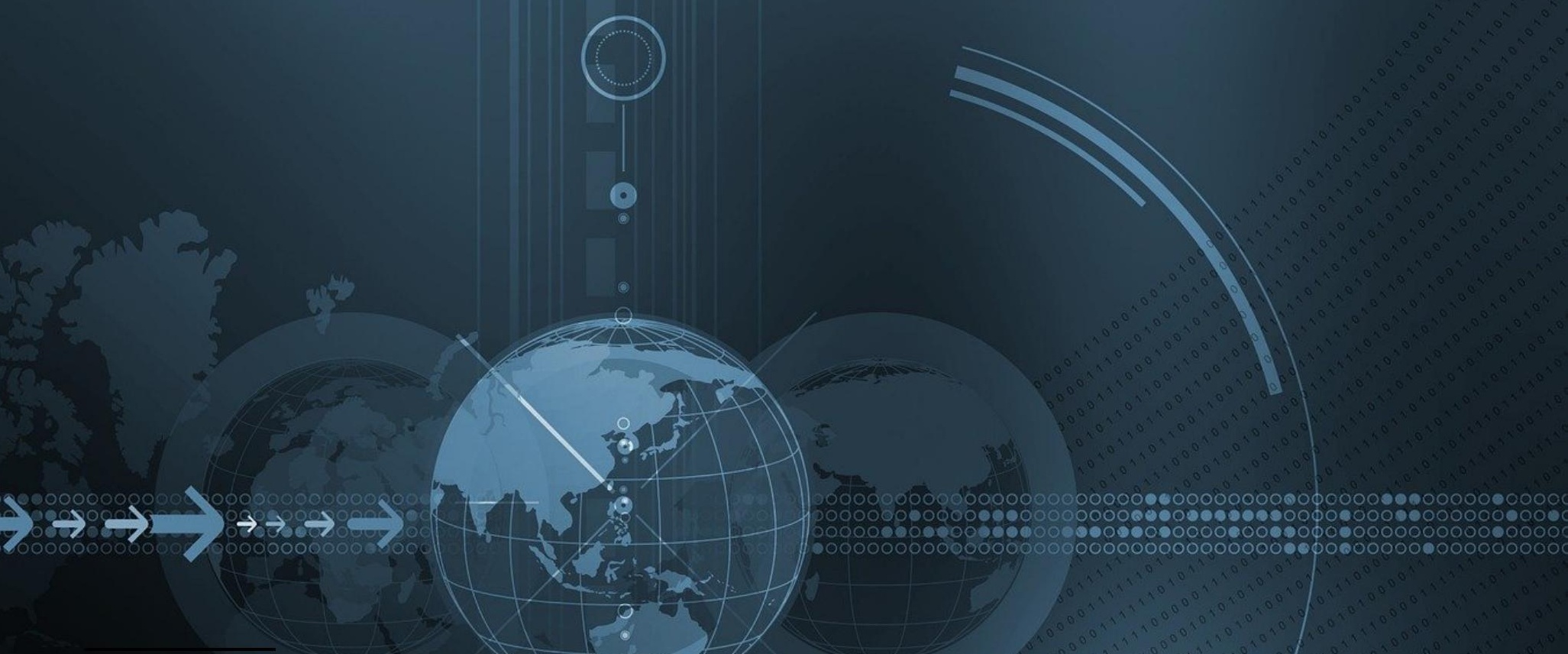

1 Doutorando em Educação pela Universidade Estadual de Londrina, graduado em Geografia (bacharelado e licenciatura) pela UNICAMP, guilhermeapgodoi@gmail.com

2 Docente do Programa de Pós-Graduação da Universidade Estadual de Londrina, Pós-doutorado em Psicologia da Educação pelo Instituto de Psicologia - USP e em Educação pela Universidade Norte-Paranaense, francis.uel@gmail.com 


\section{INTRODUÇÃO}

O mapa é um importante instrumento para se representar graficamente o espaço geográfico, para Castrogiovanni e Costella (2012, p. 7), os mapas "traduzem o espaço geográfico em forma de síntese". Interpretar um mapa vai além de uma simples identificação dos seus limites, cores ou signos. Sua leitura possibilita a compreensão da realidade socioespacial e dos processos envolvidos na constituição dos lugares. São assim, portadores de conteúdos potentes para ressignificar a ação da sociedade na natureza e entre as próprias pessoas, umas com as outras.

No contexto escolar o uso do mapa assume grande importância para o ensino e aprendizagem dos saberes geográficos. No entanto, com frequência sua utilização fica restrita a uma simples cartografia da localização, apenas para ilustrar determinado conteúdo do livro didático. Este uso formal dos mapas não contribui para a elaboração e compreensão significativa da linguagem cartográfica e os saberes possíveis não são alcançados, configurando um analfabetismo cartográfico. Concordamos com Oliveira (2014) ao dizer que o que ocorre é um ensino "pelo mapa" e não "do mapa".

Para a leitura de um mapa é necessário um processo de abstração no qual o aluno compreenda que o plano bidimensional da produção cartográfica representa o espaço em que vivemos e enxergamos tridimensional. Para tanto, torna-se fundamental a construção de determinadas noções espaciais, dentre as quais destacam-se a compreensão da visão vertical, pois é sob está perspectiva que o espaço real é representado dentro de uma percepção plana. A métrica e a proporção são noções fundamentais para a compreensão da escala. Já outras noções como a de vizinhança, separação e ordem, relacionam-se com a posição dos elementos no mapa e influenciam a localização espacial. Desta forma, consideramos que para um aluno compreender as projeções, formas, linhas, símbolos, escala e demais elementos que configuram um mapa, ele deve ter construído cognitivamente noções espaciais fundamentais para realizar a interpretação gráfica.

Piaget em parceria com Barbel Inhelder escreveu o livro "A representação do espaço na criança" o qual reúne experimentos e discussões sobre a gênese e o desenvolvimento do espaço intelectual. Segundo os autores, são as relações 
topológicas, projetivas e euclidianas que constituem o espaço representativo (PIAGET; INHELDER, 1993). Tendo adotado essa compreensão, o presente ensaio teórico objetivou relacionar os aspetos cognitivos envolvidos na representação do espaço na criança com a alfabetização cartográfica, no sentido de possibilitar a construção de conhecimentos cartográficos e geográficos no Ensino Fundamental I.

\section{A ALFABETIZAÇÃO CARTOGRÁFICA NO ENSINO FUNDAMENTAL I}

Segundo a BNCC - Base Nacional Curricular Comum (BRASIL, 2017) os saberes da cartografia estão presente desde os primeiros anos do Ensino Fundamental I (E. F. I). O mapa é uma representação codificada do espaço real e a alfabetização cartográfica prepara o aluno para realizar sua leitura. Os mapas possuem um sistema semiótico com base em uma linguagem específica, trata-se da linguagem cartográfica, que utiliza signos (legenda), reduções (escala) e projeções para a codificação gráfica do espaço. Ler um mapa significa decodificar e representar mentalmente sua informação. O processo de alfabetização cartográfica abrange tanto o aprendizado da linguagem própria da cartografia, como também é indispensável produzir significados aos dados presentes nos mapas, conforme Castrogiovanni e Costella (2012, p.14):

Ler o mundo, ou as representações dele, requer um exercício constante no estabelecimento de relações para que ocorram as (re) significações. A este exercício chamamos de alfabetização. Quando pensamos que a criança, no início de sua vida estudantil, substitui um conjunto de letras por um significado real, e, consequentemente num processo contínuo de descobertas aprender a dar significados aos símbolos de um mapa, por exemplo, estará desenvolvendo uma linguagem própria, com isto, demonstra estar no processo contínuo de alfabetização.

Para a alfabetização cartográfica torna-se necessário estruturas do pensamento que possibilitem ao sujeito construir conhecimento aceca das linguagens e saberes cartográficos. Nesse sentido, o aprendizado dos conceitos deve estar alinhado ao desenvolvimento cognitivo das noções espaciais topológicas, projetivas e euclidianas. 


\section{A REPRESENTAÇÃO DO ESPAÇO NA CRIANÇA}

As relações espaciais são construídas primeiramente no campo perceptivo (período sensório-motor ${ }^{3}$ ) e servem de apoio para a reconstrução que ocorre no campo representativo. Piaget aponta que o bebê por volta dos 5 meses começa a construir suas primeiras relações espaciais através de sua atividade sensóriomotriz. No entanto a representação do espaço só é possível a partir da aquisição da função simbólica (período pré-operatório), que tem início por volta dos 2 anos, contemporâneo ao desenvolvimento da linguagem e do sistema de signos coletivos. Com base nas conquistas do espaço perceptivo ocorre uma reconstrução das relações espaciais só que agora no campo cognitivo (pensamento) e tal processo envolve uma série de ações e movimentos do sujeito na tomada de consciência da configuração do seu campo espacial. Conforme Piaget e Inhelder (1993, p.58):

o sujeito não consegue reconhecer e, sobretudo, se representar a não ser as formas que é capaz de reconstruir graças às suas próprias ações, efetuandose, pois, a 'abstração' da forma a partir da coordenação das ações e não, ou não somente do objeto.

A coordenação do campo espacial é elaborada progressivamente a partir da ação do sujeito sobre o objeto, envolve o processo de interação com seu o meio físico e social. Os pressupostos piagetianos revelam que somente a percepção das noções espaciais não basta para que também se realize pensamentos sobre o espaço. $O$ espaço intelectual é uma construção que envolve a ação do sujeito que conhece. As conquistas do espaço perceptivo servem de apoio para as operações mentais que o sujeito aciona no processo de representação do espaço. A Figura 1 reúne as principais características envolvidas no processo da representação do espaço.

3 Piaget definiu quatro estádios (períodos) que marcam a consolidação construtiva do conhecimento, as idades são consideradas como aproximadas: Sensório-Motor (até 2 anos de idade); Pré-Operatório (entre 2 e 7 anos de idade); Operatório Concreto (entre 7 e 11-12 anos de idade); e Operatório Formal (a partir dos 11-12 anos de idade) (WADSWORTH, 1997). 
Figura 1: As relações topológicas, projetivas e euclidianas

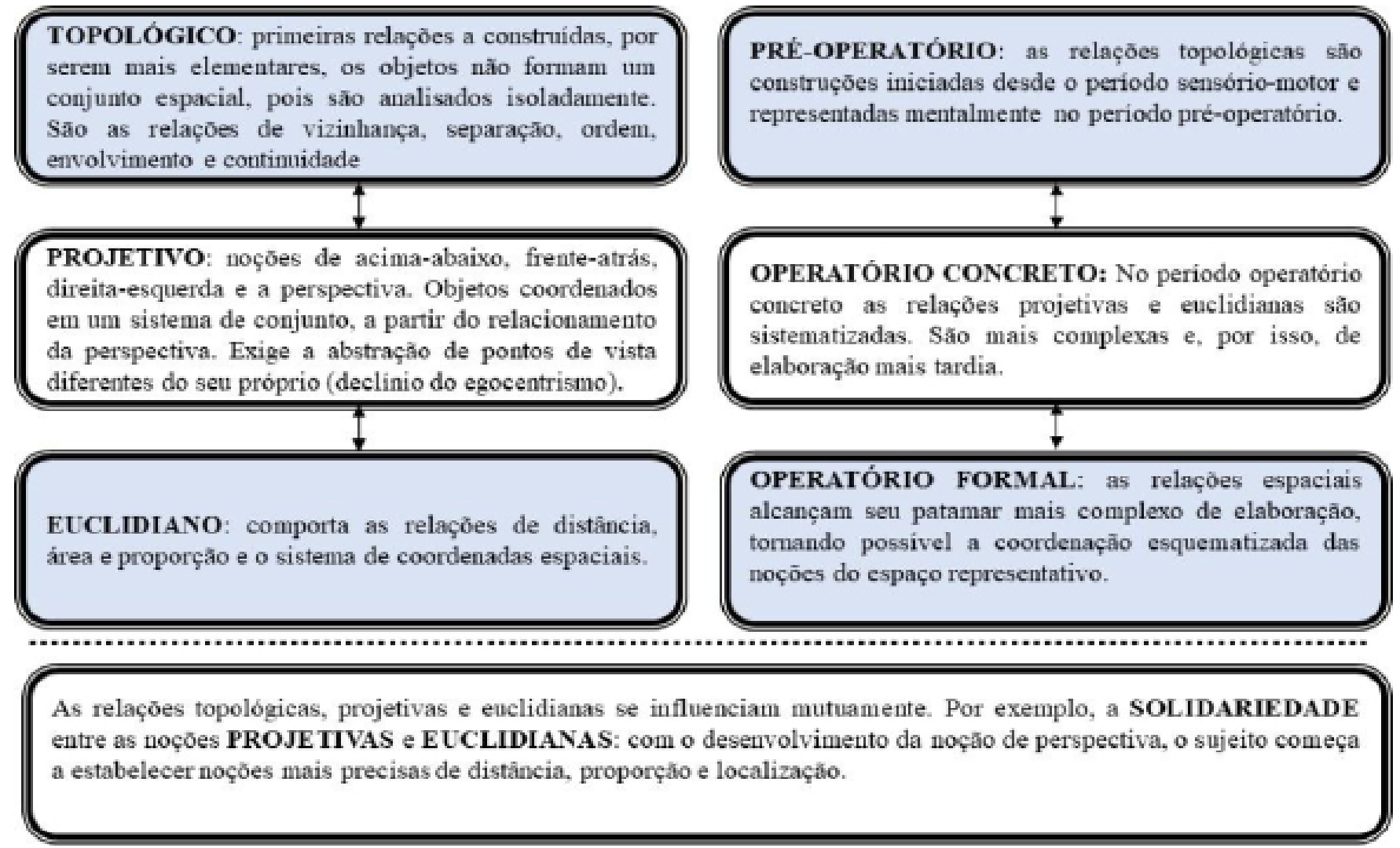

Fonte: GODOI et. al, 2021a, p. 25001.

As relações do espaço topológico são de complexidade menor e por isso são as primeiras que o sujeito constrói durante o período pré-operatório. Compreendem as relações de vizinhança, separação, ordem, envolvimento e continuidade. A partir das relações topológicas são construídas as noções do espaço projetivo e euclidiano, são relações mais complexas e por isso de elaboração posterior. As relações projetivas e euclidianas apoiam-se nas conquistas do espaço topológico, pois é através da sistematização crescente das relações de vizinhança, separação, ordem, envolvimento e continuidade que a coordenação espacial se torna possível. As noções projetivas e euclidianas são possíveis a partir do pensamento operatório e relacionam-se com o declínio do egocentrismo, compreendendo o período operatório concreto (dos 7 aos 11 anos em média). É neste período que o espaço representativo se constitui em sua forma elementar, pois continuará progredindo no período das operações formais.

O espaço projetivo compreende a noção de perspectiva e suas correlatas como as noções de acima/abaixo, direita/esquerda e em frente/atrás. Sua construção envolve 
a coordenação dos objetos em um sistema de conjunto com base em determinado ponto de vista, seja do próprio sujeito ou do objeto. Mas este relacionamento ainda não considera as distâncias entre cada objeto, sua área e proporção. Estas noções são características do espaço euclidiano, conforme explica Viana (2015, p. 851):

\begin{abstract}
as relações euclidianas permitem localizar objetos em um sistema de referência e têm como base a noção de distância. Para tal construção, são necessárias a conservação de distância, de comprimento e superfície; a construção de medida em uma, duas ou três dimensões; a elaboração de um sistema de coordenadas para localização no plano e no espaço e as consequentes transformações geométricas (as que preservam comprimento e ângulo - translação, rotação, simetria - e as que preservam apenas ângulos - semelhanças).
\end{abstract}

A configuração do espaço euclidiano envolve o relacionamento de todos os objetos entre si, levando em conta suas posições e deslocamentos no campo espacial, bem como suas relações métricas. "Essa coordenação dos objetos, que supõe a conservação das distâncias, bem como a elaboração de deslocamento (ou transformação congruente das figuras do espaço), acaba na construção dos sistemas de referência ou de coordenadas" (PIAGET; INHELDER, 1993, p. 393). Esta seria a principal construção do espaço euclidiano, são as noções métricas de distância, proporção e área que possibilitam a construção de um campo espacial estruturado e coordenado. De acordo com Piaget e Inhelder (1993, p. 433) "é somente a partir de 1112 anos, isto é, no curso do estádio das operações formais, que verdadeiros sistemas convencionais de referência são construídos, permitindo julgar simultaneamente posições e distâncias".

Embora distintos, os espaços projetivo e euclidiano constituem-se correlativamente, um solidário ao outro. O espaço euclidiano, como aponta Paganelli (2014, p. 50) "não será possível sem a estruturação simultânea das relações projetivas: a conservação das distâncias e das superfícies implica, evidentemente, reciprocidade ou simetria das relações de perspectiva". É a partir da diferenciação crescente de pontos de vista que o espaço deixa de ser interior a cada objeto e passa a compreender um campo espacial, no qual apoiam-se as noções métricas para a estruturação em um sistema de coordenadas euclidiano. 


\section{AS RELAÇÕES ESPACIAIS E O ESPAÇO GRÁFICO}

Um dos meios que Piaget investigou a representação do espaço na criança foi por através dos desenhos, sejam eles cópias de figuras geométricas, desenhos espontâneos, ou desenhos a partir de modelos pré-definidos. Essa técnica parte do pressuposto que o sujeito ao desenhar, opera as relações espaciais que construiu até aquele momento. Desta forma, o desenho "permite [...] a constatação do caráter espontâneo de estruturas próprias da representação" (PIAGET; INHELDER, 1993, p. 64). A análise do desenho permite compreender o período cognitivo que cada sujeito se encontra na construção das relações espaciais.

Da mesma forma que no desenho, a Cartografia para realizar a representação gráfica dos mapas, tem o desafio de "traduzir" um espaço que é tridimensional em um plano bidimensional, e para tanto faz uso de conversões matemáticas baseadas nas relações topológica, projetivas e euclidianas (ALMEIDA, 2014). Desenhar um mapa não é um puro decalque do espaço físico envolve o pensamento, como por exemplo, a abstração de formas, as noções de distância, perspectiva, vizinhança, ordem, ou seja, pressupõem a construção de das relações espaciais. A Figura 2 ilustra a evolução das noções no espaço gráfico.

Figura 2: As relações espaciais no espaço gráfico

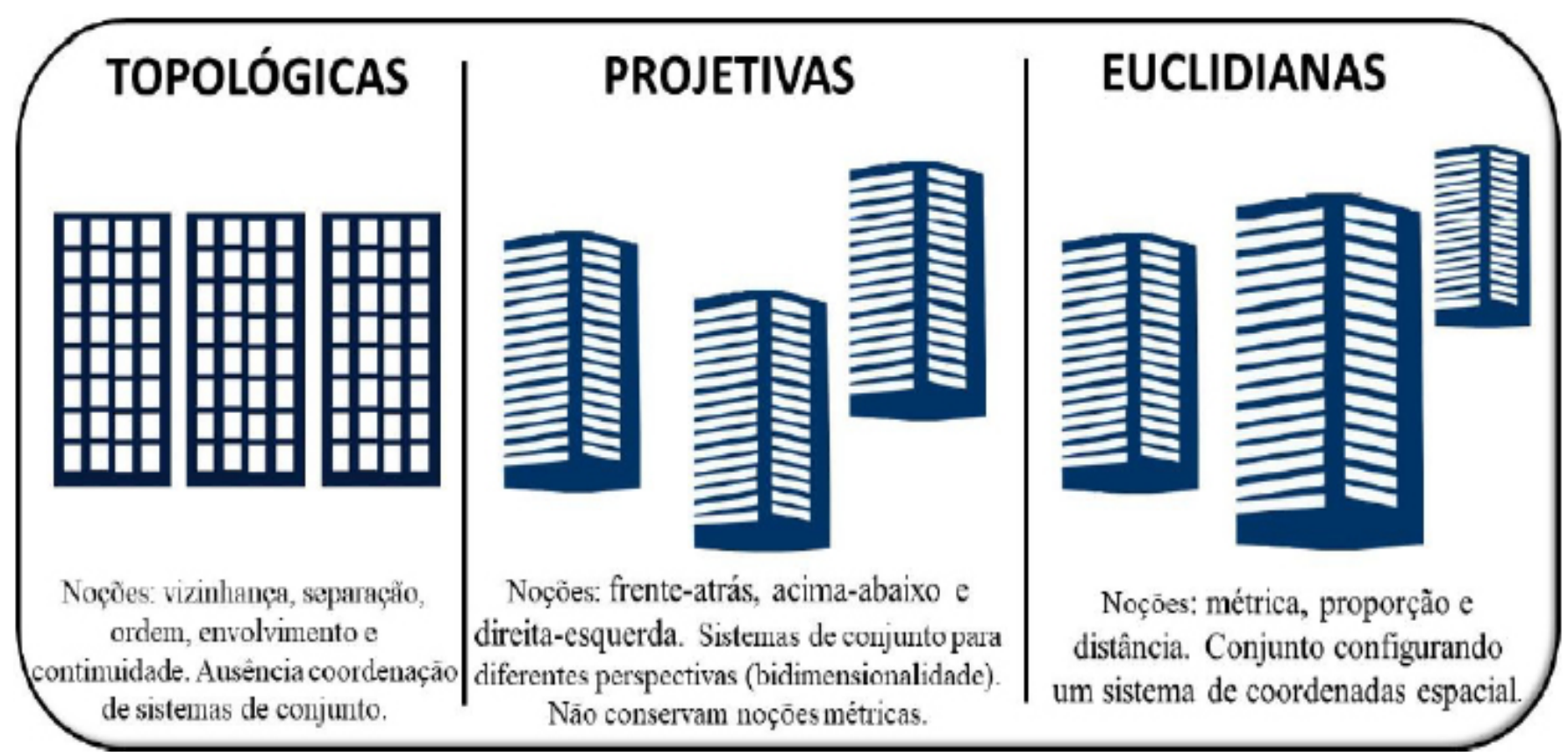

Fonte: GODOI et. al, 2021b, p. 28562. 
Os elementos representados em um mapa têm suas posições estruturadas respeitando as relações topológicas de vizinhança, separação, ordem, envolvimento, continuidade. A diferenciação de perspectiva mostra-se fundamental para alfabetização cartográfica, uma vez que os mapas são figuras planas construídas sob a visão vertical. Já a abstração das formas, as coordenadas geográficas de latitude e longitude e a escala gráfica envolvem as relações euclidianas de proporção, distância e área. Nestas condições o mapa, assim como o desenho espontâneo ou geométrico, revela as estruturas do espaço representativo do sujeito que o desenha.

A construção de noções espaciais pelo sujeito torna-se fundamental para a leitura cartográfica e a compreensão significativa dos mapas. Uma alfabetização cartográfica que abranja além dos elementos formais do mapa, como também os aspectos cognitivos envolvidos em sua representação, cria possibilidades para a construção de conhecimentos cartográficos e geográficos.

\section{A ALFABETIZAÇÃO CARTOGRÁFICA NO ENSINO FUNDAMENTAL I}

Piaget compreende que o conhecimento é um processo que está sempre em construção. A perspectiva piagetiana supõe um sujeito ativo que constrói não apenas o saber, mas os mecanismos e processos com os quais pode conhecer. O conhecimento é resultado de ações que o sujeito emprega sobre os objetos, na busca de alcançar o equilíbrio cognitivo. A esse respeito, Oliveira et al. (2019, p. 182) explica que este equilíbrio se refere "ao avanço do conhecimento menos elaborado para maior grau de complexidade e de abstração [e que nesse processo] os desequilíbrios possuem um papel preponderante na construção do conhecimento". A equilibração envolve ações do sujeito, no sentido de assimilar e acomodar às suas estruturas cognitivas o conhecimento construído na interação com o mundo ao seu redor (PIAGET, 1976). Sobre esse processo, Oliveira e Godoi (2019, p. 140) explicam:

a noção espacial é construção gradativa e depende de conflitos cognitivos advindos do meio social [e físico], mas coordenados internamente, que atuam para desequilibrar o sistema cognitivo e obrigá-lo a descentrar e construir novas relações espaço-representativas. Indicam que o conceito de espaço envolve experiência física, relações lógico-matemáticas e conhecimento convencionado socialmente. 
Sob o enfoque piagetiano, é fundamental que o aluno seja o protagonista na construção dos conhecimentos cartográficos, que ele tome para si o processo de elaborar seus próprios mapas ao invés de apenas analisar mapas já prontos. Conforme Castrogiovanni e Costella (2012, p. 95):

não é possível aprendermos sobre o espaço somente com figuras penduradas em sala de aula e com livros didáticos que apresentam conotações de locais específicos. A análise da realidade social, por intermédio da escola, só é possível quando respeitamos o imaginário, a fantasia, a identidade, a origem e as particularidades, inclusive as subjetividades de quem aprende.

Ao desenhar um mapa ou construir uma maquete o aluno está operando sua representação espacial, esta atividade exige a coordenação das noções de distâncias, proporções, posições, perspectiva etc., ou seja, exige pensar sobre o espaço. Para Castrogiovanni e Costella (2012, p. 96) "nos momentos em que os alunos operam a representação espacial [...] eles (re) constroem o conhecimento". Sendo assim, desenhar um mapa e construir uma maquete possibilita que sujeito elabore as relações espaciais topológicas, projetivas e euclidianas, construindo conhecimentos cartográficos e geográficos. Os autores apontam que a linguagem cartográfica deve ser introduzida por meio de atividades protagonizadas pelo sujeito que conhece. É importante que o próprio aluno construa os contornos e limites do mapa, coordene a visão vertical, identifique as proporções, elabore a legenda, forneça um título do mapa etc. A alfabetização cartográfica supõe um estudo metodológico do mapa para que assim seja possível tanto a construção como a leitura de outros mapas.

Deste modo construir maquetes e mapas pode constituir uma prática pedagógica ativa no contexto escolar. Mas para isso não basta a prática em si, mas a metodologia que a envolve. Sob o enfoque piagetiano, a metodologia ativa para as práticas com maquetes e mapas devem possibilitar a interação entre os pares (aluno-aluno e aluno-professor), a atividade reflexiva sobre o objeto de conhecimento e o processo de equilibração.

Para Castrogiovanni e Costella (2012, p. 74) “a maqueta é um 'modelo' tridimensional do espaço. Ela funciona como um 'laboratório' geográfico [...] No decorrer do trabalho, ocorre a ação do sujeito sobre o objeto e desse sobre o primeiro, ou seja, é um processo interacionista". Conforme os autores as oficinas de maquetes 
podem ser realizadas com alunos desde o $2^{\circ}$ ano do E. F. I e adquirindo maior complexidade com o desenvolvimento do estudante. Os autores sugerem para o $2^{\circ}$ ano a maquete da sala de aula, no $3^{\circ}$ ano o espaço pode ser de uma rua ou bairro (real ou imaginado), no $4^{\circ}$ ano os espaços de diferentes cidades (grandes, pequenas, litorâneas etc.) e para $05^{\circ}$ ano a representação de áreas maiores tendo por base alguns temas como a produção agrícola do Rio Grande do Sul ou a Bacia do Prata.

A construção de maquetes é um dos primeiros passos para o trabalho mais sistemático das representações geográficas, a alfabetização cartográfica torna-se mais significativa com as atividades desenvolvidas com maquetes (CASTROGIOVANNI; COSTELLA, 2012). Os alunos manuseiam, reconhecem, exploram os objetos, abstraem suas formas, proporções, relacionam diferentes perspectivas, ou seja, estão elaborando as noções do espaço representativo.

A etapa seguinte é mapear o espaço da maquete. Neste momento serão acionados e construídos os conhecimentos cartográficos. Para coordenar todos os elementos da maquete em um plano é necessário fazer a abstração da visão vertical. Está é uma atividade ainda muito difícil para os alunos do $2^{\circ}$ ano, pois ainda predominam suas relações do espaço topológico, por isso é interessante começar as maquetes com formas geométricas mais simples como quadrados e retângulos. (CASTROGIOVANNI; COSTELLA, 2012). A maquete facilita a abstração da visão vertical, pois o aluno pode agir diretamente sobre o material construído, posicionando seu olhar por cima da maquete e desta forma orientar a produção do seu mapa. Os alunos mais novos ainda estão sob o primado da inteligência prática, o exercício de mapear a maquete estimula a passagem para o período das operações concretas (mentais).

Os estudos de Castrogiovanni e Costella (2012) mostram que os mapas da maquete produzidos nos primeiros anos do E. F. I apresentam uma perspectiva e métrica pouco coordenada. A redução de escala não é proporcional e a perspectiva é confusa, misturando a visão horizontal, obliqua e vertical. Esta constatação vai ao encontro do pressuposto de Piaget e Inhelder (1993), sobre o caráter tardio das construções do espaço projetivo e euclidiano.

A noção de perspectiva começa a ser diferenciada por alunos um pouco mais 
velhos, conforme observou Castrogiovanni e Costella (2012, p. 104) "no final do $5^{\circ}$ ano, os desenhos são mais organizados e possuem uma sequência lógica de elementos. Percebemos uma facilidade maior de representar o espaço organizado". Os alunos do $5^{\circ}$ ano, com idade entre 9 e 10 anos, já conseguem reconhecer pontos de vista distintos, seus mapas já apresentam construções do espaço projetivo. $E$ por se constituir solidariamente ao espaço euclidiano, este também pouco a pouco alcança novos patamares.

A passagem do espaço topológico para o projetivo é fundamental na alfabetização cartográfica. A visão vertical e a obliqua deve ser trabalhada pelo professor em sala de aula. A construção da maquete é acompanhada pela etapa em que os alunos realizam seu mapeamento. O professor pode orientar seus alunos a desenharem seu mapa a partir de diferentes direções: norte, sul, leste oeste e de cima. Em seguida os mapas são comparados e o aluno deve pensar sobre as seguintes questões: "Qual ponto de vista foi mais fácil? Qual visão é mais apropriada para mapearmos a maquete para que alguém consiga ver a organização da nossa sala de aula?". Com alunos mais novos o desafio é maior, uma estratégia para auxiliar a construção da visão vertical é construir a maquete sobre uma folha de papel. No exemplo da maquete da sala de aula ela pode ser montada sobre uma folha de papel pardo, apoiando nesta as caixinhas de fósforo que representam as mesas e carteiras. Ao terminar a montagem os alunos com um lápis contornam todos os elementos da maquete. Quando removerem a folha de apoio terão o mapa construído sob a visão vertical. Com este exercício o aluno está construindo a noção do conjunto espacial organizado sob uma perspectiva vertical, construindo progressivamente as relações do espaço projetivo à medida que se distancia das relações puramente topológicas, caminhando para um pensamento operatório.

Acompreensão dalegendanos mapaséoutro ponto fundamental na alfabetização cartográfica, uma vez que é por meio dela que se realiza a leitura e interpretação dos mapas. O professor deve explicar o conceito de legenda, trazer exemplos, como também é fundamental que o aluno execute essa prática em seus mapas. A princípio as legendas também devem apresentar grau de complexidade menor, uma vez que os alunos do E. F. I possuem dificuldades em abstrair, por exemplo, que um círculo 
pode representar uma árvore ou uma casa (CASTROGIOVANNI; COSTELLA, 2012). Inicialmente a legenda pode ser representada por símbolos reais, ou seja, o desenho dos próprios elementos: as casas, árvores etc. Após a compreensão da relação entre os signos e significados que constituem a legenda, as representações simbólicas podem ser substituídas até chegar a abstrações mais complexas. Através dessa prática o aluno "está operando o raciocínio para se chegar a uma certa abstração, encaminhando-a para o estágio de operações formais" (CASTROGIOVANNI; COSTELLA, 2012, p. 40). A legenda do mapa da sala de aula pode ser construída a partir de algum tema, por exemplo, o bairro que cada um mora, ou também pode ser escolhido entre os próprios sujeitos.

Os ensinamentos e reflexões que podemos tirar através do trabalho com maquete e mapa em sala de aula evidenciam a importância da atividade ser realizada pelo próprio aluno. O trabalho prático com os objetos e a abstração do espaço construído para o espaço cartográfico aciona nos sujeitos os conhecimentos espaciais e cartográficos envolvidos nessas formas de representação. O conhecimento psicogenético das noções espaciais por parte do professor contribui para o processo da alfabetização cartográfica. Com isso o professor pode operar junto ao estudante, provocando situações que possibilitem o desenvolvimento cognitivo tanto para a produção como para a leitura significativa dos mapas.

\section{CONCLUSÃO}

O texto apresentado objetivou relacionar a teoria piagetiana da representação do espaço com a compreensão significativa dos mapas nos anos iniciais do $E$. F. I. Procurou-se demonstrar a relevância que a alfabetização cartográfica ativa possui para a compreensão significativa dos mapas. Para tanto é importante que os professores dos anos iniciais abordem o mapa do ponto de vista metodológico e cognitivo. A alfabetização cartográfica pressupõe o ensino "do mapa", ou seja, da linguagem específica das representações cartográficas e que inclui também as noções espaciais do espaço representativo do sujeito.

O estudo psicogenético do espaço permite compreender que a construção das noções espaciais é elaborada progressivamente, a partir de ações e movimentos 
cognitivos que o sujeito exerce sobre o objeto. O espaço representativo é constituído primeiramente pelas relações topológicas, consideradas de menor complexidade, e apoiadas sobre o espaço topológico são construídas as relações projetivas e euclidianas. A Cartografia, por sua vez, faz uso de conversões matemáticas baseadas nas mesmas relações topológicas, projetivas e euclidianas, para cumprir o desafio de "traduzir" o espaço que é tridimensional em um a figura plana bidimensional.

Desta forma, consideramos que a coordenação das relações do espaço representativo é fundamental tanto para a leitura dos mapas, como também para sua construção. Sendo assim, mostra-se relevante que a alfabetização cartográfica nos anos iniciais seja conduzida por situações práticas, nas quais o aluno desempenhe o papel de mapeador. $O$ trabalho prático com oficinas de maquetes mostra-se relevante nesse processo, desde que apoiado por uma metodologia ativa, a qual possibilite processos construtivos que enfatizem a interação, a reflexão e a equilibração. Os alunos mais novos ainda estão sob o primado da inteligência simbólica (perceptiva), o exercício de construir e posteriormente mapear a maquete estimula a passagem para o período operatório concreto e operatório formal.

O professor que conhece os processos e as relações envolvidas na representação do espaço na criança pode transformar a cartografia escolar, e possibilitar uma alfabetização cartográfica que contribua tanto para a leitura significativa dos mapas, como também na elaboração e refinamento dos aspectos cognitivos envolvidos na representação do espaço. Sendo assim, torna-se relevante que os cursos superiores de pedagogia contenham em sua grade curricular disciplinas que reflitam sobre estas discussões epistemológicas, como também busquem uma interdisciplinaridade entre os conhecimentos pedagógicos e geográficos.

\section{REFERÊNCIAS}

ALMEIDA, Rosângela Doin. Uma proposta metodológica para a compreensão de mapas geográficos. In: ALMEIDA, R. D. (org.). Cartografia escolar. São Paulo: Contexto, 2014.

BRASIL. Base Nacional Comum Curricular (BNCC). Brasília: Ministério da Educação, 2017. 600p. Disponível em:<http://basenacionalcomum.mec.gov.br/images/ BNCC_El_EF_110518_versaofinal_s ite.pdf>. Acesso em: 05 mar. 2021. 
CASTROGIOVANNI, Antônio Carlos; COSTELLA, Roselane Zordan Brincar e cartografar com diferentes mundos geográficos: a alfabetização espacial. $2^{a}$ edição. Porto Alegre: EDIPUCRS, 2012.

GODOI, Guilherme Aparecido et. al. A teoria piagetiana da representação do espaço e a cartografia escolar: o que as pesquisas informam? Brazilian Journal of Development, Curitiba, v. 7, n. 3, p. 24997-25015, mar. 2021a.

GODOI, Guilherme Aparecido et. al. As noções de espaço e tempo e sua relação com a construção de conhecimentos geográficos. Brazilian Journal of Development, Curitiba, v. 7, n. 3, p. 28556-28571, mar. 2021b.

OLIVEIRA, Francismara Neves et. al. A. O que pensam alunos do ensino fundamental de escolas públicas de Londrina acerca da pobreza? Ciência \& Cognição, Rio de Janeiro, v. 24, n. 2, p. 180- 193, 2019.

OLIVEIRA, Francismara Neves; GODOI, Guilherme Aparecido; Noções de Espaço e Lugar na perspectiva de alunos o $6^{\circ}$ Ano do Ensino Fundamental II: relações de interdependência entre conhecimento social e cognitivo. Ensino Em Re-Vista, Uberlândia, v.25, n. 1, p. 134-158, jan./abr. 2018.

OLIVEIRA, Lívia. Estudo metodológico e cognitivo do mapa. In: ALMEIDA, R. D. (org.). Cartografia escolar. São Paulo: Contexto, 2014.

PAGANELLI, Tomoko lyda. Para construção do espaço geográfico na criança. In: ALMEIDA, R. D. (org.). Cartografia escolar. São Paulo: Contexto, 2014.

PIAGET, Jean. A equilibração das estruturas cognitivas. Rio de Janeiro: Zahar Editores, 1976.

PIAGET, Jean.; INHELDER, Bärbel. A representação do espaço na criança. Porto Alegre: Artes Médicas, 1993.

VIANA, Odaléa Aparecida. Avaliação dos desenhos de planificação de figuras geométricas no ensino básico. Est. Aval. Educ., São Paulo, v. 26, n. 63, p. 838-871, set./ dez. 2015.

WADSWORTH, Barry J. Inteligência e afetividade da criança na teoria de Piaget. 5. ed. São Paulo: Pioneira, 1997. 


\title{
ESCALAS CARTOGRÁFICAS MEDIANDO A REPRESENTAÇO DAS RELAÇÕES ESPACIAIS NO ENSINO DE GEOGRAFIA
}

\author{
ÉDERSON COSTA BRIGUENTI \\ MAURÍCIO COMPIANI
}

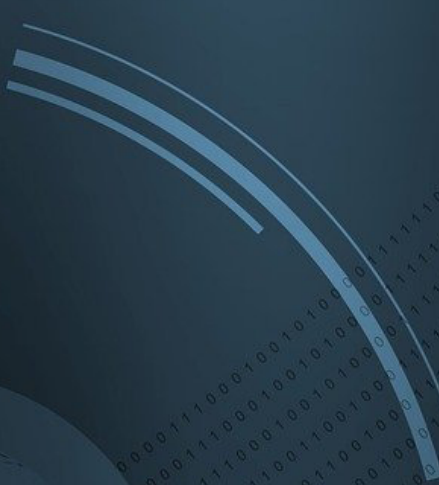

1 Este artigo é resultado de parte da tese de doutorado de Briguenti (2014), que pesquisou a mediação cartográfica no ensino de saberes geográficos escolares.

2 Prof. de Geografia do Ensino Básico da Rede Estadual de São Paulo. Possui licenciatura e bacharelado em Geografia pela Unesp, mestrado em Geografia e doutorado em Ensino de Geociências pela Unicamp. E-mail: edercb@gmail.com

3 Prof. Dr. da Faculdade de Educação da Unicamp. Possui graduação em Geologia pela Universidade de São Paulo, mestrado em Educação, doutorado em educação e livre-docente pela Unicamp. E-mail: compiani@unicamp.br 


\section{INTRODUÇÃO E EMBASAMENTOS}

Toda escolha nos remete à "recortes". Escolhas envolvem uma ou mais opções recobertas por critérios e interesses, que seguramente não passam somente por aspectos técnicos, objetivos e exatos. Esta ideia, no âmbito do conhecimento geográfico nos leva à questão (ou problema) da escala e o modo (ou ausência) de seu tratamento no ensino de Geografia.

Abordar a temática "escalas" no ensino de Geografia, remete a um leque de saberes. Dentre tais possibilidades curriculares, a escala cartográfica envolve um viés metodológico que abordamos por meio de uma proposta de ensino, trabalhada nos anos de 2008 e 2009, com alunos do ensino médio da E. E. Ana Rita Godinho, localizada na cidade de Campinas/SP.

Como a Cartografia pode ser formadora das expressões, interpretações e conceituações do ambiente? Norteado por tal questão problematizadora, nosso objetivo é demonstrar a questão escalar como parte de estratégia pedagógica essencial no ensino de fenômenos e relações espaciais.

Buscando o conceito de escala cartográfica dada por geógrafos, encontramos que "escala é uma relação de proporção entre o tamanho de uma representação e o real" (CASTROGIOVANNI, 2005, p. 52), portanto "indica a relação entre uma distância no mapa e sua respectiva distância real" (SEEMANN, 2013, p.66). Tais ideias podem ser didaticamente demonstrada aos leitores, entretanto, o problema da questão escalar pode estar ali apenas começando... As noções numéricas embutidas na representação, ao atentar para noções de distâncias "reais" e proporções métricas, mascará uma importante reflexão em torno dos critérios e interesses da escolha da escala. Tais interesses, certamente envolvem a produção e análise das representações, sendo alguns critérios fortemente subjetivos.

Iná Elias de Castro (1995) em seu importante artigo, "O Problema da Escala", aponta que o raciocínio analógico entre escalas cartográfica e geográfica dificultou a problematização do conceito, uma vez que a primeira satisfazia plenamente as necessidades empíricas da segunda. A definição e abordagem da escala de análise mostram-se fundamentais e presentes no pensamento da ciência geográfica, diante 
da espacial e simbiótica relação entre metodologia e conhecimento (olhar/objeto).

Castro (1995) comenta que o problema da escala vai além de uma medida de proporção da representação gráfica do território, possuindo novos contornos para expressar a representação dos diferentes modos de percepção e de concepção do real. A escala portanto, definitivamente não é neutra. Contribuindo com essa concepção, Jörn Seemann afirma que "queiramos ou não, ao escolher uma determinada escala, selecionamos arbitrariamente um recorte da totalidade, deixando de fora os fenômenos que não podem ser apresentados na mesma escala". (2013, p.69).

Entretanto, no âmbito da prática escolar, pouco se avança em tais discussões, aqui defendidas como fundamentais. De modo geral, nota-se dois problemas principais no tratamento da escala no ensino do conhecimento geográfico. Ambos, não são conceituais, mas sim metodológicos. Um deles refere-se ao status de "convenção cartográfica", sendo um item a mais dentre os demais que devem compor um mapa. Neste tratamento, a escala é "reduzida" ao aspecto dimensional, em recortes cartográficos que indica a proporção entre o espaço e a representação em cálculos métricos. Exemplificando o problema de tal abordagem, pontua-se a preocupação pedagógica na diferenciação de escala gráfica e escala numérica, voltando o foco da aprendizagem para aspectos mais técnicos e conceituais da presença da escala nos mapas. O outro, refere-se ao tratamento do fenômenos geográficos dos conteúdos curriculares, tanto aspectos cotidianos, quanto fatos ocorridos no mundo, sem que se faça relações analíticas com as escalas geográficas (local, regional e global), essências na compreensão dos fenômenos e processos espaciais. Tais relações escalares são intrínsecas à compreensão do fenômeno estudado, análises que poderão ser facilitadas por meio de sua representação, e as devidas reflexões que a escala cartográfica irá proporcionar.

Fenômenos geográficos, abordados por meio de representações cartográficas, pressupõem relações espaciais que explicam a sua existência, a sua localização e suas condições. A definição da escala geográfica e escala cartográfica, na verdade, representa um recorte espacial, que por sua vez, constitui-se numa escala de análise de tais aspectos e relações. 
A preocupação no ensinamento da proporcionalidade métrica de escalas, como $1: 1000$ (onde $1 \mathrm{~cm}$ no mapa equivale a $1000 \mathrm{~cm}$ no real), acaba se restringindo a compreensão da conversão matemática. Desse modo, segundo Seemann (2013) deixa-se de refletir que por trás de tais raciocínios, escondem-se uma relação entre representação da realidade e realidade representada.

A proposta de ensino aqui apresentada, busca o tratamento conceitual de escalas espaciais (geográficas e cartográficas), buscando construir práticas escolares voltadas a abordar relações espaciais cotidianas e "cartografadas", existentes/produtoras nos/de espaços sociais, porém, demasiadamente ocultas em nossos olhares e representações. Desse modo, necessitam de diagnósticos, percepções e reflexões mais abrangentes e integradas.

Castro (1995) ressalta que recortes integram analiticamente níveis de conceituação, níveis de intervenção e níveis de realidade. Entretanto, não devem ser reduzidos e solucionar-se nas diferentes representações cartográficas, confundindo-se a escala fração com a escala extensão. O autora acrescenta que o significado das escalas, portanto, não é meramente matemático.

Contribuindo com tais reflexões, Corrêa (2007) defende que a escala é uma construção social com três acepções: a de dimensão; a cartográfica e a conceitual. Esta última nos interessa, pois está associada à ideia de que objetos são conceitualizados em uma determinada escala, na qual, processos e relações se tornam específicos, tendo sua própria escala de representação cartográfica.

A análise de situações de riscos, por exemplo, por contemplar noções escalares, tanto em termos conceituais, quanto na aplicabilidade, pode ser enriquecida por abordagens sistêmicas que demonstrem relações de "ação-reação", "causa-efeito", que por sua vez, são relações espaciais que não são estabelecidas e compreendidas apenas no local.

Assumir o pressuposto de que a diferenciação sócio-espacial manifesta-se de modo distinto em escalas conceituais, discutido por Corrêa (2007), demanda uma abordagem pedagógica mais profunda, envolvendo possibilidades da Cartografia, assim como, a importância da escala no ensino geográfico escolar, buscando não 
alimentar a ingênua visão, de uma mera convenção (ou conversão) de medidas métricas entre o real e a representação, traduzindo-se em "frias" relações entre sujeito-objeto, por meio do mapa.

Nesse contexto, o conceito de escalas, foi trabalhado com o objetivo pedagógico de demonstrar a relação direta da escala espacial com as distintas finalidades e possibilidades analíticas de suas representações. Ou seja, demonstrar e se aprofundar nas correlações das escalas espaciais com suas aplicações, por meio da concepção de "escala de análise", em que se estabelece uma hierarquia analítica que define uma "escala de relações" espaciais. Relações pessoais, socioculturais, ambientais, passíveis de serem estudadas e espacializadas em detrimento de vivências cotidianas associadas a sua escalas e representações gráficas.

Constata-se que no ensino básico, inter-relações pouco são representadas pelos mapas escolares tradicionais e, não são claramente concebidas pelos alunos. Entretanto, tais relações, além de serem "chaves epistemológicas" para a disciplina de Geografia, são passíveis de serem abordadas, tanto no produto cartográfico, quanto no seu processo de mapeamento. Didáticas com este fim, contribuem na elaboração de um conhecimento escolar por meio de mapas escolares em distintas escalas, que remetem às seletivas interpretações expressas e socializadas entre os alunos. Afinal, assim como afirma Doren Massey (2008, p. 22)," o modo como imaginamos o espaço tem seus efeitos".

Com desenvolvimento de conteúdos geográficos disciplinares, trabalhados juntamente aos estudos de escalas de análise, espera-se favorecer a caracterização de interações espaciais, onde, as relações estão atreladas às condições constatadas, aos diversos atores, seus interesses e, até mesmo, às intervenções mais necessárias e adequadas.

Ao abordarmos temáticas como: processos erosivos, áreas de risco, inundações ou fluxos migratórios, por exemplo, é fundamental a reflexão sobre diferentes escalas espaciais. Em função destas, a espacialização de tais fenômenos, estabelece níveis de detalhamento e generalização, condicionando análises das relações com o ambiente. Os riscos ambientais, por exemplo, apresentam uma diversidade 
de conexões e interações que permeiam e se manifestam nas escalas geográficas global, regional e local.

Neste sentido, o local, por possuir forte vínculo da percepção nas relações pessoais do cotidiano, permite estabelecer comparações com outras escalas de análise. $\mathrm{Na}$ escala das relações cotidianas, a cartografia-escolar-que-se-quer consiste num elo que integra a representação do local/ambiente com relações cotidianas. Por meio desta "cartografia cotidiana", revelam-se políticas e "escalas de atuação" das ações individuais e coletivas, no contexto sócio-histórico-espacial local. A espacialização e discussão de tais ações podem despertar consciências e atitudes, em escalas mais participativas.

Diante tais reflexões sobre um conjunto de ideias e práticas atreladas à cartografia escolar, trabalhamos com diferentes escalas métricas e, com distintas escalas e visões de mundo e, com as distintas formas de expressá-las cartograficamente, mediante interesses e contextos específicos.

\section{DESENVOLVIMENTO}

Tratando sobre as particularidades conceituais e suas aplicações, buscou-se demonstrar para os alunos que a definição de escalas se relacionava com um recorte espacial, constituindo-se assim, uma escala de análise.

No contexto desta ideia, realizamos discussões coletivas a partir da exposição de diversos mapas em distintas escalas. Esta discussão foi mediada pelo professor a partir de um quadro síntese exposto na lousa (figura 01), com as peculiaridades de escalas pequenas, médias e grandes, a fim de se deixar mais claro, diferenciar conceitos entre escala geográfica, escala cartográfica e escalas pequenas e escalas grandes, assim como as aplicações, peculiaridades, vantagens e desvantagens de cada uma delas.

Procurou-se deixar claro que a definição da escala dos mapas, define também os níveis de detalhamento e generalização dos elementos, que por sua vez, define e condiciona análises da área mapeada e relações com o entorno. 
Figura 1 - Quadro síntese: particularidades das escalas de análise

\begin{tabular}{|c|c|c|c|c|c|}
\hline $\begin{array}{c}\text { Escala } \\
\text { Cartográfica }\end{array}$ & $\begin{array}{c}\text { Escala } \\
\text { Geográfica }\end{array}$ & Detalhes & Generalização & $\begin{array}{c}\text { Área } \\
\text { Mapeada }\end{array}$ & $\begin{array}{c}\text { Tamanho dos } \\
\text { Elementos } \\
\text { Mapeados }\end{array}$ \\
\hline $1: 10.000$ & Local & + & - & - & + \\
\hline $1: 500.000$ & Regional & & & & \\
\hline $1: 50.000 .000$ & Global & - & + & + & - \\
\hline
\end{tabular}

Fonte: Briguenti (2014).

Posteriormente, distribui-se aos alunos em grupo, diversos mapas com distintas escalas, para que indicassem as escalas espaciais dos mesmos, juntamente com a análise a respeito de detalhamento, generalização, área mapeada e representatividade dos elementos espaciais. Nesta análise, orientou-se para comparação entre os mapas, buscando correlações entre as diferentes escalas, a fim de refletirmos sobre as peculiaridades e finalidades que cada uma delas apresentam.

A atividade teve como principal propósito demonstrar que, por meio de uma convenção cartográfica, é possível se definir "olhares" e análises espaciais. Escalas, determinam reflexões sobre relações sócio pessoais e práticas espaciais possíveis de serem visualizadas e representadas, demonstrando que a própria escolha da escala não é neutra, pois definem-se critérios relacionados aos aspectos que interessam mostrar ou esconder.

Dando continuidade à proposta pedagógica, propôs-se a realização de um mapeamento da escola e seu entorno. Para enriquecer a atividade de, realizamos um trabalho campo, percorrendo de ônibus, locais entorno da escola, com paradas em locais que poderíamos discutir as particularidades e relações espaciais percebidas recordadas ao longo do trajeto.

Posteriormente em sala, individualmente ou em grupo, os alunos escolheram um mapa-base, tendo como opções escalas entre 1:500 a 1:10000. O mapa-base, foi elaborado previamente pelo professor, nele contia o arruamento (sem o nome das ruas), cursos d’água e cotas altimétricas. todos tinham como referência central a localização da escola Ana Rita. 


\section{RESULTADOS E DISCUSSÃO}

Fruto desta proposta de ensino, iremos analisar 3 desses mapas, com o intuito de colocar em diálogo, análises e observações. No mapa intitulado "Relação: Eu e o Ambiente" (figura 2), a aluna demonstra uma interessante forma de assimilar o espaço a partir de uma categorização da sua experiência com local, demarcando categorias por meio de áreas "pouco familiar a mim", "familiar a mim" e "muito familiar a mim". Nota-se que a aluna buscou representar o espaço a partir de referências pessoais, e já no título aponta para uma superação da dicotomia sujeito-objeto.

Nas relações conceituais entre espaço e lugar discutidas por Tuan (2013), o espaço se torna menos abstrato e indiferenciado à medida que o conhecemos melhor e o dotamos de valor, por meio do contato com os sujeitos sociais, caracterizando gradualmente o espaço-lugar. Nesse sentido, ver e pensar são, portanto, processos intimamente ligados importantíssimos no desenvolvimento cognitivo do indivíduo. A experiência da aluna com o local mapeado, permitiu abranger diferentes maneiras pelas quais uma pessoa percebe, concebe e constrói a realidade social.

Evidente que tais olhares podem estar relacionadas aos estímulos dados aos nossos sentidos em distintas situações presenciais e "experienciadas", podendo estas serem mais diretas, ou, em processos mentais de simbolização, ou seja, mais indiretos. Ambas, revelam e constroem valores afetivos que remetem nossas lembranças aos aspectos vivenciados e influenciam nossas relações com os distintos locais/ambientes.

Neste sentido, mapear pontos de ônibus se mostra significativo. Mesmo que alguns destes não tenha demarcações espaciais visíveis, a sua espacialização se mostra representativo para a autora. Esta representatividade possui relações com a espacialidade afetiva que nos é apresentada, onde todos os pontos mapeados estão próximos a áreas muito familiar, de uma aluna, que se sabe, utilizava transporte coletivo no trajeto escolar.

Neste sentido, podemos aqui retomar a ideia de Tuan (2013), frente ao dinamismo do espaço geográfico, expondo que o lugar é uma pausa no movimento. Esta pausa proporciona processos psicológicos, faz parte e é determinante das relações socioespaciais do indivíduo. Relações que se diferem daquelas que percorre de 
modo a estabelecer poucos laços afetivos, em oposição ao momento de pausa proporcionado pela espera do ônibus. A pausa aqui, aponta espaços que se tornaram centro de reconhecido valor. Acontecimentos, olhares, amigos, brincadeiras, um beijo, enfim, tudo que a faça até "perder" o ônibus, colaboram em criar e transformar a relações espaciais em um sentimento profundo e representativo pelo lugar.

Juntamente às classificações de categorias afetivas, a aluna enfatiza a existência de "solo antropizado", em referência à área adotada ao lado da escola, demonstrando uma assimilação de discussões escolares, que abordaram tipologias de solo urbano, por apresentarem alto nível de alterações e resíduos, provocados pelo processo de ocupação humana.

Além disso, utiliza-se de formas lineares com distintas espessuras para indicar as ruas com mão dupla. Representou os fluxos de pessoas e dos meios de transporte (abreviados como "M.T") em todas as vias do mapa. Deste modo, constata-se que buscou estabelecer critérios de categorização da própria experiência e percepção com o espaço representado.

Figura 2. Mapeamento do entorno da escola na escala 1:2000.
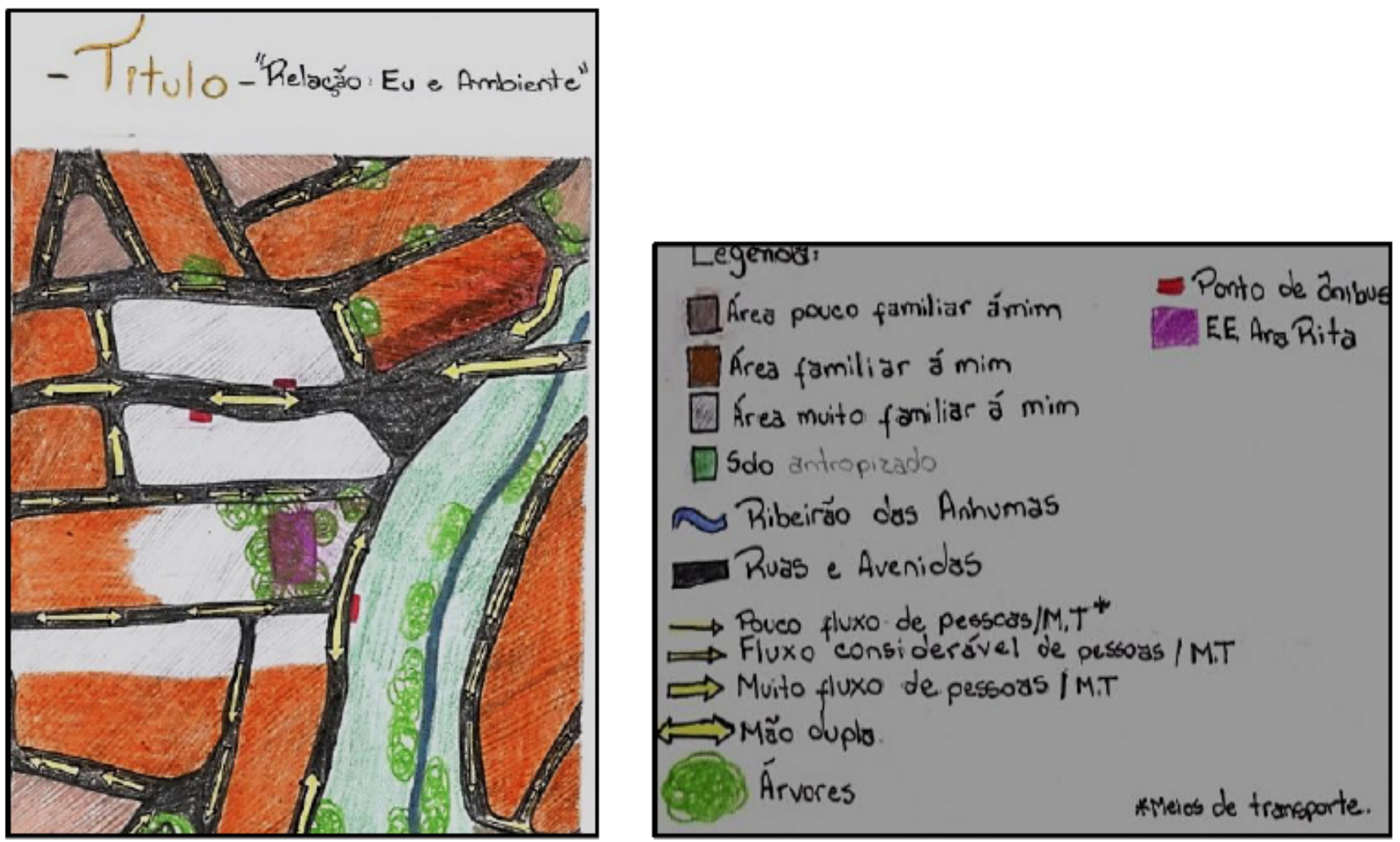

Fonte: Briguenti (2014). 
Em um outro mapa (figura 3), os alunos utilizam-se de círculos para expressar lembranças que a escala métrica proporcionou. As formas circulares favoreceram estabelecer relações de tal simbologia com a ideia de que o lugar não se constitui em demarcações espaciais concretas e homogêneas. Aspectos emotivos envolvidos no "espaço praticado", nortearam a definição do signo, espacializados por recordações, por meio de aspectos psicológicos, e que por isso, não se apresentam em demarcações rígidas e os tornam afetivamente e espacialmente intercomunicáveis com os outros lugares, inclusive, com alguns círculos se sobrepondo, proporcionando comunicações singulares, pouco voltadas à precisão.

As localidades de tais lembranças foram numeradas e na legenda nomeadas. Nota-se uma variedade de localidades, como, residência dos alunos, casa de familiares, o ribeirão, o distrito policial, escolas, supermercado, campo de futebol, praças e parques. As cores definidas de modo a qualificar as recordações em: lembranças ótimas, boas e ruins.

A escola Ana Rita e a casa da vó de Márcio foram as únicas classificadas como lembranças ótimas. Entretanto, o círculo da escola, a exemplos de outros, como o ribeirão Anhumas e o supermercado Dalbem são classificados com duas cores. $A$ divisão do círculo demonstra reflexões em torno de critérios na representação da predominância das qualidades das lembranças, não seguindo necessariamente uma lógica binaria. Além disso, a opção por limites sinuosos, entre tais recordações, proporciona um aspecto dinâmico, dialético e de pouca rigidez às significações do símbolo.

Importante destacar que riscos ambientais também foram lembrados, localizados e divididos em "riscos de erosão" e "falta de sinalização". A presença de riscos ambientais no mapa favorece uma reflexão, envolvendo critérios representacionais dos autores. O uso de forma triangular com tamanho reduzido garante uma diferenciação na expressão do próprio pensamento. O fato de os riscos serem representados por meio de um outro símbolo indica que tais aspectos são frutos de percepções dos alunos, ou de recordações de eventos presenciados, mas que não os afetaram diretamente. Algumas ruas ganharam destaque com cores, simbolizando trajetos percorridos pelos autores para chegarem à escola. $O$ restante do arruamento, de- 
nominado "demais ruas", cuidadosamente foi pintado de cinza, resultando em sua visibilidade espacial.

A opção dos alunos na escala cartográfica evidencia uma simbólica relação entre sujeito e objeto, demonstrando que o problema da escala vai além de uma medida de proporção da representação gráfica do território, pois sua escolha também nos apresenta possibilidades de expressão de distintos pensamentos e percepções, por meio do recorte espacial.

Portanto, a escolha da escala não se deu de modo arbitrária, dimensionando a abrangência espacial das lembranças, deixando de fora recordações que não puderam (ou se não desejou) ser apresentadas. Exemplificando esta discussão, de não neutralidade escalar, destacamos que a escolha do grupo permitiu representarem a totalidade de seus trajetos até a escola, além de inúmeras lembranças que possuem com o espaço, que a escolha escala cartográfica garantiu aos alunos recordarem e espacializarem ao leitor. 
Figura 3. Mapeamento do entorno da escola na escala 1:7500
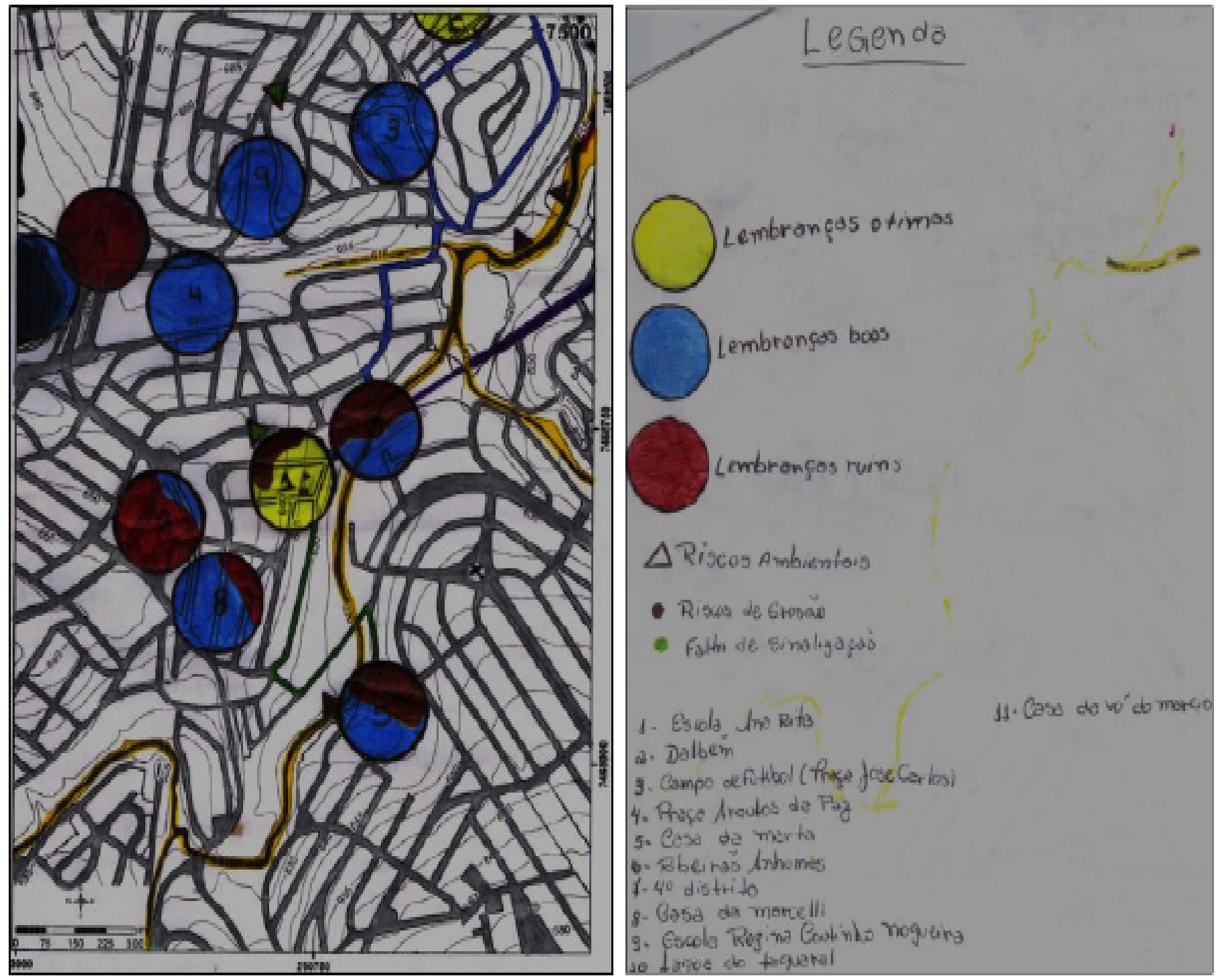

Fonte: Briguenti (2014)

No mapa intitulado: Algo sobre paisagismo (figura 04), a aluna-autora demonstra que incertezas e tentativas de conceituações assumidas nas decisões e reflexões são inerentes ao processo cartográfico. A incerteza aqui favorece relações pedagógicas e conceituais entre conhecimento espontâneo e o conhecimento científico, tratando as percepções pessoais em atividades de ensino que proporcionem concepções e práticas socioculturais. Oficina mecânica; Ponto de ônibus; Loja de Som de carro (símbolo remete à vibrações sonoras); Casa onde se concerta móveis. Pequenos carros na rua ou dentro de casa e Comércio pequeno, envolvem uma discussão conceitual mais ampla de escala, e, agregam valores qualitativos e quantitativos aos elementos espaciais. 
A preocupação no detalhamento histórico espacial em um dos itens da legenda nos revela: um Lugar onde há muita terra e mato, e completa, é um lugar que com chuvas muito fortes há risco de erosão. Estabelece assim, em sua legenda/narrativa relações geográficas de causa-efeito, envolvendo chuvas intensas e impactos ambientais. E finaliza resgatando um evento climático extremo ocorrido na cidade de Campinas, contando nos que até com a chuva de 2002 levou uma ponte que tinha nesse meio. A historicidade aqui evidenciada nos remete à um "olhar pensante" e "consciência visual", demonstrando que a aluna-autora demonstra uma capacidade de produzir imagens ligadas ao contato direto com aquilo que é visto. O ensino de Geografia aqui exerceu papel importante neste processo de desenvolvimento, por envolver a habilidade de desvelar/revelar memórias e percepções espaciais a partir da observação mediada pela cartografia.

Essa pontinha é um lugar de risco, pois como ela fica embaixo do pontilhão, uma garota já foi violentada lá. Tal conhecimento e percepção garantem um caráter denunciador no ato de mapear, revelando aspectos escuros e obscuros do espaço, em expressões que transcendem a ação pedagógica, trazendo à tona memórias coletivas que demandam mobilização da comunidade local para discussões e ações, que certamente irão apontar anseios de mudanças a serem ditas e ouvidas em devidas escalas do poder público.

Nas relações entre sujeito/objeto que o produto cartográfico inexoravelmente reflete, o "eu" do mapa em questão, presencia-se e toma o centro abstrato do recorte espacial, por meio das relações e lembranças, e se revela conceitualmente nas categorias utilizadas na generalização das residências apresentadas como casas da vizinhança.

Nestas intrínsecas relações, representadas por exemplo, pela Casa do meu ex-namorado (quase ex meu bebê) e também foi onde fiquei c/ ele pela $1^{\text {a }}$ vez (sinalizado com o universal signo de afeto), a história sócio-cultural e as memórias pessoais marcantes são significativas para os valores espaciais afetivos, determinantes em nosso comportamento.

No item "Casa do Jaime, tio do meu ex-marido (ex-mesmo). A casa é laranja pelo fato dele trabalhar com laranjas." Demonstra que o mapa em questão utiliza de 
uma espacialidade, para informar e reforçar aspectos pessoais e temporais, como fatos e (ex)relações que a autora deseja deixar bem esclarecidos aos leitores (ou a si mesmo), seguido de uma curiosa necessidade de justificar o uso do signo empregado.

Justificativas inusitadas como, Pintei de rosinha claro os espaços em branco para serem os quintais das casas e o chão da escola. Porque as casa não são gigantes, mas que apresentam processos mentais do indivíduo na autêntica produção da cartografia, que podem ser envolvidos no ensino de Geografia, por meio da reflexão e expressão psicossocial da linguagem.

No item a casa do zagão, o zelador da escola (acho) a dúvida apresentada, tanto à temática ou a localização, assumi a incerteza como parte das condições de estudo e criação, em que, neste processo, demonstra-se autoria e autenticidade, por agregar saberes que não são sistematizados em mapas convencionais. Deste modo, permite que dúvidas e imprecisões alimentem as possibilidades de criação, fundamentais no saber escolar.

$\mathrm{Na}$ "Quadra de vôlei, onde na $7^{a}$ série fui a capitã do time de meninas jogando bola (entre a $5^{a}$ e $6^{a}$ série)", favorece-se uma compreensão do espaço geográfico em suas temporalidades coetâneas, que trazem consigo recordações que proporcionam reações e emoções. O reconhecimento e mapeamento de tais momentos apontam para a internalização do fator histórico como inerentes ao espaço, sendo concebido por olhares que podem proporcionar, conjuntamente, processos de sistematização do conhecimento e noções de identidade e pertencimento. Temos assim a representação de temporalidades que as atitudes e trajetórias carregam, noções essenciais para discussões amplas do espaço-temporal, que os fenômenos e as práticas espaçais se constituem.

Diante desta discussão, o item da legenda Banco da escola, onde eu quase bati na Gislaine, mas a Lary não deixou, porque eu estava grávida - 8a. série, enfatiza importantíssimas recordações e relações escolares, acontecimentos simples que se transformaram em sentimentos profundos pelo lugar, que o processo cartográfico escolar captou. 
Figura 4. Mapeamento do entorno da escola na escala 1:1000
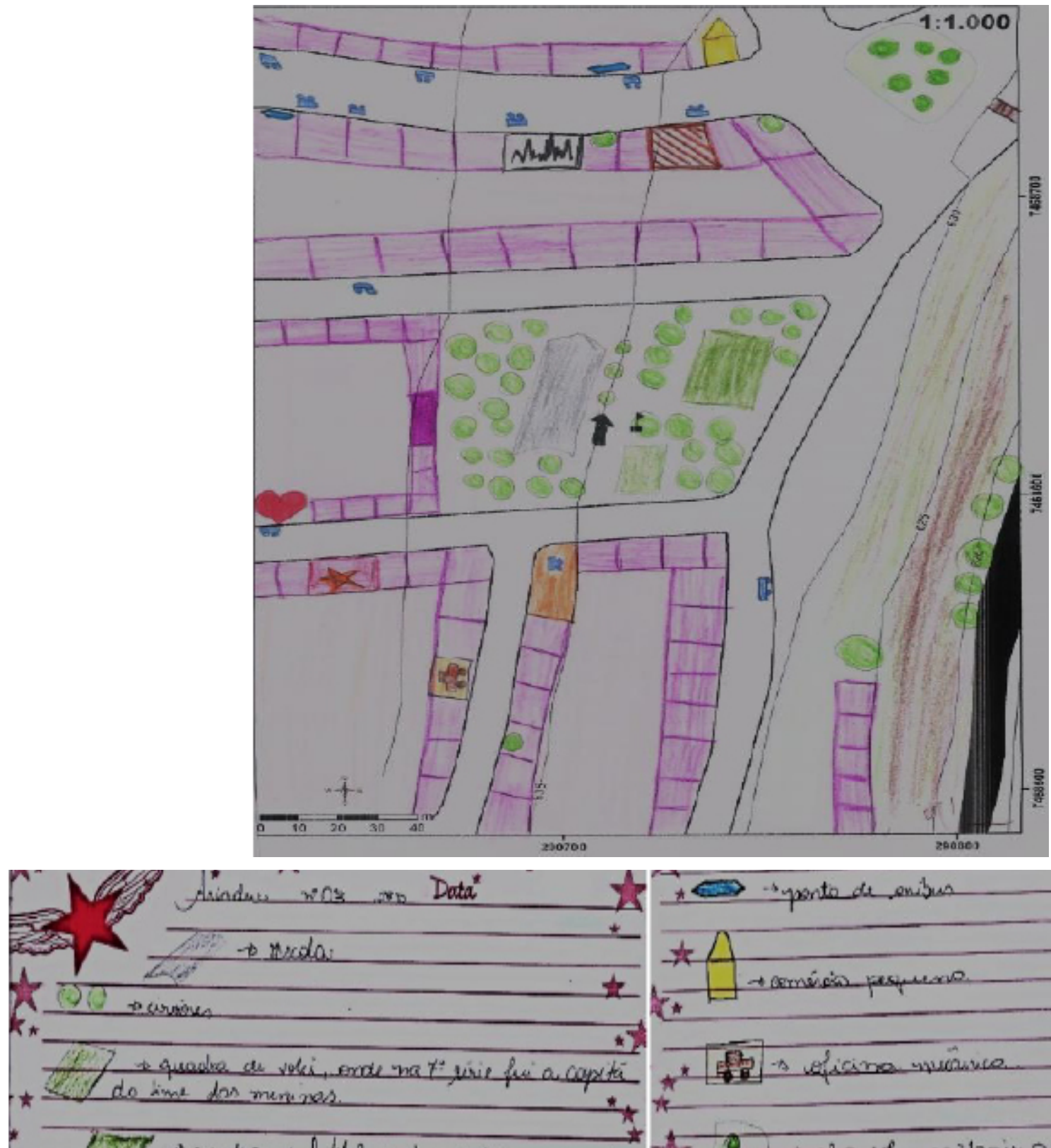

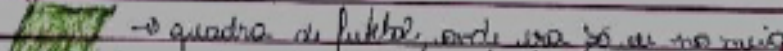

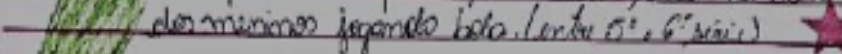

学 $x+$

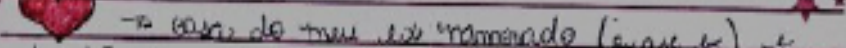

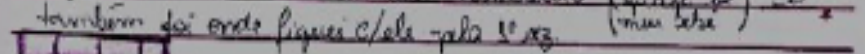

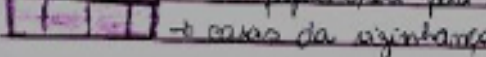

A.

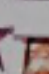

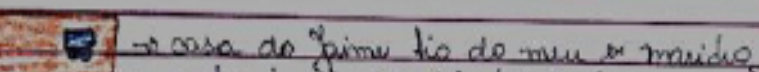

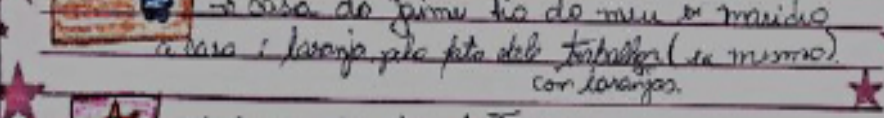
A. $\rightarrow$ ease do tia do tiage

\section{$-1$}

is

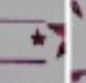

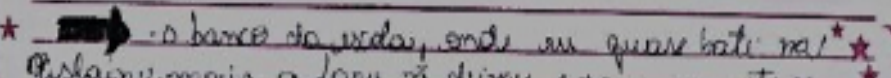

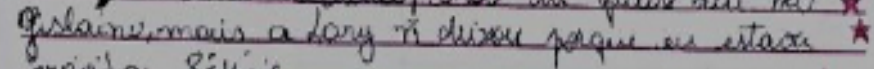
Anivila sifinis

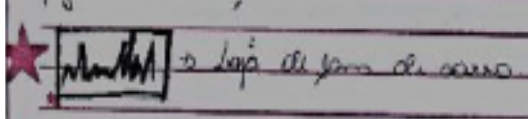

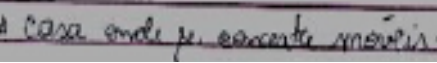

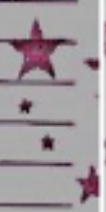

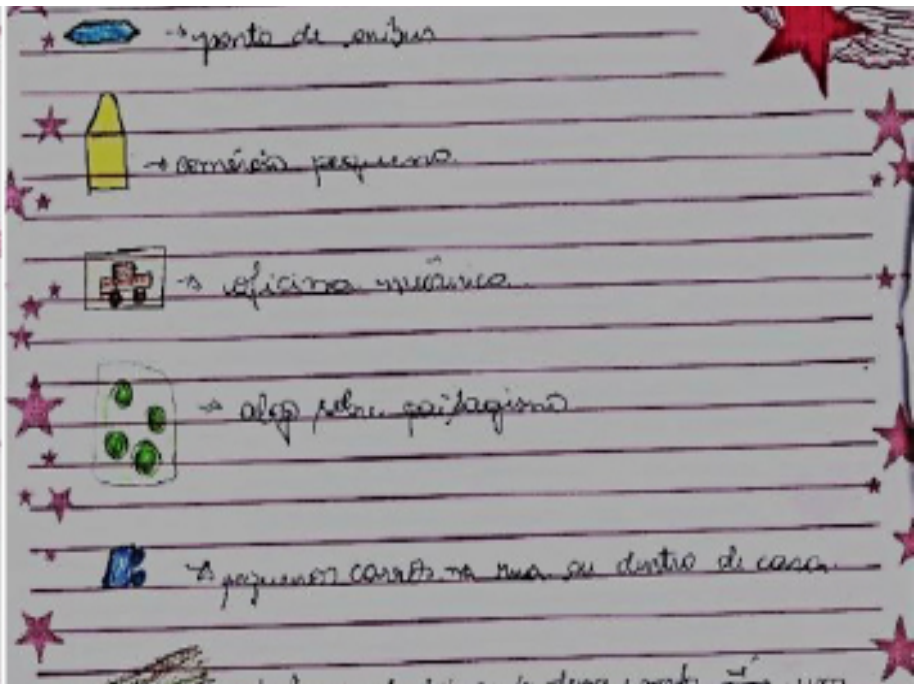

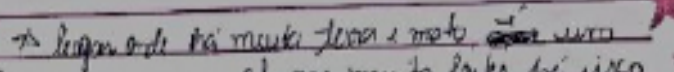
lupar chures muto fores he visco

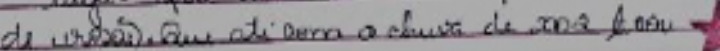
wora ponte Qure kinfore nese mise

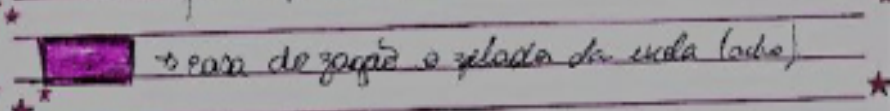

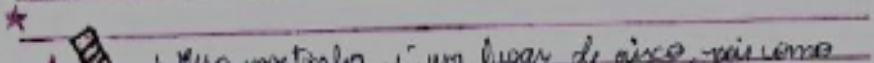

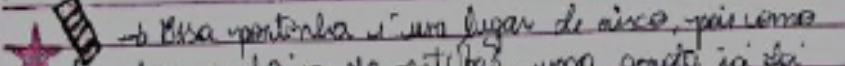
Dila vira embaizo de gent tas, una gavia ja pa stroleriade leir

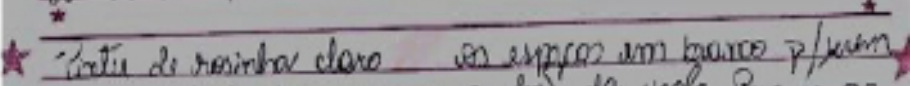

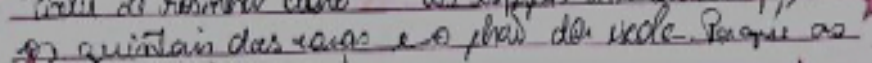

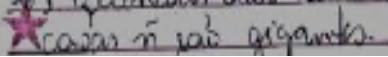
$+\rightarrow$

Fonte: Briguenti (2014) 


\section{CONSIDERAÇÕES E CONCLUSÕES}

A abordagem escalar mediando as atividades escolares contribuiu de modo significativo para processos formativos pedagógicos e sócio-históricos, por envolver uma problemática mais cotidiana e ampla das relações pessoais e dinâmicas espaciais, sobretudo do espaço público, onde, as relações ali presentes, podem se constituir num viés dialético-político, diante da necessidade de mudança.

Mudar valores, atitudes, decisões, meios legais no processo... Mudar. Quando se compreende o lugar onde se vive, o bairro, como resultado de relações dinâmicas, concebe-se o espaço aberto para mudanças. Sabe-se que este, com participação dos indivíduos nos processos de decisão, se transforma.

Mediante as formas de perceber o espaço, ora mais objetiva/consensual (conceitual) ora mais subjetiva/perceptiva, resultou mapeamentos de relações da "escala cotidiana", numa certa "oposição" e analogia às escalas numéricas dos mapas geográficos escolares tradicionais. Desta oposição, buscamos alcançar a escala na qual vivemos a ação, nos detemos e avançamos.

Trabalha-se, em parte, com uma negação da objetividade da representação de elementos "frios" e concretos. A realidade vivida, mediada pela linguagem, deve ser exposta, compartilhada, confrontada, num complexo contexto escolar de múltiplos sentidos, interpretações e vivências. A síntese surge apenas como uma possibilidade de reflexão de noções espaciais e o modo como nos enxergamos e nos relacionamos com o outro e pelo o outro.

Neste contexto, a cartografia escolar se constituiu como importante suporte linguístico e metodológico para um ensino mais dialógico, permitindo em tais abordagens, atravessarmos o espaço da representação para nos presenciar, saindo do plano estático, para dimensões mais dinâmicas das práticas culturais e ambientais, para dimensão do espaço das emoções e tensões. Neste contexto,

"a criação de uma cartografia não responde apenas a critérios objetivos ou técnicos; os aspectos subjetivos, as sensações, as respostas do corpo, também participam dela, trazendo a dimensão da experiência.(...)A cartografia se configura como um pêndulo entre a representação e a busca por intervir no território, procurando gerar mudanças de percepção, mudanças na chave de olhar". (Coletivo Política do Impossível, 2004). 
O ensino de Geografia, colaborou em demonstrar que a Cartografia também é formadora de opinião e, assim se faz, estruturando e demonstrando relações de poder e, como estes se articulam para produzir generalidades e homogeneidades, e por meio desses, padrões, consensos e aceitação.

Diante da multiplicidade de trajetórias e relações coetâneas que o espaço se constitui, cabe ressaltar que o espaço do convívio/ensino escolar igualmente se configura por múltiplas visões de mundo. Suas cartografias, portanto, não necessitam ser uniformes, homogêneas e predominantes, de modo a sobrepor-se à escala dos interesses do que/como aprender.

Ressalto, que para o educador, visões mais tradicionais da cartografia nas práticas de ensino, proporciona invisibilidade das abstrações psico-espaciais e sócio-históricas dos seus alunos, distanciando-o assim, de práticas de mediação entre o saber sistematizado e o saber espontâneo no processo de aprendizagens educacionais. Certamente as abordagens no tratamento da escala no ensino de Geografia podem colaborar em fortalecer ou desconstruir este quadro.

As interações no contexto escolar, diante da bagagem que alunos carregam, são prósperas para introdução de um desafio à prática docente: pensar uma cartografia que considere em seu conceito e processo de mapeamentos, aspectos imensuráveis, que, se contemplados no estudo do local e na mediação pedagógica, fazem da dimensão escalar espacial, repleta de significados pessoais e, consequentemente, uma dimensão de luta, de recombinações e ainda mais dinâmico, se assim o desejarmos. A afirmação de Tuan (2013) de que um indivíduo pode aceitar a restrição e a liberdade, a limitação do lugar e a amplidão do espaço, permite-nos refletir que esta decisão certamente irá passar pela questão escalar.

\section{REFERÊNCIAS}

BRIGUENTI, E. C. Cartografia e Contexto: a linguagem simbólica e as múltiplas relações cotidianas mediando o ensino de Geografia. Tese de Doutorado. Campinas, SP: [s.n.], 2014.

CASTRO, I. E. O Problema da Escala. In: CASTRO, I. E.; GOMES, P. C. C.; CORREAA R. L. (orgs.) Geografia: Conceitos e Temas. Rio de Janeiro: Bertrand Brasil. 1995. 
CASTROGIOVANNI, A. C. Apreensão e compreensão do espaço geográfico. In: CASTROGIOVANNI, A. C (org.) Ensino de geografia: práticas e textualizações no cotidiano. Porto Alegre: Mediação, p.11-81, 2000.

CORREAA, R. L. Diferenciação sócio-espacial, escala e práticas espaciais. Cidades, v. 4 , n.6 , 2007, p.62-72.

COLETIVO POLÍTICA DO IMPOSSÍVEL. Cidade Luz: Uma investigação no centro de São Paulo. Editora PI. 2004.

MASSEY, D. Pelo Espaço: uma nova política da espacialidade. Trad. Rogério Haesbaert, Hilda Pareto Maciel. Rio de Janeiro: Bertrand Brasil, 2009.

SEEMANN, J. Carto-crônicas: uma viagem pelo mundo da cartografia. Fortaleza: Expressão Gráfica e Editora, 2013.

TUAN, Yi-Fu. Espaço e lugar: a perspectiva da experiência. - Londrina: Eduel, 2013. 


\section{ENSINO DE GEOGRAFIA E NOVAS TECNOLOGIAS: MICROSOFT WORD ${ }^{\circ}$ APLICADO À ATIVIDADE DOCENTE}

CAMILA ARAUJO GOMES MEDEIROS RAFAEL REIS BAGELAR ANTON ORIANA ARAUJO

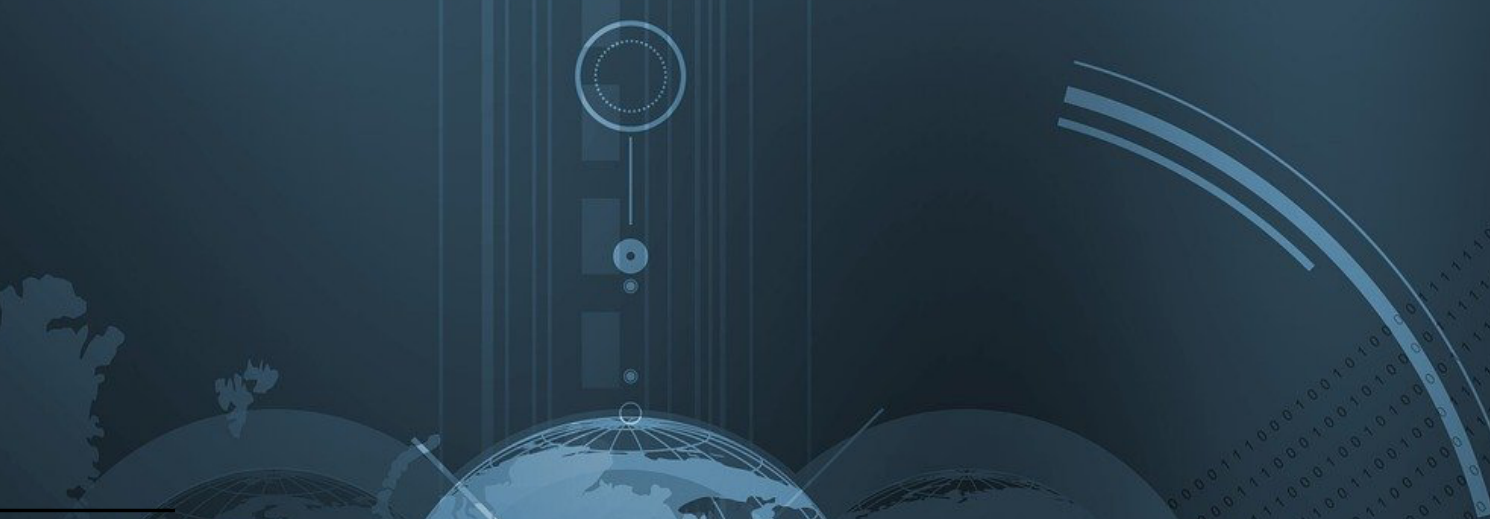

1 Versão parcialmente modificada dó trabalho apresentado e publicado nos ANAIS DO III ENCONTRO REGIONAL DE ENSINODE GEOGRAFIA: Práticas Educativas em Ensino de Geografia (re) criando documentos curriculares:16 e 17 de agosto de 2013, com pequenas atualizações.

2. Mestra em Ensino e História de Ciências da Terra pela Universidade Estadual de Campinas (Unicamp). Licenciada em Geografia pela Universidade Estadual de Feira de Santana (UEFS), camila_agm21@hotmail.com

3 Mestre em Ensino e História de Ciências da Terra pela Universidade Estadual de Campinas (Unicamp). Licenciado em Geografia pela Universidade Estadual de Feira de Santana (UEFS), rrb. anton@gmail.com

$4 \quad$ Doutora em Geografia (Universidade de Santiago de Compostela). Professora do curso de Geografia (UEFS). Coordenadora do Laboratório de Ensino de Geografia (LEG-UEFS). oasilva1@ uefs.br 


\section{INTRODUÇÃO}

Tecnologias da informação e comunicação possuem relações cada vez mais evidentes com os processos de ensino-aprendizagem e trabalho docente em geral. Atualmente, considerando-se o meio técnico-científico-informacional (SANTOS, 1996), a dinâmica dos smartphones e as necessidades cada vez maiores de ferramentas que desburocratizem processos e facilitem as atividades, recursos informáticos básicos devem ser valorizados pelos professores. Aqui, pretende-se discutir o Microsoft Word como um instrumento aliado do professor, capaz de facilitar diversos processos na atividade docente.

O presente texto é oriundo de uma oficina prática realizada com professores em formação. A motivação para a realização da oficina, em um projeto de extensão, adveio da constatação de que, apesar de ser um software popular, de fácil acesso, e considerado fácil por muitas pessoas, muitos alunos em formação nas licenciaturas da Universidade Estadual de Feira de Santana (UEFS) ainda apresentam uma série de dificuldades para realizar atividades simplórias na edição de textos, a exemplo de inserir notas de rodapé ou de organizar bem as figuras em textos por eles produzidos a fim de utilizarem em sala de aula.

É necessário reconhecer que há dificuldade com programas de edição de texto, ainda nos dias atuais, como pode-se observar no trabalho cotidiano na Licenciatura, ao requerer dos estudantes a organização de recursos didáticos para a inserção em planos de aula. Não é incomum que as atividades a serem impressas (textos adaptados, notícias de jornal, músicas, análise de mapas, questões de ENEM, atividades de fixação, avaliação e revisão) estejam mal formatadas, com espaços mal aproveitados, dentre outros aspectos.

Assumir que há certa dificuldade por parte de alguns alunos permite à Universidade auxiliá-los a superar as dúvidas, a partir de atividades formativas extracurriculares, como a realizada com o software Word, a fim de formar professores mais competentes nas habilidades requeridas à docência.

Evidencia-se o caráter formativo das oficinas/minicursos práticos e a assunção de que a Universidade não pode desconsiderar o fato de que nem todos tiveram/ têm acesso aos computadores até começarem o curso universitário, de modo a domina- 
rem plenamente suas diversas possibilidades de uso; ademais, há especificidades ao elaborar atividades escolares que nunca foram necessárias ao uso regular de muitos estudantes da licenciatura.

Ressalta-se ainda a troca de experiências entre discentes ministrantes de oficinas e aqueles que as frequentam, com vistas à autonomia, tão necessária a todo professor, como advertiu Freire (2004).

\section{CAMINHOS METODOLÓGICOS}

Este trabalho, de natureza qualitativa e caráter de pesquisa-ação, iniciou-se com uma breve caracterização bibliográfica dos processos envolvidos na temática, em consulta a autores que norteiam as discussões do uso de tecnologias em sala de aula, realizada em jornais, revistas científicas e em meios digitais, abrangendo publicações diversas em mídia digital ou em sites de pesquisa.

Em seguida, executamos a etapa mais prática do trabalho, com a realização de uma oficina ${ }^{5}$, executada e ministrada pelos autores deste trabalho, e coordenada pelo Laboratório de Ensino de Geografia (LEG) da UEFS. O público-alvo foi composto por estudantes de licenciatura em Geografia desta instituição.

Após a sua realização, efetuou-se a avaliação da oficina, sobressaindo-se respostas referentes aos êxitos da oficina e a importância daquele aprendizado. As informações obtidas foram tabuladas e, em seguida, o texto final foi elaborado.

\section{ENSINO DE GEOGRAFIA E NOVAS TECNOLOGIAS}

A Geografia é a ciência que estuda o espaço geográfico e as relações existentes nesse espaço. A partir dos estudos de tal ciência pode-se melhor compreender o mundo e as relações indissociáveis entre homem e natureza (SANTOS, 2008).

A Geografia escolar auxilia os alunos a desenvolverem o senso crítico e a conhecerem melhor o mundo em que vivem e as justificativas e fatores da atual organização do espaço em diferentes escalas - do local ao global. Para Callai a Geografia é a ciência que estuda, analisa e tenta explicar (conhecer) o espaço produzido pelo homem e, enquanto matéria de ensino, permite que o aluno "(...) se perceba como 
participante do espaço que estuda, onde os fenômenos que ali ocorrem são resultados da vida e do trabalho dos homens e estão inseridos num processo de desenvolvimento" (CALLAI, 1998, p. 56 apud CAVALCANTI, 2002, p. 13).

Para que a Geografia escolar seja ministrada levando em consideração o ponto de vista de Castrogiovanni (2007, p. 44), de uma disciplina que permite práticas interdisciplinares, é interessante que o professor planeje situações de ensino-aprendizagem que auxiliem os estudantes a utilizarem diferentes procedimentos de estudos como: observação, descrição, analogia e síntese para aprender a explicar, compreender e representar processos que constroem paisagens, territórios e lugares. Vale ressaltar que tais procedimentos servem para a espacialização de fenômenos e problematização de diversas situações e temas previstos na Base Nacional Comum Curricular de Geografia (BRASIL, 2017).

Para a realização de tais procedimentos o professor dispõe de ferramentas tecnológicas distintas e materiais bibliográficos que são também disponibilizados em meios digitais. Atualmente, algumas escolas dispõem de lousas digitais que podem tornar as aulas mais dinâmicas, por integrarem possibilidades de recursos como exibição de vídeos e/ou imagens (também visualizadas a partir de projetores chamados de 'Datashow' - mais comum nas escolas da Bahia).

Os programas computacionais que podem ser utilizados potencializam a autonomia docente à medida que permitem que o próprio professor elabore os seus vídeos, textos ilustrados, atividades de fixação com mapas, dentre outros.

A Base Nacional Comum Curricular (BRASIL, 2017) prevê que os recursos tecnológicos sejam fortemente aliados do estudante ao longo da sua formação e da sua vida prática. Ao processo educativo cabe, portanto, promover tais interações, inclusive considerando-se públicos notoriamente afastados de importantes recursos tecnológicos.

Entretanto, para que o professor efetive sua autonomia, é imprescindível que saiba interagir com as tecnologias e utilizá-las de maneira consciente e crítica. É preciso ainda que o docente acompanhe os avanços das tecnologias, principalmente as que podem ser utilizadas no ensino e que podem auxiliar os estudantes a se inserirem nas relações sociais do mundo moderno, haja vista que "[...] a base material da sociedade mudou, e com ela as relações sociais sofrem mudanças significativas 
- trata-se da sociedade em rede", discussão construída por Castells (2003 apud ALMEIDA, 2008, p. 33).

Para Toffer (1984 apud ALMEIDA, 2008, p. 33) "[...] a escola deve preparar as pessoas para a sociedade da Terceira Onda 6 - onde nenhuma economia poderá funcionar sem uma infraestrutura eletrônica envolvendo computadores".

É fácil compreender que este momento está em acelerada construção, embora existam diversas lacunas no acesso aos recursos e materiais tecnológicos mais modernos. Hinckel (2015, p. 66) discute a "sensação de imobilidade" vivenciada por professores e teóricos ao perceber que a educação básica não necessariamente acompanha as demandas atuais.

O Microsoft Word permite, também, uma aprendizagem ativa (BACICH e MORAN, 2018) mais eficiente ao apostar em tarefas básicas e avançadas no que tange ao letramento digital, produção e análise de textos, dentre outras.

Cabe ressaltar que não consideramos que o exercício da docência seja impossível sem o uso dos aparatos tecnológicos modernos. O que destacamos é que os novos docentes de Geografia devem ter um domínio amplo de todas as possibilidades tecnológicas, a fim de escolher de modo competente as formas de uso que the convier, emancipando-se quanto à produção de recursos didáticos, exercendo sua autonomia.

\section{O WORD APLICADO À ATIVIDADE DOCENTE}

A oficina intitulada "Word aplicado à atividade docente", por nós ministrada, fez parte do Ciclo de Oficinas 2013, uma iniciativa do Laboratório de Ensino de Geografia da Universidade Estadual de Feira de Santana. A oficina foi organizada para aprimorar conhecimentos sobre o software Word e sua aplicação na atividade docente de estudantes de licenciatura da Universidade Estadual de Feira de Santana e professores de educação básica.

A proposta da oficina se justificou pela constatação da necessidade de diversos estudantes da Licenciatura em Geografia da UEFS, bem como pela importância de saber utilizar adequadamente editores de texto para a produção de recursos didáti-

6 José Morin (2000) apresenta o livro "Os Sete Saberes Necessários à Educação do Futuro", prevendo diversas problemáticas discutidas atualmente. 
cos para o ensino de Geografia na educação básica - atividade corriqueira na vida profissional.

Cada vez mais é divulgada a inserção de aparato tecnológico nas redes de ensino (lousa digital, computadores, data show ou Tv-pendrive) e caso o docente planeje uma aula tendo como recurso didático um desses aparatos é necessário saber utilizá-los de forma correta.

Editores de texto como o Microsoft Word facilitam e introduzem recursos à produção de textos adaptados, avaliações escritas e listas de atividades, muito comuns na atividade docente. Os textos escritos pelos docentes facilitam a comunicação entre eles e os alunos. Ademais, uma apresentação textual didaticamente bem ajustada representa um convite à leitura.

Percebemos, através de observações indiretas em atividades de graduandos nas etapas de Estágio, que muitos licenciandos não conseguem organizar adequadamente os textos que levam às salas de aula, demonstrando uma série de dificuldades, que iam desde a inserção da logomarca da escola no cabeçalho da atividade à formatação de atividades para 'caberem' em poucas laudas, aproveitando bem os espaços do papel.

A oficina teve como público alvo os estudantes dos cursos de licenciatura da UEFS e professores da educação básica. Foram oferecidas vagas para 10 participantes com carga horária total de 8 horas divididas em dois encontros de 4 horas cada um, em turno vespertino. Os encontros aconteceram com o seguinte objetivo geral: capacitar os participantes para o uso em atividades docentes dos diferentes recursos do Microsoft Word, servindo para o professor de diversas formas, como elaboração de material didático e atividades para os alunos.

No primeiro encontro deu-se um enfoque maior para a importância da inserção das tecnologias na educação e suas potencialidades para o processo de ensino-aprendizagem, como também a exposição do passo-a-passo para a realização das funções básicas do software Word e debate de ideias para utilização do recurso na educação básica.

No segundo encontro partimos para a etapa mais prática, com a elaboração de uma atividade em que os participantes receberam, em papel impresso, uma si- 
mulação de avaliação escrita da educação básica com vários erros de formatação, e tiveram o desafio de digitar aquele material e deixá-lo com formatação correta, com o maior aproveitamento possível do espaço do papel (Figura 1).

Figura 1 - Atividade produzida pelos participantes da oficina

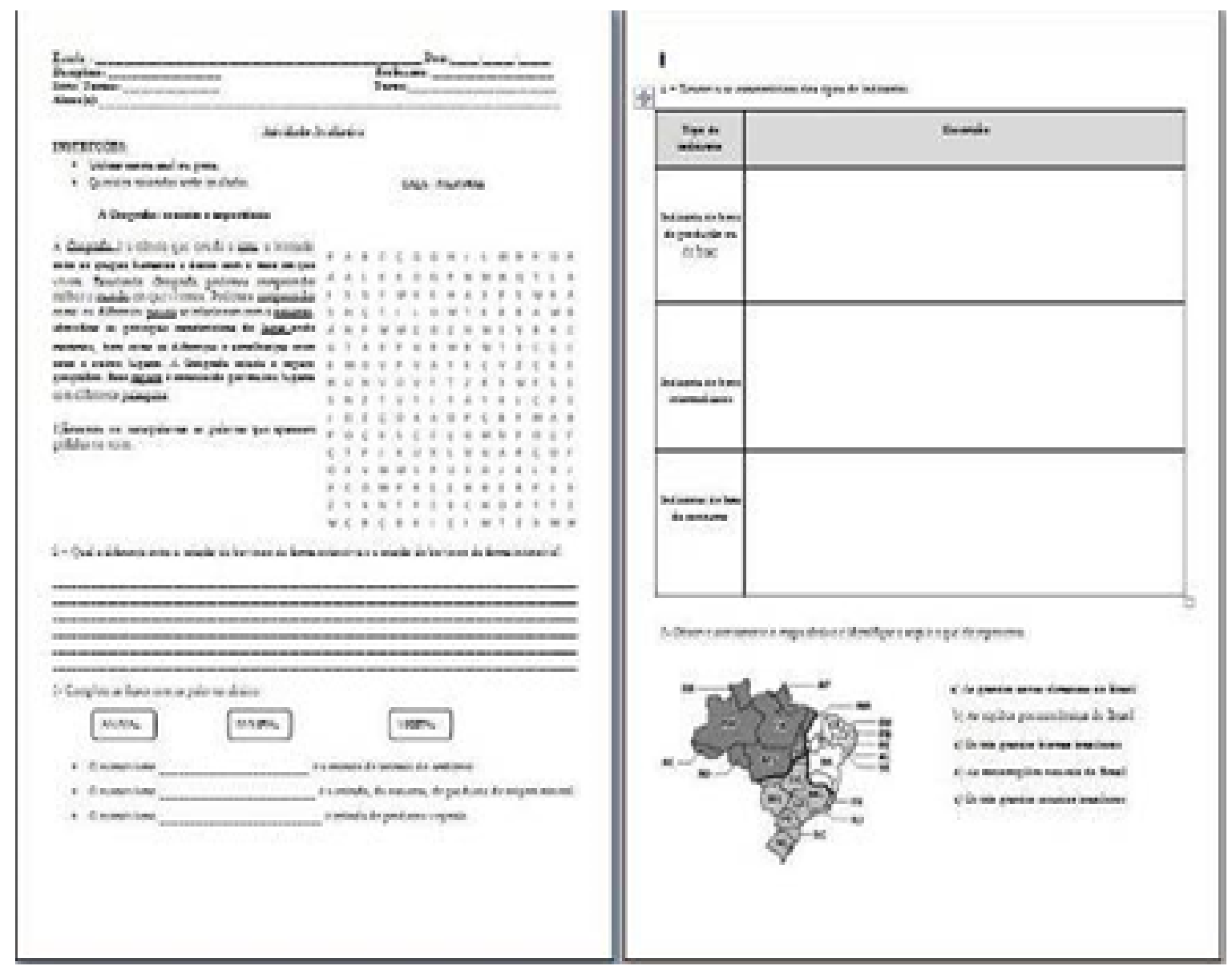

Fonte: Os autores.

Encerrada a oficina, perguntou-se aos participantes qual a importância da inserção de novas tecnologias na educação básica. Seguem, abaixo, as respostas mais significativas para esse trabalho:

Entrevistado 1 - "É muito importante para a capacitação de professores, no planejamento de atividades mais interessantes que contribuem para a aprendizagem dos alunos".

Entrevistado 2 - "Oferecem recursos ao professor e contribuem para uma aula mais didática, auxiliando na aprendizagem do aluno além de oferecer ao professor a elaboração de aulas mais práticas". 
Entrevistado 3 - "O ofício de ensinar está em constante mudança e é preciso adaptar-se às novas formas de produção do conhecimento, e o uso de novas tecnologias na sala de aula é fundamental, pois amplia as possiblidades do professor ensinar e do aluno aprender".

Entrevistado 4 - "É fundamental que o professor domine noções de informática a fim de facilitar, aprimorar e inovar em atividades para aluno".

Entrevistado 5 - "Importante, para que a escola se torne um ambiente agradável e próximo à realidade atual dos meios tecnológicos, que estão cada vez mais difundidos entre alunos de todas as idades. As tecnologias trazem dinamicidade às aulas e consequentemente maior interesse por parte dos alunos".

Entrevistado 6 - "Agiliza no tempo, na estética da atividade desenvolvida".

Evidenciou-se que os participantes compreendem a grande importância das novas tecnologias para o trabalho docente, além de indicarem a utilidade do aprimoramento no uso do software de edição de texto para o seu processo formativo e desempenho competente da docência e da elaboração de bons recursos didáticos.

\section{CONSIDERAÇÕES FINAIS}

Os avanços tecnológicos e informacionais experimentados pelas mais distintas sociedades nesse início de século XXI obriga os professores a uma constante atualização, a fim de desfrutar de todo o aparato disponível para a potencialização do processo de ensino-aprendizagem, bem como dos recursos disponíveis para facilitar o seu trabalho. É claro que é muito mais fácil organizar uma atividade escrita num editor de texto do que na antiga máquina de datilografar ou no mais antigo ainda carbono a ser copiado no mimeógrafo.

Vale ressaltar, entretanto, que em um país com má distribuição de renda e aplicação inadequada de recursos financeiros, onde a educação está à margem dos investimentos governamentais, estes recursos podem não estar disponíveis nas escolas ou, se estiverem não apresentarem bom funcionamento ou as características mais adequadas para seu uso. Há famílias que também não dispõem de computadores ou internet em casa, de modo que alguns estudantes dos cursos de licenciatura 
não entram na Universidade com o conhecimento no uso de programas básicos, como editores de texto, ou ainda, seu uso fora muito limitado ao longo da educação básica.

Destaca-se que a oficina ministrada de aplicação prática à atividade docente do editor de texto 'Microsoft Word' logrou excelente êxito, demonstrando que a formação de professores precisa considerar os diferentes níveis formativos nos quais os licenciandos chegam à Universidade, possibilitando ao longo de sua permanência na Universidade o acesso às tecnologias - desde as mais simplórias às mais complexas -, para a ampliação de suas competências, de modo a auxiliar o desenvolvimento de uma formação mais reflexiva e autônoma.

\section{REFERÊNCIAS}

ALMEIDA, Maria Cristina Alves de. As tecnologias da informação e comunicação (TIC), os novos contextos de ensino-aprendizagem e a identidade profissional dos professores. In: Revista Brasileira de Estudos Pedagógicos, Brasília, v. 89, n. 221, p. 30-46, jan./abr. 2008.

BRASIL. Base Nacional Comum Curricular. Ministério da Educação. Brasília: MEC, 2017.

BRASIL. Parâmetros curriculares nacionais: geografia. Secretaria de Educação Fundamental. Brasília: MEC/ SEF, 1998.

CASTROGIOVANNI, Antônio Carlos. Para entender a necessidade de práticas prazerosas no Ensino de Geografia na pós-modernidade. In: REGO, Nelson et al. (org). Geografia: práticas pedagógicas para o Ensino Médio. Porto Alegre: Artmed, 2007.

CAVALCANTI, Lana de Souza. Geografia e práticas de ensino. Goiânia: Alternativa, 2002.

COELHO, Lívia Andrade, et al. Não sei ler, logo não posso usar o computador? Alfabetização e letramento no contexto do EJA. In: ALENCAR, Raimunda Silva d'; et al. A educação (re)visitada: a velhice na sala de aula. Ilhéus, BA: Editus, 2012.

FREIRE, P. Pedagogia da autonomia: saberes necessários à prática educativa. São Paulo: Paz e Terra, 2004. 
MORIN, Edgar. Os Sete Saberes Necessários à Educação do Futuro. São Paulo: Cortez; Brasília: UNESCO, 2000.

SANTOS, Milton. A natureza do espaço: técnica e tempo, razão e emoção. 4. Ed. São Paulo: Hucitec, 2008. 


\title{
METODOLOGIA ATIVA:
}

\section{A HISTÓRIA EM QUADRINHOS COMO RECURSO PEDAGÓGICO NO ENSINO DE GEOGRAFIA}

\author{
MATEUS FRANGISCO LOPES \\ ANGÉLIGA VIEIRA DE SOUZA-LOPES
}

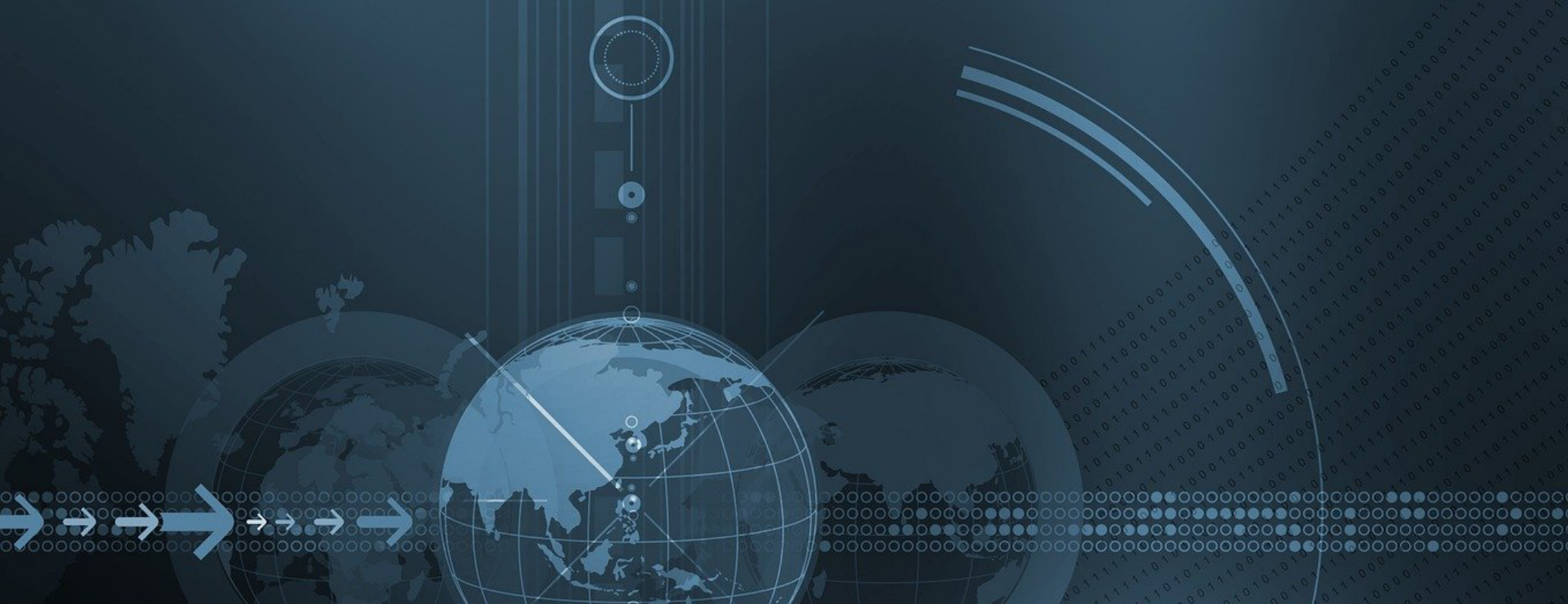

1 Mestrando no Programa de Pós-Graduação em Geografia da Universidade Federal de Alfenas (UNIFAL - MG) e Professor de Geografia no Ensino Médio no Instituto Samaritano de Ensino, Colégio São Francisco COC e Secretária de Educação do estado de São Paulo, licenciado e bacharel em Geografia, e-mail: mateusflopes.geo@gmail.com

2 Pós-doutoranda em Geografia Universidade Estadual Paulista UNESP - Rio Claro (SP), licenciada, bacharela, mestra e doutora em Geografia, e-mail: angelicaviso.geo@gmail.com 


\section{INTRODUÇÃO}

O presente trabalho apresenta parte das reflexões do estágio obrigatório da disciplina Estágio Supervisionado IV do Curso de Licenciatura em Geografia do Instituto de Geociências e Ciências Exatas - UNESP Campus de Rio Claro. O estágio de observação e de regência foi realizado em uma turma de segundo ano do ensino médio da Escola Estadual Marciano de Toledo Piza, localizada na cidade de Rio Claro - SP.

O estágio supervisionado foi composto por dez aulas de observação e três aulas de regência, os temas das regências foram O Mercado de Trabalho e A Segregação Socioespacial, para um melhor aprendizado, durante o estágio, buscou-se utilizar a história em quadrinhos (HQs) como recurso pedagógico para o ensino de geografia.

As HQs são consideradas como um meio de informações e de críticas sociais que proporcionam aos leitores a possibilidade de uma leitura geográfica de mundo, de espacialidade, de temporalidade e de cultura diversas (MELO; MEDEIROS; SILVA, 2013).

De acordo com Anselmo (1975), remonta-se a pré-história o surgimento das HQs, nas pinturas rupestres realizadas pelos homens das cavernas, as quais retratavam histórias por meio de imagens. Os hieróglifos retratados pelos egípcios, também são considerados como modo de comunicação por meio de imagens.

A partir da década de 1980, o ensino de Geografia no Brasil, proporciona uma substituição de uma Geografia escolar tradicional, caracterizada por ser mnemônica, descritiva e baseada no paradigma terra e homem, para uma Geografia escolar crítica, fundamentada na compreensão do mundo e do espaço geográfico da escala local à escala global. A realidade dos alunos e os problemas vivenciados de sua época e lugar deve ser considerado para despertar nos alunos um espírito crítico (VESENTINI, 2013).

A vivência cotidiana dos alunos deve ser associada aos estudos realizados em sala de aula. Conforme Moreira (2009), a ciência geográfica é a ciência do movimento, pertencente ao cotidiano, demonstrada na intimidade das condições de existência. O ensino de Geografia relaciona-se as práticas espaciais cotidianas, todos praticam, 
diariamente, um percurso geográfico, de casa para a escola, de casa para o trabalho, o que confirma a intimidade da geografia nas condições de existência humana.

Não é possível supor a escola como uma instituição independente ou autônoma em relação ao contexto sócio-histórico, não é licito supor que o que ocorre em seu interior não tenha articulação aos movimentos exteriores a ela. Claro está também que as relações escolares não implicam um espalhamento imediato daquelas extra-escolares. (AQUINO, 1996, p. 41)

Conforme Straforini (2004), as características do ensino de geografia tradicional são mantidas nas práxis pedagógicas por alguns docentes hodiernamente. Por meio da transmissão de conhecimento sendo realizada apenas por aulas expositivas, por ato de memorizar e decorar conteúdos, colocando o aluno na situação de mero agente passivo.

Com o uso de HQs busca-se romper com o ensino que coloca o aluno como simplesmente agente passivo relacionando a vivência do aluno com o tema trabaIhado, por meio desse recurso pedagógico como um meio de comunicação cultural e artístico e de linguagem visual.

\section{IMPORTÂNCIA DA HISTÓRIA EM QUADRINHOS NO ENSINO}

A inclusão de $H Q$ s no ensino realizou-se, principalmente, no final do século $X X$, sendo acentuado na década de 1970, com produções de HQs com propósitos educacionais (VERGUEIRO, 2014). A utilização de HQs como recurso pedagógico torna-se significativo devido à satisfação dos alunos por esse modelo de leitura, pela ilustração aliada ao texto, o que proporciona uma melhor comunicação, com ampliação do vocabulário e aperfeiçoamento da leitura. "E sem dúvida, os quadrinhos representam hoje, no mundo inteiro, um meio de comunicação de massa de grande penetração popular" (Vergueiro, 2014, p. 7).

O uso de HQs como ferramenta de ensino proporciona uma relação de aproximação entre a vida cotidiana, o conhecimento cotidiano do aluno, com o conhecimento científico proposto pela escola.

Desse modo, há que se destacar sua potencialidade para levar o aluno a perceber, por exemplo, a geografia no cotidiano, para fazer a ponte entre seu conhecimento cotidiano e o científico, para problematizar o conteúdo escolar e partir de outras linguagens e de outras formas de expressão. (Cavalcanti, 2002, p. 83) 
A utilização de HQs no ensino, de acordo com Rama e Vergueiro (2012), é diversificada, tendo como "único limite para seu bom aproveitamento em qualquer sala de aula é a criatividade do professor e sua capacidade de bem utilizá-los para atingir seus objetivos de ensino" (RAMA; VERGUEIRO, 2014, p. 20). As HQs devem ser adequadas ao calendário do curso, ao planejamento da disciplina, sem distinção as outras propostas didáticas e linguagens, sendo usadas como recurso para o desenvolvimento da escrita e da leitura:

Os quadrinhos não podem ser vistos pela escola como uma espécie de panaceia que atende a todo e qualquer objetivo educacional, como se eles possuíssem alguma característica mágica capaz de transformar pedra em ouro. Pelo contrário, deve-se buscar a integração dos quadrinhos a outras produções das indústrias editorial, televisiva, radiofônica, cinematográfica etc., tratando todos como formas complementares e não como inimigas ou adversárias na atenção dos estudantes. (RAMA; VERGUEIRO, 2014 p.21)

Conforme Vesentini (2013), o ensino crítico da geografia não se limita apenas a renovação do conteúdo, mas é importante incorporar novos temas relacionados às lutas sociais e também valorizar determinadas atitudes e habilidades. O uso de HQs no ensino de geografia vincula-se aos novos temas e na valorização de atitudes, como capacidade de crítica e na luta contra preconceitos, pois:

No bojo da renovação e dos novos caminhos trilhados, dialogar com as áreas do conhecimento, ler geografia com base em textos variados das diferentes ciências, da mídia, do imaginário popular, etc. é algo enfatizado com as mudanças dos anos 80 em especial. (REICHWALD JR, 2004, p. 69)

De acordo com Vergueiro (2004), a explicação do uso de HQs em sala de aula é motivada devido aos HQs fazerem parte da vida cotidiana dos alunos; aos diferentes códigos que proporcionam uma maior aprendizagem; os diversos temas das publicações sendo possível utilizá-los em todos os níveis escolares; a incorporação da linguagem gráfica às linguagens oral e escrita e o desenvolvimento do pensamento lógico. O uso de HQs possibilitará aos alunos "ampliarem a capacidade de observação e de expressão, ao estimular a fantasia, ao despertar o prazer estético, senso de humor e a crítica, tornando o ato de ler uma atividade prazerosa e contribuindo para estabelecer o hábito saudável da leitura" (Silva, 2004, p. 24). 
Foram realizadas três aulas de regência, a primeira aula teve como tema o "trabalho e o mercado de trabalho, com a participação feminina no mercado de trabalho" e segunda aula sobre a "segregação socioespacial e a exclusão social". De acordo com Tabela 1.

\section{Tabela 1 - Plano de Aula}

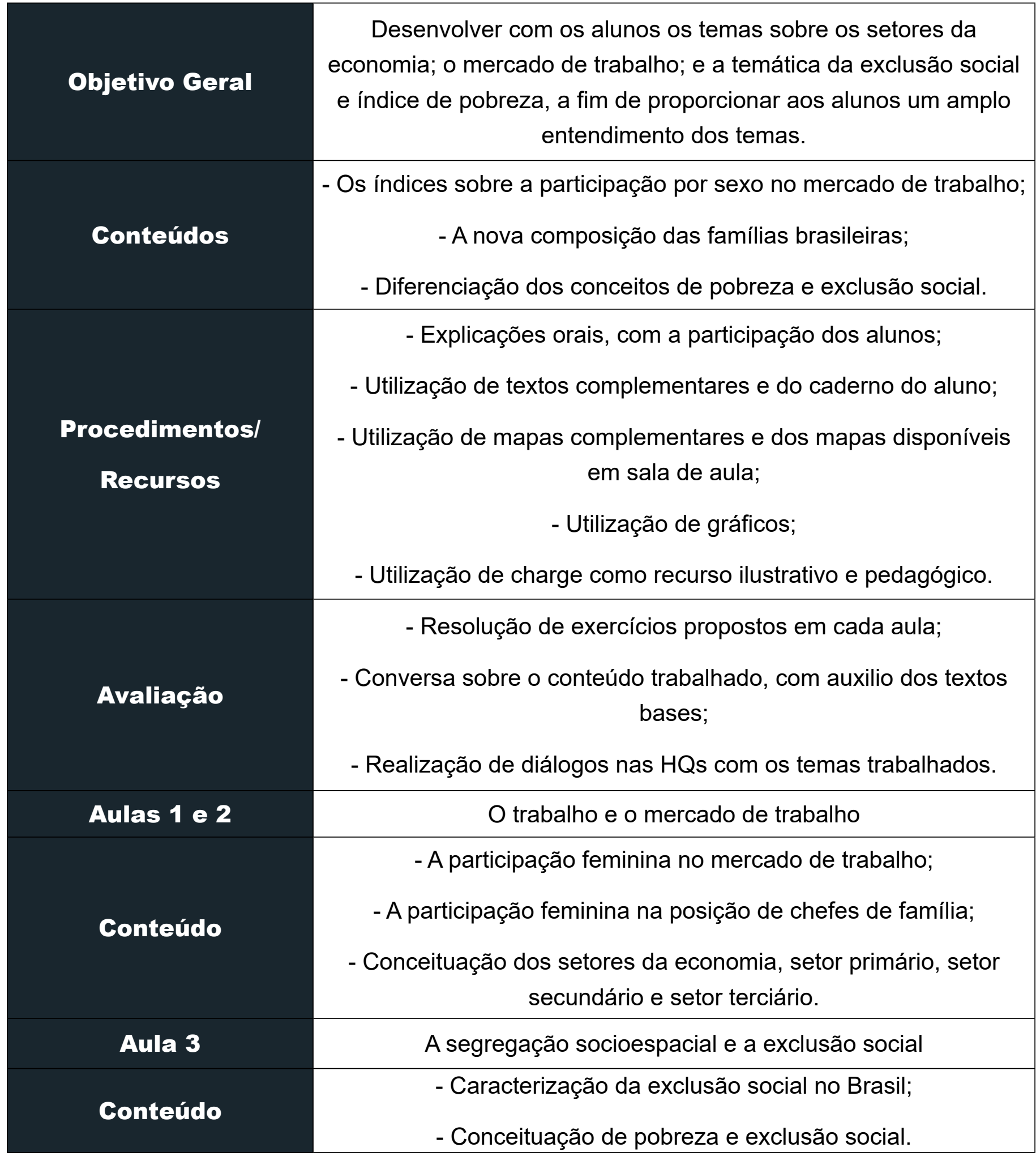


Realizamos as aulas dialogadas, com questionamentos a fim de proporcionar um pensamento reflexivo aos alunos e utilizamos textos base que foram entregues aos alunos, com conteúdo dos temas trabalhados em cada aula.

Após terminarmos as explicações, pedimos que os alunos se reunissem em duplas, para trabalharmos os exercícios propostos, e para realizarem a atividade em história em quadrinhos, ao final de cada aula.

Acreditamos que devido a nossa explicação no início da aula, dizendo aos alunos que havíamos preparado a aula e que gostaríamos que eles participassem e realmente aprendessem o conteúdo, fomos correspondidos. Os alunos realizaram a atividade, discutiram sobre o assunto, nos pediram esclarecimento sobre a atividade. Ao toque do sinal, os alunos se despediram e saíram. Com a saída dos alunos, arrumamos as carteiras e fomos surpreendidos pelas palavras da professora titular "vocês foram muito bem, parabéns".

O planejamento, a intencionalidade, a construção coletiva, são muito importantes para alcançar, atingir os fins desejados. Assim como LUCKESI (1992, p. 115), acreditamos que:

O ser humano age em função de construir resultados. Para tanto, pode agir aleatoriamente ou de modo planejado. Agir aleatoriamente significa "ir fazendo as coisas", sem ter clareza de onde se quer chegar; agir de modo planejado significa estabelecer fins e construí-los através de uma ação intencional. Os fins, sem a ação construtiva, adquirem a característica de fantasias inócuas; a ação aleatória, sem fins definidos, desemboca no ativismo.

Ao término das aulas, sentimos que havíamos cumprido as nossas propostas de aulas, nos sentimos realizados em termos dado as aulas que elaboramos e, principalmente, pela participação e atenção dos alunos.

(...) é na relação professor-aluno que se instaura, de fato, o processo de ensino-aprendizagem. Por isso, sem medo de errar, podemos afirmar que as chances de sucesso ou insucesso do trabalho pedagógico se deve, em grande parte, à qualidade dessa relação. (ROSA, 1995, p.63)

Durante as aulas utilizamos diversas charges e HQs como recurso pedagógico, então a proposta de avaliação foi à elaboração de diálogos em HQs prontos. Foram entregues aos alunos dois fragmentos de HQs com os diálogos em branco para serem preenchidos, a atividade foi realizada em duplas. 
Quando a última dupla entregou a atividade, discutimos com os alunos sobre as possíveis maneiras de preenchimento do HQ. Nesse momento houve uma participação completa dos alunos, todos responderam como tinham preenchido os diálogos.

Após terminarmos a conversa sobre a atividade, nos despedimos deles, explicamos que esse era o último dia que estaríamos com eles, dizemos que foi um prazer lecionarmos para eles, e agradecemos a professora titular da classe, por ter permitido que estagiássemos com ela.

Nesse momento os alunos foram muito gentis conosco, dizendo que gostariam que nós continuássemos dando aula para eles, não queriam que fossemos embora. Com isso percebemos o quanto esse estágio foi importante para nós, e que realmente valeu a pena toda nossa dedicação em preparamos às aulas. As HQs fornecidas aos alunos são formadas por história da Turma da Mônica (SOUSA, 2002) e da Mafalda (QUINO, 2003), conforme as figuras 1 e 2, respectivamente.

Figura 1: História em Quadrinhos Sem Diálogo - Mulher no Mercado de Trabalho

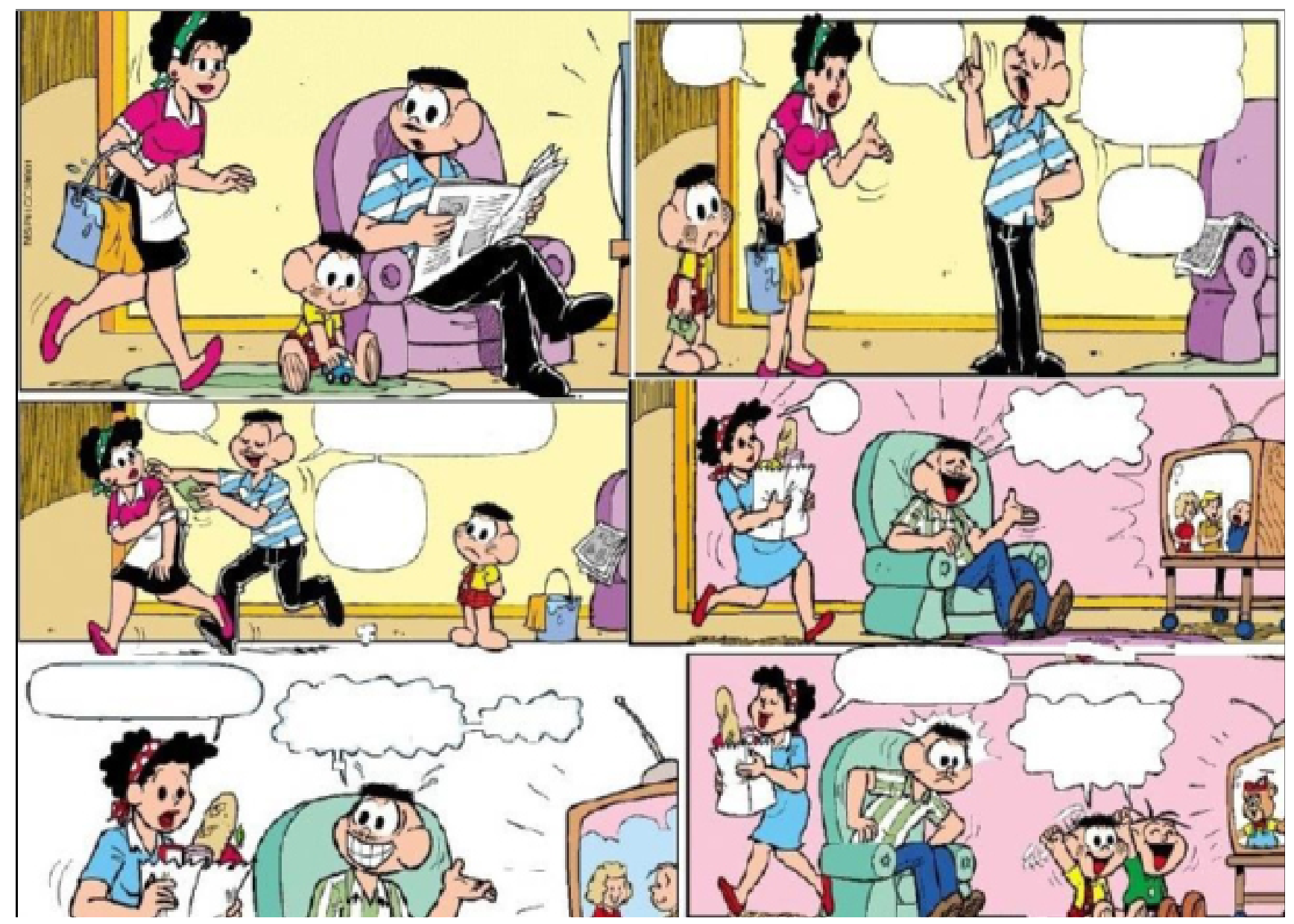

Fonte: Maurício de Sousa Produções Ltda. 2002. 
Figura 2: História em Quadrinhos Sem Diálogo - Desigualdade Social
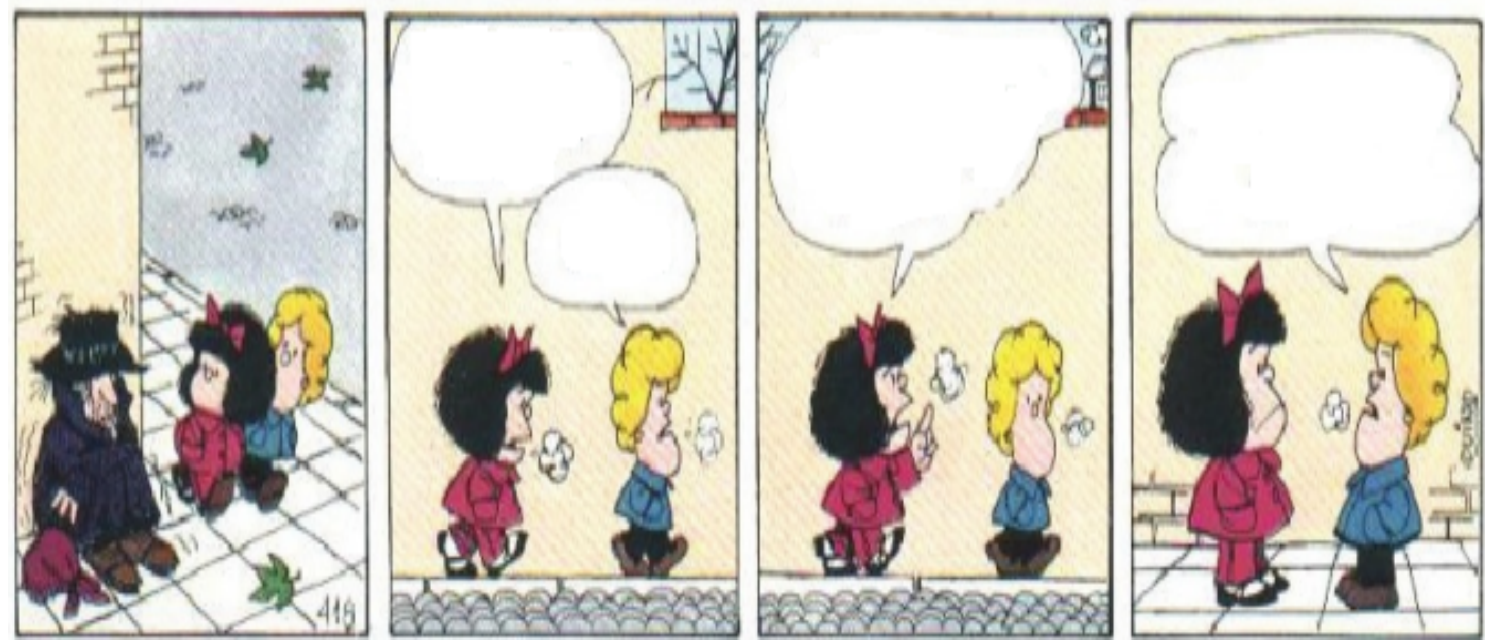

Fonte: Quino, 2003.

A atividade referente à figura 1 teve como preenchimento dos diálogos propostas como o enfrentamento da mulher em busca de uma colocação profissional em detrimento do machismo. Apontamentos em relação à dupla ou tripla jornada de trabalho das mulheres, as quais além de trabalharem no mercado de trabalho, também são responsáveis pelos trabalhos domésticos e cuidados com os filhos e maridos. Os alunos foram criativos, relacionando os quadrinhos com situações do cotidiano. Os alunos também abordaram a temática relacionada ao cotidiano de um casal, representando um marido grosseiro e uma mulher submissa, referindo-se a essa realidade de submissão vivenciada por muitas mulheres.

Para a figura 2, os alunos relacionaram a temática da exclusão social, com a pobreza, a discriminação e a violência. Alguns alunos elaboraram questionamentos referentes à escolaridade e ao êxodo rural no entendimento da questão da pobreza. $A$ questão da exclusão, da humilhação e do destrato aos pobres também foi abordada.

\section{CONCLUSÃO}

Por meio do acolhimento que tivemos com a turma do $2^{\circ}$ ano do ensino médio, percebemos que cabe a nós, professores buscarmos novos caminhos para a aprendizagem, segundo Rosa (1995, p.17) "desfazer idealizações ou falsas imagens para, no lugar, colocar uma ideia mais precisa do seu papel profissional, é tarefa que se impõe aos educadores". 
Os critérios utilizados para a avaliação, realizadas pelos alunos, foram a coesão textual, a criatividade e a pertinência ao tema, detalhados pelas HQs. Essas atividades foram realizadas, em sua maioria, com muita criatividade e senso crítico em relação aos temas propostos.

As HQs foram utilizadas como um recurso pedagógico, por entendermos o importante potencial pedagógico dessa ferramenta, articulando a arte, a literatura e, nesse trabalho, a geografia. Por meio das HQs os alunos tiveram a possibilidade de expressar suas vivências e conhecimentos por meio de uma forma de expressão não convencional a sala de aula.

Cabe aos professores, proporcionarem aos seus alunos, algo realmente significativo. "A educação é um terreno multidisciplinar, sem predomínio de uma ou outra ciência, mas tendo claramente delineada sua função socializadora" (CUNHA, 1995, p.52). Que a escola seja um local para a aprendizagem, e sendo assim, que lá não apenas os alunos, mas também os professores, estejam em constante mudança, em constante desenvolvimento, num processo de humanização, de apropriação do conhecimento científico produzido pela humanidade.

\section{REFERÊNCIAS}

ANSELMO, Z. A. Histórias em quadrinhos. Petrópolis - RJ: Vozes, 1975.

AQUINO, J. G. A desordem na relação professor-aluno: indisciplina, moralidade e conhecimento. In: AQUINO, J. G. (org). Indisciplina na escola: alternativas teóricas e práticas. São Paulo - SP: Summus, 1996.

CAVALCANTI, L.S. Geografia e educação no cenário do pensamento complexo e interdisciplinar. Boletim Goiano de Gografia, 22 (2), jul/dez 2002. p. 123-136.

CUNHA, M.V. A Educação dos educadores. Campinas - SP: Mercado de Letras, 1995.

LUCKESI, C. C. Planejamento e Avaliação na Escola: articulação e necessária determinação ideológica. Artigo da Série Ideias, n. 15. São Paulo: FDE, 1992. p.115125.

MELO, K. C.; MEDEIROS, A. F.; SILVA A. A. Uma Linguagem alternativa no ensino escolar: as histórias em quadrinhos na mediação do ensino e aprendizagem da 
geografia. Ateliê Geográfico, Goiânia-GO, v. 7, n. 1, p.260-283. 2013.

MOREIRA, Ruy. O que é geografia. São Paulo - SP: Brasiliense, 2009. QUINO, J. L. Toda Mafalda. São Paulo: Martins Fontes, 2003.

RAMA, A.; VERGUEIRO, W. (Org.). Como usar as histórias em quadrinhos em sala de aula. São Paulo - SP: Contexto, 2014.

REICHWALD JR., G. Leitura e escrita na geografia ontem e hoje. In: NUNES, C. B. et al (Orgs.). Ler e escrever - compromisso de todas as áreas. 6. ed. Porto Alegre - RS: Ed. da UFRGS, 2004.

ROSA, S.S. Construtivismo e Mudança. São Paulo - SP: Editora Cortez, 1995.

SILVA, J. R. F. O espaço geográfico expresso nas histórias em quadrinhos: uma experiência com Chico Bento. 2004. 111 f. Dissertação (Mestrado em Geografia) Universidade Estadual Paulista - UNESP, Presidente Prudente, SP, 2004.

SOUSA, M. Turma da Mônica. São Paulo - SP: Maurício de Sousa Produções, 2002.

STRAFORINI, Rafael. Ensinar geografia: o desafio da totalidade-mundo nas séries iniciais. 2. ed. São Paulo - SP: Annablume, 2004.

VERGUEIRO, W.Histórias em quadrinhos e ensino: uma dupla cada vez mais dinâmica. Papiro, ano 5, nº 20, jul/.ago./set., 2004.

VERGUEIRO, W. Quadrinhos e educação popular no Brasil: considerações à luz de algumas produções nacionais. In: VERGUEIRO, W.; RAMOS, P. (Org.). Muito além dos quadrinhos: análises e reflexões sobre a 9a arte. São Paulo - SP: Devir, 2009.

VERGUEIRO, W. Uso das HQS no ensino. In: RAMA, A.; VERGUEIRO, W. (Org.). Como usar as histórias em quadrinhos em sala de aula. São Paulo - SP: Contexto, 2014.

VESENTINI, José William. Realidades e perspectivas do ensino de geografia no Brasil. In: VESENTINI, José William (Org.). $O$ ensino de geografia no século XXI. São Paulo - SP: Papirus, 2013. 


\title{
"LUGAR", UM APORTE TEÓRICO-METODOLÓGICO PARA O ENSINO DE GEOGRAFIA
}

\author{
RAFAEL RIBEIRO DOS SANTOS \\ MARIA IDELMA VIERRA D'ABADIA \\ LOÇANDRA BORGES DE MORAES
}

MARY ANNE VIEIRA SILVA
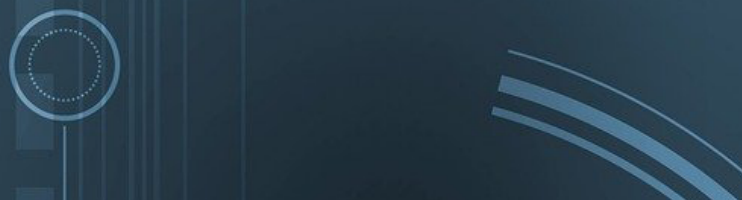

1 Mestrando em Ciências Sociais e Humanidades pelo Programa de Pós-Graduação em Territórios e Expressões Culturais no Cerrado (PPG-TECCER) da Universidade Estadual de Goiás (UEG). Graduado em Geografia (licenciatura) pela UEG, Unidade Universitária de Anápolis - Ciências Socioeconômicas e Humanas (UnUCSEH). E-mail: rafaelribeiro.geografia@gmail.com

2 Pós-doutora em Geografia pela Universidade Federal do Paraná (UFPR). Docente efetiva e pesquisadora da Universidade Estadual de Goiás UEG, onde atua no curso de Geografia (licenciatura) e no Programa de Pós-Graduação em Territórios e Expressões Culturais no Cerrado (PPG-TECCER), ambos lotados na Unjẩäle Universitária de Anápolis - Ciências Socioeconômicas e Humanas (UnUCSEH).E-mail: marią:dabadia@ueg.br

a) $3-$ Doutora em Geografia pela Universidade de São Paulo (USP). Docente efetiva, pesquisadora e coordenadora setorial do curso de Geografia (licenciatura) da Universidade Estadual de Goiàs (UEG), Unidade Universitária de Anápolis - Ciências Socioeconômicas e Humanas (UnUCSEH). E-mail: locandra.moraes@ueg.br

$4 \quad$ Pós-doutora em Geografia pela Universidade Federal de Juiz de Fora (UFJF). Docente efetiva e pesquisadora da Universidade Estadual de Goiás UEG, onde atua no curso de Geografia (licenciatura) e no Programa de Pós-Graduação em Territórios e Expressões Culturais no Cerrado (PPG-TECCER), ambos lotados na Unidade Universitária de Anápolis - Ciências Socioeconômicas e Humanas (UnUCSEH). E-mail: mary.silva@ueg.br 
"[...] o objetivo do ensino de Geografia é o de estudar o lugar para compreender o mundo. O lugar não simplesmente como uma referência local, mas como uma escala de análise necessária para compreender os fenômenos, que acontecem no mundo, mas são localizados temporal e territorialmente em um determinado local" (CAVALCANTI, 2010a, p. 376).

\section{INTRODUÇÃO}

O conceito geográfico de lugar se apresenta por meio de uma noção vasta e densa de sentido e significado, trata-se de uma categoria de análise que possui diferentes interpretações conceituais e apresenta uma rica gama de potencialidades de estudo. Na perspectiva do ensino de Geografia, o lugar transcende a sua própria dimensão assente nos princípios locacionais, pois, na medida em que os conteúdos são elucidados nesse viés, permitem também compreensões relacionadas a outras categorias da ciência geográfica. De acordo com Bento (2015, p. 191, grifo da autora) "a categoria lugar possibilita ao professor trazer a realidade dos jovens escolares para as aulas sem se prender aos limites do concreto imediato [...]".

Assim, buscamos correlacionar os conceitos de "lugar" e "prática docente", associando-os ao processo de ensino e aprendizagem de Geografia. Na primeira seção enfatizamos as contribuições proporcionadas pelo lugar, quando ligado à prática docente. Na segunda, o lugar é tratado, diretamente, no contexto das aulas de Geografia, isto é, na perspectiva escolar, dos conteúdos ministrados na Educação Básica (Ensino Fundamental I e II e Ensino Médio).

\section{O LUGAR PARA APRENDER E/OU ENSINAR GEOGRAFIA}

A polissemia do conceito geográfico de lugar permite a multiplicidade de aprendizados, pois, garante à prática docente possibilidades de empregar diferentes tipos de sentidos, ou mesmo aguçá-los, para além de ponto de referência e ou localização. Essa pluralidade de conhecimento, a partir dos espaços, refletem marcas históricas de uma sociedade, (de)marcam temporalidades, expressam culturas, identidades e fenômenos diversos. Nesse contexto, Callai (2005, p. 228-229) afirma que 
apenas do mapa, ou pelo mapa, embora ele seja muito importante. É fazer a leitura do mundo da vida, construído cotidianamente e que expressa tanto as nossas utopias, como os limites que nos são postos, sejam eles do âmbito da natureza, sejam do âmbito da sociedade (culturais, políticos, econômicos).

Desse modo, a partir da reflexão exposta por Callai (2005); para se realizar uma leitura espacial, no intuito de compreender o mundo, é preciso que se observem as situações relacionais entre os sujeitos, a forma como eles se manifestam, ocupam e interagem entre si, isto é, como se dá o processo de socialização. Assim, o indivíduo passará a entender que a paisagem vista ao seu redor é fruto dessa relação de coexistências sociais. Logo, é no cotidiano, nesse imbricamento de sentidos e emoções, prazeres e desprazeres que a vida se evidencia, acontece. Conforme expõe Silva (2007), tratar sobre o cotidiano de determinada localidade nos conduz a análises que confrontam diferentes situações, a vasta rede de sociabilidade estabelecida pelos moradores instiga-nos a pensar os motivos que perpassam por esses elos fomentados por diferenças e similaridades. Portanto, de acordo com Moreira e Hespanhol (2007, p. 48), "o lugar pode ser compreendido como uma construção social, fundamentado nas relações espaciais diretas, no cotidiano e na articulação entre a cooperação e o conflito".

O lugar refere-se a uma forma importante e particular do reconhecimento das singularidades formuladas a partir da totalidade, ele ainda "[...] expressa a dimensão espacial, que se traduz pela organização do território" (CALLAI; CAVALCANTI; CASTELLAR, 2012, p. 85). Ou seja, o conceito de lugar traduz o espaço por meio de sua especificidade, é uma maneira de exprimir a lógica na perspectiva do território, ao mesmo tempo, sem deixar de ser algo vinculado às particularidades, às individualidades de cada sujeito que compõe o espaço, criando e recriando-o. Para tanto, o lugar é representativo e marcado, sobretudo, pelas formas de apropriação, conforme exemplifica Silva (2007).

É no lugar que se tem dinamicidade, ocorre [à] experiência vivida, cheia de conteúdos, onde se faz e refaz o cotidiano, onde acontece a reprodução da vida [,] (privada, lazer, trabalho). Diante da unicidade aparente, falseia-se o peso do lugar, espaço privilegiado das manifestações, das solidariedades, do cotidiano. Reconhece que é no lugar que a vida se realiza em todas suas dimensões (SILVA, 2007, s./p., grifos da autora). 
Sobre o processo de ensino e aprendizagem, Callai, Cavalcanti e Castellar (2012), afirmam que para o emprego do lugar, faz-se importante que a criança passe a conhecê-lo desde cedo. Conhecer o espaço de vivência, fazer com que os alunos possam visualizá-lo possibilita um aprendizado mais significativo, sobretudo concebendo o cotidiano onde vivem. A partir disso, nota-se que a "Geografia nos leva a conhecer e compreender o mundo da vida - esse mundo próximo de nós, mas também o que está distante, que é trazido a nós no dia-a-dia pela informação ou por interesses particulares ou sociais [...] (CALLAI; CAVALCANTI; CASTELLAR, 2012, p. 84).

Á medida que o lugar passa a ser um conceito mais representativo, sobretudo no âmbito do ensino e aprendizagem de Geografia,descortina-se as múltiplas realidades contidas nos conteúdos ministrados, a partir do cotidiano dos alunos. No entanto, essa não é uma tarefa fácil, são muitos desafios impostos ao professor para superar em sua prática docente e enfrentar os desconhecimentos dos cotidianos. Diante do exposto, Cavalcanti (2010), aponta que esse profissional deve conseguir selecionar e ministrar os conteúdos previstos no currículo, mas ao mesmo tempo esclarecer aos seus alunos a relevância desses conteúdos, despertar neles o interesse para estudar uma determinada temática correlacionada a vida cotidiana.

É válido ressaltar os desafios enfrentados pelo professor em sua atuação diária, dentre os quais se destacam os baixos salários (remuneração incompatível com o trabalho desempenhado) e as intensas jornadas de trabalho. Claro que tais questões não podem agir como fator preponderante diante da atuação do professor, mas esses empecilhos, ao longo do caminho, geram desconforto, impactam de forma significativa a sua atuação docente.

Nessa perspectiva, de tornar o ensino-aprendizagem mais significativo, Castellar (2010, p. 47) afirma que isso só irá acontecer a partir do momento em que a "[...] referência do conteúdo estiver presente no cotidiano da sala de aula, quando se considerar o conhecimento que a criança traz consigo, a partir da sua vivência". Ou seja, é fazer o aluno sentir-se um personagem importante/determinante no processo de ensino-aprendizagem, o fazendo perceber e se perceber em meio aos conteúdos. Portanto, cada vez mais, os pesquisadores do ensino de Geografia insistem nessa questão do ensino significativo, pois para eles, a Geografia, em especial, tem um 
papel muito importante, seja no âmbito das ciências humanas ou das disciplinas de modo geral. "A Geografia, sendo a disciplina que estuda a sociedade a partir da abordagem espacial, analisa o espaço que apresenta a concretização/materialização das relações que acontecem entre os homens e destes com a natureza" (CALLAI, 2010, p. 17). Ou seja, a Geografia é e deve continuar sendo uma ciência atenta e preocupada com as dinâmicas e interações que ocorrem dentro do espaço, com a ação do homem sobre esse e os impactos gerados por essas atitudes nesse meio.

Diante dessa perspectiva da Geografia como uma ciência que desperta/aguça os sentidos, a reflexão (KAERCHER, 1996), nota-se a importância da realização de uma abordagem do ensino de forma multiescalar. Isto é, um ensino que leve a uma associação dos conteúdos em suas múltiplas instâncias de abrangência e complexidade, conectando o local ao global e vice-versa, tomando em consideração as potencialidades de cada uma dessas escalas. Sobre esse tipo de abordagem, Cavalcanti (2010, p. 6) contribui afirmando que

A abordagem multiescalar tem como suporte o entendimento da necessária
articulação dialética entre escalas locais e globais na construção de racio-
cínios espaciais complexos, como se requer hoje para o entendimento da
realidade. O global, visto como conjunto articulado de processos, relações e
estruturas do espaço tem um significado específico e peculiar em cada lugar;
mas esse lugar não pode ser apreendido completamente se não se fizer uma
articulação de seu significado com a totalidade da qual faz parte. Busca-se
entender os fenômenos na relação parte/todo, concebendo a totalidade dinâ-
mica, no jogo de escalas.

Assim, diante do exposto pela autora, é possível compreender que as escalas, tanto global, quanto local, precisam estar interligadas dentro de uma lógica processual para ocorrer à construção de um raciocínio. Isso posto, o professor, ao procurar partir de um ensino significativo para seus alunos deve buscar estabelecer uma articulação/associação dos conteúdos, valorizando suas particularidades, e buscando trazê-los para a sua realidade, àquela vivida e manifestada por seus alunos em sala de aula.

Todavia, isso não significa negar ou supervalorizar uma ou outra escala de análise, mas articulá-las, é possibilitar ao aluno visualizar um determinado fenômeno, tal como o da segregação, não só na região sudeste do país, especialmente, Rio de 
Janeiro e São Paulo, pois, sumariamente, são esses os exemplos trazidos para eles por meio dos livros didáticos e da mídia. Trata-se de fazer que eles mesmos percebam que a segregação pode ocorrer na cidade onde moram, ou mesmo demonstrar, numa esfera local, como esse processo acontece.

Nessa dinâmica, não se trata somente de concatenar o global (macro) ao local, mas demonstrar aos alunos que as suas questões do cotidiano também podem ser visualizadas numa perspectiva macro de entendimento. A partir de suas experiências alguns alunos podem compreender a existência de determinadas coisas que ocorrem no seu dia-a-dia e, por algum motivo, não se fazem presentes no de outras pessoas. A sagacidade do professor poderá fazer os alunos perceberem e entenderem como isso tudo funciona, fazer como que, mesmo depois sozinhos, eles consigam realizar suas próprias articulações por meio do que aprenderam. Claro, ao longo desse processo pode ser que haja alguns conteúdos limitantes à prática adotada pelo professor, pois nem todos, necessariamente, são de fácil associação ao cotidiano.

É nesse contexto que o ensino significativo se manifesta, passa a ser algo comum na rotina dos alunos, e proporciona a essas crianças, jovens e adultos, inseridos nas escolas, a possibilidade de pensar, visualizar e refletir sobre a sua própria realidade, dando a ela uma conotação geográfica. Porém, tomar o lugar apenas como ponto de partida a fim de os alunos terem interesse pelos conteúdos e depois, simplesmente abandonar tal perspectiva, não faz o menor sentido; ao contrário, tal prática deve-se manter como uma constante, nos mais diversos conteúdos ministrados (CAVALCANTI, 2010).

Também sobre a relevância do lugar no processo de ensino e aprendizagem de Geografia, Callai (2010a) afirma que ao considerar a vivência do aluno, seu cotidiano vivido, percebido e concebido, um lugar de constantes alterações; o professor e a escola passam a compreender o lugar como um fundamento de aprendizagem. Dessa maneira, ainda conforme a autora, aprender Geografia sob as aparas do cotidiano, o qual pode e deve ser incorporado a gama de conteúdos que são ministrados; revela a ligação de cada sujeito (aluno) com o seu mundo, o espaço de onde ele se origina, onde manifesta as suas individualidades, seus anseios e desejos. Para, além disso, o lugar e o cotidiano contribuem para a promoção de uma formação cidadã. 
Assim, é válido ressaltar que ao tratar do ensino de Geografia, a partir do lugar vivido dos/pelos alunos, da experiência desses sujeitos, não estamos nos referindo estritamente à sua casa. Conforme Callai (2010a), ao tratar desse espaço vivenciado, especialmente pelos jovens, não estamos nos limitando a casa, ou a vizinhança, seu entorno, mas sim aos espaços onde o jovem tece suas experiências. O lugar tratado aqui diz respeito aos tantos lugares em que os jovens experienciam a sua própria condição juvenil, essa fase marcada pelas inquietações, pelas buscas do "novo", encarar o desconhecido. Nesse sentido, estamos nos referindo aos espaços de (re)produção da vida, onde esses jovens estabelecem relações, convivem com outros jovens, fundam um sentimento de pertencimento, criam territorialidades, sejam essas duráveis ou não, isso tudo em um contínuo processo de descobertas, afirmações, um (re)criar constante de suas próprias identidades.

Na dimensão do vivido, Callai (2004) afirma que o lugar é um espaço produzido a partir do resultado da vivência dos sujeitos, das ações realizadas, da apropriação, das formas de lazer praticadas. O lugar é a ocupação de um dado espaço e em um momento específico da história, que nas trocas cotidianas dão sentido a essa fração do espaço, configurando o lugar, o vivido, as histórias cheias de marcas, das quais trazem em cada uma um pouco do "eu", do sujeito. Ainda de acordo com a autora, esse lugar gera uma identidade coletiva, resultado de uma organização de um grupo e suas particularidades, no entanto, é preciso que o indivíduo construa a sua identidade pessoal e singular, passando-se assim da perspectiva do espaço vivido para o espaço percebido.

Compartilhando desse entendimento de lugar, Lisboa (2007, p. 29) contribui ao afirmar que "o lugar pode ser entendido como a parte do espaço geográfico efetivamente apropriada para a vida, área na qual se desenvolvem as atividades cotidianas ligadas à sobrevivência e às diversas relações estabelecidas pelos homens". Ou seja, um espaço geográfico demarcado por meio das relações de afetividade instituídas e desenvolvidas entre os homens e desses com seu ambiente/espaço, seu lócus de vivência. Chega-se assim, à perspectiva do espaço concebido, à sua formulação teórica. 
Para contribuir, conceitualmente, sob a perspectiva de análise do lugar, Santos; Costa e Kinn (2010, p. 48) afirmam: "somos o lugar onde nos fizemos, as pessoas com quem convivemos, a história de que participamos, a memória coletiva que carregamos". Assim, tomando o contexto do lugar e a sua densidade enquanto uma categoria geográfica verifica-se a sua importância no âmbito do ensino de Geografia; sua complexidade, e ao mesmo tempo, clareza de potencializar um ensino mais significativo, próximo da realidade dos estudantes. Essa concepção do lugar imputa e fomenta um aluno que vai para a escola com uma bagagem cultural oriunda de sua vivência. Nessa linha, todos os alunos carregam consigo uma carga cultural muito forte, a qual se manifesta em suas múltiplas relações e trocas, seja com seus pares (colegas) ou com o ambiente (escola, sala de aula). Desse modo, o professor precisa saber lidar com essa situação em sala de aula, logo, a próxima seção é justamente pautada nessa perspectiva, no âmbito da Geografia, mais especificamente da Geografia escolar.

\section{O LUGAR NA GEOGRAFIA ESCOLAR DA ESCOLA BÁSICA}

Na medida em que o lugar já foi conceituado na discussão empreendida pela seção anterior, passamos agora a refletir sobre a Geografia escolar. É nesse contexto que surgem alguns questionamentos: no que consiste a Geografia escolar? Quais os fundamentos dessa subárea da Geografia? Como é e onde ela se faz presente? Quais os sujeitos no ensino de Geografia? Para tanto, buscaremos discorrer sobre essa perspectiva da Geografia, por vezes negada ou reduzida diante de outras subáreas de análises geográficas.

Para entender o que é a Geografia escolar5, partimos da definição de Cavalcanti (2017, p. 28) para quem a Geografia escolar é uma gama de saberes "[...] estrutura-

$5 \quad$ Antes de começar a desenvolver o que é a Geografia escolar, é preciso deixar claro quando e como ela surge, bem como o contexto em que ela se insere no Brasil. Para isso nos amparamos em Cavalcanti (2008) realizando um breve contexto histórico. A Geografia brasileira (acadêmica e escolar) foi institucionalizada no século XX, isso se deu através da Sociedade Brasileira de Geografia (SBG), Instituto Brasileiro de Geografia e Estatística (IBGE), Universidade de São Paulo (USP), assim como outras instituições que fizeram parte desse processo de institucionalização, o qual está atrelado diretamente ao seu ensino. Conforme estudos empreendidos por pesquisadores da história da Geografia, mesmo antes dessa ser um campo de formação em nível superior, essa matéria (Geografia) já era ensinada em escolas, ou seja, a Geografia escolar precede a institucionalização da própria Geografia acadêmica. Contudo, tanto a Geografia acadêmica, quanto a Geografia escolar, tem suas histórias atreladas uma à outra, uma influência mútua e direta entre elas. 
dos e veiculados na prática docente, com o objetivo de compor o objeto da formação escolar dos alunos da escola básica, para que eles, por sua vez e como cidadãos, possam também compreender e analisar o mundo" em seus múltiplos aspectos e espacialidades. Nessa perspectiva, ainda na análise de Cavalcanti (2008, p. 28),

[...] a geografia escolar é o conhecimento geográfico efetivamente ensinado, efetivamente veiculado, trabalhado em sala de aula. [...] a geografia escolar não se ensina, ela se constrói, ela se realiza. Ela tem um movimento próprio, relativamente independente, realizado pelos professores e demais sujeitos da prática escolar que tomam decisões sobre o que é ensinado efetivamente.

Diante disso, entende-se a Geografia escolar como a Geografia produzida no ambiente escolar, dentro de sala de aula. Trata-se de uma disciplina que não se ensina, mas deve ser norteada pela construção, sobretudo se levar em consideração as suas particularidades, a forma como pode, ou mesmo como é ensinada. A Geografia escolar então diz respeito a um campo do conhecimento geográfico "[...] que representa um conjunto de instrumentos simbólicos, conceitos, categorias, teorias, dados, informações e procedimentos sobre o espaço geográfico, constituído em sua história [...]" (CAVALCANTI, 2006, p. 34).

Callai (2010, p. 22) contribui para essa discussão ao afirmar que a função da Geografia escolar é a de

[...] desenvolver um pensamento espacial que se traduz em: olhar o mundo para compreender a nossa história e para interpretar o mundo da vida. Interessa conhecer o mundo interligando os problemas do lugar com as demandas globais. Este lugar em que está cada um de nossos alunos ou mesmo aquele em que estamos nós como um local que se insere em uma escala social de análise que tem no seu contraponto principal o global.

Para a autora, a Geografia escolar serve para despertar/aguçar nos alunos uma visão do espaço que os levem a pensar sobre esse mesmo espaço, não como ele se apresenta meramente, mas entendê-lo como fruto de uma série de transformações históricas e geográficas, impactando-o (in)diretamente, fazendo-o ser da forma como o vemos nos dias de hoje. Não obstante, Callai (2010) realiza uma conexão dessa questão da Geografia escolar com o lugar, afirmando que ele deve ser alinhado às questões apresentadas no contexto global. Isso posto, evidencia-se então a necessidade da Geografia escolar buscar, em sua realização, através da figura do professor, 
ser para os alunos não somente mais uma disciplina do currículo, mas algo que os levem a refletir sobre o espaço, sobre o lugar em que estão inseridos.

Contudo, essa práxis escolar não se consolida isoladamente, para isso, é preciso que haja uma conexão com outro eixo da Geografia, o qual é sempre colocado em paralelo à Geografia escolar, trata-se da Geografia acadêmica6. Essa última refere-se ao conhecimento geográfico produzido e estruturado no âmbito das instituições de ensino superior que possuem departamentos de Geografia, havendo a existência então de uma formação e especialização de geógrafos. Nessa lógica, é possível compreender que a diferença entre essas duas perspectivas geográficas se dá a partir dos interesses/finalidades de cada uma, assim como a linguagem usada em cada uma dessas instâncias, sobretudo em função do público alvo.

A Geografia escolar em seu processo formativo, bem como em sua finalidade converge para uma construção de cidadania por meio dos conteúdos e das reflexões despertadas. Conforme Cavalcanti (2008) essa prática ocorre em virtude da (re)construção de conhecimentos, habilidades, valores, e comportamentos que levem os estudantes a terem a oportunidade de compreender o espaço/mundo onde vivem e atuam, a partir do momento em que estão inseridos em uma escola, nesse ambiente dotado de representações. Como aponta Dayrell (1996), trata-se de um ambiente sociocultural. Para Cavalcanti (2008, p. 81) "o exercício da cidadania na sociedade atual, por sua vez, requer uma concepção, uma experiência, uma prática comportamentos, hábitos, ações concretas [...]". Assim, desponta-se a ideia de uma educação, de um ensino de Geografia voltado para a cidadania. Portanto, é válido entender melhor o que significa essa questão, para que assim se possa compreender como as atuais formas de ensino coadunam ou não com a preposição de uma "educação para a cidadania".

6 Do ponto de vista de Cavalcanti (2017, p. 28) a Geografia acadêmica consiste nos "[...] conteúdos que compõem as diferentes disciplinas dos cursos de formação em nível superior, ou seja, é o conjunto de conhecimentos formulados por geógrafos investigadores, com referências na história da ciência em suas diferentes matrizes teórico-epistemológicas. É resultado da produção de teorias, categorias/conceitos, postulados, sistemas e classificações que são disponibilizados aos estudantes, futuros professores, para ajuda-los a formarem compreensões e análises do mundo na perspectiva espacial". 
Para Callai (2001, p. 136) a educação para a cidadania diz respeito a

[...] um desafio para o ensino e a Geografia é uma das disciplinas fundamentais para tanto. O conteúdo das aulas de Geografia deve ser trabalhado de forma que o aluno construa a sua cidadania. $E$ muito se tem falado em educação para a cidadania, mas de maneira, muitas vezes, irreal e inalcançável, burocrática, ligada ao positivismo e com soluções técnicas, definida num ou em vários objetivos, que no mais das vezes consideram o sujeito-estudante deslocado do mundo em que vive, como se fosse um ser neutro e abstrato.

A Geografia, se analisada através da representatividade ofertada, principalmente devido aos seus conteúdos, veicula-se como uma ciência que faz com que as pessoas passem a refletir e se articular melhor a fim de se posicionarem de forma mais complexa e reflexiva. Ou seja, trata-se de uma área do conhecimento que instiga e colabora com os sujeitos no exercício de sua criticidade. Logo, a Geografia passa a ser, na esteira das ciências humanas, uma disciplina ímpar que garante aos alunos, gradativamente, a construção de sua cidadania. No entanto, como adverte Callai (2001), há uma tendência negativa em fazer os alunos tomarem consciência de sua cidadania de maneira utópica, distanciando esses de suas realidades, promovendo uma dimensão abstrata, dispensável. Para ser possível pensar em uma educação cidadã, que leve os alunos a quererem saber e conhecer mais, se deve levar em consideração o próprio aluno, não se pode deixar de lado as suas particularidades, sua essência, a dimensão do vivido, seus motivos e suas necessidades.

Na medida em que se evidencia a Geografia escolar, bem como a necessidade de uma educação cidadã como fruto desse processo de ensino, é necessário lembrar que isso tudo só será possível se houver um professor minimamente competente para lidar com toda essa complexidade em sala de aula. Para alcançar essa competência, Callai (1995; 2011), assim como Cavalcanti (2017), afirmam a necessidade de o professor atuar como pesquisador, alguém que se reinvente, busque se atualizar, que não limite seu conteúdo, a sua ânsia de aprender, de adquirir novos saberes; os quais são fundamentais para o professor atender as demandas imputadas por sua profissão; afinal, pesquisar também é um exercício de autoavaliação, de olhar para sua prática docente. 
Nesse contexto, a Geografia escolar possui grande sentido e significado, pois busca possibilitar aos alunos um aprendizado que os levem a pensar o espaço (CALLAI, 2010a). A leitura realizada por crianças e jovens (público em geral que compõe o grupo de alunos) poderá contribuir para sua educação geográfica. Conforme sua capacidade crítica de olhar o espaço vai se acentuando, eles passam a compreender, de forma prática, as dinâmicas que ocorrem no mesmo, as quais o alteram de modo singular. Isso pode, futuramente, ocasionar a formação de cidadãos com mais consciência e interesse em atuar sobre o espaço, mas uma atuação que seja inteligente, crítica, que fuja das barreiras reducionistas, as quais muitos insistem manter, mesmo nos dias atuais.

Para tanto, a escola, em seu cotidiano, precisa abrir os portões para que o cotidiano de seus alunos possa adentrar e se manifestar dentro desse ambiente. Assim, esse espaço será plural, acolhedor, aconchegante para as pessoas que circulam diariamente em suas dependências (CALLAI, 2010a). Para isso acontecer, não é necessária uma infraestrutura de ponta, nada complexo, mas sim que a escola (consideram-se aqui as pessoas que fazem parte dessa instituição) seja motivadora e estabeleça inter-relações, no intuito da promoção de uma aprendizagem, sendo o professor o agente interlocutor/mediador durante esse processo educativo (CALLAI, 2010a).

Na busca de conectar o lugar à escola, desse estreitar de relações, Callai (2010a, p. 34, grifos da autora) aponta que

Um caminho para se estudar o lugar pode ser pelo trabalho com os conceitos de grupo-espaço e tempo, pois é a possibilidade de definir os parâmetros para este aprendizado que requer que a criança se olhe, se perceba e saiba se situar no mundo. Os grupos dos quais as crianças passam a fazer parte são social e historicamente construídos. Eles existem situados num tempo e num espaço que marcam sua existência e são, pode-se dizer, a matéria-prima a ser estudada. Desenvolver esses conceitos é, portanto, fundamental para o aprendizado pretendido, fazendo com que as crianças consigam perceber a identidade, que é territorial, mas socialmente construída, e, a partir disso, reconheçam seu pertencimento a um mundo no qual estão vivendo e onde estão suas origens. Esse sentimento de pertencimento é importante na vida dos homens, para que eles possam se reconhecer como sujeitos de sua própria existência e consigam exercer sua cidadania. 
Diante do exemplo apresentado pela autora, percebe-se que tornar o ensino significativo, próximo da realidade dos alunos não depende de meios revolucionários, não exige grandes gastos. Para que o lugar seja manifestado, especialmente na Geografia escolar, na sala de aula é preciso que o professor se reinvente, na busca de refletir sobre maneiras que tornem os conteúdos (sendo alguns desses, tradicionalmente, exaustivos pela complexidade existente) em algo que faça sentido, que leve os alunos a pensar sobre a sua experiência. Ao tomar essa dimensão significativa, o lugar de vivência dos alunos torna-se potencializador das aulas de Geografia, uma ferramenta didática.

\section{CONSIDERAÇÕES FINAIS}

Com base na exposição feita, o que se conclui, de maneira geral e provisória; sobretudo por compreender esse tema como algo a ser melhor e continuamente explorado, é a relevância apresentada pela categoria lugar, seja para a ciência geográfica em si, ou, mais especificamente, no ensino de Geografia. Em sua pluralidade teórica o lugar perpassa diferentes linhas e perspectivas do raciocínio geográfico. No âmbito do ensino, é ainda algo a ser explorado por parte dos professores, especialmente em função do potencial teórico e prático apresentado para as aulas de Geografia.

Portanto, trazer o lugar do aluno para a sala de aula significa aproximar esse sujeito da sua realidade, fazer com que sua vivência passe a constituir aquilo que ele está estudando e que o conteúdo visto nos materiais didáticos rompa a barreira do global e se conecte a dimensão local. A expectativa é que esses movimentos poderão fazer o aluno perceber as múltiplas questões existentes no seu meio e passem então a refletir sobre a necessidade e as possibilidades de transformá-las.

\section{REFERÊNCIAS}

BENTO, Isabella Peracini. Ensino e aprendizagem em Geografia e os motivos dos alunos: a aposta do/no lugar. Boletim Goiano de Geografia, Goiânia, v. 35, n. 1, p. 177-193, jan./jun. 2015. Disponível em: https://repositorio.bc.ufg.br/xmlui/handle/ ri/11149. Acesso em: 20 ago. 2018. 
CALLAI, Helena Copetti. O conhecimento geográfico e a formação do professor de Geografia. Revista Geográfica de América Central, Costa Rica, número especial EGAL 2011, p. 1-20, jul./dez. 2011. Disponível em: https://www.redalyc.org/ html/4517/451744820036/. Acesso em: 2 nov. 2018.

CALLAI, Helena Copetti. A formação do professor de Geografia. Boletim Gaúcho de Geografia, Porto Alegre, n. 20, p. 39-41, dez., 1995. Disponível em: https://www.seer. ufrgs.br/bgg/article/viewFile/38032/24535. Acesso em: 02 nov. 2018.

CALLAI, Helena Copetti. A Geografia e a escola: muda a Geografia? Muda o ensino?. Terra Livre, São Paulo, n. 16, p. 133-152, jan./jun. 2001. Disponível em: http://www. agb.org.br/publicacoes/index.php/terralivre/article/view/353. Acesso em: 20 ago. 2018.

CALLAI, Helena Copetti. Aprendendo a ler o mundo: a Geografia nos anos iniciais do Ensino Fundamental. Cad. Cedes, Campinas, v. 25, n. 66, p. 227-247, mai./ago. 2005. Disponível em: http://www.scielo.br/pdf/\%0D/ccedes/v25n66/a06v2566.pdf. Acesso em: 20 fev. 2019.

CALLAI, Helena Copetti. O estudo do lugar como possibilidade de construção da identidade e pertencimento. In: CONGRESSO LUSO-AFRO-BRASILEIRO DE CIÊNCIAS SOCIAIS, 8., 2004, Coimbra. Anais [...]. Coimbra: Universidade de Coimbra - Centro de Estudos Sociais, Faculdade de Economia, s/p, 2004. Disponível em: https://www.ces.uc.pt/lab2004/pdfs/HelenaCallai.pdf. Acesso em: 2 nov. 2018.

CALLAI, Helena Copetti. A Geografia ensinada: os desafios de uma educação geográfica. In: MORAIS, Eliana Barbosa Marta de.; MORAES, Loçandra Borges de (orgs.). Formação de Professores: conteúdos e metodologias no ensino de Geografia. Goiânia: NEPEG, 2010, p. 15-37. Disponível em: http://nepeg.com/livros/formacao-de-professores-2/. Acesso em: 8 nov. 2018.

CALLAI, Helena Copetti. Escola, cotidiano e lugar. In: BUITONI, Marísia Margarida Santiago (coord.). Geografia: ensino fundamental. Brasília: Ministério da Educação - Secretaria de Educação Básica, 2010a, p. 25-42. Disponível em: http://www.cdcc. usp.br/cda/PARAMETROS-CURRICULARES/ME-Ensino-Medio/2011_geografia_ capa.pdf\#page=25. Acesso em: 2 nov. 2018.

CALLAI, Helena Copetti; CAVALCANTI, Lana de Souza; CASTELLAR, Sonia Maria Vanzella. O Estudo do Lugar nos anos iniciais do Ensino Fundamental. Terra Livre, São Paulo, v. 1, n. 38, p. 79-98, jan./jun. 2012. Disponível em: http://www.agb.org.br/ 
publicacoes/index.php/terralivre/article/view/461. Acesso em: 2 nov. 2018.

CASTELLAR, Sônia Maria Vanzella. Educação geográfica: formação e didátca. In: MORAIS, Eliana Barbosa Marta de.; MORAES, Loçandra Borges de (orgs.). Formação de professores: conteúdos e metodologias no ensino de Geografia. Goiânia: NEPEG, 2010, p. 39-57. Disponível em: http://nepeg.com/livros/formacao-de-professores-2/. Acesso em: 8 nov. 2018.

CAVALCANTI, Lana de Souza. A Geografia e a realidade escolar contemporânea: avanços, caminhos e alternativas. In: SEMINÁRIO NACIONAL: CURRÍCULO EM MOVIMENTO, 1., 2010, Belo Horizonte. Anais [...]. Belo Horizonte, p. 1-16, 2010. Disponível em: http://portal.mec.gov.br/docman/dezembro-2010-pdf/7167-3-3-geografia-realidade-escolar-lana-souza/file. Acesso em: 2 nov. 2018.

CAVALCANTI, Lana de Souza. Concepções teórico-metodológicas da Geografia escolar no mundo contemporâneo e abordagens no ensino. In: SANTOS, Lucíola Licínio de Castro Paixão; et. al. (orgs). Convergências e tensões no campo da formação e do trabalho docente. Belo Horizonte: Autêntica, 2010a, p. 368-391.

CAVALCANTI, Lana de Souza. Ensino de Geografia e demandas contemporâneas: práticas e formação docentes. In: ALVES, Adriana Olivia; KHAOULE, Anna Maria Kovacs. A Geografia no cenário das políticas públicas educacionais. Goiânia: C\&A - Alfa \& Comunicação, 2017, p. 15-32.

CAVALCANTI, Lana de Souza. Bases teórico-metodológicas da Geografia: uma referência para a formação e a prática de ensino. In: CAVALCANTI, Lana de Souza (org.). Formação de Professores: concepções e práticas em Geografia. Goiânia: E.V, 2006, p. 27-49. Disponível em: http://nepeg.com/livros/formacao-do-professor/. Acesso em: 13 out. 2018.

KAERCHER, Nestor André. A Geografia é nosso dia-a-dia. Boletim Gaúcho de Geografia, Porto Alegre, n. 21, p. 109-116, ago., 1996. Disponível em: https://seer.ufrgs. br/bgg/article/viewFile/38639/26361. Acesso em: 20 ago. 2018.

LISBOA, Severina Sarah. A importância dos conceitos da Geografia para a aprendizagem de conteúdos geográficos escolares. Revista Ponto de Vista, Viçosa, v. 4, p. 23-35, jan./dez. 2007. Disponível em: http://www.coluni.ufv.br/revista-antiga/docs/ volume04/importanciaConceitosGeografia.pdf. Acesso em: 2 nov. 2018.

MOREIRA, Erika Vanessa; HESPANHOL, Rosângela Aparecida de Medeiros. O lu- 
gar como uma construção social. Formação: São Paulo, v. 2, n. 14, p. 48-60, jul./dez. 2007. Disponível em: http://revista.fct.unesp.br/index.php/formacao/article/view/645. Acesso em: 2 nov. 2018.

SANTOS, Rosselvelt Jose dos; COSTA, Cláudia Lúcia da; KINN, Marli Graniel. Ensino de Geografia e novas linguagens. In: BUITONI, Marísia Margarida Santiago (coord.). Geografia: ensino fundamental. Brasília: Ministério da Edicação - Secretaria de Educação Básica, 2010, p. 25-42. Disponível em: http://www.cdcc.usp.br/cda/ PARAMETROS-CURRICULARES/ME-Ensino-Medio/2011_geografia_capa.pdf\#page=25. Acesso em: 2 nov. 2018.

SILVA, Mary Anne Vieira. Cotidiano e lugar: interpretações conceituais numa leitura geográfica para uma prática de ensino. In: ENCONTRO ESTADUAL DE DIDÁTICA E PRÁTICA DE ENSINO, 2, 2007, Anápolis. Anais [...]. Anápolis: Universidade Estadual de Goiás, s/p, 2007. Disponível em: http://www2.unucseh.ueg.br/ceped/edipe/ anais/lledipe/pdfs/cotidiano_e_lugar.pdf. Acesso em: 2 nov. 2018. 


\section{O USO DA IMAGEM VISUAL COMO ARTEEATO DIDÁTICO-PEDAGÓGICO PARA AS AULAS DE GEOGRAFIA}

RICARDO SANTOS DE ALMEIDA

RAPHAEL FONTES CLOUX

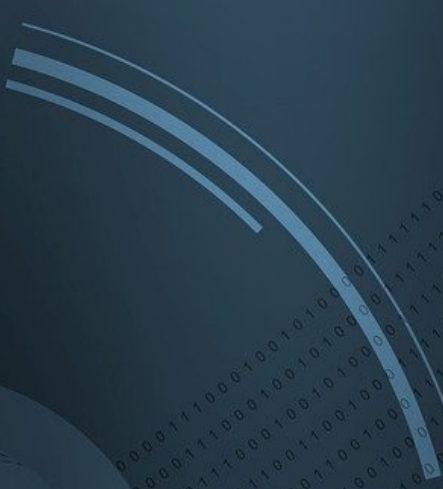

1 Docente do Instituto Federal de Ciência e Tecnologia de Alagoas Campus Marechal Deodoro e da rede pública municipal de Porto CalvolAL. Doutorando em Geografia pela Universidade Federal de Santa Maria, Estudiante del Doctorado en Ciências de la Educación pela Universidad Interamericana. Maceió/AL, Brazil, ORCID: https://orcid.org/0000-0003-1266-2557, Lattes: http:// lattes.cnpq.br/5955679764505968, ricardosantosal@gmail.com

2 Docente da Universidad Interamericana. Doutor em Desenvolvimento Regional e Urbano pela Universidade Salvador. Asunción, Paraguay. ORCID: https://orcid.org/0000-0001-9469-1188, Lattes: http://lattes.cnpq.br/1316344490441710, raphaelcloux2@yahoo.com.br/ 


\section{INTRODUÇÃO}

Este estudo objetiva-se por evidenciar a importância do uso da imagem visual como artefato didático-pedagógico, pois ela contribui para o fortalecimento de valores, atitudes, comportamentos e saberes produzindo efeitos significativos no processo de ensino-aprendizagem contribuindo, portanto, para a formação de leitores críticos à realidade que nos cerca. Portanto, estabelece-se a discussão sobre o uso da imagem visual como artefato didático-pedagógico para as aulas de Geografia em turmas dos mais variados níveis e modalidades de ensino.

Nesta discussão, nos consubstanciaremos em Carlos $(2008,2011,2012)$ a partir de seus estudos sobre a importância do ato de ver, sobre a imagem como objeto do conhecimento e sobre sua presença na proposta pedagógica freiriana, bem como as fontes originais em Freire $(1967 ; 1981 ; 1989)$ sobre a educabilidade do olhar e a pedagogia crítica da visualidade, e em Cavalcanti (1998) e Santos (2014) no que diz respeito a importância da leitura e compreensão das dinâmicas e metamorfoses socioespaciais para além do visível. Sendo assim, este estudo analítico-argumentativo permite inspirar os profissionais docentes da Geografia a utilizar de modo mais aprofundado e consciente a imagem visual nas aulas.

Ao nos objetivarmos evidenciar a imagem visual como produtora de conhecimentos geográficos se fazem necessárias algumas revisitações sobre nossas reais funções sociais estabelecidas ao longo de nossas formações no âmbito da licenciatura e que se perpassam pelos atos de ensinar e aprender. Embasados na perspectiva de Puntel (2007, p. 89) nós "educadores, podemos estimular, motivar, convencer os nossos educandos de que aprender é tão necessário quanto nutrir-se", ou seja, nós junto a eles devemos ser conscientes de nossos atos e desejos, pois somos capazes de produzir conhecimentos e devemos ir além do mero ato de ensinar e de aprender.

Ao enfatizarmos a imagem visual como produtora de conhecimento geográfico, devemos, portanto, estabelecer que seu uso deve ultrapassar a condição de mera ilustração contribuímos com estudos da pedagogia da imagem, pois nos comprometemos aqui em estimular "a compreensão, análise e investigação crítica do mundo codificado nas múltiplas formas de signos e linguagens visuais" (CARLOS, 2008, p. 15). Este fato é evidenciado a partir do momento em que dispomos de uma cultura da 
visualidade embora careçamos de ferramentas cognitivas para lidar com a imagem, ou seja, estimular pela educação sua discussão, interpretação, análise e leitura da configuração iconográfica e semiótica elidindo sobretudo com o analfabetismo visual e às tramas ideológicas dos grupos sociais dominantes que as utiliza para a reprodução de seus interesses sociopolíticos e econômicos.

Para que o uso da imagem visual seja estabelecido, se faz necessário conhecermos as regras de funcionamento, do uso coerente e de sua leitura e este processo se perpassa pela educação inserindo-se em diferentes processos de ensino-aprendizado associados ao tema gerador, preferencialmente. Aqui declaramos que este processo deve se estabelecer respeitando-se a percepção sensorial, a percepção mental e a percepção textual, ou seja, cabe-nos no processo educativo estimular a capacidade de expressão do observador sobre o mundo apreendido percebendo os signos, suas codificações e decodificações indagando-se sobre qualquer imagem através das seguintes indagações: "o que é? O que significa? Como age? O que comunica? Quais são seus efeitos prováveis - seus efeitos inimagináveis?" (CARLOS, 2008, p. 34).

É preciso problematizarmos, questionarmos, provocarmos, confrontarmos o que está posto em nossa contemporaneidade, ou na leitura e análise de outros tempos e espaços, para que possamos ao mediar o conhecimento curricular tornar os educandos sujeitos reflexivos sobre os que os cerca partilhando-lhes os sentidos e aprendizados rompendo com os universos em que se cercam cada professor que ao construir "para si mesmo uma espécie de jurisprudência particular, feita ao longo de anos ao sabor dos erros e acertos" (GAUTHIER, 1998, p. 187) cerceia sua própria importância e a evolução dos que dele precisam no processo de ensino-aprendizado.

\section{A IMAGEM VISUAL É UMA RUPTURA À ALTERNATIVA DOMINANTE: A MEdIAÇÃo dA PALAVRA}

Existem diversas discussões no âmbito da educação que problematizam a alternativa pedagógica dominante: a mediação da palavra. Esta é tida, ainda por muitos educadores, como a alternativa apropriada para a realização do ensino-aprendizado ou mesmo a força motriz da mediação do conhecimento. Assim sendo, esta ação contribui para o estabelecimento de práticas destrutivas ao real estimulo do 
conhecimento, pois o profissional docente ao desenvolver atividades que ignora a leitura de mundo o induzindo a roteiros determinados e pautados no desconhecido às realidades dos educandos apropria-se de conhecimentos sobre a leitura e a escrita e com base em sua compreensão consubstancia o que está operando de significados e representações, ou seja, estabelece uma relação de poder, pois "os usos sociais que são possíveis fazer de ambas e não somente incentivar os alunos a decodificar e codificar, valorizando o domínio da mecânica da leitura e da escrita, que em nada contribui para a constituição de um sujeito leitor e escritor" (CURY, 2008, p. 88), portanto, a cultura do visual deve estimular aos indivíduos olhares críticos e reflexivos.

A imagem visual se constitui por pinturas, gravuras, fotografias, filmes, impressos gráficos etc.) e deve ser potencial produtora de conhecimentos na Geografia, deve cumprir uma "função de eficiente artifício mnemônico no sentido da ligação com suas representações verbais gráficas, ainda mais quando estavam cultural e afetivamente associadas ao universo vivencial" (CARVALHO, 2004, p. 113). Conduzir as discussões na Geografia superando a mera superficialidade das objetivas e factuais análises das paisagens contribui para novos olhares metodológicos na educação geográfica, pois ultrapassar a condição imposta pelo que é visto, contribuindo para os sentidos e percepções estimula a produção do conhecimento científico, em especial para as mais diversas faixas etárias.

A ciência geográfica é essencial à compreensão das múltiplas dinâmicas socioespaciais que podem ser compreendidas a partir do que está posto na imagem visual e a partir disto produzir conhecimentos geográficos sobre processos que envolvem a (re)produção do espaço, as transformações das paisagens, as tensões geopolíticas, etc., para os mais diversos níveis de ensino. Diante do exposto, têm-se a existência de diversas discussões acadêmico-científicas que se debruçam em discutir a imagem visual como mediadora, ilustradora ou como recurso didático de conhecimentos. Entretanto, defende-se, portanto, a imagem visual como produtora de conhecimento na Geografia.

Nos sugere Carlos (2008, p. 15) "a invenção e o uso da imagem, como forma de representação do mundo visto e de mediação da sociabilidade humana", ou seja, é a partir desta velha/nova operacionalização no ensino-aprendizado que devemos 
estimular a educabilidade do olhar e sob estimulo à produção e análise da imagem visual contribuímos para uma educação visual validando assim a proposta freiriana alicerçada em uma educação consubstanciada na leitura de mundo tal como afirma Paulo Freire (1989, p. 9):

[...] A leitura do mundo precede a leitura da palavra, daí a posterior leitura desta não possa prescindir a leitura daquele. Leitura e realidade se prendem dinamicamente. A compreensão do texto a ser alcançada por sua leitura crítica implica a percepção das relações entre texto e contexto, [...].

Portanto, o uso da imagem visual pelo professor e seu estimulo devem se perpassar pelo envolvimento do cotidiano do estudante realizando-se para este entendimento um conhecimento prévio de seu público, seja por aplicação de questionário ou mesmo entrevista a partir de atividades ou no primeiro encontro em aulas para que possam desenvolver um trabalho direcionado e relacionado às realidades diversas dos estudantes para se sintam integrados ao processo histórico como sujeitos ativos no processo ensino-aprendizagem. Logo, utilizando-se este percurso metodológico para a educação visual se estabelecer motivam-se também as práticas de leitura e escritas, práticas imprescindíveis para a sua compreensão de mundo no presente ou no futuro.

O desenvolvimento e a realização de planejamento em Geografia para as turmas de qualquer nível e modalidade de ensino devem alicerçar-se na busca pela compreensão das dinâmicas sociais, espaciais e temporais em escalas local e global em uma perspectiva multidisciplinar. Também requer uma incorporação de conceitos/ conteúdos que vão além dos conceitos geográficos de paisagem, espaço e tempo, sociedade, lugar, região e território, pois requer uma prudência metodológica que abranja a diversidade dos temas transversais e que podem adotar uma proposta pedagógica freiriana baseada nos pilares ético (à visão do indivíduo como ser humano e ao processo de sua humanização), político (organização e gestão política do Estado e ao governo do indivíduo e da sociedade), epistemológico (situa e descreve o indivíduo como sujeito produtor de conhecimentos) contribuindo para a autonomia, a criticidade, o diálogo, a cultura, a libertação, o trabalho, a transformação, a práxis, a realidade, a subjetividade e o contexto superando assim a utilização da imagem 
como mero registro da realidade vivenciadas ou não pelos participantes do processo de ensino-aprendizado. No que se refere a educação geográfica a Lei de Diretrizes e Bases da Educação Nacional (LDB) n. 9.394/96:

[...] têm buscado práticas pedagógicas que permitam colocar aos alunos as diferentes situações de vivência com os lugares, de modo que possam construir compreensões novas e mais complexas a seu respeito. Espera-se que, dessa forma, eles desenvolvam a capacidade de identificar e refletir sobre diferentes aspectos da realidade, compreendendo a relação sociedade/natureza. Essas práticas envolvem procedimentos de problematização, observação, registro, descrição, documentação, representação e pesquisa dos fenômenos sociais, culturais ou naturais que compõem a paisagem e o espaço geográfico, na busca e formulação de hipóteses e explicações das relações, permanências e transformações que aí se encontram em interação. Nessa perspectiva procura-se sempre a valorização da experiência do aluno (BRASIL, 1996).

Observando-se o estabelecido pela LDB $\mathrm{N}^{\circ}$. 9.394/96 é possível relacionar questões do cotidiano que podem ser discutidos através dos diversos temas transversais e um dos mais abordados em Geografia é o Meio Ambiente e a ele atrela-se a possibilidade da confecção de cartões-postais, em oficinas, como estratégia de produção e mediação dos conhecimentos geográficos que podem contribuir para uma leitura crítica da realidade de uma comunidade.

Como sugestão temos a possibilidade de denunciar paisagens que requerem cuidados ambientais (poluição, por exemplo) estimulando a investigação e problematizando as possíveis causas de um fenômeno motivado por ação humana ou mesmo evidenciar casos de sucesso (recuperação de uma área degradada), ou mesmo problematizar diversos temas relacionados ao meio ambiente que podem se perpassar nas mais diferentes vertentes da educação ambiental permitindo através da imagem visual a possibilidade de inventariar não apenas imagens, mas produzir textos e reflexões estimulando-se assim a ativa ação cidadã contributiva a melhoria do espaço geográfico em que habita podendo oportunizar a socialização dos resultados da pesquisa na virtualidade em redes sociais ou blogs ou mesmo em exposição ou mural na escola, afinal, são muitas as possibilidades de comunicação e interação.

Recomenda-se, também, o uso da imagem visual como alicerce à prática didático-pedagógica em todas as aulas de Geografia, de modo parcial ou total, observando-se o conteúdo no itinerário formativo estimulando a aprendizagem tornando as 
aulas mais atrativas cabendo ao docente a análise prévia da mesma para que possa explorar e consubstanciar seu olhar e os olhares dos estudantes ao tema de discussão curricular na aula. Freire (1981, p. 35) afirma que "toda prática educativa envolve uma postura teórica por parte do educador", e assim sendo, a postura práxis docente enfatiza que o uso da imagem visual deve se perpassar pela leitura de mundo e mediada a uma teia de relações problematizadoras que busquem a libertação, ou seja, a elevação da consciência espacial cidadã, pois ainda de acordo com Freire (1981, p. 35) "esta orientação no mundo só pode ser realmente compreendida na unidade dialética entre subjetividade e objetividade. Assim entendida, a orientação no mundo põe a questão das finalidades da ação ao nível da percepção crítica da realidade". Por mais que a Geografia use a imagem visual, ainda não há reconhecimento de que a partir dela se pode produzir conhecimentos geográficos.

Um exemplo que nos convida à adoção e utilização da imagem visual em processos diversos de aprendizagem é o "reconhecimento do jogo da visualidade, de sua penetração na paisagem social e subjetividade" (CARLOS, 2008, p. 27) que mobiliza a leitura, a análise e a interpretação da imagem corroborando assim para validá-la para além de uma mera representação iconográfica do mundo, pois é por ela que circulam uma diversidade de mensagens consubstanciadas em "valores, concepções de mundo, ideologias, atitudes, comportamentos, saberes, preconceitos, produtos, desejos, sonhos e ilusões que são inseridos em nosso cotidiano e em nossa história sem percebermos" (CARLOS, 2008, p. 27). Portanto, ao utilizar-se da imagem para a alfabetização de uma palavra geradora (favela) podemos compreender diferentes dinâmicas socioespaciais, pois imbricada neste processo metodológico recomenda-se uma análise da

[...] situação existencial que representa em fotografia, aspecto de uma favela e em que se debate o problema da habitação, da alimentação, do vestuário, da saúde, da educação, numa favela e, mais ainda, em que se descobre a favela como situação problemática, se passa à visualização da palavra, com a sua vinculação semântica (FREIRE, 1967, p. 144).

Neste sentido, utilizando-se da imagem visual representada na materialidade de uma fotografia nos permite validar este procedimento ao valorizar-se na imagem visual fotográfica ou fílmica, por exemplo, "seus aspectos determinantes e em suas 
várias dimensões, que se vivencia empiricamente um primeiro nível de identificação com o lugar" (CAVALCANTI, 1998, p. 100). Faz-se necessário, portanto, ultrapassar a condição de que a imagem visual ainda é apenas uma mediadora ou ilustradora dos campos de domínio dos saberes geográficos, como suporte a compreensão das dinâmicas estudadas por disciplinas acadêmico-científicas associadas ao estudo geográfico como a Geomorfologia, a Geologia, a Hidrografia, a Educação Ambiental, entre outras.

No que diz respeito a educação e visualidade se faz necessária a compreensão da rede de significantes visuais e aqui enfatizamos que ela pode ser oriunda e contributiva à análise de um filme, uma fotografia, um desenho, pois para Carlos (2017, p. 558) "mobiliza, seleciona, articula e organiza na trajetória de sua produção visual: objetos, personagens, ações, ruídos, falas, diálogos, contrastes, cores, luminosidades, vestuários, duração, época, tempo, lugar, paisagem, situações e cenários." Estimular a cultura do uso da imagem visual e (re)pensarmos como ela é utilizada, seja como um clique para si, ou mesmo consumida pelas pessoas para os mais diversos fins se faz necessário.

As pessoas vivem fissuradas nas imagens, e elas circulam cotidianamente no espaço geográfico ou no ciberespaço podendo ter diversos usos. Ao defendermos o discurso sobre a imagem visual na Geografia para além das finalidades didático-pedagógicas afirmamos que por ela pode produzir conhecimentos geográficos, pois sua análise de modo aprofundado, a partir de diversos olhares, permite-nos uma série de compreensões sobre conceitos fundantes da Geografia superando-se a mera leitura das paisagens como um mero congelamento de um dado espaço-tempo elevando a perspectiva de Santos (2014, p. 67) que considera a paisagem como "tudo o que nós vemos, o que nossa visão alcança, é a paisagem. Esta pode ser definida como o domínio do visível, aquilo que a vista abarca. É formada não apenas de volumes, mas também de cores, movimentos, odores, sons etc.", ou seja, supera-se a condição tradicional da leitura de um conceito geográfico em que se considerava a paisagem como apenas o que se vê.

Afirma-se, portanto, a relevância da disseminação do conhecimento a partir do modo como a prática docente supera a mera condição bancária tal como afirma Frei- 
re (1967, p. 26), pois cabe ao professor-educador estar a serviço da libertação dos homens e mulheres alicerçado do objeto de estudo da ciência a qual estuda e leciona devendo este dirigir-se "às massas mais oprimidas, acreditou em sua liberdade, em seu poder de criação e de crítica" colocando a imagem como produtora de conhecimento e está tenderá a uma utilidade social contributiva ao entendimento do espaço geográfico ao qual os estudantes encontram-se inseridos, já que a imagem circula global e localmente através das redes sociais e de outros meios digitais. Então, diante disso, a nossa assertiva sobre a tese aqui empreendida é que a imagem visual é produtora de conhecimento geográfico.

\section{CONSIDERAÇÕES FINAIS}

A imagem visual também cumpre a função de modo interdisciplinar na produção do conhecimento na Geografia, pois os saberes estão sendo acionados nesses campos, dos mais diversos modos, como por exemplo, a análise da paisagem. Dito de outro modo, quando analisamos uma paisagem acionamos elementos de natureza econômica, social, política e cultural, isto é, a imagem visual fortalece múltiplos saberes elaborados que concernem a produção do conhecimento e ela precisa ser estimulada não apenas para sua leitura e interpretação, mas para que cada olhar de estudante possa ser revelado por suas próprias lentes e falas. Sendo assim, o atual status da imagem visual pode e deve ser superado na Geografia a partir de sua elaboração associada a produção de conhecimento geográfico.

Acreditamos, portanto, que os diversos processos de ensino-aprendizagem, relacionados ao uso da imagem visual, devem ser considerados, ou seja, fazem-se necessários para a realização de um plano de ação que considerem as dimensões sociais e intelectuais, pois é a partir destes processos que estabelecem-se o desenvolvimento pessoal dos participantes do processo de ensino-aprendizado, o desenvolvimento social dos sujeitos a partir do estímulo à participação, integração e sentimento de pertencimento à comunidade a partir do desenvolvimento de ações alicerçadas na consciência espacial-cidadã e que contribuem para o estabelecimento de uma sociedade justa. 
No que diz respeito ao desenvolvimento intelectual promovem-se atitudes responsáveis, a autonomia e a otimização das aprendizagens observando-se que as experiências universitárias também contribuem para a práxis social e podem ser oportunizadas através do uso da imagem visual. Já no desenvolvimento socioemocional estabelecem-se ferramentas e estratégias didático-pedagógicas que estimulam a melhora do relacionamento interpessoal entre todos os participantes garantindo-lhes profissionalismo e segurança emocional diante das dificuldades no exercício pessoal e profissional contribuindo para a educabilidade do olhar e a produção de conhecimentos geográficos por emergir uma melhor compreensão sobre as dinâmicas do espaço geográfico.

\section{REFERÊNCIAS}

BRASIL. Presidência da República. Lei de Diretrizes e Bases da Educação Nacional. Lei $\mathrm{n}^{\circ}$. 9.394/96 de 20 de dezembro de 1996. Estabelece as diretrizes e bases da educação nacional. Diário Oficial da União, Brasília-DF, ano 134, n. 248, p. 2783327841 , dez. 1996. Disponível em:<portal.mec.gov.br/seesp/arquivos/pdf/ lei9394_Idbn1.pdf>. Acesso em: 10 dez. 2020.

CARLOS, Erenildo João (Org.). Educação e visualidade: reflexões, estudos e experiências pedagógicas com a imagem. João Pessoa: Editora da UFPB, 2008.

CARLOS, Erenildo João (Org.). Educação e visualidade: a imagem como objeto do conhecimento. João Pessoa: Editora da UFPB, 2012.

CARLOS, Erenildo João. Sobre o uso pedagógico da imagem fílmica na escola. ETD-Educação Temática Digital Campinas, SP, v. 19, n. 2, p. 550-569, abr./jun. 2017. Disponível em: <https://periodicos.sbu.unicamp.br/ojs/index.php/etd/article/download/8645247/15712>. Acesso em: 20 fev. 2020.

CARLOS, Erenildo João; VICENTE, Dafiana do Socorro Soares (Orgs.). A importância do ato de ver. João Pessoa: Editora da UFPB, 2011.

CARVALHO, Vicente Vitoriano Marques. As imagens no "Método Paulo Freire" na experiência de Angicos (RN) 1963. In: Revista Educação em Questão, Natal, v. 21, n. 7, p. 98 115, set./dez. 2004.

CAVALCANTI, Lana de Souza. O ensino de geografia na escola. Campinas, SP: Papirus, 2012. 
CURY, Elenara Ues. O significado da mediação pedagógica no processo de alfabetização. InterMeio: revista do Programa de Pós-Graduação em Educação, Campo Grande, MS, v. 14, n. 27, p. 88-100, jan.-jun./2008. Disponível em: <https://periodicos.ufms.br/index.php/intm/article/view/2509/1717>. Acesso em: 10 jul. 2020.

FREIRE, Paulo. Educação como prática de liberdade: a sociedade brasileira em transição. Rio de Janeiro, Paz e Terra, 1967.

FREIRE, Paulo. A importância do ato de ler: em três artigos que se complementam. 22 ed. São Paulo: Cortez, 1989.

FREIRE, Paulo. Ação cultural para a liberdade: e outros escritos. 5 ed. Rio de Janeiro: Paz e terra, 1981.

GAUTHIER, Clermont. Por uma teoria da Pedagogia: Pesquisas contemporâneas sobre o saber docente. ljuí: Editora Unijuí, 1998.

PUNTEL, Geovane Aparecida. Os mistérios de ensinar e aprender Geografia. In.: REGO, Nelson; CASTROGIOVANNI, Antonio Carlos; KAERCHER, Nestor André. Geografia: práticas pedagógicas para o Ensino médio. Porto Alegre: Artmed, 2007, p. 89-102.

SANTOS, Milton de Almeida. Metamorfose do espaço habitado. 6 ed. São Paulo: EDUSP, 2014. 


\section{JOGOS DIDÁTICOS NO ENSINO}

\section{DE GEOGRAFL:}

\section{O TERRTÓÓRIO MUNDLAL EM DLSPUTA}

GABRIEL DE MIRANDA SOARES SILVA

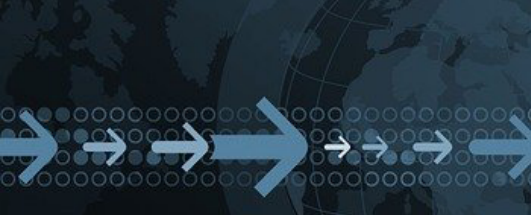
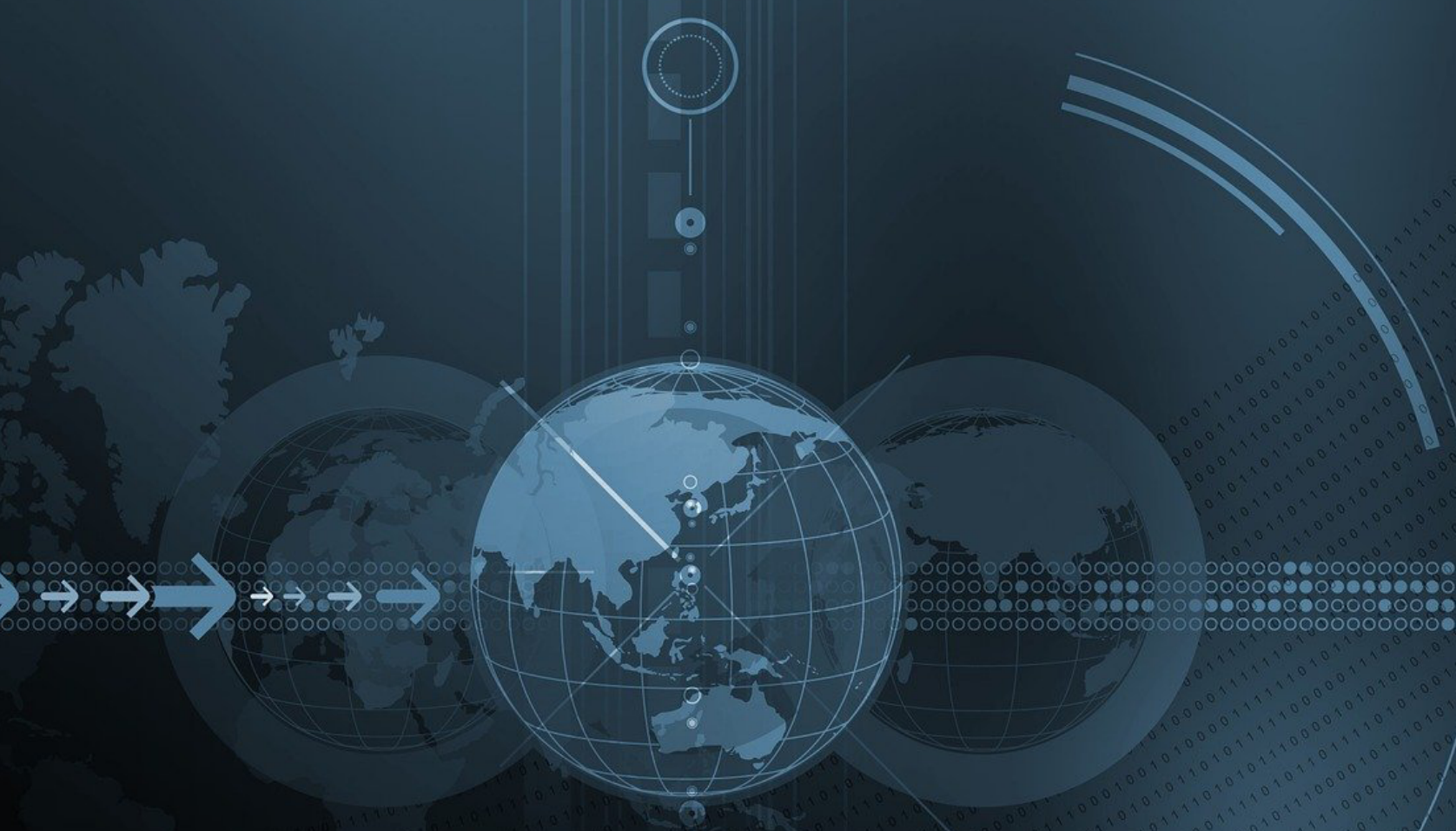

1 Discente de mestrado no Programa de Pós-graduação em Geografia da Universidade Federal do Mato Grosso (UFMT). E-mail: soares.ufmt@gmail.com 


\section{INTRODUÇÃO}

A contextualização dos diferentes espaços do globo é um dos compromissos da Geografia escolar e cabe ao professor de Geografia a missão de explorar os diferentes continentes junto aos alunos, demostras as paisagens, ultrapassas as formas de revelo e transpor os territórios. No entanto com o advento das mídias digitais aliado a tecnologia, cabe ao professor se reinventar, propondo novas formas de ensinar.

Sob este contexto apresentaremos nesta pesquisa alguns conceitos balizadores como o de território e fronteira, dando ênfase aos conflitos territoriais contemporâneos que acontecem nos diferentes continentes do globo. Assim propomos uma aproximação teórica e metodológica do conceito de território aliado as questões epistemológicas contemporâneas no ensino de Geografia.

Tendo como finalidade demostrar a relevância destes conteúdos no processo de construção geográfica ao longo do Ensino Fundamental e Médio, voltando os objetivos da Geografia que é de construir uma educação cidadã, onde os alunos apliquem os saberes e conceitos na vida cotidiana.

Por fim apresentamos duas propostas didáticas, que centram a atenção, sob a temática dos conflitos territoriais contemporâneos, com atenção a alguns conflitos que mais se destacam no cenário internacional. No primeiro momento pensamos em uma dinâmica em grupo onde o professor poderá trabalhar com a sala toda, e a mesma temática em formato de tabuleiro, onde o trabalho será individual.

\section{DESENVOLVIMENTO}

Cabe a Geografia a tarefa de apresentar aos alunos uma leitura de mundo sobre as óticas das categorias de análise da ciência geográfica, e é na escola que professores e alunos constroem estas relações (MOREIRA, 2008).

Neste sentido a construção do saber geográfico escolar se apresenta de suma importância já que a Geografia se revela como disciplina que possui significativa contribuição na formação de cidadãos, Cavalcante (1999, p. 74) ainda enfatiza que a presença da Geografia no currículo,

deve-se à necessidade que têm os alunos de aprender o espaço como dimensão da prática social cotidiana. [...] o espaço e as percepções e concepções sobre ele são construídas na prática social, de modo que vai se formando um 
conjunto de saberes sobre o espaço, mais ou menos sistematizados, científicos ou não. O conhecimento desse conjunto de saberes, a consciência do espaço, ou da "geografia" do mundo, pode ser construída no decurso da formação humana, incluindo aí a formação escolar. Por isso ela é estudada na escola.

O ensino de Geografia é pautando nos documentos norteadores da educação como a Lei de diretrizes e bases da Educação (LDB) de 1996 e Pelas Diretrizes Curriculares Nacionais Gerais da Educação (DCNs) de 2013, os Parâmetros Curriculares Nacionais (PCN) de 1998 e 2006, e a Base Nacional Comum Curricular (BNCC), assim todo o processo de ensino aprendizagem deve seguir as normativas além de federais, estaduais e municipais.

Assim é de suma importância que para além de compreender os temas e objetivos pautados nos documentos, se fazem necessário sob a elucidação dos termos utilizados pelos geógrafos para analisar o espaço geográfico, que de dentre estes documentos destacam: Espaço, Paisagem, Região, Território e Lugar (SILVA, 2019, grifos do autor). Entre as principais competências no ensino de Geografia estes documentos nos apresentam uma síntese dos objetivos da Geografia na educação básica, que é de

[...] localizar, compreender e atuar no mundo complexo, problematizar a realidade, formular proposições, reconhecer as dinâmicas existentes no espaço geográfico, pensar e atuar criticamente em sua realidade tendo em vista a sua transformação. (BRASIL, 2013, p. 43)

Ao pensar o território no âmbito escolar deve se levar em consideração as outras vertentes não a política, mais a econômica e cultural com pesos semelhantes. Na leitura de Sousa (2012), destaca que os geógrafos só remetem ao território sobre um viés da geografia política, ligado ao entendimento de nação na estrutura do Estado, e neste sentido cabe ao professor buscar outras primas, e não negligenciar outras vertentes do território aos alunos.

Neste contexto cabe ressaltar que o conceito de território é polissêmico e pode ser entendido por diferentes vertentes: Política, Econômica e Cultural como define Haesbaert (2004, 2016). A vertente política é privilegiada ao longo do processo de ensino-aprendizagem assim descaracterizando as outras vertentes desta categoria de análise. 
A leitura do conceito de território nos documentos oficiais, é pautada nos mesmos autores já supracitados anteriormente e remete a este conceito como:

relações de poder, por uma determinada área, além contextualizar o processo de territorialidade onde se entende os agentes sociais, políticos e econômicos, interferindo na gestão do espaço geográfico; não é apenas uma expressão cartográfica, assim refere-se aos projetos e práticas desses agentes, numa dimensão concreta, funcional, simbólica, afetiva, e manifesta-se em escala desde as mais simples às mais complexas. (BRASIL, 2000, p. 33)

Estes documentos se apresentam de forma generalizada ao pensar todo o território nacional não considerando as especificidades ao longo do processo de formação. Desta maneira cabe aos professores um redesenhar de suas práticas valorizando a influência linguística, cultural e social do espaço em que está inserida.

Neste sentido o conceito de território é bastante amplo e pode ser utilizado na leitura e interpretação de variados fenômenos geográficos. Assim Santos et al (2015) ao se apoiar na leitura de Crespo (2010) destaca que esta categoria de análise pode enfocar assuntos multidisciplinares como nas Ciências Sociais e Biologia.

Neste contexto Tavares e Bispo (2016), destaca que as diferentes abordagens, convém desenvolver uma compreensão sobre a dimensão territorial mais presente no contexto dos educandos. Assim "a construção dos conceitos ocorre pela prática diária, pela observação, pela experiência, pelo fazer” (CALLAI, 2003, p. 103).

Nesta pesquisa destacaremos os conteúdos referentes aos conflitos territoriais contemporâneos nos diferentes continentes do globo. Cabe ressaltar que os conflitos de se materializam sob o território, no entanto suas origens são variadas, e vão além de questões políticas, culturais e religiosas.

Ao que tangue os objetivos no processo de ensino-aprendizagem a BNCC, compartimenta estas em três fases: Unidades temáticas, Objetivos e Habilidades do conhecimento. A unidade temática onde as questões territoriais ganham destaque é a Conexões e escalas, onde é definida como unidade que detém a

a atenção está na articulação de diferentes espaços e escalas de análise, possibilitando que os alunos compreendam as relações existentes entre fatos nos níveis local e global. Portanto, no decorrer do Ensino Fundamental, os alunos precisam compreender as interações multiescalares existentes entre sua vida familiar, seus grupos e espaços de convivência e as interações espaciais mais complexas. A conexão é um princípio da Geografia que estimula a compreensão do que ocorre entre os componentes da sociedade e do meio físico natural. Ela também analisa o que ocorre entre quaisquer elementos 
que constituem um conjunto na superfície terrestre e que explicam um lugar na sua totalidade. Conexões e escalas explicam os arranjos das paisagens, a localização e a distribuição de diferentes fenômenos e objetos técnicos, por exemplo. (BRASIL, 2018, p. 362-363)

Levando em consideração a BNCC, destaco que durante o $8^{\circ}$ e $9^{\circ}$ ano do ensino fundamental, os alunos desenvolver as seguintes habilidades:

\section{Habilidades $8^{\circ}$ ano}

- (EF08GE05) Aplicar os conceitos de Estado, nação, território, governo e país para o entendimento de conflitos e tensões na contemporaneidade, com destaque para as situações geopolíticas na América e na África e suas múltiplas regionalizações a partir do pós-guerra.

- (EF08GE11) Analisar áreas de conflito e tensões nas regiões de fronteira do continente latino-americano e o papel de organismos internacionais e regionais de cooperação nesses cenários.

\section{Habilidades $9^{\circ}$ ano}

- (EF09GE08) Analisar transformações territoriais, considerando o movimento de fronteiras, tensões, conflitos e múltiplas regionalidades na Europa, na Ásia e na Oceania.

Já no Ensino Médio, a Geografia desaparece como componente curricular e passa a incorporar a área das Ciências Humanas e Sociais, assim como no ensino fundamental, cada área do conhecimento possui competências e habilidades a serem desenvolvidas ao longo do processo de ensino-aprendizagem. A competência 2 na área de Ciências Humanas traz como objetivo:

Analisar a formação de territórios e fronteiras em diferentes tempos e espaços, mediante a compreensão das relações de poder que determinam a territorialidades e o papel geopolítico dos Estados-nações. (BRASIL, 2018, p. 573)

Levando em consideração estas habilidades a serem desenvolvidas, apresentaremos uma proposta didática que leva em consideração a fixação dos conteúdos 
referentes aos conflitos territoriais contemporâneos, com destaque nos focos e tensões nos diferentes continentes do globo.

\section{RESULTADOS E DISCUSSÃO}

Apresentamos a proposta de uma gincana dentro da sala de aula. O objetivo deste jogo é de contextualizar e compreender a evolução dos fatos históricos e geográficos responsáveis pela fragmentação do território, ocorridos nos diferentes continentes do globo. Cabe também ressaltar que nas propostas, utilizaremos os princípios do raciocínio geográficos descritos na BNCC, e como exemplifica o quadro 1:

\section{Quadro 1: Descrição dos Princípios do Raciocínio Geográfico}

\begin{tabular}{|c|c|}
\hline Analogía & $\begin{array}{c}\text { Um fenômeno geográfico sempre é comparável a } \\
\text { outros. A identificação das semelhanças entre } \\
\text { fenômenos geográficos é o início da compreensão da } \\
\text { unidade terrestre. }\end{array}$ \\
\hline Conexão & $\begin{array}{c}\text { Um fenômeno geográfico nunca acontece } \\
\text { isoladamente, mas sempre em interação com outros } \\
\text { fenômenos próximos ou distantes }\end{array}$ \\
\hline Diferenciação & $\begin{array}{l}\text { É a variação dos fenômenos de interesse da } \\
\text { geografia pela superfície terrestre (por exemplo, } \\
\text { o clima), resultando na diferença entre áreas. }\end{array}$ \\
\hline Distribuição & Exprime como os objetos se repartem pelo espaço. \\
\hline Extensão & $\begin{array}{l}\text { Espaço finito e contínuo delimitado pela ocorrência } \\
\text { do fenômeno geográfico. }\end{array}$ \\
\hline Localização & $\begin{array}{l}\text { Posição particular de um objeto na superfície } \\
\text { terrestre. A localização pode ser absoluta (definida } \\
\text { por um sistema de coordenadas geográficas) ou } \\
\text { relativa (expressa por meio de relações espaciais } \\
\text { topológicas ou por interações espaciais). }\end{array}$ \\
\hline Ordem & $\begin{array}{l}\text { Ordem ou arranjo espacial é o princípio geográfico } \\
\text { de maior complexidade. Refere-se ao modo de } \\
\text { estruturação do espaço de acordo com as regras da } \\
\text { própria sociedade que o produziu. }\end{array}$ \\
\hline
\end{tabular}

Fonte: BRASIL, 2018, p. 361. 
Partindo destes princípios destaco os quatro continentes com focos de tensões mais notáveis no cenário mundial: Europa, Ásia, África e América, destacando os principais conflitos territoriais de cada contente. Na Europa destacamos a questão da imigração no mediterrâneo europeu², o movimento separatista na Espanha e a fragmentação da lugoslávia.

$\mathrm{Na}$ Ásia destacaremos o conflito Israel-Palestina no Oriente Médio, o conflito do Curdistão com países do Oriente Médio como Turquia, Irã e Síria, e por último a Caxemira, no Sul da China e Norte da Índia. Na América apresentamos o movimento de separação de Quebec no Canadá, o intenso fluxo de imigração nos Estados Unidos da América, e a questão do narcotráfico nos países Sul-americanos na rede de distribuição de entorpecentes em todo o globo.

No continente africano destacamos o conflito na região do Magreb no Norte africano conhecido também como África islâmica, onde as nações foram colônias das potencias europeias e ao longo do século XX foram se emancipando, a guerra civil no Sudão do Sul o mais novo país no mundo que sofre com guerras civis e economia fragilizada, e por último a questão agraria em Moçambique que passa a ser comparada com o estado de Mato Grosso no Brasil, onde empresários europeus e chineses passam a ocupar as terra moçambicanas para a produção de soja e algodão, com destino a exportação, principalmente para países europeus e para China³.

A dinâmica do jogo/ gincana será apresentada da seguinte maneira, primeiro a sala irá se dividir em quatro equipes com nomes dos respectivos continentes que serão abordados no jogo: América, África, Europa e Ásia. Posteriormente serão realizados embates previamente estruturados, onde cada equipe irá perguntar três vezes, como irá responder por três vezes, exemplo a equipe da América, irá fazer perguntas para as outras três equipes, como vai responder das outras três equipes. Assim a equipe que mais tiver assertos ganha a gincana.

2 Levamos em consideração os dados apresentados pela Organização Internacional das Migrações (OIM), divulgados entre 2015 e 2019. Na questão presente nas atividades do jogo deve-se levar em consideração o pedido de asilo formal feito aos países europeus pelos migrantes.

3 O programa Pró Savana se apresenta, como a parceria comercial entre o país da África Oriental Moçambique e empresários Mato-grossenses com capital estrangeiro oriundo de empresas europeias e chinesas. Esta parceria prevê a ocupação das terras moçambicanas, por um prazo de cem anos a estes empresários, que promoverão o cultivo de monoculturas de soja e algodão, com foco na exportação. 
Neste formato o professor deva dispor de um computador e um projetor para poder conduzir as atividades na sala de aula, já que ele devera projetar as questões para que as equipes possam visualizar e responder. Desta forma também toda a turma observara os assuntos a serem tratados e irão se apropriar do conhecimento dos diferentes conflitos já citados.

Cabe também a aplicação do jogo em formato de tabuleiro, que foi adaptado do jogo War®, onde os alunos poderão jogar com os mesmos conflitos já citados de maneira individual. Onde a cada aluno irá representar um continente (América, África, Ásia e Europa) e estará sob a posse das questões sobre o seu continente, a cada rodada ele irá desafiar outro aluno que representara outro continente.

Ao desafiar o outro continente o adversário deverá responder os questionamentos sobre os conflitos territoriais sendo que a cada resposta correta o adversário ganha um território do desafiador, e se caso a resposta for errada o adversário irá perder um território ao desafiador. Cada aluno (jogador) irá receber peões (cada território/ jogador de uma cor) que representara seus territórios conquistados no tabuleiro, como apresenta a figura 1.

Figura 1: Tabuleiro adaptado do Jogo Wor®

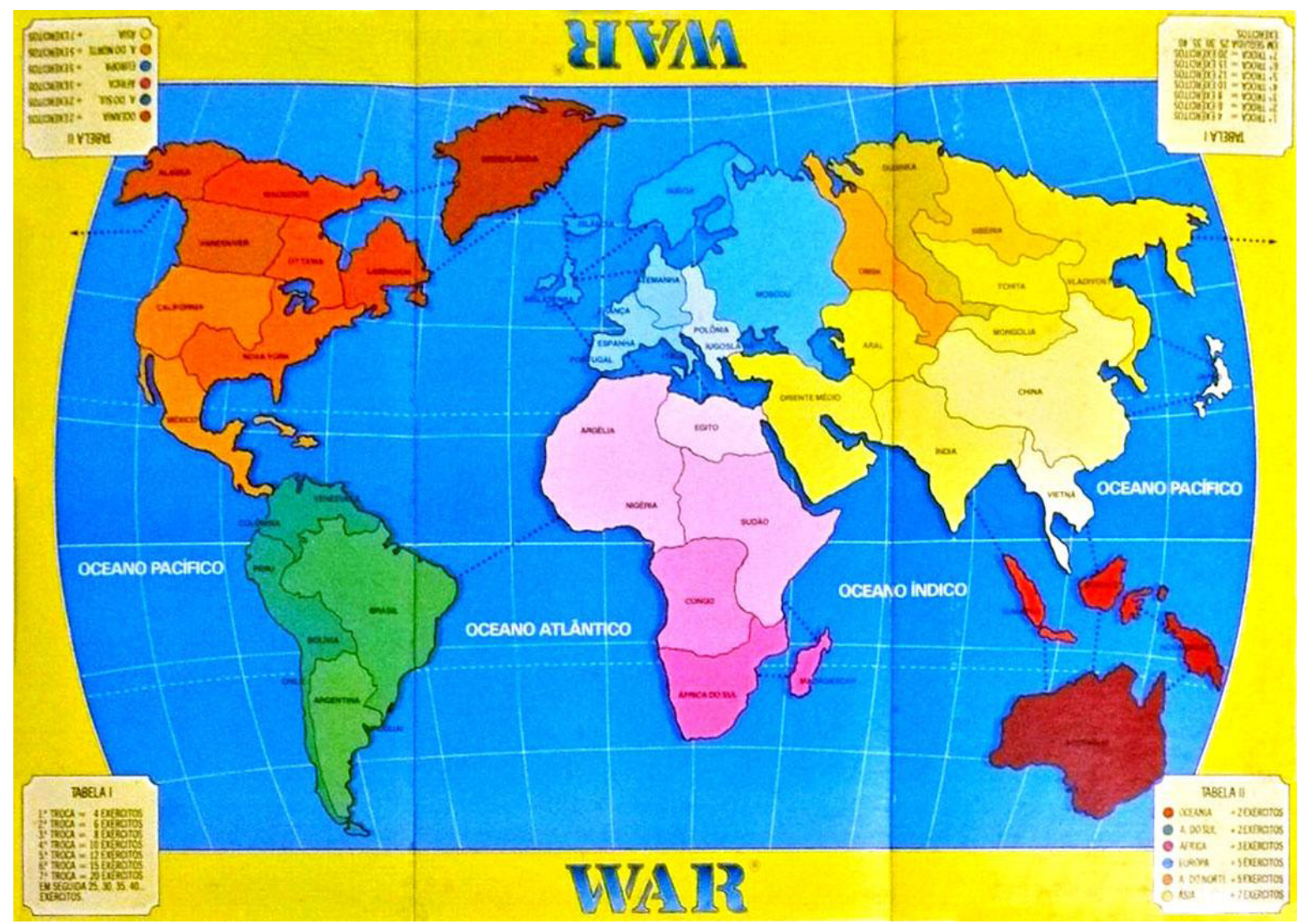

Fonte: Jogo Wor® 


\section{Cartas Auxiliares no Jogo}

\begin{tabular}{|c|c|c|}
\hline AMÉRICA 1 & AMÉRICA 2 & AMÉRICA 3 \\
\hline $\begin{array}{l}\text { No ano de } 2015 \text { o EUA pos- } \\
\text { suía cerca de } 47 \text { milhões de } \\
\text { imigrantes de várias } \\
\text { nacionalidades, chegando a } \\
\text { representar cerca de } 19,1 \% \\
\text { da população estadunidense. } \\
\text { Quais países são os } \\
\text { responsáveis pelas maiores } \\
\text { taxas de } \\
\text { imigração para os EUA? }\end{array}$ & $\begin{array}{l}\text { Quebec é uma província no } \\
\text { Leste canadense, que possui } \\
\text { divergências políticas e } \\
\text { socioculturais do restante do } \\
\text { país. O processo de } \\
\text { colonização que determinou o } \\
\text { idioma, a cultura e as } \\
\text { tradições. Qual país deu início } \\
\text { na colonização do Canadá e } \\
\text { deixou heranças socioculturais } \\
\text { na população de Quebec? } \\
\text { A) Inglaterra } \\
\text { B) França } \\
\text { C) Dinamarca } \\
\text { D) Holanda }\end{array}$ & $\begin{array}{l}\text { O narcotráfico age indiscrimi- } \\
\text { nadamente em todo o mundo. } \\
\text { Após a década de } 1990, \\
\text { formam uma rede de } \\
\text { produção e distribuição em } \\
\text { torno do globo. } \\
\text { Neste contexto qual país } \\
\text { iniciam operações militares } \\
\text { nos países amazônicos, sob o } \\
\text { pretexto de combater o } \\
\text { narcotráfico? }\end{array}$ \\
\hline $\begin{array}{c}\text { ÁFRICA } 1 \\
\text { Considerado o mais novo país } \\
\text { do mundo, se emancipando } \\
\text { no ano de 2011, possui como } \\
\text { a capital a cidade Juba. Com } \\
\text { uma guerra civil iniciada em } \\
\text { 2013, o país de 12,5 milhões } \\
\text { de habitantes tem uma das } \\
\text { piores situações humanitárias } \\
\text { do mundo. } \\
\text { Que país é este? }\end{array}$ & $\begin{array}{c}\text { ÁfFICA } 2 \\
\text { O Magreb é uma extensa } \\
\text { região situada no norte da } \\
\text { África, banhada pelo oceano } \\
\text { Atlântico e pelo mar } \\
\text { Mediterrâneo, e que apresenta } \\
\text { influência predominantemente } \\
\text { islâmica. Qual destes países } \\
\text { fazem parte do Magreb? }\end{array}$ & $\begin{array}{l}\text { ÁfRICA } 3 \\
\text { O movimento de ocupação } \\
\text { das terras agricultáveis de } \\
\text { Moçambique se assemelha } \\
\text { a ocupação das terras de que } \\
\quad \text { estado brasileiro? } \\
\text { A) Goiás } \\
\text { B) Mato Grosso } \\
\text { C) Tocantins } \\
\text { D) Piauí }\end{array}$ \\
\hline
\end{tabular}




\begin{tabular}{|c|c|c|}
\hline ÁSIA 1 & ÁSIA 2 & ÁSIA 3 \\
\hline $\begin{array}{l}\text { Qual o nome do conflito em } \\
\text { que Israel ocupa a Faixa de } \\
\text { Gaza, a Península do Sinai, } \\
\text { a Cisjordânia e as Colinas de } \\
\text { Golã, na Síria? } \\
\text { A) Guerra de Suez } \\
\text { B) Guerra dos Seis dias } \\
\text { C) Guerra da Península Sinai } \\
\text { D) Guerra da Faixa de Gaza }\end{array}$ & $\begin{array}{l}\text { Qual o nome da região histó- } \\
\text { rico-cultural do Médio Oriente } \\
\text { majoritariamente habitada } \\
\text { pelos curdos. Com cerca de } \\
500.000 \mathrm{~km}^{2} \text {, compreende } \\
\text { partes da Turquia, Irã, Síria e } \\
\text { Iraque? } \\
\text { A) Curdos } \\
\text { B) Curdistão } \\
\text { C) Sandjar } \\
\text { D) Sunitas }\end{array}$ & $\begin{array}{l}\text { Quais países estão envolvidos } \\
\text { no conflito da Caxemira? } \\
\text { A) China, Índia e Paquis- } \\
\text { tão. } \\
\text { B) China, Índia e Afeganistão. } \\
\text { C) Paquistão, Índia e Turcome- } \\
\text { nistão. } \\
\text { D) Paquistão, Tajiquistão e Tur- } \\
\text { comenistão. }\end{array}$ \\
\hline $\begin{array}{l}\text { Quantos países (Estados) } \\
\text { surgiram com a fragmentação } \\
\text { da lugoslávia? } \\
\text { A) } 5 \text { (Croácia, Eslovênia, } \\
\text { Macedônia, Montenegro e Sér- } \\
\text { via) } \\
\text { B) } 6 \text { (Bósnia- Herzecovê- } \\
\text { nia, Croácia, Eslovênia, } \\
\text { Macedônia, Montenegro } \\
\text { e Sérvia) } \\
\text { C) } 5 \text { (Bósnia- Herzecovênia, } \\
\text { Croácia, Eslovênia, Macedônia } \\
\text { e Montenegro) } \\
\text { D) } 6 \text { (Croácia, Eslovênia, Ma- } \\
\text { cedônia, Montenegro, Sérvia e } \\
\text { Albania) }\end{array}$ & $\begin{array}{l}\text { EUROPA } 2 \\
\text { Os países da UE podem acor- } \\
\text { dar vistos de residência a ci- } \\
\text { dadãos de países terceiros por } \\
\text { razões de emprego, educação } \\
\text { ou ainda em caso de } \\
\text { solicitação de asilo. } \\
\text { Qual a nacionalidades que } \\
\text { mais se refugiam na Europa? } \\
\text { A) Sírios e Eritreus } \\
\text { B) Senegaleses e Albaneses } \\
\text { C) Afegãos e Iraquianos } \\
\text { D) Malienses e Iraquianos }\end{array}$ & $\begin{array}{c}\text { EUROPA } 3 \\
\text { Movimentos Separatistas } \\
\text { acontecem em toda a Europa, } \\
\text { devido aos conflitos } \\
\text { sócioterritoriais que datam } \\
\text { dede-a idade média. Na } \\
\text { Espanha se destacam dois: } \\
\text { Catalunha e País Basco. } \\
\text { Qual importantes cidades se } \\
\text { encontram nestas províncias } \\
\text { espanholas? }\end{array}$ \\
\hline
\end{tabular}

Elaborado pelo autor, (2019).

Pensamos que estas dinâmicas podem favorecer o modelo de avaliação formativo, pautado em todo o processo de ensino-aprendizagem de Geografia. Neste sentido nós apoiamos na leitura de Castellar e Vilhena (2014, p. 45), onde destacam 
a importância de jogos e atividades lúdicas, que auxiliam não só processo de ensino aprendizagem, como nas percepções cognitivas, afetivas, psicomotoras e atitudinais, além de promover a integração das relações sociais adquiridas pelas observações da realidade e dos percursos percorridos no jogo. Já que Sacramento $(2017$, p. 225) evidencia que 0

Jogo é um pensamento é o resultado de um exercício reflexivo sobre algo concreto, no qual estão representes regras, condutas, valores, conceitos e identidades. [...] o jogo como atividade de ensino, que é de criar, executar, formas aos quais os estudantes consigam chegar ao resultado por meio de erros e acertos.

A autora ainda destaca que os jogos didáticos auxiliam a estimular a descrição, a análise, a associação e a criação de situações que proporcionam a compreensão de conceitos e dos conteúdos, desta forma auxiliando a aproximação dos conteúdos trabalhados no jogo, com as questões cotidianas.

\section{CONSIDERAÇÕES FINAIS}

Levando em consideração todo o arcabouço teórico e metodológico apresentado, destacamos que estes temas são pouco discutidos durante a formação do licenciado em Geografia, e são temas que são cobrados na sua jornada pedagógica nos anos finais do Ensino Fundamenta II e Ensino Médio.

Neste sentido cabe aos professores, além de um aprofundamento nos conceitos e conteúdos referentes a estas temáticas, buscar uma forma de apresentá-las com maior dinâmica aos alunos. Assim as propostas metodológicas de ensino aqui apresentadas se remetem a este propósito de aprimorar e dinamizar o processo de ensino-aprendizagem de Geografia no contexto escolar.

\section{REFERÊNCIAS}

5 fatos importantes sobre o conflito migratório entre EUA e México. Jornal Estadão [online]. São Paulo, Fev, 2017. Disponível: <https://internacional.estadao.com.br/ blogs/radar-global/5-fatos-importantes-sobre-o-conflito-migratorio-entre-eua-e-mexico/> Acesso em 16 de Jun. 2019.

A migração na Europa em números. Jornal Estado de Minas [online]. Minas Gerais, Mai, 2019. Disponível: <https://www.em.com.br/app/noticia/internacional/2019/05/20/ 
interna_internacional,1055100/a-migracao-na-europa-em-numeros.shtml> em 16 de Jun. 2019.

BRASIL. Parâmetros Curriculares Nacionais: Geografia/Secretaria de Educação Fundamental. Brasília: MEC/SEF, 1998.

BRASIL. Ministério da Educação. Base Nacional Comum Curricular. Versão homologada. Brasília: MEC, 2018. Acesso em: 13 de Abr. 2018.

CALLAI, Helena Copetti. Estudar o lugar para compreender o mundo. In: CASTROGIOVANNI, Antonio Carlos. Ensino de Geografia: práticas e contextualizações no cotidiano. 3.ed. Porto Alegre: Mediação, 2003. p. 83 -134.

CASTELAR, Sônia; VILHENA, Jerusa. (Orgs.). Ensino de geografia. São Paulo: Cengage Learing, 2014.

CASSANTA, Carlos José. Ético Sistema de Ensino: 6 ano ao 9 ano: Geografia: Ensino Fundamental: Livro do Professor. São Paulo: Saraiva, 2017.

CRESPO, M. P. Um estudo sobre o conceito de território na análise geográfica. III Encontro de Geografia - A Geografia e suas vertentes: reflexões. Rio de Janeiro, 2010. Anais... Rio de Janeiro, 2010.

CAVALCANTE, Lana de Souza. Propostas curriculares de Geografia no ensino: algumas referências de análise. Terra Livre, São Paulo, v. 14, p. 111-128, 1999.

HAESBAERT, Rogério. Descaminhos com o território. In: RIBAS, Alexandre Domingues; SPOSITO, Eliseu Savério; SAQUET. Marcos Aurélio. (Orgs.). Territórios e desenvolvimento: diferentes abordagens. Francisco Beltrão: Unioeste, 2004. p. 87120.

HAESBAERT, Rogério. Regional-Global: Dilemas da região e regionalização na geografia contemporânea. $2^{a}$ ed. Rio de Janeiro: Bertrand Brasil, 2014.

MELLO, Patrícia Campos. Moçambique oferece terra à soja brasileira. Jornal Folha de São Paulo [online]. São Paulo, Ago, 2011. Disponível em: < https://www1.folha. uol.com.br/fsp/mercado/me1408201102.htm > Acesso em 16 de Jun. 2019.

SACRAMENTO, Ana Claudia Ramos. A produção de jogos na formação docente: material didático ensino de geografia. In: PORTUGUAL, Jussara Fraga. (Org.). Educação Geográfica: temas contemporâneos. Salvador: EDUFBA, 2017. p. 221-233. 
fael Alonso Jeronimo; CUNHA, Rafael Denis Teixeira de. Território e geografia escolar: reflexões didáticas a partir da atuação de alunos bolsistas do PIBID. Enciclopédia Biosfera - Cetro Científico do Saber. Goiânia, 2012, v.11, n.22, p. 3434-3445.

SAMPAIO, Fernando dos Santos; SUCENA, Ivone Silvera (Orgs.). Geografia, $3^{\circ}$ ano: Ensino médio. São Paulo: Edições SM, 2010.

SILVA, Gabriel de Miranda Soares. Propostas metodológicas para o ensino de geografia urbana: um olhar geográfico sobre a cidade de Várzea Grande - MT. Cuiabá, 2019. Trabalho Final de Curso (Licenciatura em Geografia) - Universidade Federal de Mato Grosso.

SOUSA, Roberto Ribeiro de. O conceito de território no ensino de geografia: breves notas sobre abordagens negligenciadas. Geografia em questão. Cascavel, 2012, v. 05, n. 02, p. 149-165.

TAVARES, Silvaldo Quirino; BISPO, Marcileia Oliveira. Uma análise da abordagem territorial no ensino de geografia, na educação básica no centro de ensino médio Santa Rita de Cássia, Palmas, Sociedade e Território. Natal, 2016. Jan./Jun. v. 28, n. 1, p. 156-173. 


\section{INTRODUÇÃo}

A realização do Projeto de Ensino Geografia Agrária contextualizada em Canções oportunizou reflexões sobre o uso da música enquanto recurso didático para ensino da disciplina Geografia Agrária. Foi desenvolvido com o intuito de contribuir para um Ensino de Geografia mais lúdico, proporcionando aprendizagens significativas, apontando sobre a importância da linguagem musical, como recurso didático - metodológico também no Ensino Superior.

Na UERN, os Projeto de Ensino de Graduação (PEG) devem ser ofertados nos cursos de graduação da Universidade e são regulamentados pela Resolução № 33/2017 - CONSEPE.

De acordo com a referida Resolução, os objetivos do Projeto de Ensino de Graduação na UERN são os seguintes:

Art. $2^{\circ}$ São objetivos do Projeto de Ensino de Graduação - PEG:

I. Promover o processo de inovação da prática pedagógica nos cursos de graduação;

II. Desenvolver a reflexão crítica pertinente às questões de ensino - aprendizagem, indicando meios para sua reformulação e desenvolvimento nos cursos de graduação;

III. Produzir material de cunho didático-pedagógico de apoio aos componentes curriculares dos cursos de graduação;

IV. Auxiliar a formação acadêmica dos discentes, complementando o conteúdo programático dos componentes curriculares dos cursos de graduação;

V. Propor ações inovadoras que elevem a qualidade de ensino de graduação.

Para efetivação do referido projeto, foi feito a princípio, um levantamento bibliográfico, para compor o referencial teórico, sobre o uso de diferentes linguagens no Ensino de Geografia, com ênfase na utilização da música como recurso didático - metodológico importante.

Cada participante do Projeto, pesquisou músicas relacionadas a temática de Geografia Agrária, organizando-as de acordo com temáticas, para que possam ser utilizadas como subsídio didático durante as aulas de Geografia Agrária, a partir da elaboração de sequências didáticas (sd), que auxiliaram no processo de ensino aprendizagem. 
Foram pesquisadas músicas de diferentes gêneros musicais, sobre temáticas associadas a Geografia Agrária como: migração rural urbana e êxodo rural, reforma agrária, assentamento, pobreza e cidadania por exemplo. As músicas foram selecionadas previamente, de acordo com o conteúdo ministrado na disciplina. Ao ministrar conteúdos sobre reforma agrária por exemplo, trabalhamos com os conceitos de acampamento e assentamento, e para introdução da temática podemos utilizar as músicas Assentamento e Funeral de um Lavrador, como possiblidade metodológica para discussão.

Assim sendo, consideramos que a realização desse Projeto de Ensino, contribuiu para o aprofundamento teórico-metodológico da disciplina Geografia Agrária e consolidação do processo de ensino-aprendizagem dos discentes.

\section{A IMPORTÂNCIA de MEtOdOlOgIAS ATIVAS NA APRENDIZAGEM GEOGRÁFICA}

O célebre geógrafo francês Yves Lacoste, escreveu em meados da década de 1970 o célebre livro A Geografia, isso serve em primeiro lugar, para fazer a guerra. No livro o autor critica a dualidade existente na Geografia, entre a chamada "Geografia dos Estados Maiores" e a chamada "Geografia dos Professores".

De acordo com o autor, a Geografia do mundo marcada pela Guerra Fria, primeiro atendia aos interesses geopolíticos dos "Estados Maiores", e não priorizava a "Geografia dos Professores", ou seja, nas Escolas eram trabalhados conteúdos descontextualizados da realidade da sociedade, priorizando a descrição e memorização.

Aquele autor questionava os conteúdos e métodos tradicionais de ensino adotados na Geografia, que não priorizavam o entendimento da complexidade dos fenômenos geográficos. Dessa forma, fazendo com que a Geografia nas Escolas se transformasse numa disciplina "simplória e enfadonha". Então nos perguntamos sobre quais metodologias podem potencializar o processo de ensino-aprendizagem dessa disciplina?

As críticas de Yves Lacoste apontam para a necessidade de (re) visitar nossas práticas metodológicas em sala de aula, de forma a contribuir com o processo do ensino-aprendizagem dos alunos, tanto no Ensino Superior como no Ensino Básico. Nos PCNs encontramos críticas a esse modelo de ensino, descrito anteriormente 
pelo referido autor:

No ensino, essa Geografia se traduziu (e muitas vezes ainda se traduz) pelo estudo descritivo das paisagens naturais e humanizadas, de forma dissociada dos sentimentos dos homens pelo espaço. Os procedimentos didáticos adotados promoviam principalmente a descrição e a memorização dos elementos que compõem as paisagens como dimensão observável do território e do lugar. Os alunos eram orientados a descrever, relacionar os fatos naturais e sociais, fazer analogias entre eles e elaborar suas generalizações ou sínteses. Explicá-las sim, porém evitando qualquer forma de compreensão ou subjetividade que confundisse o observador com o objeto de análise. Pretendia-se ensinar uma Geografia neutra. Essa perspectiva marcou também a produção dos livros didáticos até meados da década de 70 e muitos ainda apresentam em seu corpo idéias, interpretações ou até mesmo expectativas de aprendizagem defendidas pela Geografia Tradicional. (BRASIL, 1998, p. 21)

Com o passar do tempo a Geografia foi incorporando conteúdos mais significativos para formação do cidadão, com um olhar mais crítico para realidade que se vivencia. Devemos buscar superar, aquela Geografia "simplória e enfadonha", entendendo que o ensino de Geografia não pode estar desconectado da realidade em que o aluno está inserido, buscando alcançar um processo de ensino-aprendizagem significativo, com a utilização de diferentes metodologias e linguagens que contribuam para superação desse tipo de ensino pouco reflexivo.

Como vimos, uso de diferentes linguagens no ensino de Geografia está presente em documentos oficiais como os PCN's, desde o Ensino Fundamental, despertando no professor a necessidade constante de repensar sua prática, no intuito de fortalecer o processo de ensino-aprendizagem. Uma dessas linguagens é a música, que além de elemento cultural e de lazer, pode ser utilizada como recurso metodológico, durante a explicação de conteúdo em várias áreas de conhecimento.

A música tem acompanhado a humanidade em diferentes tempos e espaços, está presente em todas as culturas, e com isso podemos dizer que a música pode ser considerada uma linguagem universal. A linguagem musical está presente no nosso dia a dia em seus mais diferentes estilos musicais, exercendo as mais diferentes funções culturais e de lazer.

Mas acreditamos que, para além de uma manifestação cultural, a música também pode ser considerada como um importante recurso metodológico no ensino de Geografia, tendo em vista que o momento atual nos convida a refletir sobre a utili- 
zação de metodologias ativas no ensino, tanto no Ensino Básico como no Ensino Superior.

Segundo Castellar (2016), a concepção principal das metodologias ativas seria: (...) "colocar o aluno em estado de mobilização, utilizando recursos e abordagens adequados para os alunos e para os conteúdos e objetivos definidos" (CASTELLAR, 2016, p.42).

A autora acrescenta que o professor deve ser visto como um mediador nesse processo, buscando metodologias que despertem o interesse do aluno. "Sendo o aluno o protagonista e grande participante do processo de ensino -aprendizagem, cabe ao professor ser o mediador, facilitando o acesso ao conhecimento" (CASTELLAR, 2016, p.10).

"Um aluno estimulado busca sentido no que aprende; se desestimulado, não encontrando sentido naquilo que está estudando, reforça os obstáculos que podem dificultar a aprendizagem" (CASTELLAR, 2016, p.9).

Tomamos de empréstimo as afirmações de Freire (1996) quando afirmar que, "não basta dominar os conteúdos, o professor deve refletir constantemente sobre sua prática". Com isso, os cursos de licenciatura, devem ter a preocupação constante com metodologias de ensino que ensino e pesquisa caminhem juntos.

Não há ensino sem pesquisa e pesquisa sem ensino. Esses que-fazeres se encontram um no corpo do outro. Enquanto ensino continuo buscando, reprocurando. Ensino porque busco, porque indaguei, porque indago e me indago. Pesquiso para constatar, constatando, intervenho, intervindo, educo e me educo. Pesquiso para conhecer e o que ainda não conheço e comunicar ou anunciar a novidade. (FREIRE, 1996, p.16)

"Um processo de aprendizagem orientado e mediado pelo professor permite a todos os envolvidos superar obstáculos e dificuldades. Ações pedagógicas adequadas e alinhadas a fundamentos teóricos da disciplina enriquecem o trabalho em sala de aula" (CASTELLAR, 2016, p.12). Sendo assim, a aprendizagem numa perspectiva ativa, é entendida como:

A aprendizagem ativa engloba experiência concreta (um evento) e experimentação ativa (planejamento de uma experiência). Ao mesmo tempo exige reflexão, observação (pensar sobre o que ocorreu) e abstração de um conceito (pensar sobre o que aprendeu e estabelecer relação com o que já foi aprendido). A aprendizagem, em uma perspectiva da metodologia ativa, é vis- 
ta como um gradual, mas cumulativo desenvolvimento de saberes por meio da participação em atividades nas quais o conhecimento é progressivamente construído, aplicado e revisto. (CASTELLAR, 2016, p.71)

Uma das maneiras de trabalhar com metodologias ativas é utilizando a música como recurso didático-metodológico nas aulas de Geografia. Isso porque o uso da música contribui para o aluno perceber que a geografia faz parte do seu cotidiano, é muito mais de que um conteúdo para estudar para fazer uma prova.

"Se nossos alunos puderem ter na Geografia um instrumento útil de leitura do mundo, estaremos ajudando a construir não só uma escola como uma sociedade mais crítica e indignada contra toda e qualquer miséria humana" (KAERCHER, 1996, p.113).

O que há de geográfico nas letras de algumas músicas? Será que a música deve ser vista como uma ferramenta metodológica importante no ensino de Geografia?

Kaercher (1996), vai propor a realização de atividades com música, no artigo a geografia é nosso dia-a-dia:

Meu objetivo aqui, não é propor simplesmente trabalhar com música em sala de aula. É chamar a atenção que as músicas ouvidas cotidianamente por nós e nossos alunos trazem a questão social/espacial em suas letras e que podemos começar alguns assuntos novos com este "chamariz". Desperta mais a atenção do que iniciarmos nossa aula, ainda que bem intencionada e de cunho progressista, com aulas expositivas abstratas e distantes do mundo do aluno. A música não substitui a problematização/reflexão/sistematização do professor. Só a inicia. A nossa relação com o aluno continuará sendo sempre o centro do processo pedagógico. O objetivo maior não é (só) tomar a aula mais "legal" (será que esse é um objetivo a ser perseguido por nós professores?) mas sim. a partir das letras. questionar o que o aluno já sabe a fim de superar visões de mundo conformistas conservadoras ou ligadas somente ao senso comum. Que grupos, cantores mais poderemos usar em nossas aulas? Lembrei-me do Legião Urbana, do Gabriel Pensador, dos Titãs .... Mas são tantos outros! (KAERCHER, 1996, p.115)

A citação acima reforça a necessidade de utilizar a música, como forma de tonar a aula de Geografia mais atrativa, colocando o aluno no centro do processo de ensino-aprendizagem. Além dessas músicas citadas pelo autor, encontramos diversas músicas nacionais que retratam aspectos de problemas brasileiros. 


\section{A UTILIZAÇÃo dA LINGUAGEM MUSICAL NAS AULAS dE GEOGRAFIA AGRÁRIA}

Na matriz curricular do Curso de Geografia da FAFIC/UERN, modalidade Licenciatura, a disciplina Geografia Agrária é ofertada regularmente no $4^{\circ}$ período do Curso. De acordo com matriz curricular do Projeto Pedagógico do Curso (PPC) de Geografia da UERN, a ementa da disciplina Geografia Agrária é a seguinte:

A Geografia Agrária no contexto da Geografia Humana. Questão agrária e questão agrícola. Elementos da organização do espaço agrário. A atividade agropecuária no espaço produtivo mundial. Formação da estrutura fundiária brasileira. Modernização da agricultura. Reforma agrária, relações de trabaIho e movimentos sociais no campo. O agronegócio e a pequena produção camponesa. O campesinato e a agricultura familiar. A questão agrária e o meio ambiente. (UERN, PPC, 2018)

A ementa da disciplina revela uma preocupação com conteúdos relacionados as transformações ocorridas no campo brasileiro, marcado por grande complexidade, necessitando de análises contextualizadas a fatos históricos para melhor compreender a realidade, que perpassa desde o processo de colonização de exploração do território, expropriando a terra dos indígenas.

O acesso à terra no Brasil sempre foi um privilégio da população mais rica, em detrimento da população mais pobre, desde a época das Capitanias Hereditárias, passando pelas Sesmarias e Lei de Terras. Ao longo do tempo, esse processo excludente motivou o surgimento de revoltas populares e movimentos sociais que lutavam pela terra.

Mas foi em meados do século XX, que os trabalhadores camponeses se organizaram de forma mais efetiva em Associações e Sindicatos, e fundaram o movimento que ficou conhecido como Ligas Camponesas. A princípio, as Ligas Camponeses lutavam contra a exploração dos latifundiários da cana-de-açúcar no Pernambuco, mas posteriormente ampliaram sua luta pelos direitos dos trabalhadores rurais em vários estados nordestinos, colocando a necessidade de tornar pública o debate sobre a reforma agrária. Mas com a chegada dos militares no poder, em meados da década de 1960, as Ligas Camponesas foram extremamente reprimidas.

$\mathrm{Na}$ década de 1980 vai surgir o Movimento dos Trabalhadores Rurais Sem Terra (MST), que pressiona o Estado, a nível nacional, chamando atenção para o 
debate e necessidade de implantação da reforma agrária, mediante a formação dos assentamentos rurais.

Esses são apenas, alguns dos elementos constituintes da complexa questão agrária nacional, presentes na disciplina Geografia Agrária, que tem o propósito de despertar no discente da graduação em Geografia, uma visão crítica das contradições existentes no campo brasileiro, marcada pela desigualdade de acesso à terra, privilegiando o latifúndio e a monocultura.

A questão agrária brasileira, está atrelada a formação territorial do país, marcada pela exclusão de uma camada da população, que posteriormente se organizaram e lutaram contra a expropriação e violência, dando origem a diversos movimentos sociais de luta pela terra.

Algumas dessas lutas, que reforçam elementos da questão agrária contidos na formação territorial do Brasil, podem ser visualizadas na música Revolta Olodum, composta por José Olissan e Domingos Sérgio.

Retirante ruralista, lavrador Nordestino lampião, salvador Pátria sertaneja, independente Antônio conselheiro em canudos presidente

Zumbi em Alagoas, comandou Exercito de ideais Libertador, eu Sou majin kabalaiada

Sou malê

Sou búzios sou revoltas, arerê

Oh corisco, maria bonita mandou te chamar Oh corisco, maria bonita mandou te chamar

É o vingador de lampião

É o vingador de lampião

Êta cabra da peste

Pelourinho, Olodum somos do nordeste Êta cabra da peste

Pelourinho, Olodum somos do nordeste Êta cabra da peste

Pelourinho, Olodum somos do nordeste Êta cabra da peste

Pelourinho, Olodum somos do nordeste

Oh Corisco, Maria bonita mandou te chamar Oh Corisco, Maria bonita mandou te chamar 
Como podemos perceber nesta música, os elementos geográficos são diversos, fazendo referência a diversos movimentos sociais ocorridos no Nordeste como Canudos e o Cangaço, além de evocar diferentes personagens relacionados ao campo como retirante, ruralista e lavrador.

Ainda no tocante ao contexto educativo da disciplina Geografia Agrária, podemos citar como exemplo, a música Funeral de um lavrador, do compositor Chico Buarque de Holanda. Vejamos sua letra:

Esta cova em que estás, com palmos medida

É a conta menor que tiraste em vida

É de bom tamanho, nem largo, nem fundo

É a parte que te cabe deste latifúndio

Não é cova grande, é cova medida

É a terra que querias ver dividida

É uma cova grande pra teu pouco defunto Mas estarás mais ancho que estavas no mundo

É uma cova grande pra teu defunto parco Porém mais que no mundo, te sentirás largo

É uma cova grande pra tua carne pouca

Mas à terra dada nao se abre a boca

É a conta menor que tiraste em vida

É a parte que te cabe deste latifúndio

(É a terra que querias ver dividida)

Estarás mais ancho que estavas no mundo

Mas à terra dada não se abre a boca

Na música Funeral de um lavrador encontramos o termo latifúndio explícito em sua letra, além de elementos que reforçam a urgência da reforma agrária no Brasil, com trabalhadores rurais sem-terra, que trabalharam a vida inteira em terras de patrões, mas que nunca saíram da pobreza e da miséria.

Outro exemplo de canção com temática encontrada na Geografia Agrária, podemos citar a música Assentamento, do compositor Chico Buarque de Holanda. Vejamos sua letra:

\section{6}


Crescido de coração

Zanza daqui, zanza pra acolá

Fim de feira, periferia afora A cidade não mora mais em mim Francisco, Serafim Vamos embora Embora

Ver o capim Ver o baobá

Vamos ver a campina quando flora

A piracema, rios contravim Binho, Bel, Bia, Quim Vamos embora

Quando eu morrer Cansado de guerra Morro de bem

Com a minha terra: Cana, caqui Inhame, abóbora Onde só vento se semeava outrora Amplidão, nação, sertão sem fim Oh, Manuel, Migüilim Vamos embora

Amplidão, nação, sertão sem fim Oh, Manuel, Migüilim Vamos embora

Quando eu morrer Que me enterrem na beira do chapadão

Contente com minha terra Cansado de tanta guerra Crescido de coração

Na música Assentamento o compositor reforça aspectos do conceito de lugar e de identidade rural. Reforça aspectos do êxodo rural forçado, porque muitas pessoas saem do campo, em busca de melhores condições de vida nas cidades, e nem sempre encontram, muitos vão viver de subempregos nas áreas periféricas.

Vários conceitos de Geografia Agrária, podem ser explicados com o apoio da linguagem musical, para ratificar o seu entendimento, vejamos a letra da música Admirável Gado Novo, do compositor Zé Ramalho: 
Ôoo... Hei boi

Vocês que fazem parte dessa massa Que passa nos projetos do futuro

É duro tanto ter que caminhar

$E$ dar muito mais do que receber

$E$ ter que demonstrar sua coragem À margem do que possa parecer $E$ ver que toda essa engrenagem Já sente a ferrugem lhe comer

Êh, ô, ô, vida de gado Povo marcado Êh, povo feliz!

Lá fora faz um tempo confortável

A vigilância cuida do normal Os automóveis ouvem a notícia Os homens a publicam no jornal

E correm através da madrugada

A única velhice que chegou Demoram-se na beira da estrada E passam a contar o que sobrou!

Êh, ô, ô, vida de gado Povo marcado Êh, povo feliz!

O povo foge da ignorância Apesar de viver tão perto dela E sonham com melhores tempos idos

Contemplam esta vida numa cela

Esperam nova possibilidade De verem esse mundo se acabar

A arca de Noé, o dirigível Não voam, nem se pode flutuar

Êh, ô, ô, vida de gado

Povo marcado Êh, povo feliz!

Essa música retrata a realidade encontrada por muitos trabalhadores sem-terra que lutam pela terra e pela reforma agrária, "pois é duro tanto ter que caminhar", em manifestações que almejam esse direito. A maioria dos acampamentos são organizados nas cidades, as margens das rodovias "que demoram-se na beira da estrada".

Como vimos nesses exemplos anteriores, as possibilidades de trabalhar com música no ensino da disciplina Geografia Agrária são inúmeras. Pois as músicas, 
carregam grandes significados que, dependendo do conteúdo ministrado, servem como alternativa didática para auxiliar o trabalho do professor na explicação dos conteúdos, de forma mais próxima a realidade do aluno.

\section{CONCLUSÃO}

Acreditamos que o desenvolvimento do Projeto de Ensino Geografia Agrária contextualizada em Canções, na disciplina Geografia Agrária, contribuiu para o aprofundamento teórico-metodológico da referida disciplina através do processo de ensino-aprendizagem dos discentes, desenvolvido de forma mais lúdica com a linguagem musical.

Como vimos, em Geografia Agrária podemos explorar diversas temáticas relacionadas ao campo brasileiro, desenvolvendo um trabalho de forma interdisciplinar, articulada com outras temáticas da Geografia como cidade, juventude, racismo, violência, meio ambiente etc.

Despertando assim, reflexões importantes nos estudantes de graduação e nos professores, sobre a importância de refletir sobre a sua didática em sala de aula, utilizando metodologias diferenciadas para potencializar o processo de ensino - aprendizagem, contribuindo assim, para um ensino de graduação cada vez mais articulado com a realidade em que está inserido.

Consideramos oportuna a realização desse Projeto de Ensino, contribuindo com reflexões para o ensino de graduação na disciplina Geografia Agrária, apontando a importância do uso de músicas no Ensino de Geografia no Ensino Superior, contribuindo para aproximar o conhecimento geográfico ao cotidiano dos indivíduos.

\section{REFERÊNCIAS}

BRASIL. Secretaria de Educação Fundamental. Parâmetros Curriculares Nacionais: Geografia. Brasília: MEC/ SEF, 1998.

CASTELLAR, Sonia M. Vanzella (Org.). Metodologias Ativas: Introdução. São Paulo: FTD, 2016.

. Metodologias Ativas: Sequências Didáticas. São Paulo: FTD, 2016.

FREIRE, Paulo. Pedagogia da Autonomia: saberes necessários à prática educa- 
tiva. São Paulo: Paz e Terra, 1996

KAERCHER, Nestor André. A Geografia é nosso dia-a-dia. Boletim Gaúcho de Geografia. Porto Alegre: AGB, 1996. 109 -116pp

LACOSTE, Yves. A Geografia - isso serve, em primeiro lugar, para fazer a guerra. 3.ed. Campinas: Papirus, 1988.

UERN. Departamento de Geografia. Projeto Pedagógico do Curso (PPC). Mossoró: CONSEPE, 2018.

UERN. Conselho de Ensino, Pesquisa e Extensão. RESOLUÇÃO N 33/2017 - CONSEPE. Regulamenta o Projeto de Ensino de Graduação nos cursos de graduação da Universidade do Estado do Rio Grande do Norte. Mossoró: UERN/CONSEPE, 2017.

Buarque, Chico. Assentamento. In: Terra. São Paulo: Companhia das Letras, 1997. . Funeral de um Lavrador. In: Chico Buarque de Holanda - Volume 3. Rio de Janeiro: Som Livre. 1968.

OLISSAN, José e SÉRGIO, Domingos. Revolta Olodum. In: LP Comprometida. Rio de Janeiro: Copacabana. 1992.

Ramalho, Zé. Admirável Gado Novo. In: Zé Ramalho 2. Rio de Janeiro: Epic, 1979. 


\section{LUZ, CAMERA, AÇÃO:}

\section{A PRODUÇO AUDIOVISUAL COM TECNOLOGIAS DIGITAIS DE}

\section{INFORMAÇÃO E COMUNICAÇÃO (TDICs)} COMO METODOLOGIA ATIVANA EDUCAÇÃO GEOGRÁFICA

LUIZ DE VASCONCELLOS FERREIRA SOBRINHO

ROSEMY DA SILVA NASGIMENTO

1 Graduado e licenciado em Geografia (PUC-SP - 1988), Mestre em Geografia (UFSC - 2012) e doutorando em Geografia (UESC). Professor efetivo da Prefeitura Municipal de Florianópolis desde 1998. Coordenador do Núcleo de Cinema.MTC na E. B. Maria Tomázia Coelho em Florianópolis desde 2013. E-mail para contato luiz.ferreira@prof.pmf.sc.gov.br

2 Prof Dr $^{\mathrm{a}}$ Rosemy da Silva Náścimento é docente Titular do Departamento de Geociências (CFH/UFSC), atua nos Cursos de Graduação em Geografia, da Licenciatura Intercultural Indígena

$\Leftrightarrow$ do Sul da Mata Atiântica - Guarani, Kaingang e Laklânō-Xokleng, cursos de mestrado e doutorado do Programa de Pós-Graduação em Geografia da UFSC. assim como na pesquisa, extensão, publicação, orientação e formação continuada de professores(as) nas temáticas da Educação Geográfica, Cartografia Escolar/Tátil e Educação Ambiental. É coordenadora do Laboratório de Cartografia Tátil e Escolar (LabTATE) e membro dos Grupos de Pesquisa: Ensino de Geografia, Formação Docente e Diferentes Linguagens; Núcleo de Estudos e Pesquisas em Ensino de Geografia (NEPEGeo) e Resolução Científica de Conflitos. Diretora de Produção e Divulgação Científica do Instituto LARUS - Pesquisa, Proteção e Educação Ambiental. E-mail para contato: rosemy.nascimento@ gmail.com 
Tão importante quanto aprender a ler, é aprender a ver.

Luis Campos Martinez

\section{INTRODUÇÃO}

A intensa aceleração do ritmo das transformações tecnológicas e o controle sobre as informações e seus fluxos têm sido hegemonicamente utilizados para o exercício do poder e ampliação das desigualdades territoriais, econômicas, políticas, sociais e informacionais influenciando a maneira como as pessoas pensam e agem. No entanto, ao mesmo tempo em que podem proporcionar ameaças de homogeneização cultural, essas mesmas ferramentas podem oferecer oportunidades de diversificação e pluralismo sociocultural. Se por um lado, muitas histórias podem ser ocultadas em função de constrangimentos políticos e econômicos, por outro, elas podem ser reveladas por organizações independentes (WILSON, 2013).

No Brasil, apesar de ainda existirem muitos obstáculos socioeconômicos e regionais, cresce a proporção de crianças e jovens com acesso à Internet e posse de smartphones (IBGE, 2020). Contudo, o fato de estarem familiarizados com esses recursos não significa, necessariamente, que sejam capazes de levar em conta todas as dimensões deste uso. Se por um lado observa-se que crianças e adolescentes possuem algumas habilidades no uso de dispositivos digitais móveis, por outro falta-Ihes maturidade para reconhecer alguns dos riscos aos quais estão sujeitos.

Pesquisa do Comitê Gestor da Internet no Brasil (2019) revelou que, embora a maioria de usuários jovens se considerasse experiente em relação às dinâmicas das redes $^{1}$, apenas $32 \%$ dos professores concordou que seus alunos sabiam avaliar o que deveria ou não ser compartilhado pela Internet e 38\% deles afirmou já ter auxiliado algum estudante a enfrentar situações incômodas na rede. A exposição de crianças e adolescentes aos apelos da publicidade e conteúdos sensíveis como contato com desconhecidos, estímulo à automutilação e suicídio, perda de peso de forma exagerada, cyberbullying, etc., indicam que a inclusão desses temas nos currículos

$1 \quad$ Uma proporção de $88 \%$ de crianças e adolescentes afirmou saber definir o que devia ou não compartilhar na Internet. Na faixa etária entre 11 a 12 anos 51\% das crianças declarou saber verificar se uma informação encontrada na Internet era verdadeira, proporção que sobe para $76 \%$ dos adolescentes de 15 a 17 anos (CGIbr, 2019). 
e práticas escolares torna-se necessária. É preciso conhecer o funcionamento das Tecnologias Digitais de Informação e Comunicação (TDICs) para que a manipulação e a cooptação por interesses de outros seja minimizada ou, melhor ainda, evitada.

Este capítulo tem por objetivo analisar as contribuições da produção audiovisual estudantil com o uso das TDICs como metodologia ativa no processo de ensino e aprendizagem de Geografia com base em pesquisas de Neurociência, Educação e Comunicação. Desejamos poder contribuir para o aprofundamento, qualificação e inclusão da Educação Midiática e Informacional (EMI) no Ensino Fundamental. Defenderemos a ideia de que a utilização das TDICs por meio da produção audiovisual, para além de recurso pedagógico, é um conteúdo necessário e inadiável na contemporaneidade. Um caminho pelo qual estudantes possam acessar, compreender e dominar o universo da cultura dos meios digitais e informacionais e assim, estarem aptos ao exercício da cidadania.

\section{EDUCAÇÃO MIDIÁTICA E INFORMACIONAL (EMI)}

A Educação Midiática e Informacional (EMI) busca promover o uso das TDICs nas escolas e estimular os estudantes a serem participantes informados e letrados midiáticos em suas sociedades (KELLNER e SHARE, 2008). A EMI tem adquirido relevância nestes últimos anos e busca contribuir para que as pessoas possam, não apenas, acessar e compartilhar conteúdos diversos veiculados nas diferentes mídias, como também analisá-los de maneira crítica e consciente.

Os primeiros estudos nessa área começaram a ser desenvolvidos na década de 1930 quando o professor Edgar Dale, um dos pioneiros nesta área, publicou um artigo sobre a apreciação de filmes no ensino médio. Mais tarde, em seu livro Audiovisual methods in teaching, de 1954, ele elabora diversas sugestões para o planejamento, condução e avaliação de práticas pedagógicas relacionadas ao uso de métodos audiovisuais, ressaltando também a importância do uso de metodologias ativas para uma aprendizagem efetiva.

Na década de 1970, Marshall McLuhan apresentou a ideia de que os meios são elementos tão ou mais importantes do que os próprios conteúdos das mensagens por promoverem relações com os seres humanos em uma espécie de mecanismo 
construtor de mundos, anterior à interpretação pela razão. Para ele os efeitos da tecnologia se manifestam nas relações entre sentidos e estruturas de percepção, sendo que as transformações dos meios acabam tendo mais influência na comunicação do que as alterações nos próprios conteúdos.

Na década seguinte, a Organização das Nações Unidas para a Educação, a Ciência e a Cultura (United Nations Educational, Scientific and Cultural Organization - UNESCO) e o Fundo das Nações Unidas para a Infância (United Nations Children's Fund - UNICEF) também passaram a recomendar a necessidade da incorporação da aprendizagem das mensagens midiáticas e de sua leitura crítica nas escolas. Ou seja, no campo da Educação, as TDICs não devem ser compreendidas apenas como recurso didático-pedagógico, pois elas em si mesmas constituem, cada vez mais, nossa realidade e nos colocam frente ao grande desafio de sua compreensão.

No Brasil, os Parâmetros Curriculares Nacionais (PCNs - 1998) observavam que a produção de audiovisuais pelos estudantes, favorece a interação, a cooperação, a criação e a sistematização de resultados. A produção audiovisual integra diferentes conhecimentos e entra como uma nova linguagem e uma forma de compreender e representar o mundo em que vivemos. Ela também contribui para o desenvolvimento de processos metacognitivos levando os estudantes a "pensarem sobre o pensar", refletindo sobre suas próprias atividades como sujeitos e afirmando sua consciência como sujeitos da atividade (OLIVEIRA, 2014).

Atualmente, a Base Nacional Comum Curricular (BNCC) também recomenda a utilização das linguagens visual, sonora e digital para a produção de sentidos, assim como a compreensão, utilização e criação de TDICs "de forma crítica, significativa, reflexiva e ética para se comunicar, acessar e disseminar informações, produzir conhecimentos, resolver problemas e exercer protagonismo e autoria na vida pessoal e coletiva" (BRASIL, 2017, p. 9). O texto associa duas competências básicas a serem adquiridas pelos estudantes por meio da EMI: a capacidade de realizar uma análise crítica das mídias e dominar os elementos indispensáveis relativos a uma produção midiática, qualificada como democrática e participativa. O texto ressalta ainda que a execução dessas premissas necessitará de outros saberes que não apenas aqueles tradicionalmente atribuídos aos professores e a adoção de estratégias dinâmicas, interativas e colaborativas em relação à gestão do ensino e da aprendizagem. 


\section{PAPEL DA EDUCAÇÃo}

A educação escolar tem por uma de suas principais finalidades o desenvolvimento de novos conhecimentos e comportamentos. "Falamos em conhecimento toda vez que observamos um comportamento efetivo (ou adequado) num contexto assinalado. Ou seja, num domínio que definimos com uma pergunta (explícita ou implícita) que formulamos como observadores" (MATURANA e VARELA, 2011, p. 195). $A$ aquisição do conhecimento começa pelo processo de aprendizagem que envolve processos fisiológicos, cognitivos, emocionais e ambientais relacionados à maneira como cada um elabora esses estímulos, considerando sua capacidade de processar e integrar informações.

A compreensão do neurodesenvolvimento humano auxilia os professores a fazerem melhores usos de teorias e práticas educacionais de modo a incorporar metodologias e estratégias pedagógicas que expandam as potencialidades humanas de maneira criativa, autônoma e crítica permitindo ampliar e aperfeiçoar as capacidades dos estudantes. $O$ conhecimento sobre a organização do sistema nervoso, suas funções, seus sistemas de linguagem, atenção, memória, emoção, motivação e as relações entre cognição e desempenho, permite que se compreenda melhor como crianças e jovens aprendem e se desenvolvem e "como o corpo pode ser influenciado pelo que sentimos a partir do mundo e porque os estímulos que recebemos são tão relevantes para o desenvolvimento cognitivo, emocional e social" (COSENZA e GUERRA, 2011 p. 144). Cérebro e corpo constituem um organismo indissociável que formam um conjunto integrado por meio de circuitos reguladores bioquímicos e neurológicos que interagem em conjunto com o ambiente. "O fato de o ambiente ser, em parte, um produto da atividade do próprio organismo apenas coloca ainda mais em destaque a complexidade das interações que devemos ter em conta" (DAMÁSIO, 1994, p. 19).

No entanto, o conhecimento dos processos neurofisiológicos não traz uma receita para a construção de uma estratégia infalível a ser utilizada no ambiente escolar, mas há que se considerar que as estratégias eficientes serão aquelas que respeitem os princípios do funcionamento do cérebro para uma aprendizagem efetiva. A eficiência da consolidação da aprendizagem está relacionada à maneira como ela 
foi armazenada. Se "o processo de elaboração foi complexo, criando muitos vínculos com as informações existentes, haverá uma rede de interconexões mais extensa, que poderá ser acessada em múltiplos pontos, tornando o acesso mais fácil" (COSENZA e GUERRA, 2011, p. 72).

A utilização de diferentes estratégias e recursos didáticos é essencial para despertar a atenção de crianças e jovens, faixa etária para a qual a novidade e o contraste são elementos que lhes despertam curiosidade. Os professores têm que tornar os conteúdos de aprendizagem importantes também para os estudantes, ou seja, um dos primeiros desafios é fazer com que tenham o desejo e o interesse de estudar o que, em geral, é facilitado quando determinado conteúdo ou proposta pedagógica proporcione algum prazer. A criação de oportunidades em que o mesmo assunto possa ser examinado de diferentes maneiras e mais de uma vez é muito importante para o fomento de aprendizagens significativas.

\section{NEUROCIÊNCIAS JUSTIFICANDO AS METODOLOGIAS ATIVAS}

Pesquisas em Neurociências apontam que as ações educativas com base na atividade ampliam o potencial de desenvolvimento individual e acrescentam instrumentos eficazes no percurso da aprendizagem (OLIVEIRA, 2014). Num sentido amplo, toda aprendizagem é, em alguma medida, ativa, exigindo formas diferentes de movimentação interna e externa de percepção, atenção, memória, motivação, seleção, interpretação, comparação, reflexão, aplicação, avaliação, etc. Todavia, se nos voltarmos para uma compreensão específica daquilo que podemos chamar de metodologia ativa no campo pedagógico, verificamos que muitas propostas não poderiam ser classificadas como tal (MORAN, 2018).

Em seu sentido estrito as metodologias ativas devem estar comprometidas com a participação dos estudantes em processos que estimulem a curiosidade, proponham desafios e os levem, não apenas a realizarem algo, mas, principalmente, a refletirem sobre o que, como e porque fizeram de determinado jeito. "Construir o conhecimento é, literalmente, um processo ativo de pessoas envolvidas em ensinar e aprender. As pessoas constroem o conhecimento para utilizá-lo fazendo coisas no mundo" (OLIVEIRA, 2014, p. 20). 
A aprendizagem profunda "requer espaços de práticas frequentes (aprender fazendo) e de ambientes ricos em oportunidades. Por isso é importante o estímulo multissensorial e a valorização dos conhecimentos prévios dos estudantes para 'ancorar' os novos conhecimentos" (MORAN, 2018, p. 3). As propostas pedagógicas baseadas na atividade devem, prioritariamente, incentivar a aprendizagem constante e o pensamento reflexivo e crítico. Para além da simples memorização o pensamento crítico é aquele que decorre de uma análise, pela qual pode-se chegar a determinadas conclusões sem a necessidade de adaptação a modelos pré-estabelecidos, questionando-se as aparências e os efeitos de verdade sobre algo. No entanto, isso não quer dizer que outras formas de pensamento devam ser descartadas, pois as diversas formas de pensamento tais como os pensamentos divergente, convergente e criativo colaboram para a formação da criticidade.

Mas, para além de procedimentos e técnicas, as metodologias ativas precisam da autonomia do professor para criar atividades com potencial de promover experiências e aprendizagens. $\mathrm{Na}$ atividade docente o professor trabalha com diversos conhecimentos que envolvem tanto seu campo disciplinar específico, como também, relações interpessoais e pedagógicas tão dinâmicas quanto são as mudanças na sociedade, nas técnicas e na ciência. Os professores precisam estar continuamente atualizando seu conhecimento, num movimento constante e simultâneo ao dos estudantes, pois, "quem ensina aprende ao ensinar. E quem aprende ensina ao aprender" (FREIRE, 1996, p. 25). Eles devem combinar três tipos de conhecimento para a efetivação do processo de ensino-aprendizagem: domínio do conteúdo científico a ser ensinado; entendimento e aplicação das bases pedagógicas e teorias da aprendizagem de acordo com as características do público-alvo e; como esse conhecimento se aplica no cotidiano desse público (NÓVOA, 2016, apud NASCIMENTO et Al. 2019). O cérebro se dedica a aprender o que é significante para o sujeito, por isso importa fazer com que o novo conhecimento tenha ligações com o que já é conhecido e tido como importante para o aprendiz. "Terá mais chance de ser significante aquilo que tenha ligações com o que já é conhecido, que atenda a expectativas ou que seja estimulante e agradável" (COSENZA e GUERRA, 2011, p. 48).

A utilização das TDICs na Educação coloca o cérebro humano, "com tudo o que 
ele significa, em maior evidência ao se perceber a sua incrível capacidade de produzir sentido e complexidade compatíveis com os conhecimentos necessários tanto para o educando quanto para o educador do século XXI" (OLIVEIRA, 2014, p. 20). Todavia, há que se tomar muito cuidado para que sua utilização não ocupe o lugar de inúmeros outros elementos importantes na educação, como os jogos e as brincadeiras, a leitura e a escrita, a atividade física, as artes, as saídas de campo, as gincanas, as festas e confraternizações, entre tantas outras possibilidades. A incorporação das TDICs na educação, só tem sentido se for para contribuir para a melhoria da qualidade do ensino e, consequentemente, da aprendizagem. A mera presença de tecnologias digitais na educação não garante, por si só, uma maior qualidade na aprendizagem, pois a aparente modernidade pode mascarar um ensino baseado apenas na recepção e memorização de informações. É imprescindível "atuar de modo ativo no desenvolvimento das capacidades de raciocinar, interagir, planejar e autorregular-se, valorizando e respeitando a existência e as necessidades dos outros" (COSENZA e GUERRA, 2011, p. 96). O uso das TDICs não pode ser reduzido à mera aplicação de técnicas, embora possa limitar-se a isso, caso não haja uma reflexão sobre os objetivos de se utilizar os recursos tecnológicos nas atividades de ensino (BRASIL, 1998).

\section{A PRODUÇÃo AUdIOVISUAL COMO ESTRATÉGIA DE APRENDIZAGEM ATIVA}

Tudo que percebemos sem possuir um domínio técnico é absorvido por meio de sensações e não pela razão.

Alcides Dutra

As imagens sempre acompanharam a Geografia e seu processo educacional agindo "fortemente na atual partilha do sensível, realizada também nas narrativas em imagens acerca do mundo no qual vivemos" (OLIVEIRA Jr, 2009 apud RIBEIRO, 2013, p. 26). Em conjunto com a dinâmica espacial elas produzem efeitos de visibilidade e invisibilidade que afetam nossa percepção. Ao mesmo tempo em que podemos aprender com as imagens podemos também desaprender com elas, na medida em que conduzam nossos olhares e pensamentos. 
A linguagem audiovisual é constituída por uma série de convenções que podem ser facilmente entendidas e assimiladas, principalmente em função das emoções que elas suscitam. Por um lado, ela é objetiva e racional, por outro, é subjetiva, emocional e fantasiosa, pretendendo nos fazer crer que tudo seja realidade, embora trabalhe com efeitos de realidade. Filmes, sejam documentários ou obras de ficção, são resultados de um conjunto de recortes, seleções e perspectivas que envolvem interesses comerciais, estéticos, ideológicos, etc. e suas condições de produção têm que ser compreendidas e analisadas. É preciso desconstruir a ideia de que filmes de ficção não possam ter compromisso com a realidade e que documentários sempre serão o retrato fiel de alguma realidade. Toda e qualquer linguagem não é a realidade em si mesma, mas sim, criação simbólica. Por meio da linguagem as pessoas criam mundos de significação e não simplesmente o refletem (GONÇALVES, 2006). Embora os objetos materiais e as práticas sociais existam fora da linguagem, eles somente são evidenciados pela linguagem.

A maioria das crianças e jovens sabe operar um smartphone, uma câmera digital ou um computador, mas, na maioria das vezes, não conhece os conceitos básicos da linguagem audiovisual. Como instrumento de ação pedagógica, a produção audiovisual pelos estudantes, contribui para a promoção da tomada de consciência sobre os elementos e os usos das imagens, pois produzir filmes estimula o pensamento e a reflexão (MORAN, 1995). A produção audiovisual desenvolve a percepção visual e disciplinar o olhar, proporcionando a retomada de um processo crítico de ver, pois

a teoria é apenas isso: um ver concentrado e repetido, um ver que sabe ver, que inventa meios para ver cada vez melhor. E é nessa educação do olhar, a partir dela, que se institui toda a filosofia e as ciências do Ocidente e até mesmo o saber voltado para o prático. (BORNHEIM, 1988, p. 89)

Filmar é uma experiência muito envolvente e os estudantes podem ser incentivados a produzir programas informativos, representações espaciais, organizações sociais, transformação do espaço, etc., em um trabalho disciplinar ou interdisciplinar (MORAN, 1995). A produção audiovisual possibilita que os estudantes trabalhem em grupo, desenvolvam o sentido estético e se expressem por meio de uma linguagem que incorpora sons e imagens. Considerando a tendência gregária de crianças e jovens, os trabalhos colaborativos estimulam a confiança no grupo e a produção de 
um filme se encaixa perfeitamente nisso, pois é um trabalho predominantemente coletivo. A interação social é importante tanto para o desenvolvimento dos diversos tipos de pensamento, como também para a construção de nossa identidade corpórea. Adolescentes são extremamente sociais e a construção de projetos em equipe cria vínculos com o ambiente em que estamos. A interação dos estudantes amplia a aprendizagem e os resultados. A interação nos torna humanos (SARTÓRIO, 2020).

Todavia, devemos ter em mente que, a presença intensiva das mídias faz com que, num primeiro momento, ao idealizarem e planejarem suas produções, os estudantes possam vir a buscar referências nas próprias mídias a que têm acesso e reproduzam muitos desses elementos. Normalmente eles partem de seus referenciais e conhecimentos prévios de acordo com suas vivências e experiências, cabe aos professores problematizarem as situações apresentadas incluindo reflexões sobre cultura e produtos culturais.

Ao produzirem seus próprios filmes os jovens deixam de ser objetos de representações da mídia hegemônica para se tornarem sujeitos com o poder de contar suas próprias histórias, assumindo o papel de produtores. A produção de mídia alternativa possibilita aos estudantes o poder de criar suas próprias mensagens que podem desafiar os textos e as narrativas das mídias hegemônicas (KELLNER e SHA$\mathrm{RE}, 2008$ ). Dessa maneira, promove-se um pensar competente e autônomo, que contribui para a construção do conhecimento e emancipação dos sujeitos levando-os ao protagonismo e à autoria. Os estudantes passam a assumir um papel ativo em sua própria formação em vez de serem vistos como meros espectadores. Isso contribui para transformar passividade em atividade e torna a aprendizagem mais significativa, pois "ensinar não é transferir conhecimento, mas criar as possibilidades para a sua produção ou a sua construção" (FREIRE, 1996, p. 25).

A produção audiovisual mobiliza diversos processos mentais nos quais os produtos finais são os meios para se atingir a aprendizagem (NASCIMENTO, 2018). Assim como algumas linguagens são tradicionalmente utilizadas na escola, a educação para a leitura crítica das mídias não pode mais estar ausente do processo pedagógico. As mudanças que as tecnologias digitais e a cibercultura nos colocam diariamente fazem com que a aprendizagem dessa linguagem seja, cada vez mais, essencial e a educação escolar não pode ficar à margem e, muito menos, excluída 
desse processo.

Mas para produzir um audiovisual basta entregar uma câmera para os estudantes? O que se quer alcançar? Um primeiro alerta que deve ser feito é que a produção de um audiovisual demanda dedicação, comprometimento e precisa seguir todos os passos para sua realização, passando pela elaboração do argumento, roteiro, cronograma de cenas e áudios, iluminação, captação de imagens e sons, decupagem, edição e montagem, culminando com a exibição do filme (Figura 1). Para isso os estudantes necessitam trabalhar em equipe, pesquisar, fazer escolhas e refletir sobre o assunto a ser tratado durante todo o processo para que o resultado final possa ser compreendido por outros. Assim, trabalham de maneira simultânea com dois campos de conhecimento: o da Linguagem Audiovisual em si e o do conteúdo do filme a ser feito. A linguagem audiovisual "desenvolve múltiplas atitudes perceptivas e solicita constantemente a imaginação como um papel de mediação e a produção de filmes trabalha com ambas" (MORAN, 1995, p. 3).

Figura 1 - Professora e estudantes conversando sobre roteiro de filme.

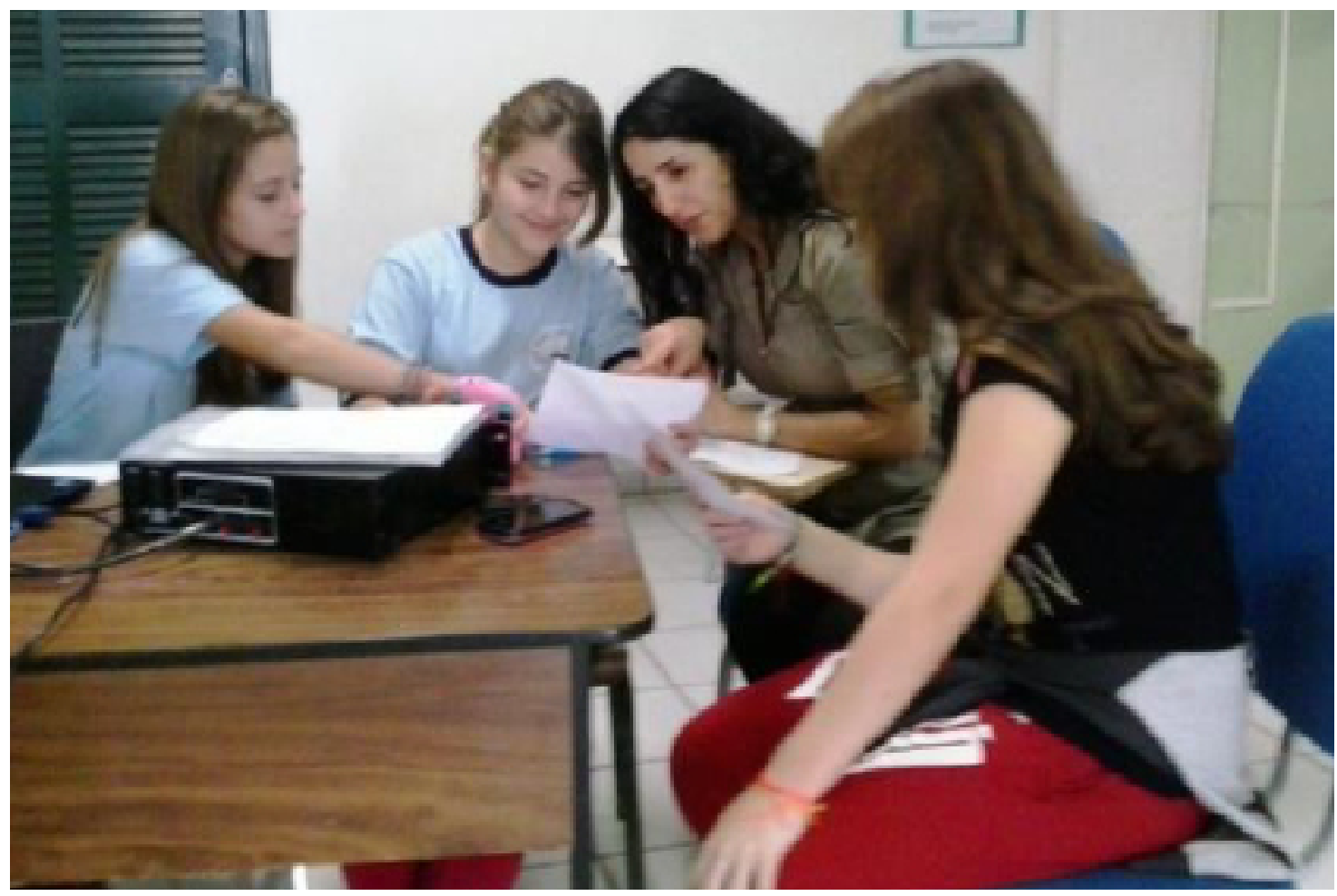

Fonte: Foto do autor (2015).

A captação de imagens estabelece um estranhamento entre o ambiente e seu uso habitual, permitindo, então, explicitar, não só a paisagem, mas a seleção dos seus ângulos, planos e enquadramentos (Figura 2). A percepção por meio de ima- 
gens, fragmentos da realidade, leva à surpresa que rompe o habitual. A

comparação entre fragmentos espaciais, entre a atual e a pregressa experiência [...], ao flagrante de pontos de contacto e diferenças de espaços e experiências e à ênfase ao realce de traços, dimensões, cores, texturas, fluxos, valorizados na composição de um uso. (FERRARA, 1988, p. 77)

Figura 2 - Estudantes gravando cena de filme.

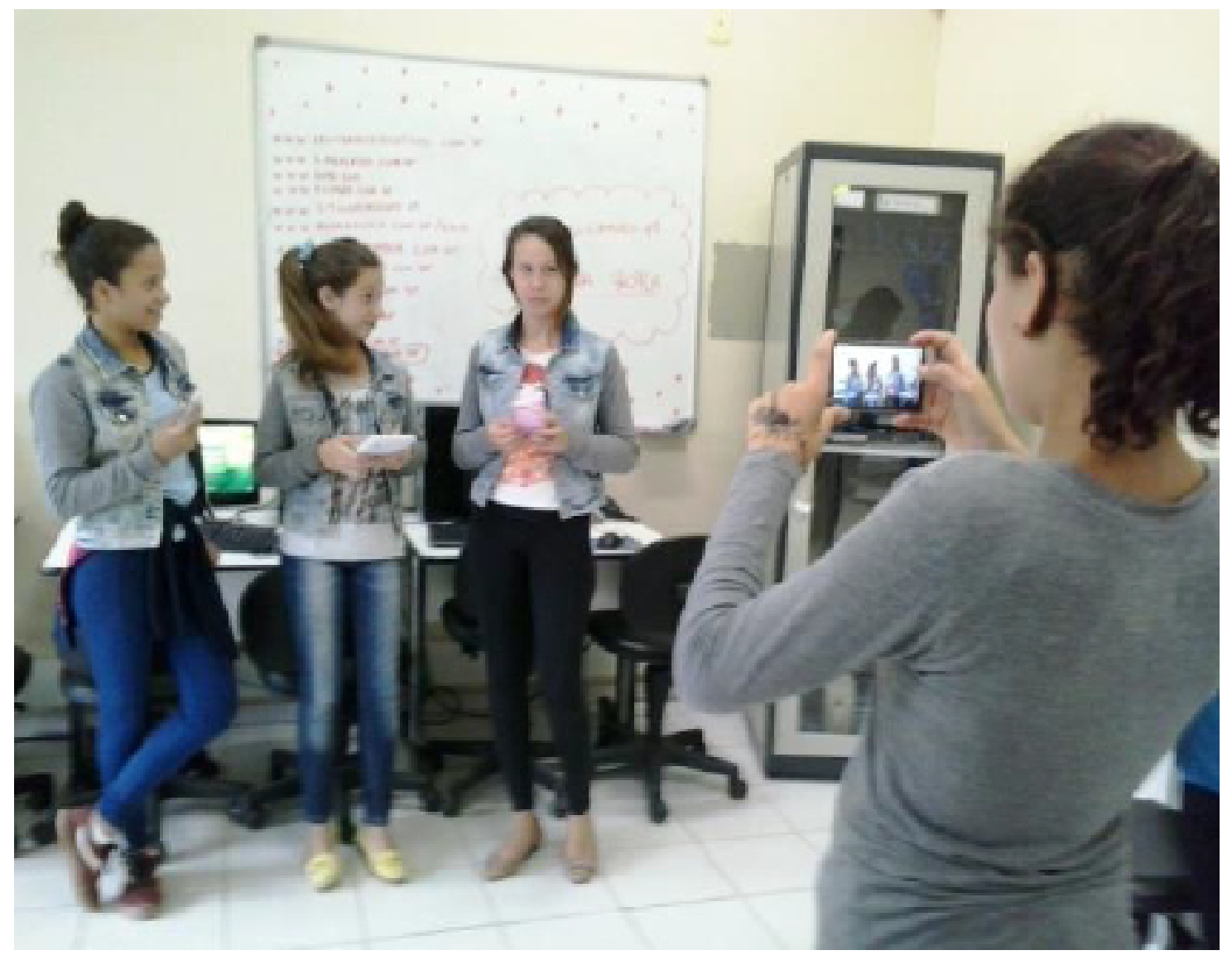

Fonte: Foto do autor (2015).

A incorporação da produção audiovisual na educação geográfica escolar oferece

o potencial para tornar o aprendizado mais experimental, mais mão-na-massa, criativo, expressivo e divertido. A educação em arte midiática pode trazer prazer e cultura popular para a educação corrente, tornando a escola, assim, mais motivadora e relevante para os alunos. (KELLNER e SHARE, 2008, p. 700)

Os estudantes ficam muito motivados quando utilizam recursos tecnológicos, pois estes introduzem novas possibilidades na atividade de ensino-aprendizagem. $A$ valorização do indivíduo amplia nossa motivação e aumenta a capacidade de apren- 
dizagem (NASCIMENTO et. Al., 2019). Os processos motivacionais gerados por emoções positivas como o entusiasmo, a curiosidade, o envolvimento e a satisfação por atingir certos objetivos têm grande influência na aprendizagem e na memória. A "curiosidade, o que é diferente e se destaca no entorno, desperta a emoção. E, com a emoção, se abrem as janelas da atenção, foco necessário para a construção do conhecimento" (MORAN, 2018, p. 3).

\section{CONCLUSÃO}

Os estudantes se interessam e gostam de fazer audiovisuais por sua dimensão atual e lúdica, cabendo à escola incentivá-los e orientá-los neste processo. A linguagem audiovisual desenvolve múltiplas atitudes perceptivas e solicita constantemente a imaginação como um papel de mediação. Por meio da produção audiovisual procura-se construir uma postura ativa que possa contribuir para a superação do consumo passivo das imagens e da informação.

$\mathrm{O}$ ato de fazer amplia o grau de envolvimento dos estudantes no processo de aprendizagem resultando numa maior consolidação do conhecimento, enquanto uma participação mais passiva leva a uma retenção menor. A prática cativa mais a atenção do que a exposição oral e permite novas descobertas e interpretações para os fenômenos. Esse "aprender fazendo" é algo que nos interessa, pois essa é a base da proposta da produção audiovisual para uma Educação Midiática e Informacional crítica aqui defendida.

O cérebro humano cria e recria seus circuitos nervosos, moldando-se plasticamente de acordo com os estímulos do ambiente. Os processos cognitivos estão profundamente entrelaçados com as emoções, mobilizando a atenção e a percepção e determinando a escolha das ações que se seguirão. A produção audiovisual, como atividade pedagógica, contribui para disciplinar o olhar, desenvolver a percepção visual e proporcionar a retomada de um processo crítico de ver ao integrar diferentes conhecimentos, estimular o trabalho em grupo e levar à superação da timidez, ao exercício do protagonismo e à autoria, valorizando estudantes e professores.

O uso das TDICs na educação geográfica pode trazer benefícios como o maior acesso à informação, a consolidação de canais de expressão e a valorização de 
identidades. O desenvolvimento das diversas atividades cerebrais com uso dos diferentes sentidos amplia a aprendizagem, mas é necessária a construção de um ambiente que além de garantir a convivência responsável nesse espaço contemple também o desenvolvimento de habilidades que possibilitem uma participação ativa, responsável e crítica.

As Tecnologias Digitais da Informação e Comunicação são instrumentos pelos quais se pode libertar ou dominar, manipular ou esclarecer e é fundamental que os educadores ensinem seus alunos a usá-las e analisá-las. A produção audiovisual pelos estudantes, além de ferramenta ou recurso pedagógico, é um conteúdo necessário que pode contribuir para a reflexão e a análise crítica das mídias, da produção e distribuição da informação, constituindo-se numa estratégia eficaz para o conhecimento do funcionamento da atual sociedade. A educação escolar não pode estar alheia a esses processos e suas implicações, sendo necessário não apenas educar com as mídias, como também educar para as mídias. Postulamos que a escola deva assumir seu papel transformador e, assim como outras linguagens são contempladas no currículo e no processo pedagógico, a Educação Midiática e Informacional possui grande importância e não pode deixar de ser considerada.

Embora não seja nem um pouco adequado que TDICs tomem o lugar de tantas outras atividades necessárias para o desenvolvimento de crianças e adolescentes, seu uso responsável pode contribuir para o enriquecimento do desenvolvimento desse período da vida desde que se leve em consideração o nível e desenvolvimento cognitivo dos estudantes e a capacidade de pais e professores realizarem um acompanhamento próximo e educativo desse uso. Cientes de que algumas práticas funcionam melhor para algumas pessoas do que para outras e que as diferentes faixas etárias requerem abordagens e atividades distintas não se pretende considerar a produção audiovisual como sendo um recurso universal e acima dos outros, mas sim, como mais uma possibilidade de intervenção pedagógica ativa que tem por objetivo ampliar a capacidade dos estudantes na compreensão da realidade, inclusive de seu cotidiano. Defendemos a importância de uma educação que, para além de utilizar as tecnologias, comece também a analisá-las e questioná-las, dada a complexidade de todo esse sistema, especialmente para crianças e adolescentes. 
Vivemos em sociedade e a escola é uma de suas principais instituições, o que nos permite ter a convicção de estarmos contribuindo para a reflexão e consequente mudança de atitude de nossos estudantes, reforçando o papel educacional da escola e seu potencial transformador. Consideramos que todo esforço realizado continuará trazendo benefícios diretos e indiretos não apenas para a escola, para estudantes e professores envolvidos como também para nossa sociedade como um todo.

\section{REFERÊNCIAS}

BORNHEIM, Gerd A. As metamorfoses do olhar. In O olhar. NOVAES, A. (org.) São Paulo: Companhia das Letras, 1988.

BRASIL. Base Nacional Comum Curricular. Secretaria de Educação Fundamental. Brasília: MEC/SEF, 2017.

. Parâmetros Curriculares Nacionais: terceiro e quarto ciclos do ensino fundamental: introdução aos PCN / Secretaria de Educação Fundamental. Brasília: MEC/SEF, 1998.

CGI.br. Pesquisa sobre o uso da Internet por crianças e adolescentes no Brasil: TIC kids online Brasil 2018 / Núcleo de Informação e Coordenação do Ponto BR, [editor]. -- São Paulo: Comitê Gestor da Internet no Brasil, 2019. Disponível em: https://cetic.br/media/docs/publicacoes/216370220191105/tic_kids_online_2018_livro_eletronico.pdf. Acesso em: 31 ago. 2020.

COSENZA, Ramon M. \&, GUERRA, Leonor B. Neurociência e Educação: como o cérebro aprende. Porto Alegre: Artmed, 2011.

DALE, Edgar. Audiovisual methods in teaching. New York: Dryden Press, 1954.

DAMÁSIO, António R. 0 erro de Descartes: emoção, razão e o cérebro humano. São Paulo: Companhia das Letras, 1994.

FERRARA, Lucrécia A. Ver a cidade: cidade, imagem, leitura. São Paulo: Nobel, 1988.

FREIRE, Paulo. Pedagogia da autonomia: saberes necessários à prática educativa. São Paulo: Paz e Terra, 1996. 
ção. Rio de Janeiro: Civilização Brasileira, 2006.

IBGE. Pesquisa Nacional por Amostra de Domicílios Contínua - PNAD Contínua investigou no quarto trimestre de 2018. 2020. Disponível em: https://biblioteca. ibge.gov.br/visualizacao/livros/liv101705_informativo.pdf. Acesso em: 23 set. 2020.

IBGE. Acesso à internet e à televisão e posse de telefone móvel celular para uso pessoal: 2016. IBGE, Coordenação de Trabalho e Rendimento. Rio de Janeiro: IBGE, 2018. Disponível em: https://biblioteca.ibge.gov.br/visualizacao/livros/ liv101543.pdf. Acesso em: 8 mai. 2019.

KELLNER, Douglas \& SHARE, Jeff. Educação para a leitura crítica da mídia, democracia radical e a reconstrução da educação. Educ. Soc., Campinas, v.29, n.104, 2008.

MATURANA, Humberto R. e VARELA, Francisco J. A Árvore do conhecimento: as bases biológicas do entendimento humano. São Paulo: Palas Athena, $9^{a} \mathrm{Ed}$. 2011.

MCLUHAN, Marsall. Os meios de comunicação: como extensões do homem. São Paulo: Cultrix, 1974.

MORAN, José in BACICH, Lilian e MORAN José. (Org.). Metodologias ativas para uma educação inovadora. Porto Alegre: Penso, 2018.

O vídeo na sala de aula. Revista Comunicação \& Educação. São Paulo: ECA-Ed. Moderna, [2]: 27 a 35, jan./abr. de 1995.

NASCIMENTO, Rosemy S., SARTÓRIO, Rodrigo \& CLAUDINO, Sérgio Aprendizagem na Educação Geográfica à luz da neurociência: as experiências "A escola faz o vídeo", “Com-vida" e “Nós Propomos!”. In: Geografia, Educação e Cidadania (pp. 473-489). Lisboa: Centro de Estudos Geográficos, 2019.

Disciplina Recursos Didáticos. Profa. Dra. Rosemy da Silva Nascimento. Programa de Pós-Graduação em Geografia - PPGG - UFSC. Anotações de aula, 2018.

OLIVEIRA, Gilberto G. Neurociências e os processos educativos: um saber necessário na formação de professores. In Educação Unisinos 18(1):13-24, janeiro/abril 2014. Disponível em: http://revistas.unisinos.br/index.php/educacao/article/ viewFile/edu.2014.181.02/3987 - Acesso em: 24 jun. 2020.

RIBEIRO, Roberto S. Geografia e imagem: a foto-sequência como metodologia 
participativa no $9^{\circ}$ ano do ensino fundamental de geografia. Dissertação: Florianópolis: UFSC, 2013.

SARTORIO, Rodrigo. O corpo aprende: neurociência e educação. [S. I.: s. n.], 2020. 1 vídeo (59 min). Publicado pelo canal Rosemy da Silva Nascimento. 4 jun. 2020. Disponível em: https://www.youtube.com/watch?v=Uc-34NPCLxE - Acesso em: 28 jul. 2020.

WILSON, Carolyn. et al. Alfabetização midiática e informacional: currículo para formação de professores. Brasília: UNESCO, UFTM, 2013. 


\section{O PROCESSO DE AVALIAÇÃO NO ESTÁGIO SUPERVISIONADO EM ENSINO DE GEOGRAFIA}

FÁBIO FERREIRA SANTOS

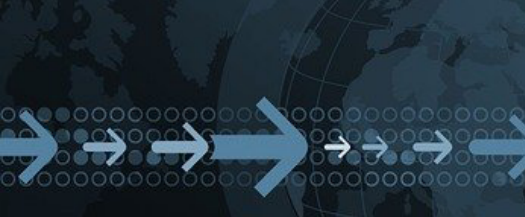

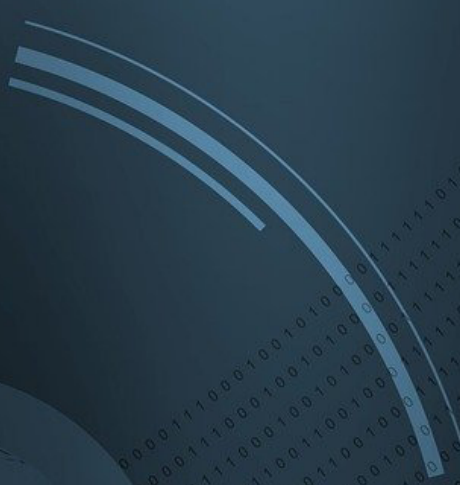

1 - Doutor em geografia pela Universidade Federal da Paraíba e professor da rede pública de ensino municipal no município de Itabaiana _ SE. 


\section{INTRODUÇÃO}

Os aspectos do desempenho dos alunos que as escolas escolhem para avaliar refletem muito claramente as funções requeridas de um sistema educativo especifico. As práticas de avaliação constituem um dos mais claros indicadores da relação entre a escola e a sociedade, pois elas não são apenas as práticas de avaliação pedagógica. Ela é algo mais amplo, pois inclui não só as práticas avaliativas mais diretamente dependentes do professor, e que são direcionadas para o interesse dos alunos, como também as práticas de avaliação de outros atores e do próprio sistema educativo.

Segundo Broadfoot apud Afonso (2005),

[...] a avaliação deve abranger toda a variedade de atividades avaliativas no contexto do sistema educativo, desde os julgamentos que o professores fazem sobre cada aluno na sala de aula, até aos vários e mais formais modos de julgar o processo dos alunos na escola como um todo, que possibilitam a responsabilidade do professor, da escola, das autoridades locais e, em ultima instancia, de todas as formas de provisão da educação a nível nacional. [...] (BROADFOOT apud AFONSO, 2005, p. 198)

Partindo dessa perspectiva, podemos verificar dois importantes fatores para a avaliação educacional: o primeiro que se refere às práticas avaliativas que apóiam as aprendizagens dos alunos ou que justificam o poder de avaliar dos professores; o outro diz respeito à problemática da relação práticas de avaliação (pedagógica) com as diferentes formas de prestação de contas do sistema educativo.

A avaliação dos sistemas educativos aparece associada à responsabilização pelos resultados escolares dos alunos. Esta prática acaba contribuindo para a divulgação de uma associação entre conceitos que são diferenciados: se a prestação de contas pressupõe os resultados obtidos através da avaliação, esta última não implica necessariamente a prestação de contas. Sendo assim, a relação avaliaçãoresponsabilidade faz com que a primeira se desenvolva e adquira maior visibilidade em épocas que os movimentos de reforma educacional exigem uma maior participação e controle sobre a implementação das políticas para a educação. 


\section{A aVAliação pedagógica no estagio SUPERVISIONAdo em GEOGRAFIA}

As discussões recentes sobre a avaliação na escola apontam para a certeza de que avaliar não deve corresponder a determinados momentos da aprendizagem escolar, voltados para a classificação do aluno, geralmente por meio de notas. Neste caso, a avaliação tem o papel apenas de verificar os resultados objetivos dos conteúdos trabalhados e documentar o desempenho escolar, construindo em um fim em si mesmo.

Segundo Filho,

a avaliação escolar do desempenho dos estudantes tem determinado grande parte das relações que se dão entre professores, alunos, suas famílias e a direção escolar. É o aspecto mais complexo e controverso das praticas pedagógicas (Jordão, 1995). Ela determina e é o coração (centro) de todo o processo de ensino e aprendizagem. (2000, P.14)

A avaliação é muito mais do que um momento para a aplicação de um instrumento avaliativo, é um processo. Tratando-se de um universo de aspectos, desde a relação professor-aluno até os instrumentos, passando pelos critérios norteadores da avaliação, pela concepção que se tem de ensino, além da abordagem epistemológica da prática pedagógica. Sendo assim, considero a avaliação como um processo contínuo numa perspectiva diagnóstica.

Segundo Luckesi "a avaliação da aprendizagem existe propriamente para garantir a qualidade da aprendizagem do aluno. Ela tem a função de possibilitar uma qualificação da aprendizagem do educando." (LUCKESI, 2001, p. 66). Assim, a avaliação é uma apreciação qualitativa sobre dados relevantes do processo de ensino-aprendizagem que auxilia o professor a tomar decisões sobre o seu trabalho.

A avaliação qualitativa deve estar alicerçada na qualidade do ensino e pode ser feita para avaliar o aluno como um todo no decorrer do ano letivo, observando a capacidade e o ritmo individual de cada um. Desta forma, para haver uma avaliação qualitativa e não classificatória deve acontecer uma mudança nos paradigmas de ensino em relação à democratização do excesso da educação escolar e com isso haverá uma qualidade de ensino do educando onde acontecerá um sentido de evolução produtiva nos processos avaliativos. 
Nesse ponto Luckesi afirma que, (“...) a atual prática da avaliação escolar tem estado contra a democratização do ensino, na medida em que ela não tem colaboração para a permanência do aluno na escola e a sua promoção qualitativa." (LUCKESI, 2001, p. 66).

Nesse sentido, a avaliação escolar é um componente de ensino que visa, através da verificação e qualificação de resultados obtidos, na qual tende a determinar a correspondências destes com os objetivos propostos, e, por conseguinte orientar a tomada de decisões em relação às diversas atividades didático-pedagógicas.

Acredita-se que a avaliação deve ser vista não como um fim, mas como um meio de o professor identificar os avanços e as dificuldades do seu trabalho e reorientar sua prática pedagógica em busca dos objetivos da aprendizagem.

Os resultados produzidos no processo de uma avaliação devem prestar-se para uma "parada", um tempo para o professor chegarem sua própria prática. Com isso, os encaminhamentos considerados no planejamento do ensino podem ser revistos e retomados em novas bases, tendo em vista assegurar melhorias na forma de conduzir ou de ensinar um dado conteúdo.

Em consonância com Luckesi (2001), acredito que a avaliação da aprendizagem escolar deve ser um "ato amoroso", tendo dois objetivos principais: "auxiliar o educando no seu desenvolvimento pessoal, a partir do processo de ensino-aprendizagem e, responder à sociedade pela qualidade do trabalho educativo realizado".

De um lado, a avaliação da aprendizagem corresponde ao auxilio ao educando no seu crescimento, sendo um suporte para o educando no seu processo de assimilação dos conteúdos e no seu processo de constituição como sujeito e cidadão perante a sociedade.

Por outro lado, a avaliação da aprendizagem permite uma interação ou a alienação entre professor-aluno na construção da aprendizagem. Aliás, a avaliação da aprendizagem responde a uma necessidade social que se articula com o coletivo para desenvolver um ensino de qualidade na escola.

Em relação a essa análise, Luckesi (2001) ressalta que:

[...] a avaliação da aprendizagem escolar auxilia o educador e o educando na sua viagem comum de crescimento, e a escola na sua responsabilidade social. Educador e educando, aliados, constroem a aprendizagem, testemunhando-a a escola, e esta á sociedade. A avaliação da aprendizagem neste 
contexto é um ato amoroso, na medida em que inclui o educando no seu curso de aprendizagem, cada vez com qualidade mais satisfatória, assim como na medida em que o inclui entre os bem-sucedidos, devido ao fato de que esse sucesso foi construído ao longo do processo de ensino-aprendizagem (o sucesso não vem de graça). A construção, para efetivamente ser construção, necessita incluir, seja do educando, seja do ponto de vista coletivo, integrando o educando num grupo de iguais, o todo da sociedade. (LUCKESI, 2001, p.175)

Nesse âmbito, observa-se a relação ensino-aprendizagem como meio articulador do saber do educando pode variar conforme as necessidades adquiridas durante o processo de aprendizagem que se faz presente no contexto da avaliação educacional.

Acredito que a avaliação deve ser vista não como um fim, mas como um meio de o professor identificar os avanços e as dificuldades do seu trabalho e reorientar sua prática pedagógica em busca dos objetivos da aprendizagem.

Conforme ressalta zabala (1998):

o conhecimento do que cada aluno sabe, sabe fazer e como é, é o ponto de partida que deve nos permitir, em relação aos objetivos e conteúdos de aprendizagem previstos, estabelecer o tipo de atividades e tarefas que têm que favorecer a aprendizagem de cada menino e menina. (ZABALA, 1998, p.199)

No processo de avaliação, o planejamento do ensino torna-se um instrumento importante que transmiti ao professor uma maior segurança em conduzir a sua prática educacional. Assim, os objetivos do ensino-aprendizagem pode-se ser transmitido de forma esclarecedora e capaz de produzir um ensino de qualidade na escola.

\section{COMO AVALIAR O ALUNO?}

A avaliação por ser uma atividade constante na vida das pessoas, sejam elas profissionais, como professores, médicos, estudantes, etc. Isso não significa que um professor sempre saiba avaliar o desempenho do aluno.

Ristoff mostra que "a avaliação é um processo para determinar até que ponto os objetivos educacionais foram realmente alcançados." (2003, p.32). Nesse aspecto, a avaliação é algo em construção para a verificação de objetivos, através de processos pré-estabelecidos.

Quando os professores praticam a avaliação, a maneira de acolher as informa- 
ções sobre a aprendizagem dos alunos pode ser realizada por uma pluralidade de métodos e técnicas que incluem desde o recurso à memória que o professor guarda das características dos alunos até as mais diversificadas e conhecidas estratégias como a observação, a auto-avaliação, a entrevista, o trabalho de grupo, a pesquisa feita em casa, as tarefas em classe e outras formas diferentes de interação pedagógica. Dessa forma, Afonso salienta que,

se o professor pretende identificar problemas sentidos pelos seus alunos, se, em vez de constatar a existência de dificuldades, pretende entendê-las e enfrentá-las, terá que recorrer o mais possível a diferentes estratégias de análise e registro do que se está a passar na sala de aula. (AFONSO APUD CORTESÃO, 2005, p. 38)

Observando esse ponto de vista, percebe-se que o campo de avaliação é muito amplo e possibilita o reconhecimento da pluralidade de formas de excelência escolar no âmbito da avaliação pedagógica.

A partir dessa concepção percebemos que no ensino de Geografia perpassa por diversas modalidades que constituem o processo de avaliação, pelo qual o aluno busca interagir para se inserir no processo de ensino-aprendizagem.

No Estágio Supervisionado em Ensino de Geografia, foram usados varias estratégias para avaliar o aluno, na qual a avaliação ocorria semanalmente como uma forma de auxiliar o ensino-aprendizagem do aluno. Desse modo alguns métodos avaliativos foram usados no estágio.

A avaliação não é um método, mas sim um procedimento utilizado no âmbito escolar para diagnosticar o rendimento individual e grupal dos alunos e, consequentemente, da escola. $O$ que existem são muitos métodos, muitas formas de avaliar, dentre as quais a avaliação escrita faz parte, sendo um dos instrumentos mais antigos do processo avaliativo.

A prova escrita é uma forma "eficaz" de avaliar se o aluno aprendeu a matéria. Todavia, deve-se atentar-se as diferentes maneiras de desenvolve o conhecimento do aluno. Numa prova escrita onde às questões são dissertativas, verifica-se que o aluno desenvolve a capacidade de expressar suas ideias por escrito, estimulando a criatividade e seu raciocínio. Porém, nesse caso, a avaliação precisa ser mais "elástica", uma vez que não há uma respostas-padrão, ou seja, o professor deve-se atentar a acolher positivamente as tentativas de explicação do aluno. Já as questões de múl- 
tipla escolha devem ser acompanhadas de pedido de justificativas, com o propósito de o aluno expressarem suas ideias claramente.

A avaliação escrita é um importante momento de verificar-se a aplicação do conhecimento construído. É um conhecimento que deveria ser articulado de acordo com o que o aluno aprendeu e ele carrega consigo. O que é preciso obter do aluno para uma avaliação escrita é justamente fazer com que os mesmos utilizem o seu potencial explicativo e conscientize da necessidade de aplicar o seu conhecimento dos conteúdos para solucionar um determinado problema numa situação especifica. Dessa forma, passaríamos a ter uma vantajosa avaliação escrita capaz de avaliar a verdadeira compreensão do conhecimento do assunto que o aluno adquiriu.

A prova oral pode ser desenvolvida através de variadas maneiras. Uma delas é a entrevista, na qual o aluno desenvolve a sua capacidade de formular suas perguntas a respeito de determinados assuntos e tenham a oportunidade expressar-se oralmente. Outras formas de aplicar a prova oral podem ser através de questões respondidas oralmente, avaliando conhecimentos e habilidades de expressão oral. Por não haver registro e por ser uma avaliação imediata, a prova oral caracteriza-se, em relação às demais modalidades de avaliação, pela maior subjetividade.

Outra modalidade de avaliação é a autoavaliação. Essa modalidade estimula o aluno a refletir sobre seu próprio desempenho.

Para Lima (2008),

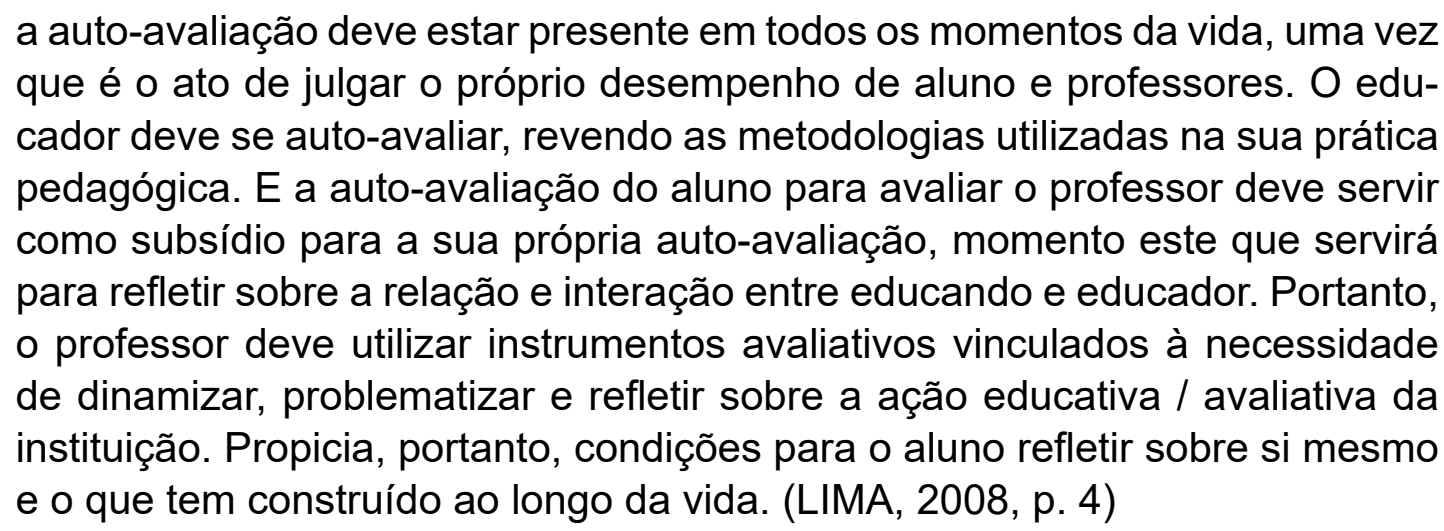

Nesse sentido, a autoavaliação para se tornar mais eficaz, deve ser orientada pelo professor, que poderá sugerir alguns itens para o aluno responder sobre si mesmo. Ela não deve ter mais peso que as outras notas da avaliação, uma vez que seu objetivo maior é treinar a reflexão crítica do aluno sobre suas próprias atitudes, e não 
medir o conhecimento formal.

Já o trabalho de pesquisa feito em casa, observa-se que eles devem ser avaliados com reserva, pois nem sempre é o aluno quem executa o trabalho, ou às vezes executa de forma errônea, através de colagens pela internet sem ler o assunto proposto na atividade de pesquisa. Sendo assim, são interessantes que, após a entrega, o aluno ou o grupo descrevam as etapas do trabalho, as dificuldades, as fontes, etc., ou ainda debatam na sala de aulas as principais ideias contidas no assunto de sua pesquisa.

O processo de participação está relacionado a um complemento das notas, que poderão ser atribuídos pontos ou conceitos sobre a participação do aluno em sala de aula, em trabalhos experimentais, em feiras de ciências, em pesquisa de campo, etc. essa modalidade vem sendo inserida na escola como um meio eficaz de inibir a reprovação dos alunos, pois na maioria das vezes os alunos se destacam nas atividades de participação como meio de ajudar na sua nota.

O fator comportamento é uma das modalidades controvertidas e polêmica a aplicação de conceitos sobre comportamentos e atitudes do aluno. No entanto, dependendo da turma, pode trazer benefícios para toda a classe, pela qual o professor se vê diante de uma situação que vem realmente perturbando o ensino. É importante que pontos de comportamento não tenham mais peso que as notas de avaliação, pois pode provocar um esvaziamento na forma didático-pedagógica de trabalho o conteúdo.

Desta forma, as diversas modalidades de avaliação permitem ao professor correlacionar às inúmeras situações de execução de avaliar o aluno, nas quais esses procedimentos possam desenvolver a capacidade dos educandos compreenderem o assunto proposto, e avançar na sua aprendizagem.

O processo de participação está relacionado a um complemento das notas, que poderão ser atribuídos pontos ou conceitos sobre a participação do aluno em sala de aula, em trabalhos experimentais, em feiras de ciências, em pesquisa de campo, etc. essa modalidade vem sendo inserida na escola como um meio eficaz de inibir a reprovação dos alunos, pois na maioria das vezes os alunos se destacam nas atividades de participação como meio de ajudar na sua nota. 
O fator comportamento é uma das modalidades controvertidas e polêmica a aplicação de conceitos sobre comportamentos e atitudes do aluno. No entanto, dependendo da turma, pode trazer benefícios para toda a classe, pela qual o professor se vê diante de uma situação que vem realmente perturbando o ensino. É importante que pontos de comportamento não tenham mais peso que as notas de avaliação, pois pode provocar um esvaziamento na forma didático-pedagógica de trabalho o conteúdo.

Desta forma, as diversas modalidades de avaliação permitem ao professor correlacionar às inúmeras situações de execução de avaliar o aluno, nas quais esses procedimentos possam desenvolver a capacidade dos educandos compreenderem o assunto proposto, e avançar na sua aprendizagem.

No estágio Supervisionado em Ensino de Geografia, a avaliação foi feita constantemente a partir de atividades como exercício, pesquisa, discussões em sala de aula e uma prova escrita. Todas essas atividades foram pontuadas de acordo com as normas estabelecidas no primeiro dia de aula. No final do estágio percebi que os alunos tiveram um bom rendimento escolar, e estavam conscientes dos temas abordados em sala de aula.

Fiquei satisfeito com o resultado obtido da turma, não só do ponto de vista quantitativo (relacionado às notas), mas também do ponto de vista qualitativo, pois a maior parte dos alunos teve um bom rendimento na sua aprendizagem.

\section{CONSIDERAÇÕES FINAIS}

O processo de avaliação é algo complexo, visto que avaliar o ser humano torna-se algo permanentemente em construção. Nesse ponto, o estágio supervisionado em geografia nos permitiu introduzir diversas maneiras e formas de avaliar o aluno, seja por avaliações tradicionalistas ou por novos métodos de avaliar a aprendizagem.

No tocante, é evidente que o ensino-aprendizagem decorre do esforço do aluno em aprender determinados conteúdos de ensino. Para tanto, o professor como sujeito que transmite o conhecimento devem-se estar atentado às dificuldades em que o aluno passa no decorrer da sua aprendizagem. Por isso, cabe ao profissional propor metodologias que insira o educando na composição do processo de avaliação. 
Em suma, é importante ressaltar que todo e qualquer sujeito que está inserido em uma sala de aula passa por inúmeros processos de avaliação, seja através da avaliação por disciplinas ou por estar encarando os desafios existentes no processo de aprendizagem. Portanto, o estágio é algo que proporcionou ao aluno e ao professor está atento às questões de como avaliar o aluno? E como esse aluno obteve a aprendizagem?

\section{REFERÊNCIAS}

AFONSO, Almerindo Janela; Avaliação educacional: regulação e emancipação: para uma sociologia das políticas avaliativas contemporâneas. 3 ed. - são Paulo; Cortez, 2005.

FILHO, Jomar Barros; SILVA, Dirceu; Algumas reflexões sobre a avaliação dos estudantes no ensino de ciências. In: Ciências e ensino; dezembro de 2000.

LIMA, João do Rozario; A importância da avaliação no ensino fundamental. Artigo científico publicado na USP; São Paulo, 2006.

LUCKESI, Cipriano Carlos; Avaliação da aprendizagem escolar: estudos e proposições. - 11. Ed. - São Paulo: Cortez, 2001.

RISTOFF, Dilvo, I (org.) Avaliação e compromisso público: Florianópolis: Insular, 2003, 21 - 33.

ZABALA, Antoni: A prática Educativa: como ensinar; tradução Ernani F. da F. Rosa-Porto Alegre: Artmed, 1998. 


\section{RECURSOS DIDÁTICOS NO}

\section{PROCESSO DE ENSINO E}

\section{APRENDIRAGEM DE GEOGRAFIA}

\section{ALISSON HENRIQUE BAVARESCO}

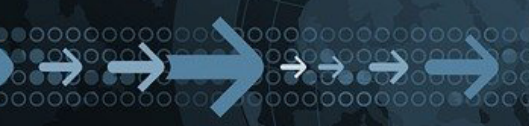

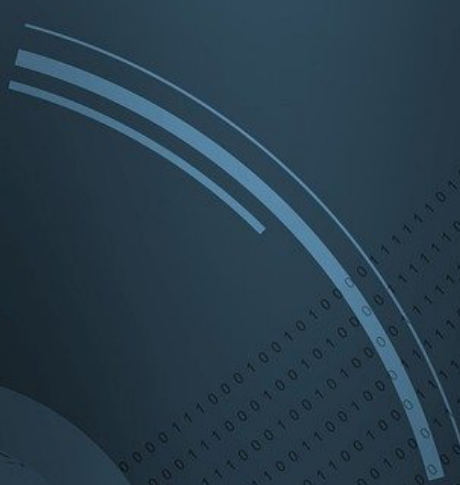

1 Trabalho apresentado em 2018 ao curso de Licenciatura em Geografia como requisito para a obtenção do título de licenciado em Geografia.

2 Professor da educação Básica do estado de Santa Catarina. Graduado em Geografia pela Universidade Estadual do Oeste do Paraná - UNIOESTE - campus de Francisco Beltrão. Mestrando do curso de Pós graduação em Geografia da UNIOESTE-campus de Francisco Beltrão. E-mail alisson_bava@hotmail.com 


\section{INTRODUÇÃO}

Neste trabalho analisaremos a partir de referencial bibliográfico a importância da utilização de recursos didáticos no ensino da Geografia, tentando compreender a importância no processo de ensino e aprendizagem. Com o intento de contribuir para melhorar o ensino e a aprendizagem de Geografia.

Partimos do pressuposto que "recurso didático é todo material utilizado como auxílio no ensino-aprendizagem do conteúdo proposto para ser aplicado pelo professor a seus alunos". (SOUZA, 2007, p. 111). De acordo com Anjos (2008), podem ser simples como giz, pincel e quadro de escrever, até mais elaborados como computadores e celulares, o importante é, segundo o autor, servir de canal entre as atividades docentes e o contexto discente. Tais recursos auxiliam os participantes nas construções cognitivas.

O grande desafio é saber se a utilização de recursos didáticos, como filmes, jogos, músicas, cartazes, poesias, debates, pesquisas, trabalhos de campo e demais atividades, diversas, realmente, auxiliam no processo de ensino e aprendizagem de Geografia. Acreditamos que uma aula bem estruturada é planejada pelo professor de modo que haja sintonia entre sua fala, os materiais por ele elaborados, e aqueles utilizados como suporte, durante a explanação dos conteúdos. São vários os tipos de recursos disponíveis que podem ser utilizados pelo professor, embora cada um necessite de planejamento e preparação para a sua funcionalidade.

Deste modo, o presente trabalho buscará explicitar as vantagens do uso de diferentes recursos didáticos no processo de ensino e aprendizado de Geografia, a partir das discussões realizadas por inúmeros autores dedicados à pesquisa no ensino e aprendizado. Dentre os autores que contribuíram para a discussão desta relação, podemos destacar: Paulo Freire (2015, 2016); José Carlos Libâneo (2004, 2011) e Maurice Tardif (2014). No que diz respeito ao uso de recursos didáticos na área da Geografia, destacamos: Lana Cavalcanti (2002, 2006, 2008); Helena Copetti Callai (2000, 2003, 2011); Flaviana Calado (2010) e José Vesentini (2006).

Na primeira parte deste artigo registramos e analisamos as discussões realizadas a respeito das características do processo ensino, sobretudo, a partir dos saberes desenvolvidos pelo professor ao longo de sua formação e exercício profissional. 
Em seguida, reforçamos o papel desempenhado pelo professor como estimulador do interesse dos alunos para com os conhecimentos escolares por meio da compreensão do potencial da utilização de recursos didáticos. Pretendemos com esse trabalho trazer algumas contribuições, mesmo que liminares, para o ensino da Geografia, fazendo uma análise bibliográfica do processo de ensino e aprendizagem e da utilização de diferentes recursos didáticos.

\section{PROCESSO DE ENSINO E FORMAÇÃO DOCENTE}

Iniciamos nossa pesquisa verificando nas obras consultadas que o trabalho docente constantemente nos traz desafios, principalmente quando tratamos de situações que vivemos na educação nos dias atuais (VESENTINI, 2006). Falta de investimentos nas escolas, falta de materiais didáticos, grades curriculares que não condizem com as realidades sociais, precarização das condições de trabalho docente, enfim, vivenciamos o desmonte da educação pública. Todo este contexto traz preocupações alarmantes quanto o futuro da educação no Brasil, entretanto, reputamos que tais situações apesar de dificultar, sobremaneira, o sucesso da prática educativa, não o impossibilita (VLACH, 2014). Isso porque, partimos do pressuposto que um componente importante desta equação está no trabalho docente, na compreensão de seu papel social como professor. Ele que, sendo mediador do processo de ensino e aprendizagem, é um agente social que possibilita a transformação (CAVALCANTI, 2002; 2006).

Para que o processo educativo ocorra efetivamente faz-se necessário que os professores disponham de certos conhecimentos básicos em sua formação. Para tanto, a formação docente deve, na leitura de inúmeros autores, dentre os quais destacam-se Paulo Freire (2016), Maurice Tardif (2014) e Lana Cavalcanti (2006), garantir alguns saberes docentes básicos.

Começamos destacando Tardif (2014) na qual ressalta que os saberes docentes necessários para que o professor desenvolva um trabalho docente de qualidade estão divididos em quatro classificações: saberes da formação profissional; saberes disciplinares; saberes curriculares; saberes experienciais. 
Os saberes da formação docente são aqueles no qual são transmitidos aos professores, em sua formação inicial e continuada, durante o processo de formação, sendo conhecimentos pedagógicos relacionados às técnicas e métodos de ensino. Os disciplinares que são saberes reconhecidos e identificados como pertencentes aos diferentes campos do conhecimento, produzidos e acumulados pela sociedade ao longo da história, são administrados pela comunidade científica e o acesso a eles deve ser possibilitado por meio das instituições educacionais. Os curriculares que são saberes relacionados às formas que as instituições educacionais organizam os saberes produzidos dentro da sociedade que devem ser transmitidos aos alunos. $\mathrm{E}$ por fim, os saberes experienciais, que são os saberes resultantes pelo exercício da atividade profissional de docente, produzido por meio da vivencia cotidiana escolar com diferentes grupos (alunos, colegas, pais).

Para Tardif (2014) o professor desempenha papel central e, nesta perspectiva, o processo formativo do professor, embora fundamental, não é concluído durante seu processo acadêmico de preparação. Por isso, enfatiza a importância dos saberes experienciais que só podem resultar de sua vivência junto à comunidade escolar em que atua, visão compartilhada por Cavalcanti (2006).

Já Freire (2016), parte do pressuposto que o professor é mediador do conhecimento. No que tange ao arcabouço necessário ao exercício da profissão, traz consigo uma série de condições ou exigências necessárias à prática docente.

Em constante discussão, não somente por atuantes da área, mas para grande parte dos pesquisadores da educação, a profissão professor é inserida em inúmeras pluralidades quando trata-se das diferentes habilidades que encontra em seus alunos. Durante sua formação, o professor tem acesso, sobretudo teoricamente, à muitas formas de compartilhar o conhecimento junto aos alunos. E como sabemos, os saberes do professor não são apreendidos e internalizados em um tempo predeterminado, mas sim através de um longo processo durante a formação inicial nas instituições de Ensino Superior. Segundo Tardif (2014), os saberes docentes são construídos progressivamente ao longo da sua vida familiar, escolar, acadêmica e profissional, por meio da experimentação de novos procedimentos, de novas técnicas desenvolvidas, experiências vividas e compartilhadas no ambiente de trabalho e reflexões acerca 
da prática, portanto, os saberes são de natureza mutável, sujeitos constantemente a reformulações.

Freire (2016) divide os saberes da prática educativa em três dimensões: a referente à prática docente, da atuação profissional; a referente ao processo de ensinar, na qual destaca que ensinar não é transferir conhecimento; e dimensão vinculada à especificidade do ser humano, em que ensinar é uma especificidade da espécie humana. Ele salienta ainda em seus estudos que ensinar exige rigor metódico, exige pesquisa, respeito aos saberes dos alunos, exige criticidade estética e ética, aceitar o novo e rejeitar qualquer forma de discriminação. Para Freire (2016) ensinar exige o exemplo e o reconhecimento da identidade cultural.

Como o autor destaca, o conhecimento não é algo acabado e transferível mas é uma elaboração de conceitos e saberes que são vivenciados no dia a dia, na família, nas instituições, na sociedade e, principalmente, na escola. O professor participa dessa construção dos conceitos com seus alunos, na qual produzem o conhecimento. Segundo

Freire (2016, p. 25): "quem ensina aprende ao ensinar e quem aprende ensina ao aprender". Isso ratifica que os alunos são parte do processo de ensino e aprendizagem, não somente como meros ouvintes ou receptores de informações, mas sim, sujeitos ativos e participativos do processo. O professor precisa de acordo com Freire (2016), estar a todo momento comprometido com a causa que luta (educação), sendo um ser tolerante e humilde, alegre e esperançoso, que dialoga com seus alunos, escutando-os seus anseios e respeitando sua autonomia e seus conhecimentos. Estes últimos mesmo muitas vezes originados do senso comum, trazem consigo a realidade vivida pelos educandos e devem ser trabalhados com os saberes científicos. Freire (2016), defende a educação popular.

Cavalcanti (2006) além dos aspectos mencionados por Tardif e Freire, indica a importância da formação continuada vinculando o processo de pesquisa ao ensino escolar e promovendo a capacidade de análise interdisciplinar para que o professor seja alimentado de forma contínua, não apenas por sua experiência individual, como também dos processos de formação nos quais ocorram a integração interdisciplinar. Independente da concepção teórica e metodológica em que se insira o profes- 
sor, os autores ratificam a concepção de que ensinar é estar ciente de que a educação possibilita mudanças e é uma forma de intervenção no mundo.

Em seguida destacaremos o uso dos recursos didáticos no ensino da Geografia como forma de buscar uma maior interação entre os alunos e os conteúdos trabalhados em sala de aula.

\section{RECURSOS DIDÁtICOS COMO INTERESSE DOS ALUNOS PELO CONTEÚDO ESCOLAR}

No contexto da educação brasileira, seria leviano a considerar que o professor é culpado pela falta de interesse dos alunos nos conteúdos ensinados. Vários motivos fazem com que o processo de ensino e aprendizagem de Geografia não ocorra. A partir das indicações de vários autores e, aqui destacamos Paulo Freire, é possível citar como motivadores do insucesso: a falta de planejamento, pesquisa e estudo do professor, de organização, sistematização e criticidade dos conteúdos e no caso da Geografia, falta de sentido aos assuntos que são abordados em sala de aula, tanto pelos alunos quanto pelos professores.

Como evidencia Freire (2016) ensinar não é transferir conceitos, fatos e saberes ou até mesmo "depositar" conhecimento na mente dos sujeitos, mas sim desafiar os discentes a produzir sua própria compreensão do que lhe está sendo comunicado, construindo os conceitos em conjunto com ambos, discentes e docentes, pois o nosso papel de educadores [...] "não é falar ao povo sobre a nossa visão de mundo, ou tentar impô-la a ele, mas dialogar com ele sobre a sua e a nossa" (FREIRE, 2015, p. 120).

É de suma importância que o professor veja o ser humano como algo inacabado, como consequência, a própria educação, sendo um processo que se inicia ao nascer da vida e tem seu fim ao término dela, a ser construído no dia a dia durante toda a vida.

O docente necessita que sua linguagem esteja em sintonia com a realidade vivida por seus alunos, para não se perder em meio a dissertações sobre conteúdos abstratos, fazendo com que os alunos não estejam interessados nos conteúdos trabalhados em sala de aula. 
Freire (2015) acentua a desmotivação dos educandos pela busca do conhecimento e pela descrença no papel da escola. Para que a aula se torne um momento atrativo para os educandos é de suma importância que o docente disponha de práticas educativas que condigam com a realidade social dos sujeitos com os quais trabalha.

Libâneo (1994, p. 111) pondera a respeito da centralidade das ações e práticas pedagógicas na elaboração de estímulos e motivação dos discentes para o aprendizado.

Para ele, isso se trata de uma via de mão direta, pois: "a motivação influi na aprendizagem e a aprendizagem influi na motivação". Para isso, diferentes recursos didáticos são ferramentas importantes no ensino de Geografia, pois com elas, possibilita-se atender à maior número de habilidades dos alunos dentro da sala de aula.

Callai (2002, p. 256) todavia, nos previne quanto ao risco de atribuirmos excessivo valor ao papel dos métodos e das técnicas de ensino, em detrimento dos conteúdos importantes para o desenvolvimento da boa prática docente, cuja ação corre o risco de tornar-se uma "capa metodológica sem conteúdo"

Enquanto mediador do aprendizado e é seu papel esforçar-se para criar mecanismos que favoreçam a ocorrência desse processo. Parecer corroborado por Libâneo (2011, p. 61) ao asseverar: "um dos mediadores responsáveis nesse desenvolvimento é o professor: descobrir mecanismos, metodologias e procedimentos sistemáticos do aprender a pensar".

Espera-se que o professor esteja adequado à realidade da escola e do local onde ela está inserida. Para isso, é necessário que ele desenvolva suas aulas com recursos que, de fato, façam com que o processo de ensino e aprendizagem ocorra efetivamente. Para que o professor não acabe por se tornar:

O intelectual memorizador, que lê horas a fio, domesticando-se ao texto, temeroso de arriscar-se, fala de suas leituras quase como se estivesse recitando-as de memória - não percebe, quando realmente existe, nenhuma relação entre o que leu e o que vem acontecendo em seu país, na sua cidade, no seu bairro (FREIRE, 2016, p. 29). 
Como já destaca Vesentini (2006, p. 20) o "professor precisa adequar seus planejamentos e leituras, levando em consideração a realidade local desses alunos, além de incorporar estratégias de ensino".

Fazer com que o aluno se sinta parte do espaço e da sociedade, o torna um cidadão de fato, que participa ativamente dos atos políticos, na luta por seus direitos e da sociedade. Por isso o professor precisar elaborar suas aulas da melhor forma possível, para que o processo de ensino e aprendizagem ocorra efetivamente.

\section{RECURSOS DIDÁTICOS NO ENSINO DE GEOGRAFIA}

Os recursos didáticos se inserem no arcabouço de possibilidades dos saberes profissionais, e são ferramentas que podem ser descobertas, aprimoradas e realocadas de acordo com diferentes situações e realidades, sendo que o modo ideal de sua utilização dependerá da concepção metodológica do professor. É fundamental explicitar que muitos recursos didáticos estão disponíveis, porém não necessariamente acessíveis, e conhecendo a realidade educacional brasileira, a utilização de diferentes recursos está ligada as condições propicias ou não ao seu uso no contexto da realidade escolar.

Muitas escolas não possuem grandes aparatos de recursos didáticos para serem utilizados nas aulas pois, na maioria das vezes, os recursos financeiros são escassos tornando dificultosa a adesão a tecnologias, à mapas temáticos e a outros recursos em geral.

Segundo a autora:

Observa-se, no entanto, que há escolas, que em pleno século $\mathrm{XXI}$, que não possuem esse aparato de recursos metodológicos e, muitas vezes, nem o recurso mais simples como quadro branco e livros didáticos, observando-se ainda no seu acervo bibliográfico, uma grande insuficiência de livros (CALADO, 2012, p. 16).

Os recursos didáticos auxiliam o professor no sentido de serem ferramentas que propiciam uma maior dinamicidade das aulas de Geografia, tornando-as mais atrativas tanto para os alunos quanto para os professores, sendo ferramentas que possibilitam uma maior aproximação entre os saberes científicos e os saberes do senso comum, tornando os conteúdos mais próximos à realidade social dos alunos. 
Ao investigar como os recursos didáticos são tematizados no campo do ensino de Geografia verificamos que há uma ampla possibilidade dos professores utilizarem recursos específicos nas aulas, tais como o globo terrestre, os mapas temáticos, a bússola, as maquetes, os fantoches, os filmes e/ou documentários, as fotografias, as amostras/coleções de rochas e solos, os jogos e softwares educativos, entre tantas outras possibilidades que poderíamos citar (BRANDÃO \& MELLO, 2013, p. 15).

Nesse contexto Cavalcanti destaca a importância de incorporamos outras formas de linguagens para que "sejam propiciadores da manifestação dos sujeitos, de sua diversidade e do processo de significação dos conteúdos, incluindo a música, a literatura, o cinema, a cartografia, o estudo do meio, os jogos de simulação" (CAVALCANTI, 2008, p. 33).

Quando utilizamos de diferentes recursos didáticos na Geografia, conseguimos, na maioria das vezes, atender as diferentes habilidades cognitivas dos alunos, pois na sala de aula há sujeitos heterogêneos que dispõem de habilidades distintas e para quem se faz necessário encontrar mecanismos de acesso - alcance para que o processo de ensino e a aprendizagem ocorra. Há alunos com melhores desenvoltura visual (com filmes, documentários e imagens), na escrita (textos, resenhas, poesias, análises interpretativas), na audição (com a música e sons), outros por meio de expressões corporais e artísticas (com teatro, charges, etc.).

Dentre os recursos didáticos, podemos citar o filme como um recurso muito utilizado nas aulas de Geografia, uma vez que possibilita atender algumas dessas habilidades:

[...] o papel do filme na sala de aula é o de provocar uma situação de aprendizagem para alunos e professores. A imagem cinematográfica precisa estar a serviço da investigação e da crítica a respeito da sociedade em que vivemos. Trata-se, portanto, de um movimento de apropriação cognitiva da relação espaço-imagem e principalmente, da criação de sujeitos produtores de conhecimento e reconhecimento de si mesmos e do mundo. (BARBOSA, 2003, p. 113)

Outro recurso didático utilizado são os jogos por se tratar de um perfil de atividade bem aceito desde os Anos Iniciais aos Anos Finais da Educação Básica. Os autores descrevem positivamente as experiências neste sentido, mas alertam para a 
necessidade de compreensão e clareza por parte do professor para conduzir a atividade de forma a atingir seus objetivos.

Ao propor uma atividade lúdica, o professor deve deixar claro para os educandos, antes de dar início a qualquer tipo de jogo, qual é o seu objetivo. Além disso, o educador deve deixar evidente qual é o objetivo a ser alcançado no final da atividade. Assim ficará mais fácil para o professor ter o controle da turma e acompanhar o desenvolvimento da atividade (SANTOS \& BELMINO, 2016, p. 132).

Ainda outro recurso didático de grande proveito, principalmente na área da Geografia é o trabalho de campo. Apesar de gerar trabalho do ponto de vista da logística de retirar as turmas das dependências da escola, este recurso se configura didaticamente como profícuo por possibilitar trabalhar de forma integrada elementos sócio espaciais (relevo, hidrografia, urbanização, industrialização, problemas ambientais, econômicos, culturais, etc.).

Vale ressaltar que os recursos didáticos, por si só não são suficientes para que o processo de ensino e aprendizagem ocorra, necessita-se de metodologias de ensino e planejamentos com objetivos claros que acompanhem os recursos para que, de fato, o processo ocorra de forma positiva.

Consideramos ser importante que o professor tenha consciência dos saberes necessários à sua profissão, saberes estes construídos tanto na vida acadêmica de formação profissional como no dia a dia do trabalho docente, na vivência social da sua cidade, do seu bairro e das instituições que participa, para que possa, desenvolver práticas educativas críticas e reflexivas, no que se está sendo trabalhado, fazendo com que haja a construção do conhecimento em conjunto com alunos e professores.

Não adianta dispor de recursos didáticos, sendo que o professor, como destaca Freire (2016) possui métodos tradicionais de ensino, não é reflexivo, não possui rigor metódico no seu trabalho, não planeja e não dialoga com seus alunos.

É considerável a importância do professor no processo já que ele é o elo entre o conteúdo e a aprendizagem, com o auxílio dos recursos didáticos é possibilitado a aproximação dos conteúdos com as realidades sociais. 


\section{CONSIDERAÇÕES FINAIS}

Percebe-se que uma das dificuldades dos professores nos dias atuais está na falta de motivação dos alunos. Muitos deles desinteressados e professores com conteúdos preparados de forma "engessada", que não possuem sentido algum para os alunos e, muitas vezes, nem para os professores. São conteúdos que não condizem com a realidade concreta dos alunos, é algo totalmente abstrato.

Por isso é relevante discutirmos o papel que os recursos metodológicos desempenham no processo de ensino e aprendizagem, bem como, o da utilização de diferentes recursos didáticos no ensino da Geografia.

Se faz necessário que todo educador tenha consciência de sua importância frente a sociedade e diante da produção do conhecimento, ele é o mediador do processo de ensino e aprendizagem e é necessário que suas aulas sejam planejadas e desenvolvidas conforme a realidade de seus alunos, para que os conteúdos trabalhados tenham sentido para a vida dos mesmos. Para tanto, acreditamos que os recursos didáticos facilitem o desenvolvimento do processo de ensino da Geografia.

Os recursos didáticos são importantes já que, para que o processo de ensino e aprendizagem ocorra, se faz necessário atingir as diferentes habilidades de nossos alunos, pois possuímos alunos com várias dificuldades de aprendizagem e alunos com habilidades múltiplas, alunos bons em aprender com jogos, alunos melhores na escrita, na música, no teatro e ainda outros no áudio visual.

Constatamos que os recursos didáticos são importantes para o ensino e aprendizagem pelo fato de conseguirem atingir as diferentes habilidades dos alunos, mas vale ressaltar que os recursos necessitam estar acompanhados por práticas educativas que condizem com as realidades sociais, já que os recursos por si só não são suficientes.

Verificamos que os recursos didáticos trazem uma maior interação entre professores e alunos, além de trazerem maior interesse dos alunos na busca pelo conhecimento, pois oferecem mais dinamismo às aulas e aos conteúdos e às tornam mais atrativas, rompendo com a ideia de que o professor é o único detentor do conhecimento e os alunos apenas meros receptores de informações. 
A formação acadêmica, a compreensão do papel social e o contínuo exercício de atualização com a realidade dos alunos e as pesquisas científicas são fundamentais para que o professor tenha discernimento e utilize da melhor forma os diferentes recursos didáticos que cumprem também importante papel no processo de ensino e de aprendizado de Geografia.

\section{REFERÊNCIAS}

ANJOS, Josenilson Vieira dos. O computador como instrumento didático-pedagógico. In: Revista mundo Jovem. ed. Março de 2008. https://w w w .mundojovem.com.br/acao/feed-rss/gerar-rss

BARBOSA, Jorge Luiz. Geografia e Cinema: em busca de aproximações e do inesperado. In: CARLOS, Ana Fani A. et al. A Geografia na Sala de Aula. São Paulo: Contexto, 2003.

CALADO, Flaviana Moreira. O Ensino de Geografia e o Uso dos Recursos Didáticos e Tecnológicos. In: Geo saberes. v. 3, n. 5, 2010. Fortaleza: Universidade Federal do Ceará. p.12-20.

CALLAI, Helena Copetti. O conhecimento geográfico e a formação do professor de geografia. In: Revista Geográfica de América Central, vol. 2, 2011, p. 1-20.

. Estudar o lugar para compreender o mundo. In: CASTROGIOVANNI, Antonio Carlos (Org.). Ensino de Geografia: práticas e textualizações no cotidiano. Porto Alegre /RS, Editor Mediações, 2000.

. O ensino de Geografia: recortes espaciais para análise. In: CASTROGIOVANNI, Antonio Carlos (Org.) et al. Geografia em sala de aula: práticas e reflexões. Porto Alegre /RS, Ed. UFRGS/Associação dos Geógrafos Brasileiros, 2003.

CARVALHO, Breylla Campos. SANTOS, André Henrique Bezerra dos. OLIVEIRA Déborah de. Trabalho de campo como recurso didático no ensino de geografia física. In: Educadores, 2013.

CAVALCANTI, Lana de Sousa. Geografia e práticas de ensino. Goiânia: Alternativa, 2002.

. Geografia, escola e construção de conhecimentos. Campinas: Papirus, 2006. - (Coleção Magistério: Formação e Trabalho Pedagógico. 
A Geografia escolar e a cidade: ensaios sobre o ensino de Geografia para a vida urbana cotidiana. Campinas- SP: Papirus, 2008.

FREIRE, Paulo. Pedagogia da Autonomia: saberes necessários à prática educativa. 54 ed. Rio de Janeiro: Paz e Terra, 2016.

. Pedagogia do Oprimido. 59 ed. Rio de Janeiro: Paz e Terra, 2015.

LIBÂNEO, José Carlos. A didática e a aprendizagem do pensar e do aprender: a teoria histórico-cultural da atividade e a contribuição de Vasili Davydov. In: Revista Brasileira de Educação. Rio de Janeiro, v. 27, n.27, p. 5-24, 2004.

Adeus Professor, Adeus Professora? Novas exigências educacionais e profissão docente. 13. ed. São Paulo: Cortez, 2011.

MELLO, Márcia Cristina de Oliveira; BRANDÃO, Inêz de Deus Neiva. Recursos Didáticos no Ensino de Geografia: Tematizações e Possibilidades de Uso nas Práticas Pedagógicas. São Paulo: UNESP, 2013.

MORIN, Edgard. E Le Moigne, J. L. A inteligência da complexidade. Peirópolis, São Paulo, 2000.

SANTOS, Ovídia Kaliandra Costa; BELMINO, José Franscidavid Barbosa. Recursos didáticos: uma melhoria na qualidade da aprendizagem. In: Revista FIPED. Paraíba, 2016.

SOUSA, Cristiane Aureliano; MEDEIROS, Monalisa Cristina Silva; SILVA, José AdaiIton Lima; CABRAL, Laise Nascimento. A aula de campo como instrumento facilitador da aprendizagem em geografia no ensino fundamental. In: Revista educação pública. CEDERJ, 2016.

TARDIF, Maurice. Saberes Docentes e Formação Profissional. 17. Ed. Petrópolis - RJ: Vozes, 2014.

VESENTINI, José William. Educação e ensino da geografia: instrumentos de dominação e/ou de libertação. In: CARLOS, A. F. A. (Org.) A Geografia na sala de aula. 8. ed. São Paulo: Contexto, 2006.

VLACH, Vânia Rubia Farias. O ensino da Geografia no Brasil: uma perspectiva histórica. In: VESENTINI, José William. Ensino de geografia no início do século XXI: desafios e perspectivas. Instituto de Geografia, UFU, Uberlândia: Papirus, 2014. 


\title{
GEOGRAFLA, ESPORTE E EDUCAÇO: NOVAS PRÁTICAS DE ENSINO A PARTIR DO FUTEBOL
}

\author{
FERNANDA SERAFIM ALVES \\ GILVAN CHARLES GERQUEIRA DE ARAU゚JO
}

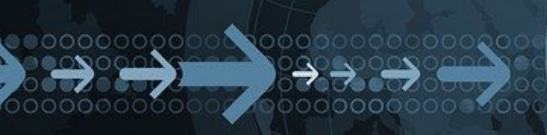
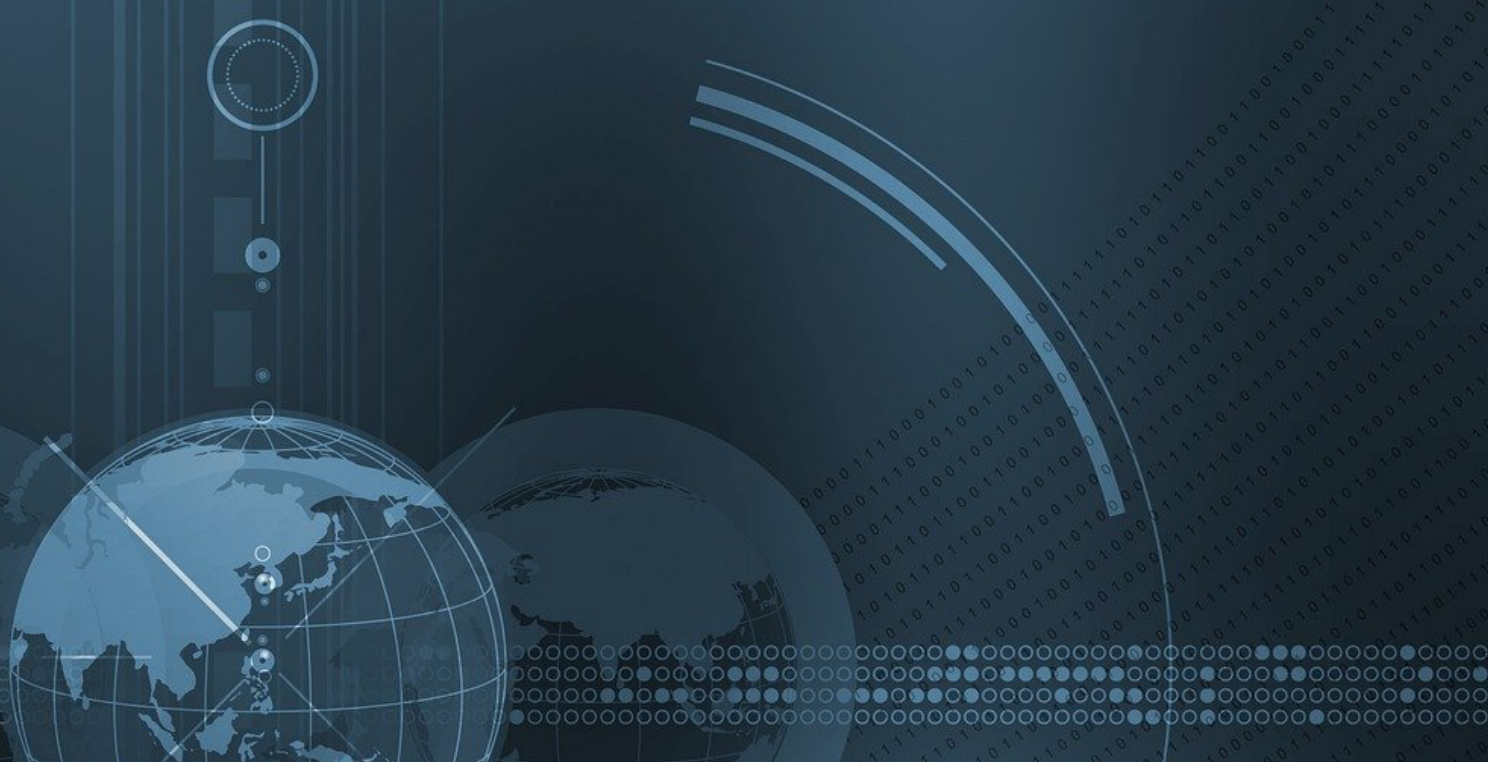

1 Graduada em Geografia pela Universidade de Brasília - UnB (2019), Mestranda em Geografia pela UnB. E-mail: fernandaserafimgea@gmail.com

2 Graduado em Geografia pela UNESP - Campus Rio Claro/SP (2009), Mestre em Geografia pela Universidade de Brasília (2013), Doutor em Geografia pela UNESP - Campus Rio Claro/SP (2016). Atualmente é professor de Geografia na Secretaria de Estado de Educação do Distrito Federal e realiza estágio de pós-doutoramento em Geografia pela Universidade de São Paulo. E-mail: gcca99@gmail.com ORCID ID: https://orcid.org/0000-0003-4238-0139 


\section{INTRODUÇÃO}

O futebol carrega elementos importantes, que podem ser trabalhados pelo professor de Geografia, como uma forma de exemplificação de uso e significado de diferentes categorias geográficas como paisagem, lugar, território, territorialidade, fronteira, região, dentre outros. É comum próximo de construções esportivas de um clube, objetos referentes a ele, sinalizando aos transeuntes que aquele local é território de um time, bem como a possibilidade de relacionar aspectos históricos, culturais e históricos às diferentes totalizações passíveis de serem analisadas geograficamente no âmbito do esporte e futebol.

$O$ agenciamento de tais categorias geográficas com a riqueza temática do futebol pelo olhar geográfico é o principal objetivo do presente capítulo. A um só tempo, é possível considerarmos os princípios do raciocínio geográfico, o ensino de Geografia na Educação Básica e, principalmente, a correlação direta entre o escopo teórico e metodológico da ciência geográfica com diferentes elementos, dimensões, fatores e vetores que fazem parte da análise do futebol pela Geografia.

A história do futebol no Brasil é antiga. O esporte que chegou ao País através de portos e ferrovias, teve no começo dos anos de 1900 seus primeiros times sendo fundados (MASCARENHAS, 2014). Desde então, campeonatos estaduais e nacionais enchem as arquibancadas dos estádios e estão no cotidiano dos brasileiros com a contribuição inclusive dos mais diversos meios de comunicação, sejam eles a televisão, rádio, internet ou jornais impressos. O futebol é tema frequente de conversas entre os estudantes ou mesmo atividade do dia-a-dia em momentos de lazer dos mesmos, contudo, o esporte que conquistou milhões de torcedores pelo país permanece distante ou mesmo esquecido pelas mais diversas disciplinas escolares, dentre elas, a geografia.

Recorrendo à história do esporte no Brasil, sabe-se que além dos portos e ferrovias, o futebol também foi bastante praticado nas escolas, sendo seu ensino e propagação feito por padres maristas, sobretudo no Rio Grande do Sul. Nos dias atuais, é interessante que o professor ao lecionar, entenda sobretudo as vivências do estudante, sendo o mesmo tratado primeiramente como um sujeito que possui predileções, dentre elas o futebol. Levar então um tema já tão debatido e por vezes 
praticado pelos discentes à sala de aula torna-se algo atrativo e inovador, fazendo com que a geografia seja vista pelo aluno como algo que faz parte também de seu cotidiano, sendo trabalhada em conjunto com o esporte que encontrou na escola uma maneira de ampliação.

O ensino de geografia se mostra tendo um campo de desafios, contudo repleto de possibilidades, onde teoria e prática devem dialogar. Para se obter sucesso, algumas estratégias podem e devem ser tomadas, dentre elas, a valorização do cotidiano do aluno e de seus saberes. Afinal, por ter como formação didático-pedagógica a ciência que estuda o espaço, o professor de geografia encontra nos assuntos abordados pela disciplina, inúmeros temas que privilegiam a vivência do estudante, dentre eles, o futebol, seja o esporte no auxílio para se trabalhar conceitos, ou mesmo temas.

Parte-se, portanto, do esporte, com maior atenção dada ao futebol, por meio do pensamento, metodologia e análise geográfica para assim chegarmos no ensino de Geografia, tendo como referência de ilustração didático-pedagógica as diferentes dimensões de exploração temática do futebol pela ciência geográfica.

\section{O ESPORTE DAS QUATRO LINHAS NO ENSINO DE LUGAR E PAISAGEM}

É possível que seja realizada a inserção da temática do futebol no arcabouço teórico e metodológico da Geografia e seu ensino. Como exercício de amostragem dessa abertura conceitual, cultural, epistemológica e didático-pedagógica façamos a exploração analítico-metodológica a partir de duas categorias geográficas: o lugar e a paisagem. Nesses termos, é cabível conceituar paisagem como tudo aquilo que conseguimos observar, sendo elas naturais ou culturais (as também chamadas paisagens artificiais).

A paisagem é uma das principais categorias geográficas, relacionada à dimensão imagética da totalidade da realidade objetiva, como recorte projetivo do mundo em que vivemos. Podemos efetuar a análise da paisagem pelo ponto de vista mais estrutural-formativo, como sugerido por Sauer (2004), e mencionado por Claval (2014), mas é imprescindível buscarmos um aprofundamento maior para a compreensão da paisagem em roupagens reificadas de sua potência teórica e epistemológica tanto 
para a Geografia atual como para a temática do futebol.

Desse modo, há uma renovação no entendimento geográfico sobre a paisagem, relacionando tanto sua base clássica e tradicional, atrelada aos aspectos descritivos da morfologia paisagística natural e social como, também, a ligação direta da paisagem como representação simbólica da tessitura cultural das diferentes sociedades que habitam o mundo, ou seja, pela paisagem chegamos às grafias da existência individual e coletiva do ser humano em sua relação com o meio: "Tal como se manifesta na experiência da paisagem, nossa relação sensível como mundo não é a de um sujeito posto em frente a um objeto, mas de um encontro e de uma interação permanente entre o dentro e o fora, o eu e o outro." (COLLOT, 2013, p. 26).

O mesmo autor ainda chama a atenção para que consigamos superar a premissa da paisagem como objetividade fechada em si mesma, ou seja, para que sua complexidade de elementos alcance o sujeito que nela habita, significando-a e fazendo com que todos os elementos paisagísticos adquiram camadas de sentidos múltiplos: "Essa troca entre o interior e o exterior não diz respeito apenas à percepção individual, mas também à relação que as sociedades humanas mantêm com seu ambiente." (COLLOT, 2013, p. 27). A renovação da paisagem como categoria geográfica proposta por Collot (2013) também pode ser encontrada em obras de autores como Cauquelin (2007) que trata sobre a invenção e substância da composição paisagística e Berque (1998) e Besse (2006) que retomam a base francófona da ideia de paisagem, amplamente servida como referência primária para a Geografia brasileira.

Já dentro da construção esportiva, há a categoria de lugar, também uma das bases conceituais-epistêmicas de maior presença e impacto na história do pensamento geográfico, muitas vezes superando divisões entre representantes das vertentes crítica ou cultural-humanística. O lugar possui o histórico pré-Geografia Cultura de foco na localização, no cruzamento de dados para determinação precisa de onde tal ou qual fato ou objeto geográfico se encontra (GOMES, 1996). A renovação do lugar na Geografia ocorreu seguindo principalmente o caminho crítico-dialético e, com maior diversidade e profundidade de exploração conceitual, a corrente cultural-humanística do pensamento geográfico.

Nesse sentido, o lugar pode ser entendido como espaço do nosso cotidiano, mas sobretudo nos remete a ideia de afeto. Surgem então os conceitos de Topofilia e 
Topofobia, do geógrafo Yi Fu Tuan (1980). Lugar se mostra como uma das categorias mais desafiadoras para se expor aos discentes por envolver a ideia de afeto, sendo necessário valorizar as experiências individuais dos estudantes para que a ideia de lugar seja melhor compreendida.

Destaca-se, também, que assim como ocorrido com a paisagem, o lugar passou por uma grande revisitação, ampliação e aprofundamento de sua tessitura epistêmica na Geografia contemporânea, superando algumas das divisões temáticas das diferentes correntes dessa ciência, como trabalhado por Marandola (2020) em continuidade a estudos efetuados outrora por Malpas (1999), Pickels (1985) e Buttimer (1985). Tais proposições de renovação do lugar pela significação, expressão simbólica, dimensões da existência e referencial da cultural no espaço geográfico podem ser encontrados em dialogia com posições de geógrafos como Casey $(1993 ; 1998)$, Massey (2008) e Moreira (2004).

A inserção da perspectiva materialista e histórica, pela crítica ao papel de transformação da lógica capitalista fará parte da renovação ontológica e epistemológica do lugar na Geografia. Se pensarmos em tal renovação na perspectiva do futebol, encontramos ligações diretas com a inserção do mercado futebolístico na relação dialética local-global, a partir de referenciais, elementos e dimensões comerciais, simbólicos, de consumo, representação, identitários, culturais e de diferentes perspectivas da temática do futebol analisado pelas categorias geográficas no cenário socioespacial contemporâneo.

Portanto, conceitos de paisagem e lugar, podem ser inclusive trabalhados em conjunto. Para Furlanetto "A paisagem reflete a dimensão simbólica das construções socioespaciais, a forma como o homem se relaciona com seu meio e o sentido a ele atribuído" (FURLANETTO, 2017, p. 18). É na paisagem encontrada dentro de um estádio de futebol que se percebe que o local vai além de uma mera construção onde se acontece uma partida de futebol. Nele se encontram diversos simbolismos que afirmam a identidade de um grupo, ligados pelo amor a um clube. Sendo ali uma paisagem, contudo para muitos, também seu lugar de afeto.

Os estádios, no caso do futebol, representam, a um só tempo, tanto um lugar como uma das grafias da composição paisagística das cidades. Holgado (2013) ressalta que o estádio de futebol é uma marca fixa na paisagem, elemento de destacada 
presença que se diferencia das paisagens e que representa um importante elemento cultural, reafirmando ser possível utilizá-lo nas aulas de Geografia para explicar conteúdos da mesma por meio da valoração simbólica da espacialidade, como o ocorre no caso da paisagem:

Os valores simbólicos inscritos na paisagem podem envolver tanto as pessoas que frequentam esses locais, quanto as pessoas que não têm acesso a eles. Isso demonstra como simbolismos podem ser levados para diferentes locais e, mesmo assim, manter-se em evidência. Esses simbolismos, abrem espaço para discutir as normas culturais que estão presentes nas paisagens, como por exemplo, ir ao jogo de futebol com a camisa do clube. Essas questões evidenciam a importância de discutir com os alunos as relações que podem ser estabelecidas entre as pessoas e os diferentes espaços. (HOLGADO, 2013, p. 106)

Além dos conceitos da Geografia aqui citados que podem ser associados ao futebol dentro de sala de aula, aspectos da cidade também podem ser estudados através do esporte. É o caso das mudanças no espaço geográfico, potencializados pela transversalidade incisiva de processos de transformações concreta e abstrata promovidas por fatores econômicos, culturais, históricos etc.

Ao retornarmos ao futebol e um dos seus principais objetos geográficos, o estádio, observamos potencialidades analíticas pela base epistemológica da Geografia. A abertura de aprofundamento e relação entre contradições, perscrutação pelas diferentes camadas de significação, fronteiras urbanas ou territoriais de alcance ou abrangência regional o local de torcidas para determinadas agremiações, os elementos históricos ou culturais de alteração ou permanência etc. De tantos quantos forem possíveis os caminhos a serem trilhados, fica a certeza de que, sim, há o encontro rico e profundo entre a teoria e metodologia geográficas com o campo de estudos voltados ao futebol.

\section{FUTEBOL EM SALA DE AULA: AS NOVAS POSSIBILIDADES DE ENSINO}

É comum se dar como significado de Geografia a descrição da Terra, sendo então a ciência que estuda o espaço e os elementos que nele estão, mas há uma gama considerável de profundidade e aberturas teórico-metodológicas, para a ciência geográfica, como demonstrado, brevemente, nas reflexões anteriores. Nas 
aulas iniciais da disciplina, é hábito frequente do docente a explicação dos conceitos fundamentais da ciência geográfica, sendo eles: espaço, território, região, lugar e paisagem. Não se pode negar a complexidade do trabalho do professor ao se abordar estes principais conceitos e demais temas da área, no entanto, o profissional deve procurar bons métodos para que o entendimento do conteúdo seja alcançado e os discentes alcancem a aprendizagem.

O professor nesse sentido pode questionar aos alunos quais mudanças eles notaram na cidade após a construção do estádio, ou mesmo usar como exemplo a Copa de 2014, sediada no Brasil, onde inúmeras melhorias ao redor do estádio foram feitas, enquanto outras regiões marginalizadas permaneceram esquecidas. É interessante inclusive ao docente buscar apontamentos dos alunos os fazendo os mais diversos questionamentos, dentre eles: qual o perfil de escolha das cidades para sediar os jogos? Foram respeitadas nessas escolhas todas as regiões do Brasil de forma igualitária? Durante as construções das Arenas se foi visto algum problema em relação ao trânsito da cidade? Após suas inaugurações, quais modificações do espaço urbano foram encontradas?

Com base nas respostas dos alunos é possível que o professor trabalhe os mais diversos temas encontrados na geografia, sejam eles o processo de urbanização e segregação espacial, desafios encontrados pelos moradores das grandes cidades, circulação, ou mesmo a gentrificação, além de ser possível a realização de debates como o racismo ou mesmo a homofobia que se outrora, eram atos aceitos dentro de campo, nos dias de hoje, também estão sendo combatidos.

A partir de tais exemplificações do cotidiano de ensino e aprendizagem dos professores de Geografia podemos ir além, correlacionando-o à riqueza e proficuidade temática do futebol ao escopo teórico e metodológico da Geografia, tendo como objetivo principal os caminhos pelos quais o aprendizado poderá ser alcançado a partir de tais referenciais. Há diferentes estudos de ensino de Geografia que primam por uma organização da prática pedagógica dessa ciência, tendo como norteadoras questões como a leitura das grafias do mundo em suas complexidades, a formação de professores, a conceitualização e importância da epistemologia no cotidiano escolar e a busca por princípios lógicos que orientem a prática docente. 
No que se refere aos princípios lógicos do raciocínio geográfico, estes possuem uma historicidade longeva de aparição e desenvolvimento. Pelo fato da Geografia possuir diferentes correntes e periodicidades de produção dos seus postulados encontramos desde referências como a de La Blache, de 1914 até as mais recentes colocações de Moreira (2008), quando o autor diz que:

Os princípios lógicos são os princípios da localização, distribuição, extensão, distância, posição e escala, Os antigos compreendiam a importância preliminar e central desses princípios na formação da personalidade e do discurso da representação geográfica. [...] Perceber um fenômeno em sua dimensão geográfica é assim primeiramente localizar, distribuir, conectar, medir a distância, delimitar a extensão e verificar a escala de sua manifestação na paisagem. (MOREIRA, 2008, p. 116-117)

Pedagogicamente, os princípios lógicos da Geografia permitem que façamos a correlação teórico-conceitual e analítico-metodológica de suas categorias. Esse exercício de observação, interpretação e aplicação conceitual já amplamente trabalhado pelos professores em seu cotidiano escolar (PONTUSCKHA, et. al. 2007; CASTROGIOVANNI; COSTELLA, 2012). Os princípios lógicos da Geografia podem ser observados, por exemplo, nas orientações curriculares da atual BNCC:

\section{Quadro 1: Princípios do Raciocínio Geográfico}

\begin{tabular}{|c|l|}
\hline Princípio & \multicolumn{1}{c|}{ Descrição } \\
\hline Analogia & $\begin{array}{l}\text { Um fenômeno geográfico sempre é comparável a outros. A identificação } \\
\text { das semelhanças entre fenômenos geográficos é o início da compreensão } \\
\text { da unidade terrestre. }\end{array}$ \\
\hline Conexão & $\begin{array}{l}\text { Um fenômeno geográfico nunca acontece isoladamente, mas sempre em } \\
\text { interação com outros fenômenos próximos ou distantes. }\end{array}$ \\
\hline Diferenciação & $\begin{array}{l}\text { É a variação dos fenômenos de interesse da geografia pela superfície } \\
\text { terrestre (por exemplo, o clima), resultando na diferença entre áreas. }\end{array}$ \\
\hline Distribuição & Exprime como os objetos se repartem pelo espaço. \\
\hline Extensão & $\begin{array}{l}\text { Espaço finito e contínuo delimitado pela ocorrência do fenômeno geográ- } \\
\text { fico. }\end{array}$ \\
\hline Localização & $\begin{array}{l}\text { Posição particular de um objeto na superfície terrestre. A localização pode } \\
\text { ser absoluta (definida por um sistema de coordenadas geográficas) ou } \\
\text { relativa (expressa por meio de relações espaciais topológicas ou por inte- } \\
\text { rações espaciais). }\end{array}$ \\
\hline Ordem & $\begin{array}{l}\text { Ordem ou arranjo espacial é o princípio geográfico de maior complexi- } \\
\text { dade. Refere-se ao modo de estruturação do espaço de acordo com as } \\
\text { regras da própria sociedade que o produziu. }\end{array}$ \\
\hline
\end{tabular}

Fonte: BNCC (BRASIL, 2017, p. 358). 
Por meio de tais princípios é possível que leiamos o mundo, geograficamente, promovendo a busca pela utilização de diferentes princípios do raciocínio geográfico em sala de aula tendo como objetivo principal propiciar aos estudantes a leitura do mundo pela Geografia, utilizando tais princípios como norteadores desse processo (PEREZ, 2005).

Demais aspectos, e elementos da prática didático-pedagógica como materiais didáticos, metodologias de ensino, a formação de professores e as diferentes formas de avaliação farão parte desse processo de aprofundamento teórico-metodológico da Geografia, com vistas ao aperfeiçoamento do referencial epistemológico da prática docente na sala de aula, como destaca por Pontusckha et al. (2007, p. 123): “A formação de conceitos do ponto de vista lógico, por estruturação e organização, efetua-se por processos de constituição de classes (objetos que possuem os mesmos atributos; por exemplo, que apresentam a mesma forma, como triângulos, quadrados ou círculos) - mediante os atributos - e por hierarquização, que permite formar as redes de conceitos. (PONTUSCKHA, et. al. 2007, p. 123).

Como observado anteriormente, no caso das categorias de lugar e paisagem, somente será possível operacionalizarmo-las se pensarmos geograficamente a realidade do mundo que vivemos de forma dinâmica e complexa. Mesmo que não tenha sido efetuado o aprofundamento de outras possibilidades teórico-metodológicas a partir da ideia de territorialidade, território, região ou fronteira, em todos esses casos haverá sempre a importância e indissociabilidade com a totalização dos fatos geográficos analisados.

Ao considerarmos o ensino de Geografia, a partir dos princípios lógicos do raciocínio geográfico aplicado ao futebol teremos a disposição um rol espesso de camadas analíticas do recorte elegido para a análise geográfica em questão, como sugerido por Straforini (2002), quando afirma que:

A totalização seria a flecha do tempo e a ponta da flecha seria a totalidade. Se o corpo da flecha for entendido como uma reta (o que não significa linearidade), então, temos nele uma infinidade de pontos, isto é, realidades, ou ainda, totalidades de cada instante e/ou período. Cada ponto desses já foi, um dia, a ponta da flecha, isto é, a totalidade. Nesse sentido a totalidade A totalização seria a flecha do tempo e a ponta da flecha seria a totalidade. Se o corpo da 
flecha for entendido como uma reta (o que não significa linearidade), então, temos nele uma infinidade de pontos, isto é, realidades, ou ainda, totalidades de cada instante e/ou período. Cada ponto desses já foi, um dia, a ponta da flecha, isto é, a totalidade. Nesse sentido a totalidade sempre necessita dos pontos anteriores para incorporá-los e renová-los. Na verdade, cada totalidade dá as condições para a totalidade seguinte. Mas é possível abarcar a totalidade analiticamente na sua plenitude? É possível estudar o todo pelo todo? Ou ainda, a totalidade existe enquanto concretude de forma que não seja a ideia do planeta Terra? Mas a Terra apenas enquanto corpo físico não nos interessa, mas sim ela e mais aquilo que lhe preenche de vida e sentido: a sociedade. (STRAFORINI, 2002, p. 99-100)

Em um exercício de abstração didático-pedagógico do que fora comentado pelo autor, aplicado ao futebol em uma perspectiva geográfica, teríamos algumas possibilidades de ensino, aprendizagem e estudo 1) que a totalização do futebol dependerá de totalidades menores, formadas por recortes analíticos geograficamente determinados, como uma cidade, uma região, todo um país ou escalas internacionais; 2) independente da categoria geográfica em operacionalização epistêmico-conceitual ou didático-pedagógica pelos professores haverá a necessidade de inserção de sua delimitação espaço-temporal, sociocultural, político-econômica etc. ou seja, será preciso termos o recorte específico de observação geográfica para que consigamos extrair, ao máximo, a leitura desses fatos pelos princípios lógicos da Geografia, seja um estádio, torcidas, comércio movimentado pelos jogos, história dos clubes, dentre outras especificações temáticas possíveis de focalização.

\section{A BOLA ENTRA EM CAMPO: O ENSINO DE GEOGRAFIA NO CASO GRENAL}

Várias são as informações dadas a quem se desloca de que ele se encontra próximo de um estádio. Analisando o Grêmio Foot-Ball Porto Alegrense e o Sport Club Internacional, o domínio dos times próximo às suas respectivas construções esportivas é nítido: sejam pelas cores dos estabelecimentos - o bairro que abriga a Arena do Grêmio é inclusive conhecido como "o bairro azul"- figura 01., ou mesmo comerciantes formais e informais vendendo camisetas e demais objetos do time em dias de jogos, é possível notar ainda uma peregrinação existente. Como já dito, podendo ser entendido, a construção esportiva e seus arredores, como um verdadeiro 
território.

Levando tais informações para a sala de aula, o professor encontra um bom exemplo prático para se debater sobre território, já que por vezes é um conceito geográfico bastante abstrato para os estudantes, já que os mesmos tendem a associar território apenas pelo ponto de vista geopolítico, trazendo-o pouco para seu cotidiano. $O$ estudo dos estádios e seus arredores podem ir inclusive além, abrangendo novos temas como a urbanização, o capitalismo presente no comércio, além das mudanças ocorridas, na cidade, em dias de jogos, seja a partir da análise do fluxo dos transportes ou mesmo pela logística em relação à segurança dos transeuntes ao redor dos estádios.

[...] os estádios podem ser importantes elementos para a reorganização de uma área, atraindo para esses locais diversos investimentos. Essa discussão possibilita que os alunos realizem uma reflexão sobre processos que podem ocorrer no espaço urbano, percebendo os diversos interesses que podem estar presentes. (HOLGADO, 2013, p. 107)

Na figura abaixo, observa-se o bairro Humaitá que atualmente abriga a Arena do Grêmio. As cores ao redor da construção esportiva não por acaso são as mesmas do clube. Em busca de se ter o bairro azul, o time tricolor buscou pintar, com o consentimento dos moradores, as casas que ficam nos arredores da arena com as cores do time (azul, branco e preto), fator que colabora com a ideia do bairro ser portanto território do clube, aumentando a ideia de rivalidade com o colorado Internacional. Cabe ressaltar que se o bairro possui as cores do clube, dentro da Arena do Grêmio além das cores predominantes serem as do Grêmio, não se vê o vermelho, aumentando a percepção de rivalidade entre os dois maiores times de Porto Alegre. A ideia teve ainda como inspiração outro clube de futebol: o time argentino Boca Juniors. 
Figura 01 - Bairro Humaitá - o bairro azul

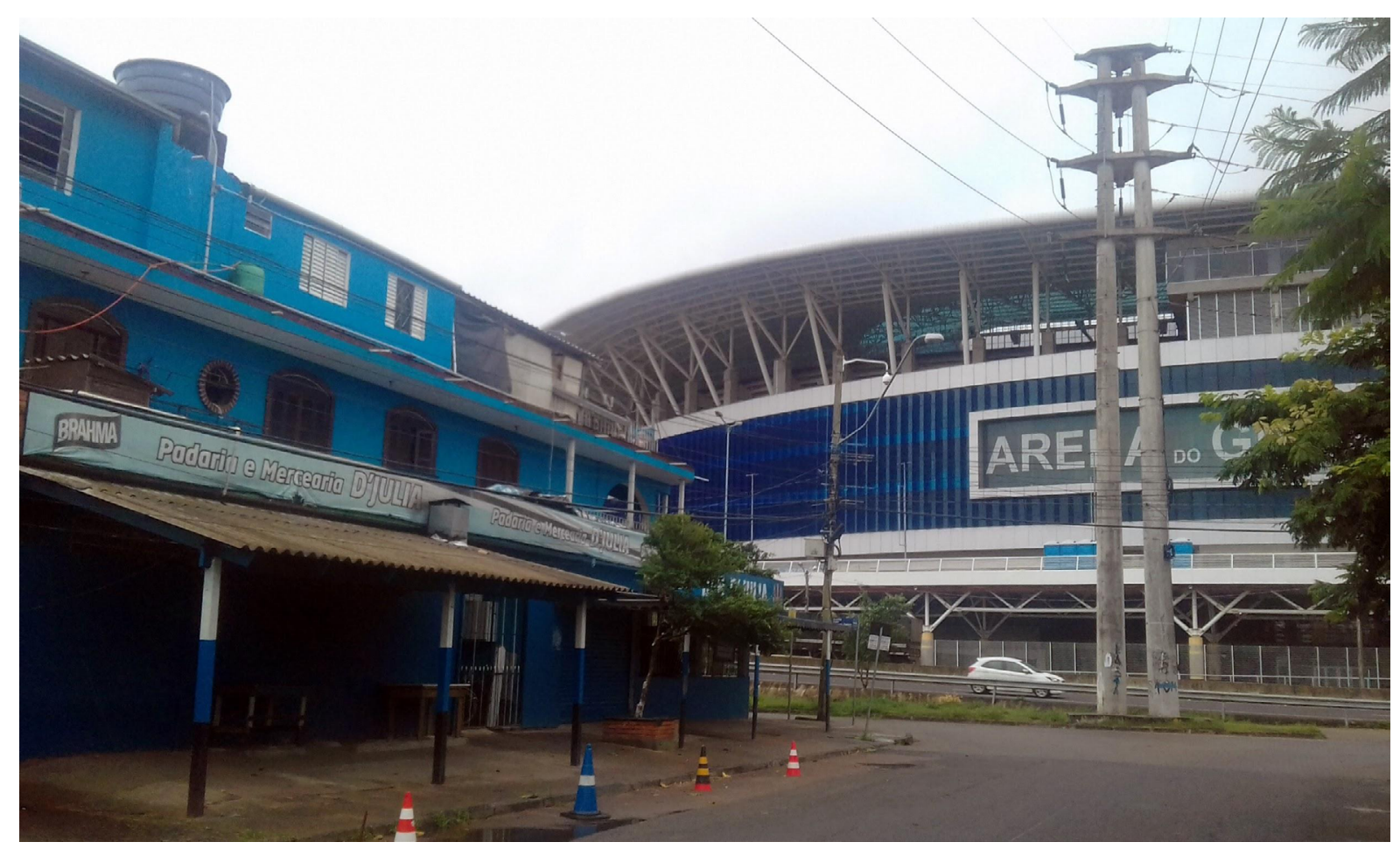

Foto: Autores - Porto Alegre, 25, fev. 2019.

Quando se trata de times rivais como, por exemplo, Vasco da Gama x Flamengo (Rio de Janeiro), Cruzeiro x Atlético Mineiro (Minas Gerais), Corinthians $x$ Palmeiras (São Paulo), Grêmio x Internacional (Rio Grande do Sul) ou mesmo Gama $x$ Brasiliense (Distrito Federal), os territórios considerados de um determinado time rejeitam, inclusive com certa violência, torcedores do clube rival.

As informações trabalhadas até o momento no texto, são por vezes, já conhecidas até mesmo pelos estudantes. É claro que sem os mesmos entenderem que se trata, por exemplo, de uma boa maneira de se compreender e aplicar o conceito de território. Se questionados, os alunos irão provavelmente citar alguma situação ou momento que viram ou mesmo vivenciaram a respeito da rivalidade existente entre os clubes de futebol. A partir destas vivências se percebe um momento propício ao docente para que as informações trazidas pelos alunos sejam abordadas em sala de aula através de um viés geográfico, sendo uma possibilidade de serem estudados os demais conceitos, além de outros temas abordados pela disciplina.

É no estádio onde se vivencia experiências individuais e coletivas, sendo por vezes um lugar também comum aos estudantes. Afinal, a depender da localização do discente no Brasil, há cidades com um ou mais estádios, como Porto Alegre, que pos- 
sui o Beira-Rio (estádio do Internacional) e a Arena do Grêmio (estádio do Grêmio). Desde 1904 a capital gaúcha possui estádios na cidade, informação interessante ao se pensar que é comum as crianças frequentarem as edificações esportivas desde muito cedo, pois tornou-se um hábito praticado por gerações (figura 02). Nos dias atuais Grêmio e Internacional possuem inclusive uma habilitação de sócio infantil.

Figura 02 - Criança em direção ao estádio Beira-Rio.

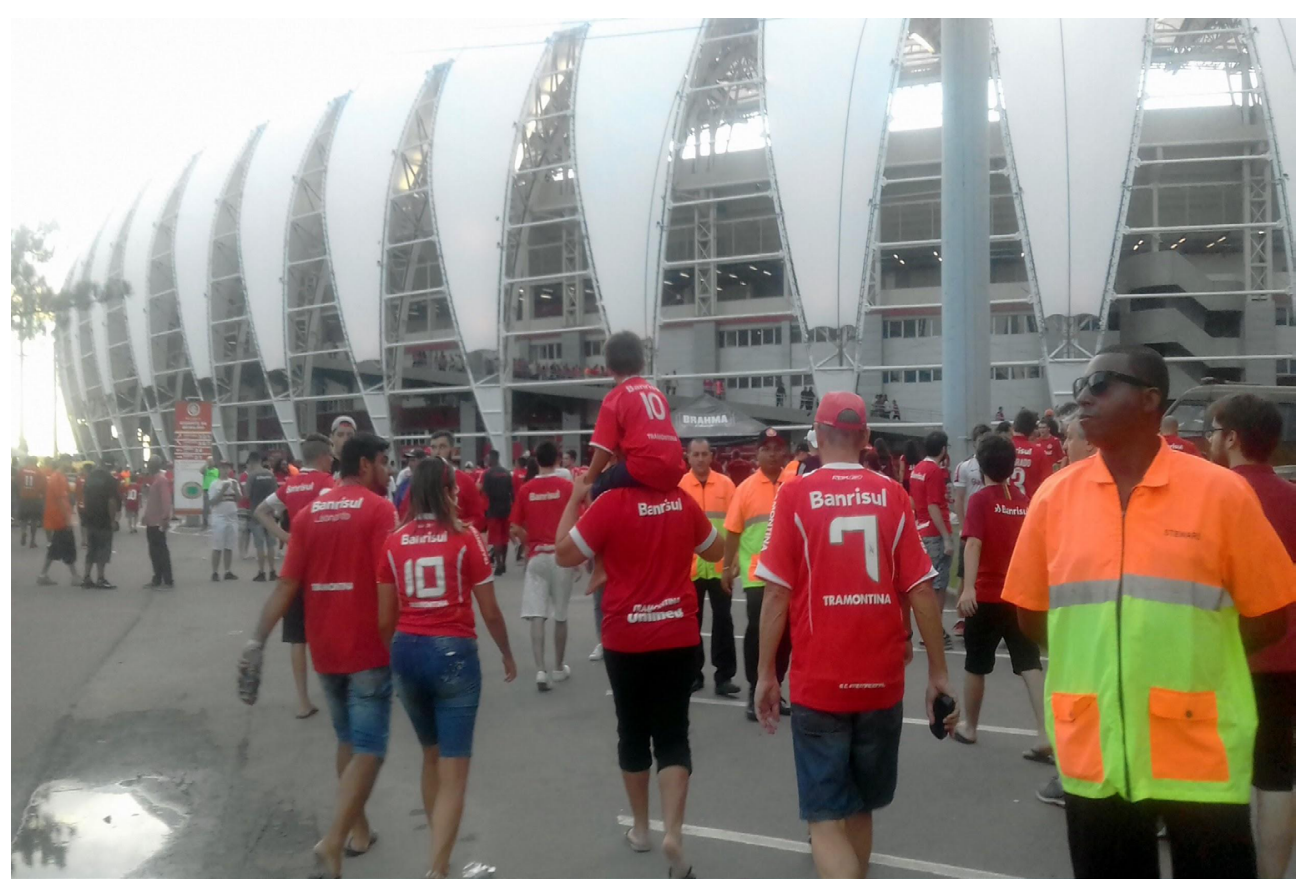

Foto: Autores - Porto Alegre, 17, fev. 2019.

Segundo Bandeira, "para uma criança nascida em Porto Alegre, antes de se pensar em estádios de futebol, é necessário se decidir qual dos dois estádios será frequentado: o do Grêmio ou o do Internacional" (BANDEIRA, 2009, p. 13). Decidido qual estádio, a ideia de lugar vai sendo construída aos poucos, em cada partida acompanhada dentro da construção esportiva, a cada gol visto e a cada competição que seu time venceu. Ou seja, a cada nova construção de afeto realizada entre a criança e outros sujeitos, ou mesmo a criança e o clube, dentro da edificação. Anos mais tarde e já adolescente, aquela ideia de lugar já se mostra bastante consolidada, a ponto inclusive, de qualquer mudança de estádio ser recebida com certo receio.

Pensando então na sala de aula e trazendo a geografia para a realidade do aluno valorizando seus saberes e suas vivências, explicar território a partir dos arredores dos estádios e da própria construção esportiva, surge como uma proposta interes- 
sante. As construções esportivas podem ainda ser usadas na explicação de Cultura ou mesmo de Lugar. Afinal, estádios podem ser considerados como geossímbolos, a partir da visão do geógrafo francês Joel Bonnemaison, quando define geossímbolo como: Um lugar, um itinerário, uma extensão, que, por razões religiosas, políticas ou culturais, aos olhos de certas pessoas e grupos étnicos, assume uma dimensão simbólica que os fortalece em sua identidade". (BONNEMAISON, 2012, p. 292).

Para Bonnemaison geossímbolos são costumeiramente usados na demarcação de um território, por exemplo, construções religiosas como igrejas e templos onde acontecem peregrinações, estátuas de uma figura política famosa para determinado grupo e no caso do futebol, como já dito: os estádios. É interessante analisar a ideia de geossímbolo e seu potencial em sala de aula, pois pode-se ainda trabalhar com os estudantes quais geossímbolos eles conhecem (dentro ou fora do esporte) e se algum deles é importante também para os mesmos como indivíduos que ao fazerem parte de uma sociedade, são membros também de grupos culturais, que ao utilizarem esses geossímbolos, fortalecem também suas identidades.

\section{CONSIDERAÇÕES FINAIS}

Como observado até aqui, o futebol se mostra uma ferramenta útil na explicação de fenômenos geográficos, sendo necessários maiores estudos sobre a utilização do esporte dentro de sala de aula. Respeitando a vivência dos alunos e suas experiências extraclasse, encontra-se no futebol um terreno fértil, pois o esporte demonstra ter aspectos semelhantes aos da sociedade em que vivem os discentes, fazendo com que os mesmos consigam associar teoria e prática e o docente promova então uma metodologia ativa de ensino.

Como exemplificado a partir dos clubes gaúchos Grêmio e Internacional, observa-se que trazer o futebol para as aulas de geografia vai muito além dos 90 minutos de uma partida. $O$ docente consegue abordar desde o que acontece dentro dos estádios (trabalhando a ideia de lugar, topofilia e topofobia, como já dito), até mesmo o conceito de território, quando se analisa os arredores destas construções, além das mudanças que ocorrem na paisagem e nas diversas dimensões do espaço urbano.

O estudo do futebol pela Geografia e o desafio de levar essa ponte teórica e 
analítica para a sala de aula foi o principal objetivo trabalhado no presente capítulo. A defesa pelo aprofundamento epistemológico na formação e prática de professores da Educação Básica deve ocorrer de forma perene, elencando desde o cotidiano escolar, passando pelo material didático até as vivências locais e singulares tanto dos professores como dos estudantes. Por meio do futebol tais dimensões do ensino de Geografia não apenas se tornam possíveis como abrem-se para dialogias outras, pontes temáticas e aplicações metodológicas diversificadas a partir do referencial epistêmico existente na Geografia.

\section{REFERÊNCIAS}

BANDEIRA, Gustavo Andrada. Eu canto, bebo e brigo... alegria do meu coração: currículo de masculinidades nos estádios de futebol. 2009. Dissertação (Mestrado em Educação) - Faculdade de Educação, Universidade Federal do Rio Grande do Sul, Porto Alegre.

BERQUE, Augustin. Paisagem-marca, paisagem-matriz: elementos da problemática para uma geografia cultural. In: CORREA, Roberto Lobato; ROSENDAHL, Zeny (orgs.). Paisagem, tempo e cultura. Rio de Janeiro: EdUERJ, 1998, p. 84-91.

BESSE, Jean-Marc. Ver a Terra: seis ensaios sobre paisagem e geografia. Tradução de Vladimir Bartalini. São Paulo: Perspectiva, 2006.

BONNEMAISON, J. Viagem em torno do território. In Geografia Cultural: Um século (3), org. R.L. Corrêa e Z. Rosendahl. Rio de Janeiro, EDUERJ, 2012.

BUTTIMER, Anne. Nature, water symbols, and the human quest for wholeness. In: SEAMON, David and MUGERAUER, Robert (eds.) Dwelling, place \& environment: towards a phenomenology of person and world. New York: Columbia University Press, 1985.

CAUQUELIN, Anne. A invenção da paisagem. Trad. Marcos Marciolino. São Paulo: Martins Fontes, 2007.

CASEY, Edward S. Getting back into place: toward a renewed understanding of the placeworld bstudies in continental thought). Indiana: Indiana University Press, 1993. 432p.

CASEY, Edward S. The Fate of Place: a Philosophical History. Berkeley: University of California Press, 1998. 
CASTROGIOVANNI, Antônio Carlos; COSTELLA, Roselane Zordan. Brincar e cartografar com diferentes mundos geográficos: a alfabetização espacial. $2^{\mathrm{a}}$ edição. Porto Alegre: EDIPUCRS, 2012.

CLAVAL, Paul. Epistemologia da Geografia. UFSC. Florianópolis. 2014.

COLLOT, Michel. Poética e filosofia da paisagem. Trad. Ida Alves. Editora: Oficina Raquel, 2013.

FURLANETTO, Beatriz Helena. Paisagem sonora do Boi de Mamão paranaense: uma geografia emocional. - Curitiba. Ed. UFPR, 2017.

GOMES, Paulo César da Costa. Geografia e modernidade. Rio de Janeiro: Bertrand Brasil, 1996.

HOLGADO, Flávio Lopes. Além das quatro linhas: o futebol no ensino de geografia. 2013. 123 f. dissertação (Mestrado em Geografia) - Programa de Pós-Graduação em Geografia, Instituto de Geociências - UFRGS. Porto Alegre, 2013.

LA BLACHE, Paul Vidal de. Sobre o raciocínio geográfico. Terra Brasilis. São Paulo, v. 12 , p. 1-7, 1914 [2019].

MASCARENHAS, Gilmar. Entradas e bandeiras: a conquista do Brasil pelo futebol. Rio de Janeiro: EdUERJ, 2014.

MALPAS, Jeff. Place and Experience. Cambridge: Cambridge University Press, 1999.

MARANDOLA JR., Eduardo. Lugar e lugaridade. Mercator, Fortaleza, v. 19, p. 1-12, 2020.

MASSEY, Doreen. Pelo espaço. Rio de Janeiro: Bertrand Brasil, 2008.

MOREIRA, Ruy. Marxismo e geografia: a geograficidade e o diálogo das ontologias. GEOgraphia, Niterói: PPGEO-UFF, Ano VI, n. 11, p.21-37, 2004.

MOREIRA, Ruy. Pensar e ser em geografia: ensaios de história, epistemologia e ontologia do espaço geográfico. São Paulo: Editora Contexto, 2008.

PÉREZ, Carmen Lúcia Vidal. Ler o espaço para Compreender o Mundo: a função alfabetizadora da geografia. In: Revista Tamoios (Impresso), v. 2, p. 17-24, 2005. 
PONTUSCKHA, N. N.; PAGANELLI, T. I.; CACETE, N. H. Para Ensinar e Aprender Geografia. São Paulo: Ed. Cortez, 2007.

SAUER, Carl. A morfologia da paisagem. In: Paisagem, Tempo e Cultura. [Org.] CORREAA, R. L. \& ROSENDAHL, Z. 2ª Ed. Rio de Janeiro: Editora UERJ, 2004.

STRAFORINI, Rafael. A totalidade Mundo nas primeiras séries do ensino fundamental: um desafio a ser enfrentado. In: Terra Livre, São Paulo, v. 1, n.18, p. 95-114, 2002.

TUAN, Yi-Fu. Topofilia: um estudo da percepção, atitudes e valores do meio ambiente. São Paulo: Difel, 1980. 


\section{A ESCOLA COMO ESPACO DE REGULACGAO DO ALUNADO: UMA ABORDAGEM TEÓRICA EM TORNO DO GENERO E PROPOSIÇOES DE AÇO}

GUSTAVO HENRIQUE CAMARGO EUFRÁSIO CARMEM LÜCIA COSTA
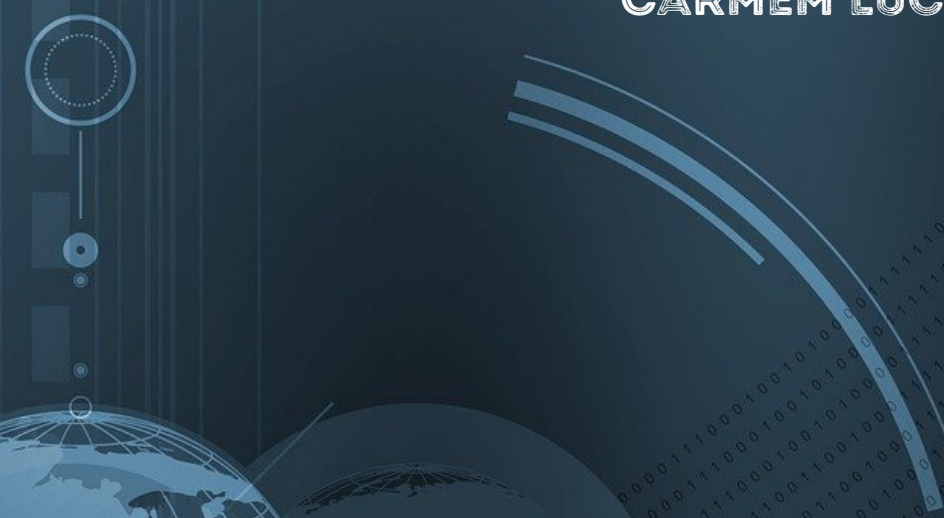

1 Graduando em Geografia (licếciatura) pela Universidade Federal de Goiás/Regional Catalão. Realiza iniciação científica através do PROLICEN 2020-2021, além de possuir outros dois plaenthos de trabalho concluídos (PROLICEN 2018-2019 ePIVIC 2019-2020) Ë membro do DIALOGUS/ UFCAT/CNPq - Estudos Interdisciplinares em Gênero, Cultura e Trabalho. . gustavocamargo_11@ outlook.com.

2 Graduada e mestre em Geografia pela Universidade Federal de Goiás com doutorado em Geografia Humana pela Universidade de São Paulo e pós-doutorado pela Universidade Federal de Juiz de Fora. É professora do curso de Geografia na Universidade Federal de Catalão, compõe o Programa de Pós-Graduação em Geografia da mesma instituição e do Programa de Pós-Graduação Interdisciplinar em Direitos Humanos na UFG/Goiânia. É membra do DIALOGUS/UFCAT/ CNPq - Estudos Interdisciplinares em Gênero, Cultura e Trabalho. clcgeo@gmail.com. 


\section{INTRODUÇÃo}

Alunos, alunas, professores, professoras são alguns dos tantos que são fundamentais para o funcionamento de uma escola, cuja função desta é ser o locus do conhecimento, da aprendizagem. Onde ler, escrever, contar e investigar são alguns dos verbos que devem ser admirados e praticados. Todavia, por intermédio de Junckes e Silva (2009) se enxerga uma escola marcada pela conservação de papéis sociais, fazendo surgir uma indagação: seria a escola um espaço de superação do patriarcado ou reprodução deste?

Como pontapé inicial nesta discussão, recorre-se a visão de Madureira (2007) sobre a escola:

a escola é um espaço atravessado pela contradição. Por um lado, abriga inúmeros preconceitos e reproduz constantemente processos de exclusão. Por outro, é um espaço que pode, sim, desestabilizar as 'regras do jogo', tornar as pessoas mais conscientes de si e do mundo em que estão inseridas. (MADUREIRA, 2007, p. 92, grifos do autor)

Incutir essa incessante reflexão sobre a escola impõe uma tarefa de contextualizar este trabalho com a sua importância teórica e metodológica. Portanto, se justifica sua importância por dois momentos: o primeiro se dá em 2016 com o sacramento do golpe político contra a presidenta Dilma Rousseff e o segundo é a vitória presidencialista de Jair Bolsonaro em 2018. Períodos em tempos diferentes que confirmam um cenário de instauração do conservadorismo e do neoliberalismo. As afirmações que são levantadas encaminham o desenvolvimento deste trabalho na busca por compreender a importância da Geografia no campo de estudo do gênero e da sexualidade, em especial, no ambiente escolar.

Pensar construir uma análise que primasse por uma comprovação de quão intencional o espaço escolar é e das consequências que este possui aos sujeitos são tarefas que demandam leituras e pesquisas que vão desde teóricas(os) no campo do ensino da ciência geográfica, dos estudos espaciais, de gênero e de questões educacionais. Para tal feito e buscando satisfatório resultado optou-se por realizar uma revisão bibliográfica recorrendo em Costa (2011), Louro (2000), Silva (2003) e Santos (1978). Pesquisas de campo em instituições escolares não foram cogitadas visto que o intuito central é um levantamento teórico em torno da funcionalidade da 
escola para regulação dos corpos e das identidades de gênero.

Os resultados esperados neste projeto são endereçados como forma de resistência à perversidade levantada pelo movimento conservador e anticientífico, Escola Sem Partido.

\section{RESULTADOS E DISCUSSÃO}

A realidade brasileira é vista como um período de intensas mudanças. Fazendo um recorte sobre o cenário político é perceptível a insurgência, comprovada nas eleições de 2018, da direita política, caracterizada por ser conservadora, moralista e dogmática. Este cenário de avanço aos preceitos fundamentalistas se dá devidamente ao processo histórico do golpe de 2016 e a desmoralização da democracia arduamente construída desde o período pós-ditadura militar.

Golpear a democracia é sinônimo de incentivar as perversidades que afligem o primar social, exemplos são explicitados através das medidas desenvolvidas durante os governos de Jair Bolsonaro e de Michel Temer, a seguir três medidas exemplificam $\mathrm{o}$ ataque à sociedade e $\mathrm{a}(\mathrm{o}) \mathrm{s}$ trabalhadoras(es): a emenda constitucional de congelamento dos gastos públicos por vinte anos; a reformulação da legislação trabalhista e da previdência social; no plano educativo - em especial - o movimento Escola Sem Partido.

Atacar o proletariado é reflexo da clássica perversidade que se apresenta como motor capitalista do lucro e das vantagens de benefício da burguesia (SANTOS, 2003). Muitas críticas podem ser tecidas as legislações contemporâneas brasileiras citadas acima, todavia, será convergido a análise sobre o movimento Escola Sem Partido. O intuito aqui não é explicar o movimento e seu desenvolvimento, mas o quão estratégico é este movimento quando se compreende o espaço escolar como um locus de regulação dos papéis sociais.

Recorrendo em clássicos entende-se que os espaços estão em constante (re)produção, constituídos por meio de relações apontadas por Milton Santos (1978) como consequências de uma produção histórica dos sujeitos sociais. Diante disso, as ações que configuram os espaços estão fundadas em intencionalidades e que estão relacionadas com as estruturas sociais. Portanto, quando se enxerga que a sociedade está mergulhada em um sistema movido pelo valor monetário, então as 
intenções, ações e dinâmicas serão alinhadas a este pressuposto de rentabilidade (SANTOS, 2003).

Especializar e separar são ações fundamentais no espaço capitalista. O capitalismo se apropria dos espaços para produção e reprodução de seus anseios, Carlos (1994) apresenta uma análise centrada sobre o urbano, mas, indo além, enxerga-se que a escola é - também - fundamental para esse processo. Tomar como clareza a concepção de que o ambiente escolar pode ser carregado de intencionalidades é uma tarefa que faz retomar os estudos de Foucault (1987; 1988). Em sua visão existe um processo de docilizar os corpos tentando enquadrá-los em um arquétipo estabelecido como necessário, sendo uma tarefa que ocorre em diversos campos sociais, inclusive, o das corporificações.

Quando se recorre em Engels (2014) é possível enxergar o quão estruturante a família é para a consolidação da propriedade privada, assim é entendível que perpetuar a visão patriarcal pode ser vital para o processo de acumulação do capital, dito isto, a escola é espaço desse mecanismo de indução. No caso brasileiroª , a escola é um dos primeiros espaços de sociabilidade da criança, o Ministério da Educação definiu os 4 anos de idade como ideal para ingresso na pré-escola.

Esse período de imersão em um espaço caracterizado pela reprodução de relações é fundamental para implantar o que Louro (2000) aponta como sendo as Pedagogias da Sexualidade, isto é, as crianças são instruídas em uma normatização daquilo que devem ser, o que nos retoma em uma ferramenta foucaultiana de existência (FOUCAULT, 1987; 1988).

Junckes e Silva afirmam que "a escola não é um espaço neutro [...] a escola marca com mais evidência as desigualdades de gênero, raça e sexualidade" (2009: 164), portanto este é o espaço da hegemonia dos valores patriarcais, cuja persistência da heteronormatividade, do machismo e do sexismo reafirmam as relações de poder apresentas por Raffestin (1993). Diante disso, o debate de gênero se faz necessário como superação do estabelecimento de normas a serem seguidas.

O espaço escolar é local de (re)produção desses papéis por serem estruturantes na formação da sociedade, o que faz retomar ao que Milton Santos postula, "o espaço organizado pelo homem é como as demais estruturas sociais, uma estrutura

3 Consulta em: https://novaescola.org.br/conteudo/12222/veja-o-que-mudou-ou-nao-na-idade-minima-para-ingresso-na-educacao-infantil-e-fundamental. Acesso em: 13 jan. 2019. 
subordinada-subordinante" (1978, p. 145). Dentro dessa lógica dual o gênero se encontra, movimentos que denunciam isto são visualizados através das redes sociais, por exemplo. Movimentos feministas e movimentos LGBTQIA+ encaminham com protagonismo estas pautas em busca de uma sociedade igualitária pois, "historicamente, as relações sociais entre homens e mulheres foram construídas de forma desigual, reforçando a submissão e a violência numa relação de gênero desigual que exclui e segrega" (COSTA, 2011, p. 77).

Induzir o gênero nas discussões acadêmicas, escolares e afins devem ser constantemente levantados como formas de combate ao capitalismo e às desigualdades. Retomando ao que Costa (2011) aconselha, debater gênero é buscar o rompimento dos papéis preestabelecidos e demarcados, assim seria emancipar todos e todas, independentemente da figura hegemônica, que para Louro (2000a) é protagonizada pelo homem branco, hétero e cristão. Posto isto, discutir gênero nos espaços coletivos é endossar que "a sexualidade e as relações de gênero não podem mais ser compreendidas como questões que se resolvem 'entre quatro paredes', simplesmente porque o que acontece entre quatro paredes tem a ver com o que está a acontecer lá fora e está ligado ao que está lá fora" (LOURO, 2000a, p. 44).

As escolas em sua luta de envolver os(as) estudantes com um discurso regulador quanto ao gênero e à sexualidade conseguem promover a vigilância, o disciplinamento e a normatização. Estas imposições, que são cotidianas e acabam sendo realizadas sutilmente ou nem mesmo são vistas, reafirmam o silenciamento e a exclusão de quem não está condizente a norma, pois:

as relações sociais em contextos escolares reproduzem a norma heterossexista e machista perante estes jogos de representações que, ao mesmo tempo em que discrimina e combate as outras representações de gênero e de orientação sexual, tomam estas como evidências simbólicas corporificadas necessárias para reforças às hierarquias de poder. (COSTA, 2016, p. 214)

Conforme Raffestin (1993) e Costa (2016) as relações de poder são inerentes nas relações sociais. Junckes e Silva em seu estudo trazem a escola como seletiva e institucionalizadora, para eles “a escola produz as 'pessoas normais' e desejáveis tanto quanto enuncia e exclui os 'não-normais' e os indesejáveis, segundo as regras elementares da alteridade" (2009, p.154). Assim, o desconhecimento da totalidade em termos de diversidade e alteridade acabam colocando este espaço em caráter 
repressor.

Quando se enxerga a multiplicidade analítica do espaço entende que o ideário de democracia, pluralidade e debate em torno do ambiente escolar deveria ser efetivado, mas, se esvai. $O$ trabalho escolar em torno do gênero e sexualidade que deveria ser em múltiplas nuances se restringe ou - por vezes - nem é realizado, exemplos disso são notados em atividades comuns das escolas como: (I) a divisão binária dos banheiros excluindo a gama de identidades existentes além de ser homem ou ser mulher; (II) a exclusividade de brincadeiras a certos perfis gênicos, comumente vemos o futebol para os meninos e o vôlei para as meninas; (III) sem contar com os nocivos discursos e atos de professores(as) e alunos(as) ligados a homofobia e assédio.

Exemplos listados acima são alguns dos milhares que existem. Dessa forma, a tarefa da escola, conforme Silva (2003, p. 21), "deve assumir uma posição democrática e participativa para a formação de cidadãos e contribuir para a melhoria da qualidade de vida", ou seja, pela busca do rompimento dos discursos e ações de cunho conservador. Essa tarefa almejada pela estudiosa é possível quando o ensino de Geografia se faz presente nas salas de aula de modo coerente as realidades sociais e espaciais. Costa (2011, p. 79) disserta sobre a importância de lecionar esta ciência, para ela "a Geografia, enquanto disciplina, tem, então, um papel importante na formação do cidadão consciente de seu papel na produção do espaço, dos seus direitos, nas suas práticas espaciais e sobre as relações entre homens e mulheres".

Portanto, trazer a discussão em um plano que a diferença esteja presente é objetivar a superação das discriminações, desigualdades e opressões, proporcionando o incentivo à cidadania e à ressignificação do olhar. Encaminhamentos similares podem ser depreendidos em outros teóricos e teóricas do ensino de Geografia (CAVALCANTI, 2012; KAERCHER, 1997; VESENTINI, 1994), que reconhecem a importância da formação cidadã e crítica dos(as) estudantes. Nesse sentido, o contra poder e/ ou a resistência perante as forças hegemônicas são ferramentas que elevam a busca de lutar por uma sociedade menos desigual, menos machista, misógina, homofóbica, enfim, é uma tentativa de reconstrução de sociedade. 
Mas, quando se busca combater esse movimento de normatização é necessário formação como postula Dinis (2008), pois o que está em jogo não é apenas dar visibilidade a outras formas de sexualidade ou a liberdade feminina (isto é visualizado através das personalidades da música, do cinema, etc!). O cerne do combate está no confronto ao ideário de família, ao patriarcado e a todo o discurso que existe ao redor da propriedade privada (FEDERICI, 2017). Sendo então uma forma de tornar o espaço um lugar do confronto, onde as ideias são debatidas tornando, sim, um espaço educativo.

Dessa forma, construir uma estratégia de embate e resistência se funda no aporte de vivência e do compromisso político-educacional dos que estão cotidianamente no espaço escolar. A busca por preconizar estudos e práticas sobre a igualdade de gênero, a visibilidade das sexualidades e tudo que abarca a educação sexual que, muitas vezes, não são incorporadas como obrigatoriedade curricular, podem vir a ser realizadas nas entrelinhas de atividades e propostas pedagógicas.

Buscando no tocante desta indicação metodológica é apontado como ferramenta de trabalho educativo a realização de uma tarefa que pode iniciar as discussões ligadas à igualdade de gênero. Tentando incentivar os(as) estudantes em uma busca de trabalhar a expressividade e o poder de criticidade é indicado que façam discussões encaminhadas através de motivações que partem de vídeos publicados na plataforma Youtube. A escolha de calcar a atividade em recursos visuais perpassa pelo estudo de Bandeira (2009) que enxerga o ensino em uma ótica contemporânea de informatização do ambiente escolar e dos próprios sujeitos em aprendizagem, para tal escolhemos dois vídeos para auxiliar na escrita.

O primeiro é do canal Tempero Drag (intitulado "Rita em 5 minutos: Gênero e natureza"4), neste curto espaço de tempo é explanado por Rita Von Hunty sobre o processo de normatização dos corpos para desempenho de papéis pré-estabelecidos socialmente. Outra motivação parte do vídeo realizado pela ONU Mulheres Brasil² $^{2}$ êr seus pouco mais de dois minutos é evidenciado a disposição destes papéis

$4 \quad$ Neste vídeo é apresentado uma abordagem sociológica sobre a construção do gênero. Disponível em: https://www.youtube.com/watch?v=vK3koljeWoc\&t=262s. Acesso em: 20 jan. 2020. $5 \quad$ Intitulado "Igualdade de Gênero", o vídeo aponta exemplificações do cotidiano de mulheres e homens na sociedade brasileira, com dados que comprovam a desigualdade que há entre os gêneros. Disponível em: https://www.youtube.com/watch?v=ZCGLC-vziRc. Acesso em: 20 jan. 2020. 
sociais a cada perfil, apresentando dados que comprovam a desigualdade entre homens e mulheres, e entre brancos(as) e negros(as).

Tentar pautar uma ação de conscientização dessa forma pode ser melhor desenvolvida com estudantes do Ensino Médio, indagando as realidades e as dinâmicas imbricadas nessa temática. Partindo disso, as atividades sobre o gênero são, também, geográficas.

Esse ato educativo deve ser inserido nas aulas de Geografia pois, como Cavalcanti (2012) e Vesentini (1994) defendem, ela deve buscar um ensino de indagação, esclarecimento, emancipação e cidadania. Assim como de toda a escola, afinal a temática pode ser trabalhada independente de disciplinas, visto que assola a comunidade como um todo. Dessa forma, destaca-se por meio dos estudos de Fazenda (1994) a importância da interdisciplinaridade, enquanto algo analítico, dialético e realista.

\section{CONCLUSÃO}

Como é visível, "o trabalho espacial deve conter o sentimento de provocação dos 'porquês', 'para quês', 'para quem'. O 'quando' e o 'como' são indispensáveis no entendimento do processo" (CASTROGIOVANNI, 2000, p. 14), assim, o papel do ensino geográfico deve proporcionar $\mathrm{a}(\mathrm{o})$ estudante reflexões ante as relações socioespaciais, bem como suas dinâmicas. A tarefa de propor novos olhares a(o) estudante de Geografia ante seu espaço é uma ação embrionária de resistência frente as desigualdades e as investidas de retrocesso, como é o Escola Sem Partido. Portanto, a resistência é tarefa cotidiana, educativa e geográfica.

Buscar uma sociedade igualitária perpassa por democratizar a discussão de gênero e sexualidade nos ambientes escolares, isto é evidente nas defesas de Louro (2000). Pautar essas discussões são formas de embate e tensionamento contra as estruturas do capitalismo e a normatização dos papeis sociais historicamente construídos (JUNCKES; SILVA, 2009). Endossando os apontamentos em Costa (2011) e Silva (2003), um ensino em/de Geografia deve aflorar a cidadania, a discussão social. 
Portanto, o temor que surge com o Escola sem Partido é justamente quanto a multiplicação de uma sociedade que reproduz o discurso hegemônico de personificação acerca do gênero. Assim como, levar a discussão à sala de aula é demarcar a categoria de gênero como necessária para entendimento das ações socioespaciais, sendo um método de análise e de reflexão.

\section{REFERÊNCIAS}

BANDEIRA, Denise. Material didático: conceito, classificação geral e aspectos da elaboração. In: CIFFONE, H. (Org.). Curso de Materiais didáticos para smartphone e tablet. Curitiba: IESDE, 2009.

CARLOS, A. F. A. A (re)produção do espaço urbano. São Paulo: EdUSP, 1994.

CASTROGIOVANNI, A. C. Apreensão e compreensão do espaço geográfico. In: A. C. (org.). Ensino de Geografia: práticas e textualizações no cotidiano. Porto Alegre: Mediação. 2000.

CAVALCANTI, L. S. O ensino de geografia na escola. Campinas: Papirus, 2012.

L. S. Geografia e educação no cenário do pensamento complexo e interdisciplinar. Boletim Goiano de Geografia, Goiânia, v. 22, n. 2, 2002.

COSTA, B. P. A escola como espaço: identidades de gêneros e sexualidades e suas hierarquias. Revista ANPEGE, v. 12, n. 19, p. 204 - 225, 2016.

COSTA, C. L. A presença e ausência do debate de Gênero na Geografia do Ensino Fundamental e Médio. Revista Latino-americana de Geografia e Gênero. Ponta Grossa, v. 2, n. 2, p. 76-84, 2011.

DINIS, N. F. Educação, relações de gênero e diversidade sexual. Educação e Sociedade, Campinas, v. 29, n. 103, p. 477-492, 2008.

ENGELS, F. A origem da família, da propriedade privada e do Estado. Rio de Janeiro: Bestbolso, 2014.

FEDERICI, S. Calibã e a Bruxa: mulheres, corpo e acumulação primitiva. São Paulo: Elefante, 2017.

FOUCAULT, M. História da Sexualidade: a vontade do saber. Rio de Janeiro: Graal, 1988. 

, M. Vigiar e punir. Petrópolis: Vozes, 1987.

JUNCKES, I. J.; SILVA, J. M. Espaço escolar e diversidade sexual: um desafio às políticas educacionais no Brasil. Revista de Didácticas Específicas, n.1, p. 148-166, 2011.

KAERCHER, N. A. Desafios e utopias no ensino de Geografia. Santa Cruz do Sul (RS): EDUNISC, 1997.

LOURO, G. L. O corpo educado: pedagogias da sexualidade. Belo Horizonte: Autêntica, 2000.

, G. L. Currículo, género e sexualidade. Porto, PT: Porto Editora, 2000a.

MADUREIRA, A. F. A. Gênero, sexualidade e diversidade na escola: a construção de uma cultura democrática. 2007. Tese (Doutorado em Psicologia). Universidade de Brasília, Brasília, 2007.

RAFFESTIN, C. Por uma geografia do poder. São Paulo: Ática, 1993.

SANTOS, M. Por uma geografia nova. São Paulo: EDUSP, 1978.

, M. Por uma outra globalização: do pensamento único à consciência universal. Rio de Janeiro: Record, 2003.

SILVA, M. V. Geografia e Gênero: uma abordagem no Ensino Médio nas escolas da rede pública em Catalão/Goiás. 2003. Monografia. Universidade Federal de Goiás, Catalão, 2003.

VESENTINI, J. W. Ensino de Geografia e luta de classes. In: OLIVEIRA, A. U. (org.). Para onde vai a Geografia?. São Paulo: Contexto, 1994. 


\section{FORMAÇA DE CONCEITOS DE} APRENDIZAGEM GEOGRÁFICA POR ALUNOS COM TRANSTORNOS DO ESPECTRO AUTLSTA:

\section{ENFASE NA MEDLAÇÃO DO PROCESSO}

$\rightarrow \rightarrow \rightarrow \rightarrow-\rightarrow \rightarrow$

SANDRA MARA SOARES FERREIRA

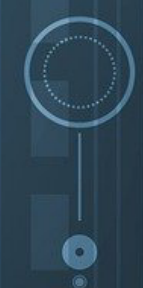

MAURICIO COMPIANI

1 Graduação em Pedagogia (UEPG); Graduação em Geografia (Unicesumar); mestrado em Ensino de Ciência e Tecnologia (UTFPR); doutorado em Ensino de Ciências e Matemática (Unicamp). Professora da rede estadual de ensino do Paraná. Email: sandrawmara@gmail.com

2 Graduação em Geologia (USP); mestrado em Educação (Unicamp); doutorado em Educação (Unicamp); livre docência (Unicamp). Professor titular da Universidade Estadual de Campinas. Coordenador do Programa de Multiunidades de Ensino de Ciências e Matemática (PECIM) da Unicamp. Membro do grupo de pesquisa gepCE da FE- Unicamp. Email: compiani@unicamp.br 


\section{INTRODUÇÃO}

A inclusão de alunos com transtornos do espectro autista está cada vez mais frequente em escolas de ensino regular. Esse processo corroborou para que estes alunos chegassem aos anos finais do ensino fundamental.

Em todo o contexto escolar e, principalmente em sala de aula, as especificidades dos alunos com transtornos do espectro autista são inúmeras e extremamente relevantes, e ignorá-las ou minimizá-las interfere diretamente nos processos de ensino e aprendizagem. Quando se trata de assuntos que estejam fora do foco de interesse específico, esses alunos tendem a tornarem-se alheios, indiferentes ou impacientes. Mas podem se mostrar também muito motivados quando um assunto lhes desperta interesse, evocando seu conteúdo em diversas situações.

Mesmo com peculiaridades e características individuais formando uma díade, que contempla o prejuízo persistente na comunicação social recíproca e na interação social e também os padrões restritos e repetitivos de comportamentos, e ainda que alguns ainda apresentem comorbidades (APA, 2014), não são em todos os casos que alunos com transtornos do espectro autista apresentam comprometimentos cognitivos. Ao contrário, os que chegam a frequentar os anos finais do Ensino Fundamental normalmente apresentam habilidades para a leitura, para a escrita, para os cálculos. Com grande capacidade de armazenamento de uma gama de informações requintadas de acordo com o foco de interesse, muitas vezes são considerados autistas de alto funcionamento. Embora não seja regra, podem também apresentar habilidades especiais para o Esporte, ou ainda para a Matemática, Arte ou Música. Entretanto, para esses alunos, o processo de aprendizagem nem sempre se concretiza quando os conteúdos são organizados apenas na forma expositiva, o que compromete o entendimento e/ou dificulta as abstrações.

Nesse contexto, uma das disciplinas que clama por constante mediação docente individual e maiores subsídios visuais ou concretos é certamente a Geografia, por se constituir em uma ciência de síntese, pela interdependência com a visualidade, pela especificidade com que trata os fenômenos naturais e humanos e pelas singularidades que envolvem os alunos com autismo. 
O termo 'conteúdos de aprendizagem', aqui utilizado, foi cunhado por Zabala (1999) e designa o conjunto de aprendizagens de uma disciplina contido em uma proposta educacional. Desse modo, os conteúdos de aprendizagem geográfica exigem o domínio de saberes que são historicamente produzidos no âmbito da ciência e precisam despertar o interesse dos alunos, principalmente quando se materializam em práticas sociais e se verificam fenômenos vistos ou divulgados frequentemente na mídia. A Geografia, enquanto ciência e enquanto disciplina escolar abrange conceitos considerados fundamentais que precisam ser contextualizados para que os significados se construam e para que ganhem sentidos (PONTUSCHKA, PAGANELLI e CACETE, 2009).

O ensino da Geografia, pelas relações e desafios que proporciona e por abranger o conhecimento de fenômenos naturais, sociais e culturais naturalmente apresenta aos alunos novidades, avanços e descobertas. Mas são evidentes a importância e a necessidade de uma aproximação entre os conteúdos escolares, o cotidiano e a realidade dos alunos.

Castellar (2005) defende a ideia de que a Geografia enquanto ciência e área do conhecimento escolar precisa eleger uma abordagem didático-metodológica que possibilite o desenvolvimento de um raciocínio estratégico, a fim de oportunizar ao educando sua efetiva aprendizagem, principalmente no que diz respeito às concepções contemporâneas, tornando-se explicação dinâmica do espaço geográfico.

A definição de uma abordagem didático-metodológica que atenda às especificidades dos alunos com transtornos do espectro autista é importante e fundamental.

\section{DESENVOLVIMENTO}

Em Geografia, alguns conceitos estruturantes são considerados pré-requisitos e precisam ser fundamentados de forma coerente para que seja possível a compreensão gradual e conceitual dos conteúdos de aprendizagem abordados pelo professor. A globalização, por exemplo, que é um fenômeno complexo e diverso, suscita da eliminação de barreiras entre os países e afeta as instâncias social, tecnológica, cultural, econômica, resultando na construção de espaços de relações integradas (CAVALCANTI, 2010). 
Compreende-se assim que, no mundo contemporâneo, as práticas cotidianas das pessoas (que são práticas espacializadas e por isso interessam à geografia) são complexas, fragmentadas, desiguais, diferenciadas, multiculturais, interculturais, desterritorializadas/reterritorializadas, organizadas em fluxos e redes, midiáticas e informatizadas. (CAVALCANTI, 2010, p. 20)

Nesse contexto, nos últimos anos, novas temáticas alavancam os estudos geográficos que envolvem o entendimento de sistemas complexos da paisagem, da natureza e da sociedade, com o enfoque plural do espaço enquanto seu foco de análise (CAVALCANTI, 2010).

Para Lisboa (2008), durante a caminhada escolar, cada aluno entra em contato com uma gama de informações que dizem respeito ao espaço geográfico brasileiro e mundial. Assim,

Em cada conteúdo que lhe é apresentado, faz-se necessário a compreensão de vários conceitos geográficos que se constituem como instrumentos para uma aprendizagem efetiva. Dessa forma, entende-se que um contato introdutório com os conceitos geográficos apresenta grande potencial para possibilitar, posteriormente, o entendimento do conteúdo estudado. Ainda que não haja uma discussão introdutória abordando conjuntamente os conceitos, é importante que à medida que seja necessária a compreensão de cada conceito no interior do assunto estudado, ele seja compreendido. (LISBOA, 2008, p.25)

O professor, ao apresentar questões propositivas à formação do conceito de espaço geográfico e ao espaço enquanto totalidade precisa conduzir o processo de forma que a construção da ideia de espaço se formule em sua dimensão cultural, econômica, ambiental e social. Em razão de diversas representações sociais, o aprofundamento de fenômenos geográficos necessita de uma análise conceitual ampla, em que o aluno realmente conceba o processo de construção da espacialidade. (CASTELLAR, 2005).

Há um longo e cuidadoso processo educacional para que o aluno possa chegar a refletir sobre "a realidade, a sociedade e a dinâmica do espaço", como aponta Castellar (2005, p.212), pois a compreensão das relações que se estabelecem no espaço, principalmente no que diz respeito à localização, configura-se em uma dificuldade aos alunos.

A percepção do espaço na perspectiva da geografia é uma abordagem que devemos analisar. (...) Para que a criança entenda, perceba o espaço e consiga, através da percepção, fazer a sua representação é importante que não 
só as noções espaciais tenham sido estimuladas e construídas, mas que também estejam adequados o processo de aprendizagem e o conteúdo ensinado. (CASTELLAR, 1996, p.93)

Nesse sentido, a interconexão de conceitos e a convergência de conteúdos demonstram que a Terra e a natureza são constantemente modificadas, construídas e reconstruídas pela ação do homem. Sociedade e espaço compilam contrastes, e modernidade, problemas ambientais, sociais e urbanos, disparidades regionais, qualidade de vida são engendramentos que acarretam contradições, e por isso precisam ser compreendidos (VESENTINI, 1998).

Assim, alguns conceitos, como lugar, paisagem, região, natureza, sociedade, território são fundamentais para a construção do raciocínio espacial, constituindo-se em referência para a estruturação dos conteúdos de aprendizagem (CAVALCANTI, 2010).

Entretanto, se esses conceitos são inicialmente abstratos e pode ser grande a dificuldade em compreender cada um deles para qualquer aluno, para os alunos com transtornos do espectro autista essas questões se complexificam. Por mais que algumas palavras pareçam ou soem com familiaridade, suscitando aproximações, podem também derivar uma reprodução mecânica de um conceito que foi anteriormente decorado. Além disso,

[...] um conceito é mais do que a soma de certos vínculos associativos formados pela memória, é mais do que um simples hábito mental; é um ato real e complexo de pensamento que não pode ser aprendido por meio de simples memorização [...]. (VYGOTSKY, 2001, p. 246)

Sob a ótica de Vygotsky (2007), no desenvolvimento psicológico, a memória, mais do que o pensamento abstrato, constitui-se em uma característica que define os primeiros estágios do desenvolvimento cognitivo, que será transformada na adolescência, quando as relações interfuncionais que envolvem a memória invertem sua direção. Assim, para o adolescente, lembrar significa pensar, pois sua memória está tão carregada de lógica, que o processo de lembrança se reduz a estabelecer e encontrar relações lógicas. Nesse caso, o ato de reconhecer consiste na descoberta daquele elemento que a tarefa solicitada exige.

Na proposição da definição dos conceitos, como não havia pré-requisitos formais, a não ser o que foi vivenciado tacitamente, a capacidade de síntese foi com- 
prometida pela dificuldade em estabelecer alguns parâmetros verbais e conceituais que os auxiliassem na compreensão desses conceitos. Por isso, a sondagem inicial sobre um tema específico pode ser um bom diagnóstico para que o professor situe o nível de aprendizado de seus alunos, incluindo o poder de síntese. Para Vygotsky,

(...) a síntese de dois elementos não é a simples soma ou justaposição desses elementos, mas a emergência de algo novo, anteriormente inexistente. Esse componente novo não estava presente nos elementos iniciais: foi tornado possível pela interação entre esses elementos, num processo de transformação que gera novos fenômenos. (OLIVEIRA, 2002, p. 23)

Tomando por base o pensamento de Compiani (2013), sobre a descrição dos conceitos geográficos pelos alunos, a proposição solicitada não recebeu explicação prévia, não trouxe marcas observáveis que lhes permitisse estabelecer relações, nem puderam remeter nenhuma experiência passada. Não houve nenhum código que pudesse desvendar as relações de causa de sua origem. Não lhes foi assegurado nenhum recurso visual que ampliasse as possibilidades de se compreender a dimensão dos conceitos propostos. Isso não ocorreu pelo fato de os alunos apresentarem o transtorno do espectro autista. De forma alguma, pois qualquer aluno poderia trazer o mesmo tipo de resposta. A formulação de hipóteses se deu num vácuo conceitual, num vazio vocabular e por isso a descrição foi extremamente breve, objetiva, parcial e sem fundamentos científicos.

(...) o ensino é o processo de conhecimento do aluno mediado pelo professor. Ensinar é uma intervenção intencional nos processos intelectuais e afetivos do aluno buscando sua relação consciente e ativa com os objetos de conhecimento. O objetivo maior do ensino, portanto, é a construção do conhecimento mediante o processo de aprendizagem do aluno. A intervenção intencional própria do ato docente diz respeito à articulação de determinados objetivos, conteúdos e métodos que levem em conta as condições concretas em que ocorre o ensino e seus diferentes momentos, planejamento, realização e avaliação. (CAVALCANTI, 2010, p. 137-138)

Quando a aula se compõe de forma dialógica, e vai além da exposição oral dos conteúdos de aprendizagem, a intervenção intencional recebe como resposta a participação e o envolvimento dos educandos principalmente com relação aos questionamentos, o que pode contribuir para que o professor localize os conhecimentos prévios de seus educandos. 
Esta investigação traz uma proposta com enfoque descritivo de três casos, que abrangem o transtorno do espectro autista, com o mesmo laudo diagnóstico (CID-10 F84.0) priorizando a abordagem qualitativa, e organizando os fatores intervenientes numa relação de causa e efeito (KUME, 1993), mas contemplando principalmente os aspectos contextual e perceptivo.

Ao definir como fio condutor a mediação docente individual, este trabalho permitiu que, além da reflexividade crítica suscitada no decorrer de toda a investigação, também se pudesse fazer uso da observação das formas de tratamento aos conteúdos de aprendizagem geográfica no processo histórico-social no contexto em que ele se deu, para os alunos com transtornos do espectro autista, a partir da premissa de que as relações que se estabelecem por meio do alcance da mediação docente, intervêm diretamente em três eixos:

- Eixo 1: Inteligibilidade da comunicação do educando por meio de relações dialógicas;

- Eixo 2: Abordagem metodológica adequada ao desenvolvimento das funções psicológicas superiores;

- Eixo 3: Uso de recursos didático-pedagógicos, favorecendo os processos de percepção visual e abstração.

A abrangência da mediação docente nestes três eixos possibilitariam a apreensão dos conteúdos de aprendizagem geográfica aos alunos que apresentam o transtorno do espectro autista. Houve a preocupação em analisar os processos constitutivos dos conteúdos de aprendizagem geográfica e as formas de abstração, a partir da mediação docente individual, empregando diferentes abordagens metodológicas e utilizando recursos visuais, recursos concretos e manipuláveis no auxílio ao desempenho de funções psicológicas superiores, como atenção voluntária e memória, para a apreensão dos conteúdos de aprendizagem em Geografia no espaço escolar. A figura 1 explica o alcance da mediação docente neste estudo. 
Figura1 - Alcance da mediação docente

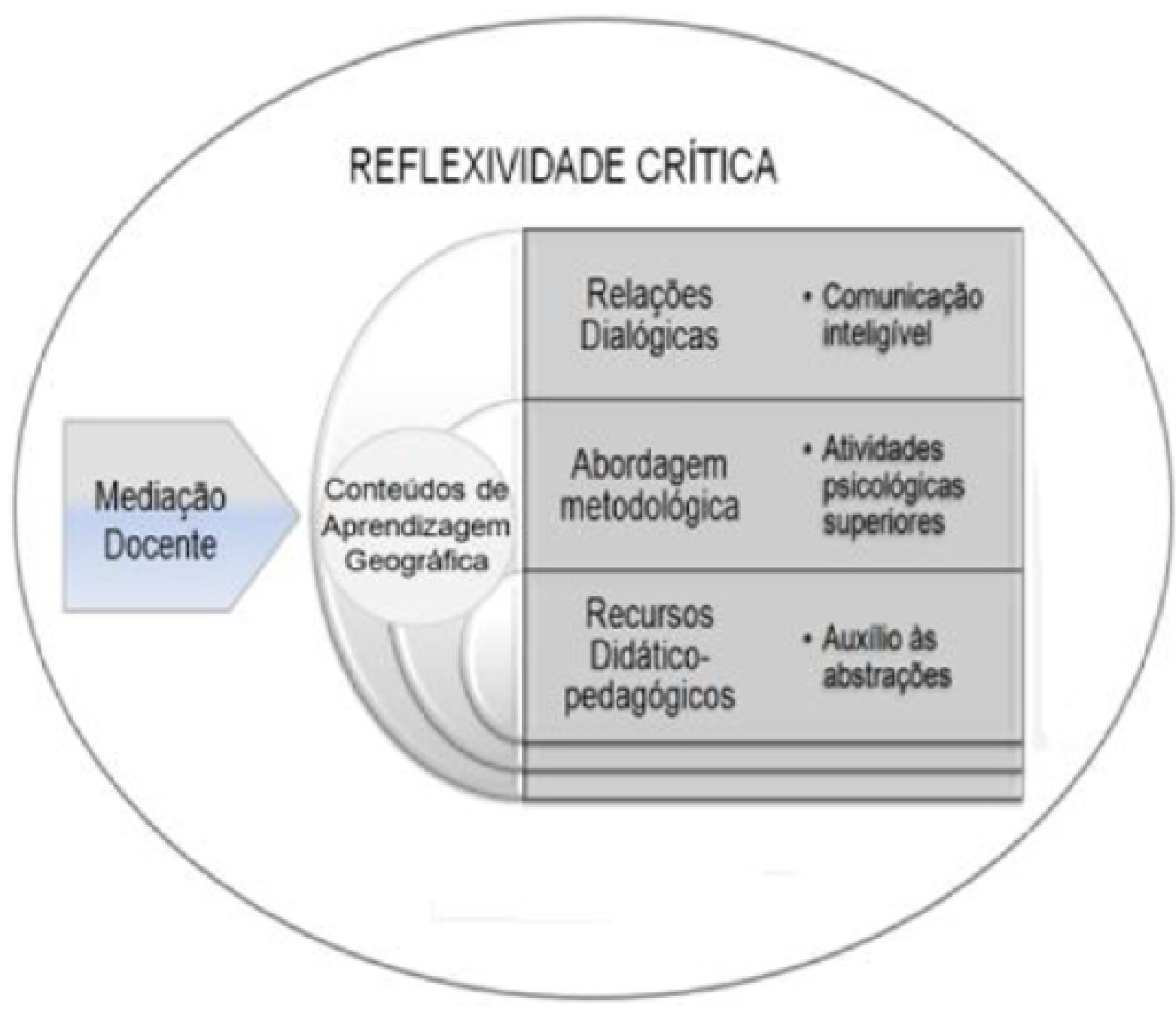

Fonte: Autores.

Trata-se de um fragmento do estudo feito com os alunos com transtornos do espectro autista, em que se registrou os avanços com relação aos conteúdos de aprendizagem geográfica a partir da mediação docente individual. Numa sondagem diagnóstica inicial, para que se pudesse localizar o que os alunos sabiam ou pensavam sobre os conceitos considerados estruturantes da disciplina de Geografia, ou ainda, como agiam quando se deparavam com processos e com conceitos mais teóricos utilizados com frequência pelos professores, foram solicitados a descrever cada um desses conceitos de maneira espontânea, e que fossem registrando suas respostas. 
Quadro 1 - Percepção dos conceitos geográficos por alunos com transtornos do espectro autista

\begin{tabular}{|c|c|c|c|}
\hline CONCEITOS & Aluno 1 & Aluno 2 & Aluno 3 \\
\hline LUGAR & "O mundo inteiro". & "O outro lado". & "Escola" \\
\hline PAISAGEM & "Beleza natural". & "Um lugar de paz". & "Praça" \\
\hline REGIÃO & "Onde eu moro". & "Fica em um país". & "Paraná" \\
\hline NATUREZA & $\begin{array}{c}\text { "Prova que Deus } \\
\text { existe". }\end{array}$ & $\begin{array}{c}\text { "Lugar de árvores, } \\
\text { animais e plantas". }\end{array}$ & "Plantas" \\
\hline TERRITÓRIO & $\begin{array}{c}\text { "Demonstra } \\
\text { posse". }\end{array}$ & "Que é de alguém". & "Terreno" \\
\hline
\end{tabular}

Fonte: Autores.

Para Vygotsky (2007), para crianças, pensar significa lembrar, por isso a definição de um conceito baseia-se em suas lembranças concretas. O conteúdo do ato de pensar tem caráter sincrético, refletindo uma dependência entre o pensar e sua memória. Além disso, nesse ato (o de pensar), há a transposição de uma relação aprendida a partir de estímulos para outro conjunto similar, denotando um processo de transferência, em que a lembrança se dá por meio de exemplos isolados. As associações que ocorrem são definidas a partir de exemplos, construídos analogamente a representações dos nomes das classes de elementos.

Emitir palavras, para as crianças, não é tanto indicar conceitos conhecidos como é nomear classes conhecidas ou grupos de elementos visuais relacionados entre si por certas características visualmente comuns. Dessa forma, a experiência da criança e a influência não mediada dessa experiência estão registradas na sua memória e determinam diretamente toda a estrutura do pensamento da criança pequena. (VYGOTSKY, 2007, p. 48-49)

A busca pela compreensão de até aonde o aluno chegou, em termos conceituais, é fundamental no processo de ensino e aprendizagem. Nesse caminho, "o aprendizado escolar produz algo fundamentalmente novo no desenvolvimento", uma vez que o aprendizado precisa ser combinado com o nível de desenvolvimento (VYGOTSKY, 2007, p. 95). 
Do ponto de vista geográfico, na dialética de suas relações e de seus fenômenos, o conhecimento de como o aluno pensa a respeito de cada uma das categorias espaciais, é primordial para o entendimento dos conceitos.

Tais conceitos não são exclusivos da ciência geográfica, sendo utilizados, também, por outras ciências e pelo senso comum de diferentes formas e com diversas acepções. Por essa razão, a Geografia precisa considerar seus diferentes significados, do mesmo modo que a análise das representações dos alunos e professores dos conceitos geográficos escolhidos deve ser enriquecida pelo estudo desses conceitos nas suas formulações científicas. Afinal, essas formulações científicas são referências básicas para a estruturação dos conteúdos da Geografia ensinada na escola. (CAVALCANTI, 2010, p.88)

O lugar de convívio dos alunos, assim como o próprio contexto escolar podem ser pontos de partida para a "construção de conceitos constitutivos da especificidade do conhecimento geográfico" (CALLAI, 2010, p.25). A partir da observação do meio e do entendimento de que é possível alterar produtivamente o desempenho de um aluno a partir da interferência de outra pessoa sobre essa compreensão, e que essa interferência se constitui em interação mediadora, trará a esse aluno um grande benefício na construção de conceitos.

\section{RESULTADOS E DISCUSSÃO}

O aluno1 foi bastante pontual em suas respostas. Porém, deixou clara a sua concepção do conceito de lugar como localidade, abrangendo-o como "o mundo inteiro". Não o relacionou com sua experiência e não demonstrou relações de afetividade. Para ele, a paisagem remete ao belo e é sinônimo de beleza natural. A seu modo, compreende o conceito de território como espaço delimitado por relações de poder. Ao conceito de natureza acrescenta um sentido de fé religiosa. Atribuiu ao conceito de região a denominação de sua área regional, e compreende território como área sobre a qual se exerce autoridade e posse.

O aluno 2 apresentou respostas evasivas, sem muita certeza para todos os conceitos. Ao demonstrar uma resposta relativamente evasiva ('O outro lado'), o conceito de lugar não lhe remeteu a algo familiar, que faz parte de sua vida. Empregou o verbete 'paisagem' para definir um estado de espírito. A região para ele fica em um espaço longínquo, remete à subdivisão de um espaço, embora sem nenhuma inter- 
-relação espacial. No conceito de território demonstrou que estabeleceu ligação com relações de poder.

O aluno 3 foi extremamente sucinto e objetivo em suas respostas, utilizando uma palavra-chave para definir cada um dos conceitos propostos.

Para nenhum deles (aluno 1, aluno 2 e aluno 3) o conceito de paisagem se relaciona diretamente aos sentidos, como estabelece Santos (1988). Paisagem está ligada ao belo (aluno 1), à tranquilidade (aluno 2) ou a um local específico (aluno 3).

Para Vygotsky a relação do homem com o mundo não é uma relação direta. É essencialmente uma relação mediada por elementos e ferramentas auxiliares da atividade humana. Mediação, nesse caso, seria entendida como o processo de intervenção de uma relação, utilizando-se de um elemento intermediário. Desse modo, toda relação deixa de ser imediata e direta. Passa a ser uma relação mediada pelo elemento intermediário. Assim, todos os tipos de relações do homem com o mundo são relações mediadas, uma vez que suas funções psicológicas superiores apresentam uma estrutura que necessita de ferramentas auxiliares que comunicam a atividade humana, sejam elas instrumentos ou signos (OLIVEIRA, 2002).

As representações espaciais, presentes historicamente no cotidiano do homem e por meio de símbolos e desenhos, o homem representa suas apreensões da realidade, delimita e ocupa efetivamente o seu território, tem nas técnicas cartográficas cada vez mais precisão e simbolizações próximas do real (SILVA e CARVALHO, 2011).

Maquetes, mapas cartas e plantas são representações sociais de um determinado espaço real e representam uma organização dos elementos que compõem o espaço. São modelos de comunicação que se utilizam de uma linguagem cartográfica. A leitura das representações cartográficas requer o domínio desta linguagem, representada por símbolos. (CASTROGIOVANNI, 2009, p. 37)

Para uma representação compreensiva do enlace entre palavras isoladas, descontextualizadas e a conceituação de termos conceituais, enriquecidos de significado, os alunos com transtornos do espectro autista necessitariam por certo da explicação prévia do professor que, por meio de exemplificações, demonstrações e associações, direcionaria o olhar e o entendimento desses alunos. 
Sabemos que a explicação se faz a partir de uma série de marcas observáveis, e as mesmas só podem ser estudadas por associações e semelhanças com outras feições. Duas cognições são importantes: primeiro, a forma deve ser identificada como significativa, e, para isso, é operado todo um arcabouço de experiências passadas entre feições e informações de processos contemporâneos para capacitar a mente observadora-interpretadora a perceber que tais feições são indicativas (são índices de uma relação físico-existencial apontando para seu objeto de que ele é parte) de um processo passado. A outra cognição, então, é transformar esta forma em 'forma fixada', ou seja, num símbolo que embute códigos que desvendam as relações de causa de sua origem. Esta divisão em duas cognições é artificiosa, porém é importante reter que a procura do registro já direciona as duas cognições. A primeira cognição é mais descritiva e, (...) posso afirmar que é aquela em que o desenho é fundamental para o discernimento de algum padrão. A segunda cognição é mais explicativa, a utilização do padrão discernido serve para dar base fatual à formulação de hipóteses que transformem as formas em evidências de supostas causas de suas origens. (COMPIANI, 2013, p. 719)

Sendo representação simbólica do espaço concreto, que se utiliza da linguagem semiótica complexa, a figura cartográfica se apresenta com signos, projeções e escala. Desse modo, o mapa compreende um signo; é um símbolo que representa o espaço geográfico de forma bidimensional reduzida. A elaboração de um mapa envolve "conhecimento do espaço geográfico, e sua codificação é que traduz em imagem o significado, o conteúdo". Por outro lado, a leitura de um mapa necessita da decodificação dos conteúdos de forma significativa e com possíveis (novas) significações, pois, de acordo com a escala proposta, assume diferentes possibilidades de interpretação. (CASTROGIOVANNI, 2009, p. 37).

Em sala de aula, alguns estímulos artificiais podem ser incorporados, denominados por Vygotsky como signos e instrumentos, cuja "analogia básica repousa na função mediadora que os caracteriza" e, portanto, "podem ser incluídos na mesma categoria" (Vygotsky, 2007, p. 53). Porém, existem diferenças entre os dois conceitos em relação ao comportamento, pois o esquema humano representa diferentes meios de adaptação a estímulos.

O instrumento, para Vygotsky, é elaborado para que se possa atingir um objetivo, e por isso carrega consigo a função que o define e para o qual foi criado e designado para as ações concretas, pela sua utilização no decorrer da história do trabalho coletivo. É, ao mesmo tempo, um objeto social e também um elemento mediador na relação com o indivíduo. Desse modo, um machado ou um recipiente para armazenar água seriam instrumentos que o homem produziu para funções específicas 
(OLIVEIRA, 2002).

Já o signo, como meio auxiliar no desenvolvimento das funções psicológicas superiores, age no campo psicológico. São orientados para o próprio indivíduo, para dentro, e se dirigem ao controle de ações psicológicas do próprio indivíduo ou de outras pessoas. Em sua forma elementar, constituem-se numa marca externa, que auxiliam na memória e na atenção. Assim, ao fazer uso de varetas para registrar algo na areia ou ao utilizar pedras para contagem, o homem está fazendo uso de signos. Estes, "são interpretáveis como representação da realidade e podem referir-se a elementos ausentes do espaço e do tempo presentes" (OLIVEIRA, 2002, p. 30).

Com orientação interna ou externa, nas aulas de Geografia, são inúmeras as possibilidades de se utilizar os signos e os instrumentos como elementos auxiliares no desempenho das funções psicológicas superiores. A listagem dos estados e suas respectivas capitais; o uso de mapas para visualizar os domínios geomorfológicos; o uso de diagramas e gráficos para compreensão da densidade demográfica nas diferentes regiões; a rosa dos ventos como auxilio a localização dos pontos de orientação (cardeais, colaterais e subcolaterais), são exemplos da utilização de signos.

Os instrumentos também podem ser muito utilizados. Um compasso, por exemplo, pode facilitar a ilustração do globo terrestre, tornando mais próxima a sua representação; e o uso de escalímetro é útil na representação de escalas, facilitando a conversão proporcional.

Portanto, a percepção do espaço, de sua utilização e de sua representação pode partir de representações espaciais gráficas, utilizando-se de desenhos, mapas, croquis, maquetes. Para a criança, a iniciação cartográfica contém uma multiplicidade de atributos, os quais reúnem a informação qualitativa, a informação ordenada e a informação quantitativa, tornando-se indispensável para o desenvolvimento do imaginário infantil (PONTUSCHKA, PAGANELLI e CACETE, 2009).

Mesmo com a amplitude que carrega o termo região no âmbito geográfico, os sujeitos participantes apresentaram dificuldades em pontuar o conceito de região referindo-se à noção fundamental de diferenciação de área, ou seja, à aceitação da ideia de que a superfície da Terra é constituída por áreas diferentes entre si (COR$R \hat{E A}, 2002)$. E certamente, não conheciam a origem etimológica da palavra região, que vem do latim regere, cujo radical reg originou outras palavras, como regência, 
regente, regra, atribuindo ao termo região, um caráter político, ao se referir à unidade político-territorial que dividia o Império Romano (GOMES, 2010; CORRÊA, 1997).

O conceito de território, que é carregado e elaborado a partir e por relações de poder foi assim percebido pelo aluno 1 e aluno 2. Mas não perceberam o território como um campo de forças ou de territorialidades flexíveis (SOUZA, 2010). A questão de que o território se relaciona diretamente aos processos de construção e transformação do espaço geográfico, foi, de certo modo, mencionado pelo aluno 3 , mesmo que sua percepção tenha sido de forma inconsciente.

Todos esses conceitos que envolvem o espaço são reconhecidamente familiares, e ao mesmo tempo abstratos e de difícil descrição. Promoveram, em sua maioria, conceituações ingênuas e objetivas, não compreendidos como resultantes da inter-relação dos objetos naturais e culturais (SANTOS, 2006). Os alunos 1, 2 e 3 demonstraram, porém, que nem sempre é preciso conhecimento ou profundo entendimento de um conceito para descrevê-lo de modo relativamente coerente, com alguma aproximação do real.

O fato de não dominarem o campo conceitual dos termos propostos demonstra que nem sempre os alunos apresentam ou dominam o vocabulário de uma área específica. Seja como for, "qualquer situação de aprendizado com a qual a criança se defronta na escola tem sempre uma história prévia" (VYGOTSKY, 2007, p. 94).

A distância entre o que o professor explica, explana, expõe, argumenta, informa, exemplifica e o que um aluno com transtornos do espectro autista apreende é longa e complexa.

Foi possível também verificar reiteradamente a dificuldade dos alunos na imediata compreensão da linguagem não verbal, do uso constante do tato, do isolamento social, das resistências a mudanças, das reações emocionais exageradas, da dificuldade em captar uma explicação e a inabilidade em compreender o sentido de uma gravura em sua totalidade.

Se todo ato educativo implica na inter-relação de duas ou mais pessoas, constituintes de um complexo processo simbólico-discursivo, em que se articulam ideias, metas, conceitos, definições, argumentos, exemplificações, informações, orientações, Professor e aluno são elementos constituintes de um processo de ensino e aprendizagem, cuja finalidade é o conhecimento. 
A linguagem verbal, seja pelo uso da escrita ou da fala, é o meio de comunicação mais comum em sala de aula, uma vez que cada professor estabelece uma forma própria e constante de realizar o seu fazer pedagógico. É importante reafirmar que essa característica previsível é positiva para os alunos com transtornos do espectro autista, que apreciam a rotina.

Em sala de aula, não existe a possibilidade de seguir uma prescrição, uma vez que o exercício da profissão docente é essencialmente prático e dinâmico e por isso não se sustenta a partir de modelos ou receitas. Somente a partir do constante trânsito entre a teoria e a prática, e do entendimento de que eu precisaria refletir sobre as minhas ações, fui construindo sentidos cotidianamente. Assim, minha prática foi sustentada com base em elementos teóricos que me instrumentalizaram em todo esse processo extremamente singular. Nesse contexto, a reflexividade constituiu-se em uma autoanálise racional sobre as ações discentes e docentes.

\section{REFERÊNCIAS}

ANDRÉ, M. E. D. A. Estudo de caso: seu potencial na educação. 1984.

AMERICAN PSYCHIATRIC ASSOCIATION et al. DSM-V: Manual Diagnóstico e Estatístico de Transtornos Mentais. 5 ed. Porto Alegre: Artmed, 2014.

. DSM-IV-TR: Manual diagnóstico e estatístico de transtornos mentais: texto revisado. Artmed, 2002.

CASTELLAR, S. M. V. Educação geográfica: a psicogenética e o conhecimento escolar. Cad. Cedes, Campinas, v. 25, n. 66, p. 209-225, 2005.

. Noção de Espaço e Representação Cartográfica: ensino de Geografia nas séries iniciais. São Paulo (1996).

CAVALCANTI, L. S. A geografia escolar e a cidade: ensaios sobre o ensino da geografia para a vida urbana cotidiana. Campinas-SP: Papirus, 2010.

COMPIANI, M. Contribuição para reflexões sobre o panorama da Educação Ambiental no ensino formal: da Educação Ambiental no Ensino Fundamental, p. 43, 2001. 
perspectiva. 3 ed. São Paulo: Contexto, 2006.

. O lugar e as escalas e suas dimensões horizontal e vertical nos trabalhos práticos: implicações para o ensino de ciências e educação ambiental. Ciência \& educação, v. 13, n. 1, p. 29-45, 2007.

. Projeto Ribeirão Anhumas na Escola: fundamentos pedagógicos e educacionais. Ribeirão Anhumas na Escola: projeto de formação continuada elaborando conhecimentos escolares relacionados à ciência, à sociedade e ao ambiente. Curitiba: CRV 1 (2013): 11-35.

Verbal e visual, análise e síntese no ensino de ciências: um olhar geológico como ciência histórica. Revista Brasileira de Pesquisa em Educação em Ciências, v. 15, n. 3, p. 555-579, 2015.

CORREAA, R. L. Espaço, um conceito-chave da Geografia. In: CASTRO, I. E.; GOMES, Paulo César da Costa; CORREAA, Roberto Lobato (Org.). Geografia: conceitos e temas. $3^{\mathrm{a}}$ ed. Rio de Janeiro: Bertrand Brasil, 2001.

GOMES, P. C. C. O conceito de região e sua discussão. In: CASTRO, I. E.; GOMES, P. C. C; CORREAA, R. L. (Org.). Geografia: conceitos e temas. Rio de Janeiro: Bertrand Brasil, 2010.

GIL, A. C. Estudo de caso. São Paulo: Atlas, 2009.

KUME, H. Métodos estatísticos para melhoria da qualidade. São Paulo:Gente, 1993.

LIBÂNEO, J.C. Reflexividade e formação de professores: outra oscilação do pensamento pedagógico brasileiro? In: PIMENTA, S. G.; GHEDIN, E.Professor reflexivo no Brasil: gênese e crítica de um conceito. São Paulo: Cortez, 2002.

. Didática. São Paulo: Cortez, 2009.

- O dualismo perverso da escola pública brasileira: escola. Educação e Pesquisa, v. 38, n. 1, p. 13-28, 2012.

LÜDKE, M.; ANDRÉ, M. E. D. A. Pesquisa em educação: abordagens qualitativas. São Paulo: EPU, 2013.

LISBOA, S. S.. A importância dos conceitos da geografia para a aprendizagem de conteúdos geográficos escolares. CEP, v. 36570, p. 000, 2008. 
OLIVEIRA, M. K. Vygotsky: Aprendizado e desenvolvimento: um processo sócio-histórico. São Paulo: Scipione, 2002.

PONTUSCHKA, N. N.; PAGANELLI, T. L.; CACETE, N. H. Para aprender e ensinar geografia. São Paulo: Cortez, 2009.

SANTOS, M. Metamorfose do espaço habitado. São Paulo: Hucitec,1988.

. Estrutura, Processo, Função e Forma como categorias do método geográfico: Espaço e Método. São Paulo: Nobel, 1985.

O espaço: sistemas de objetos, sistemas de ações. Anais do IV Encontro nacional da ANPUR, p. 35-39, 1991.

1992: a redescoberta da Natureza. Estudos avançados, v. 6, n. 14, p. 95-106, 1992.

Por uma outra globalização: do pensamento único à consciência universal. Rio de Janeiro: Record, 2000.

.A urbanização brasileira. São Paulo: Edusp, 2005.

Crescimento nacional e nova rede urbana: o exemplo do Brasil. Revista Brasileira de Geografia, v. 60, n. 1, p. 207-221, 2006.

A cidade e o urbano como espaço-tempo. Anais: Seminário de História da Cidade e do Urbanismo, v. 2, n. 1, p. 241-244, 2012.

SILVA, C. N.; CARVALHO, J. S. A representação espacial e a linguagem cartográfica. Revista GEOMAE - Geografia, Meio Ambiente e Ensino. V. 02, n. 3, 2011, p. 85-106.

SOUZA, M. J. L. O território: sobre espaço e poder, autonomia e desenvolvimento. In: CASTRO, I. E.; GOMES, P. C. C.; CORREAA, R. L. (Org.). Geografia: conceitos e temas. Rio de Janeiro, Bertrand Brasil, 2010

VESENTINI, J. W. Para uma geografia crítica na escola. São Paulo: Ática, 1998.

VYGOTSKY, L. S. Psicologia Pedagógica. São Paulo: Martins Fontes, 2001.

. Psicologia Pedagógica - Edição Comentada. Porto Alegre: Artmed,

2003.

Obras escojidas V: Fundamentos de Defectologia. Madri: Visor, 
Fontes, 1999.

A construção do pensamento e da linguagem. São Paulo: Martins

Aprendizagem e Desenvolvimento Intelectual na Idade Escolar. In: Vygotsky, L.S. et al. Psicologia e Pedagogia: Bases Psicológicas da Aprendizagem e do Desenvolvimento.São Paulo: Ed. Moraes, 1991.

A Formação Social da Mente. $6^{a}$ ed. São Paulo: Martins Fontes, 1998.

VIGOTSKY, Lev. S.; LÚRIA, Alexander. R; LEONTIEV, Alex. N. Linguagem, desenvolvimento e aprendizagem. 3.ed. São Paulo: Ícone/ ed. da USP, 1988. 


\section{ABP, CAMINHOS E POSSIBILIDADES PARA O ENSINO DE GEOGRAFIA}

CARLOS VINIGIUS ANTUNES RUFINI CARLOS HENRIQUE COSTA DA SILVA

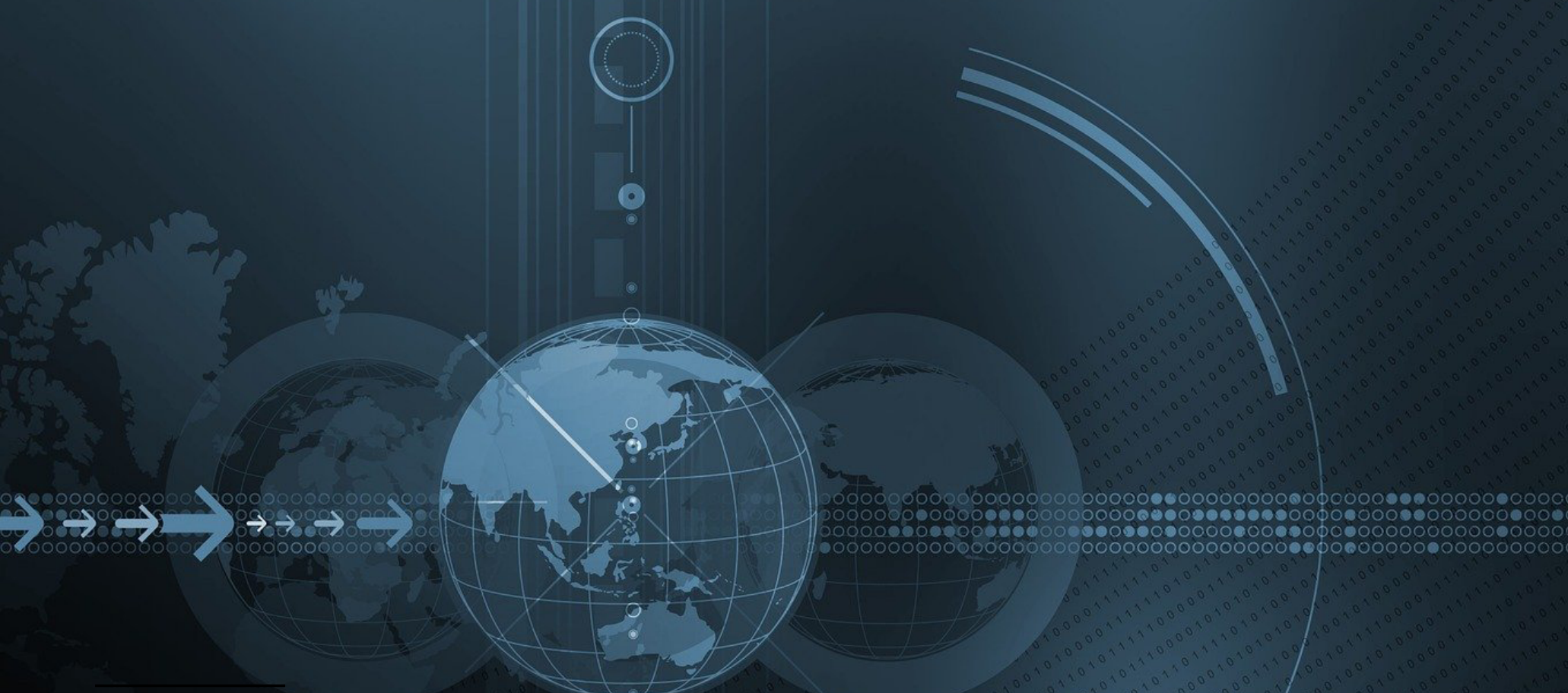

1 Jornalista e Professor de Geografia dos anos iniciais e finais no Colégio Mundo Novo - Sorocaba. carlos_rufini@msn.com

2 Professor Associado do Departamento de Geografia, Turismo e Humanidades e do Programa de Pós-graduação da UFSCar/Sorocaba. ricougo@ufscar.br 


\section{INTRODUÇÃO}

O ensino de Geografia centrado na figura do professor e dos conteúdos tem perpetuado uma estrutura pouco efetiva para o aprendizado e o desenvolvimento da criticidade. Poderiam as metodologias ativas como a Aprendizagem Baseada em Problemas (ABP) ou como em sua origem Problem Based Learning (PBL), ser uma estratégia que possibilite a inserção do aluno no seu próprio processo de aprendizado? Dessa participação autônoma do aluno, pode-se esperar uma formação crítica e transformadora de sua realidade?

A presente proposta pedagógica foi aplicada a 26 alunos do $9^{\circ}$ ano do ensino fundamental, em 2020, em plena pandemia da Covid19. Assim, foi realizada de maneira remota com limitado contato físico entre os estudantes, porém com a possibilidade de acesso aos meios de comunicação digital.

Os dados coletados a partir das produções dos alunos (representados por letras do alfabeto) são objeto de investigação deste artigo, e os denominamos de "falas significativas". Os dados selecionados de maneira aleatória representam as respostas de dez alunos, com o objetivo de destacar falas significativas que evidenciam a inserção do estudante no processo de aprendizagem de maneira crítica e transformadora através das propostas pela prática pedagógica "A Ásia Conecta o Comércio Mundial?", pela ABP.

O Ensino de Geografia sempre se destacou por ser uma área que traz a possibilidade de reflexão sobre a inter-relação homem versus natureza, bem como compreender as consequências e transformações que o espaço sofre devido a ação natural e/ou antrópica. Ou seja, por sua multiplicidade e por discutir diversas áreas do conhecimento, a Geografia é uma ciência que tem como seu laboratório o Mundo, é dinâmica e viva, assim como as relações sociais que ela estuda.

Neste sentido, buscamos discutir processo histórico que a disciplina de Geografia está inserida, tendo a pretensão de explicar o "mundo como ele é", apoando em livros didáticos e seus infindáveis exercícios, deixando pouco espaço para o debate, perguntas e principalmente o aluno como protagonista do processo de aprendizagem (KAERCHER, 2004). 
Memorização de informações, resumos de capítulos do livro didático e resolução de questões que são cópia e cola de trechos do livro didático no caderno, são algumas das observações de Girotto (2015) sobre a aplicação da geografia em sala de aula. Estas têm a urgente necessidade de mudanças em grande parte dos processos desenvolvidos ali e, desta forma, o aprendizado adquirido nas escolas, passará a ter uma significância para toda vida. Concordamos com Callai (1995) ao afirmar que a escola deve trabalhar na formação de cidadãos que possam estar aptos às adversidades e complexidades impostas pelo século XXI, e por isso, repensar as relações de ensino-aprendizagem é essencial.

Para Cachinho (2010), a renovação da prática docente, passa pela mudança das metodologias de ensino-aprendizagem, pois as práticas de ensino tradicionais não conseguem mais dar conta das demandas da sociedade contemporânea, onde cada vez mais busca-se o desenvolvimento de habilidades de inter- relacionar o conhecimento teórico com a vivência prática, por isso, a aplicação de metodologias ativas em sala de aula é uma alternativa, tendo o estudante como protagonista do seu aprendizado.

Dentre as diferentes metodologias ativas que podem ser propostas em sala de aula, optamos pela Aprendizagem Baseada em Problemas, tendo como referências para sua construção a Aprendizagem através da Experiência desenvolvida por John Dewey (1978) e a Aprendizagem Significativa trabalhada por David Ausubel (2000).

Dentro dos estudos desenvolvidos por Dewey (1978), não é possível separar a vida da educação, pois todos os processos desenvolvidos pelo estudante dentro da escola são experimentações que reverberam fora dela, por tanto, "a educação torna-se, desse modo, uma contínua reconstrução de experiências". (DEWEY, 1978, p. 7).

Enquanto Dewey (1978) busca um aprendizado através da experiência, David Ausubel (2000)entende que a aprendizagem ocorre através da construção de significado do conteúdo estudado pelo aluno, rompendo a lógica mecânica de aprendizado. Sendo assim, Ausubel, possibilita que o aluno coloque seus conhecimentos teóricos construído, para solucionar situações-problemas reais, potencializando o desenvolvimento de uma aprendizagem significativa (AUSUBEL, 2000), 
As construções metodológicas desenvolvidas por Dewey (1978) e Ausubel (2000), convergem na perspectiva de priorizar o estudante, através da valorização dos seus interesses dentro do conteúdo programático das aulas, trazendo maior significado para o processo de aprendizagem, onde o professor deixa de ser o detentor do conhecimento e atua como um mentor no desenvolvimento educacional do estudante.

Dentro do contexto de transformação das práticas pedagógicas, devemos buscar maneiras de trazer para sala de aula situações que podem ser vivências fora dela, por isso, a Aprendizagem Baseada em Problema (ABP) adquiriu destaque dentre as práticas de metodologias ativas. Segundo Cachinho (2010), deve-se ao fato de ser uma prática centrada no aluno, através de atividades em grupo com o objetivo de solucionar problemas, por meio do desenvolvimento de estratégias facilitadoras para tomada de decisões e a formação do pensamento crítico.

Todavia, Cachinho (2011) ressalta, que não devemos acreditar que a ABP é a solução de todos os problemas enfrentados dentro da sala de aula, mas uma inovação didática que permite desenvolver experiência de aprendizagem significativa e que possam auxiliar na resolução de problemas ao longo de toda a vida do estudante.

\section{DESENVOLVIMENTO}

A aplicação da ABP foi desenvolvida através da proposta pedagógica chamada de "A Ásia Conecta o Comércio Mundial?", que foi desenvolvida em cinco etapas, tendo como referência a Base Nacional Comum Curricular (BNCC)

Estudar Geografia é uma oportunidade para compreender o mundo em que se vive, na medida em que esse componente curricular aborda as ações humanas construídas nas distintas sociedades existentes nas diversas regiões do planeta. (BRASIL, 2018, p.359)

Em especial no $9^{\circ}$ ano, o foco da disciplina de geografia é "abordar a constituição da nova (des)ordem mundial e a emergência da globalização - mundialização, assim como suas consequências." (BRASIL, 2018, p. 383). Através da análise da visão construída sobre o Ocidente e o Oriente, desde o processo de expansão marítima e comercial, que resultou em um Sistema Colonial em escala mundial. Essa 
construção histórica é importante para compreensão e contextualização dos processos que resultaram na formação dos Estados Modernos e na imersão sociocultural e geopolítica que vivemos através da Globalização, em especial, a relação da China com o ocidente.

Com o objetivo de trabalhar situações - problemas geográficos que contextualizam questões da Ásia e da Europa, tendo como referência a Aprendizagem Baseada em Problema, buscou-se a construção de uma atividade que pudesse ser realizada no último trimestre de 2020 e de maneira que fosse adequada ao sistema de aulas remotas devido à Pandemia do Covid-19.

Dentre diferentes possibilidades de questões geopolíticas mundiais, optou-se pela Iniciativa OBOR (Um Cinturão, Uma Estrada) também conhecida como Nova Rota da Seda, projeto desenvolvido pelo Governo Chinês, que busca uma integração entre África, Ásia e Europa. Trata-se de tema importante pois,

[...] se difere da globalização tradicional na medida em que a sua proposta possui o potencial de proporcionar uma globalização inclusiva, sem assimetrias entre o marítimo e o terrestre; o urbano e o rural; os países desenvolvidos e os em desenvolvimento. (PAUTASSO, UNGARETTI, 2017, p. 30)

Além disso, a Iniciativa OBOR (Um Cinturão, Uma Estrada), deve ser analisada como um tema transversal, pois possibilita contemplar inúmeras habilidades que são descritas na BNCC:

\section{Quadro 1 - Competências da BNCC.}

\begin{tabular}{|c|c|}
\hline Gódigo & Competência \\
\hline (EF09GE01) & $\begin{array}{c}\text { Analisar criticamente de que forma a hegemonia europeia foi exercida em } \\
\text { várias regiões do planeta, notadamente em situações de conflito, interven- } \\
\text { ções militares e/ou influência cultural em diferentes tempos e lugares. }\end{array}$ \\
\hline (EF09GE02) & $\begin{array}{r}\text { Analisar a atuação das corporações internacionais e das organizações } \\
\text { econômicas mundiais na vida da população em relação ao consumo, à } \\
\text { cultura e à mobilidade. }\end{array}$ \\
\hline (EF09GE05) & $\begin{array}{r}\text { Analisar fatos e situações para compreender a integração mundial } \\
\text { (econômica, política e cultural), comparando as diferentes interpretações: } \\
\text { globalização e mundialização. }\end{array}$ \\
\hline (EF09GE07) & $\begin{array}{r}\text { Analisar os componentes físico-naturais da Eurásia e os determinantes } \\
\text { histórico-geográficos de sua divisão na Europa e Ásia. }\end{array}$ \\
\hline
\end{tabular}




\begin{tabular}{|c|c|}
\hline (EF09GE08) & $\begin{array}{l}\text { Analisar transformações territoriais, considerando o movimento de fronteiras, } \\
\text { tensões, conflitos e múltiplas regionalidades na Europa, na Ásia e na } \\
\text { Oceania. }\end{array}$ \\
\hline (EF09GE09) & $\begin{array}{c}\text { Analisar características de países e grupos de países europeus, asiáticos e } \\
\text { da Oceania em seus aspectos populacionais, urbanos, políticos e } \\
\text { econômicos, e discutir suas desigualdades sociais e econômicas e pressões } \\
\text { sobre seus ambientes físico-naturais. }\end{array}$ \\
\hline (EF09GE09) & $\begin{array}{c}\text { Analisar características de países e grupos de países europeus, asiáticos e } \\
\text { da Oceania em seus aspectos populacionais, urbanos, políticos e } \\
\text { econômicos, e discutir suas desigualdades sociais e econômicas e pressões } \\
\text { sobre seus ambientes físico-naturais. }\end{array}$ \\
\hline (EF09GE10) & $\begin{array}{l}\text { Analisar os impactos do processo de industrialização na produção e } \\
\text { circulação de produtos e culturas na Europa, na Ásia e na Oceania. }\end{array}$ \\
\hline
\end{tabular}

Fonte: Quadro elaborado pelo autor.

O processo de construção desta proposta pedagógica buscou alinhar as habilidades propostas na BNCC com uma temática que tenha aproximação com o cotidiano dos estudantes, através do comércio global impulsionado pela globalização, todavia, encontra-se paralisado devido a pandemia do Covid-19.

\section{$1^{\text {a }}$ Etapa: Do que se trata a Rota da Seda?}

Ao longo do $2^{\circ}$ trimestre, os temas trabalhados em sala de aula flutuavam entre os aspectos físico e socioculturais da Eurásia, desenvolvendo uma perspectiva de como as trocas entre as diferentes culturas foram importantes para a construção do que entendemos hoje como ocidente. Buscando compreender mais sobre as relações entre Ásia e Europa, foi sugerido a leitura da reportagem "Espíritos da Rota da Seda" publicada pelo site da National Geographic português, onde foi possível ter o primeiro contato com relatos sobre a antiga Rota da Seda. Através do interesse despertado sobre o tema, buscou-se a construção de uma atividade cuja abordagem partiria de uma única questão: “A Ásia Conecta o Comércio Mundial?”

\section{$2^{a}$ Etapa: Construção do Fórum de Integração da Rota da Seda}

Dos 26 alunos integrantes da sala, 20 foram selecionados para representar os países representantes no Fórum de Integração da Rota da Seda e seis foram selecionados para executarem a função de jornalista, acompanhando os debates e fazendo a cobertura e divulgação dos diferentes acontecimentos. Para análise das falas significativas e evidências de aprendizagem, os alunos foram identificados com 
as letras do alfabeto.

A escolha das diferentes funções dentro do Fórum foram realizadas através de uma roda de conversa e buscando o consenso nas escolhas. Os países foram selecionados tendo como referência os principais blocos econômicos e organizações multinacionais, onde os países têm representatividade geopolítica e sobre os interesses na discussão sobre a Rota da Seda, sendo posições favoráveis ou contrárias.

$3^{a}$ etapa: Análise das relações Geopolíticas.

Com o objetivo de aproximar os estudantes da realidade geopolítica do país escolhido, os estudantes desenvolveram uma investigação sobre a relação do Estado que representa com as demais nações e seu interesse na construção da Nova Rota da Seda.

A pesquisa foi desenvolvida, especialmente, através da análise de notícias, através de portais conhecidos para evitar notícias falsas e estar atento às datas das publicações, pois o tempo é um fator que influencia na mudança das relações geopolíticas dos países. Para uma compreensão mais ampla desse cenário buscou-se sempre ao menos 5 notícias, para ter uma contextualização mais ampla sobre a relação entre os países.

No caso dos veículos de imprensa, o objetivo dos estudantes era compreender o posicionamento do jornal dentro do cenário político local e internacional, pois isso deveria influenciar em sua atuação dentro da cobertura do Fórum de Integração da Rota da Seda, de maneira positiva ou negativa.

$4^{\text {a }}$ Etapa: Comunicando.

Nesta etapa, os estudantes que representam as nações, elaboraram ao longo de duas semanas a parte escrita do discurso a ser apresentado na cerimônia de abertura do Fórum, devendo ter duração de dois a quatro minutos, apresentando as visões do seu país sobre a rota da seda, estabelecendo alinhamento de acordo com os seus interesses e até mesmo provocar possíveis países rivais.

No caso dos estudantes que representam os veículos de imprensa, o objetivo desta etapa é a construção do perfil de algum dos líderes políticos que se destacaram no Fórum, através da elaboração de uma entrevista questionando a visão e os objetivos do seu país com a Rota da Seda e até mesmo os possíveis problemas que essa iniciativa pode gerar em sua perspectiva. 
Como estamos vivendo em um cenário de um jornalismo multiplataforma, foi sugerido que o estudante realizasse a entrevista por vídeo e posteriormente pudesse transformar em um podcast, extraindo apenas o áudio e uma reportagem, no estilo "Páginas Amarelas" da Revista Veja, através da transição das respostas.

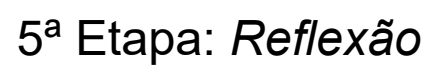

Com o intuito de estimular a reflexão e verificar o processo de formação crítica do estudante, como última etapa, foi solicitado a entrega de duas questões, onde foi possível sistematizar o conteúdo trabalhado ao longo do trimestre. A primeira questão teve como objetivo estimular o estudante a relacionar o processo de globalização e o comércio internacional, sendo ela respondida de maneira escrita. Para segunda questão, optou-se em uma alteração no formato de entrega, solicitando que os alunos enviassem áudios realizando uma reflexão sobre a concepção construída sobre a Nova Rota da Seda.

\section{Quadro 2 - Relação das Perguntas}

\section{$1^{\text {a }}$ Pergunta}

O que mudou na sua visão sobre Globalização e Comércio internacional após a construção desse projeto?

\section{$2^{\text {a }}$ Pergunta}

Como você compreender o projeto da Nova Rota da Seda depois dessa atividade?

Fonte: Quadro elaborado pelo autor.

\section{RESULTADOS E DISCUSSÃO}

Dentre as disciplinas presentes no ambiente escolar, segundo Girotto (2015), a geografia sempre teve destaque pela sua capacidade de reflexão sobre as complexidades envolvendo a relação homem versus natureza. No entanto, é necessário transpor uma tendência de aulas voltadas para a memorização de informações, realização de resumos de capítulos do livro didático e resolução de questões.

Entre as possibilidades de renovação da sala de aula, a Aprendizagem Baseado em Problema, que segundo Cachinho (2011) apresenta a oportunidade de trazer 
o estudante para o centro da aprendizagem, através da vivência de experiências significativas, com a possibilidade de desenvolver trabalhos coletivos e individuais, de maneira que possa auxiliar o desenvolvimento da autonomia, responsabilidade e criticidade.

Uma das principais preocupações, segundo Callai (1995), é como as escolas estão trabalhando na formação de cidadãos que possam estar preparados para enfrentar as complexidades apresentadas pelo século XXI. Por isso, ter o estudante como o foco principal da aprendizagem foi um dos principais objetivos do desenvolvimento da proposta pedagógica chamada de "A Ásia Conecta o Comércio Mundial?"

A construção da proposta, seguindo os princípios da ABP, procurou proporcionar momentos de estudos individuais e coletivas, durante a etapa que os estudantes deveriam pesquisar e analisar questões sobre o posicionamento internacional de cada país e de que maneira a imprensa deveria se portar. Buscou-se construir um ambiente que possibilitasse liberdade, cooperação e responsabilidade na tomada de decisões, principalmente em um ambiente de aula remota, onde os estudantes estão em suas casas.

Por isso, para além do conteúdo, uma das principais ações realizadas pelo docente ao longo dessa etapa, foi estimular a prática social dos estudantes, como elemento de construção do seu conhecimento (ANASTASIOU; ALVES, 2004). Os estudantes que representavam a imprensa, construíram uma dinâmica de chamadas de vídeos com o objetivo de cooperação entre eles. Já os países por ser um grupo maior de alunos, procuraram se organizar de acordo com a familiaridade, ou seja, cada aluno tinha como objetivo um caminho, porém, com a possibilidade de compartilhar informações relevantes com os demais.

Essa liberdade em trabalhar em grupo, sem a supervisão direta do professor, tem como função estimular o pensamento autônomo dos estudantes. Para Berbel (2011), é necessário criar situações de postura ativa, onde terá a oportunidade de se posicionar de maneira crítica e construtiva dentro da sua aprendizagem.

O professor deixa de lado a posição de como única fonte de conhecimento, segundo Kaercher (2004), o bom educador deve ter planejado o seu "suicídio pedagógico", a fim de orientar o processo de desenvolvimento pedagógico do estudante, através do estímulo a tomada de decisões, buscar por referências e apoiar em situa- 
ções de dificuldade.

Até o início da atividade, nenhum dos alunos do $9^{\circ}$ ano, tiveram contato próximo o suficiente para compreender logo o processo de construção e execução de um discurso de chefe de Estado, o professor, assume um papel de desafiador, trazendo referências, mostrando possibilidades, todavia, respeitando sempre a autonomia do estudante.

Por ser uma sala com interesse diversificado, os resultados acontecem de maneira distintas, com isso, Cachinho (2010), lembra que nem todos os alunos podem ter o mesmo interesse na execução das etapas por diferentes motivos. Em nosso caso, foi possível constatar através do grupo dos EUA, composto pelos estudantes $\mathrm{B}, \mathrm{H}$ e U, que apenas copiaram o seu discurso de um site de notícias, não podemos considerar como um insucesso da ABP, mas sim uma situação de aprendizado para o professor, pois assim, como o erro vindo do estudante deve ser visto de maneira positiva, o docente deve refletir sobre as tomadas de decisões e prováveis adeptos futuras com o intuito de mitigar situações futuras parecidas.

Todavia, é possível analisar que o processo de estímulo à autonomia e o controle do aluno sobre a sua aprendizagem pode resultar em uma formação crítica e transformadora, pois ao analisar os trabalhos e as respostas apresentadas ao final do Fórum em uma abordagem qualitativa identificamos falas significativas.

A elaboração do discurso foi um momento cujo os estudantes buscaram cristalizar diversas informações para um único objetivo, demonstrar a importância ou sua objeção para com o projeto da Nova Rota da Seda. Como é o caso do estudante L, representante da Itália, que durante suas pesquisas notou a constante busca pelo não posicionamento, com o intuito de evitar tensões geopolíticas. Por isso, ele conclama que "devemos manter a paz, sendo uma disputa em relação a Nova Rota da Seda desnecessária" e arremata buscando laços históricos da Itália com os Chineses através de Marco Polo. Na produção audiovisual, é possível notar que além da parte escrita com palavras em italiano, o mesmo buscou trabalhar com os trejeitos corporais típicos de um italiano, através da entonação da fala e na forma de gesticular.

Situação semelhante pode ser observada na produção do estudante $\mathrm{G}$, por ser representante do Brasil, buscou construir seu discurso em certos momentos, de maneira ufanista, conforme o trecho que ele fala sobre as exportações agrícolas sendo 
"coração pulsante da economia brasileira". Além disso, em seu discurso, ele coloca as questões para além da Nova Rota da Seda, como as tensões entre o $5 \mathrm{G}$ chinês no Brasil, devido a sua proximidade com os EUA, "nossas ligações com os Estados Unidos estão mais fortes do que nunca", buscou informações para além da proposta com o objetivo de justificar o seu posicionamento.

Porém, nem todos os países têm uma posição de protagonista dentro da discussão. A aluna $V$, representante do Sudão, buscou em seu discurso abordar as dificuldades do seu país, ressaltando a ajuda chinesa no desenvolvimento local "com investimentos em pontes, estradas, hospitais e outras instalações públicas". Tendo a entrevista ao jornalista da AI Jazira, uma oportunidade de cobrar os EUA da retirada de seu país da lista de Estados que financiam o terrorismo.

Essa construção do painel de relações geopolíticas, do discurso e da entrevista, auxiliou em um processo de reflexão própria, percebendo a posição de país marginalizado. Segundo a aluna $\mathrm{V}$, "parece ser escada, pois não vão ter uma grande influência ou protagonismo nesse projeto". Por esta resposta é possível fazer uma ponte com as respostas apresentadas pela maioria dos alunos quando foi realizada uma reflexão sobre a relação entre a Globalização e o Comércio Internacional, como é expressado pelo estudante $O$, "Deu pra perceber como todas as relações entre os países tem um tipo de interesse, não importa qual seja."

A construção da ABP para o professor acarretará inicialmente em um maior tempo de trabalho, devido a necessidade de um planejamento prévio das etapas a serem percorridas, de maneira que o estudante possa ter diferentes possibilidades de construção. Por isso, o professor deve estar preparado, pois dentro desse cenário, a sua dinâmica de aula pode sofrer alterações de acordo com a sala. Todavia, entendemos que essa dinâmica torna o ato da docência mais significativo, pois passamos a atuar mais próximo dos alunos, através de situações que realmente geram interesse. Por isso, a construção de uma bagagem de conteúdos diversificados é um fator importante na elaboração de atividades da ABP.

As dinâmicas apresentadas na construção desse Fórum são algumas possibilidades de práticas pedagógicas. Pensando em um cenário sem pandemia, a atividade poderia ser realizada através de uma cúpula de discussão entre os países, cenário de inúmeras possibilidades, onde a construção da dinâmica da atividade ficaria 
a cargo dos estudantes, gerando uma vivência real dos problemas entre os países.

Em um primeiro momento, pode se pensar que pelo fato do professor não estar lecionando diretamente, o aprendizado acontecerá de maneira limitada. Porém, o que ocorre é um processo de aprendizagem individual, onde o professor passa atuar como mediador do processo, auxiliando os estudantes de acordo com as suas dificuldades e colocando desafios quase que de maneira individual.

Desta maneira, a ABP apresenta-se como uma importante ferramenta pedagógica na construção de aulas mais interessantes e dinâmicas, pois, por entender que a autonomia da aprendizagem do estudante, seja uma peça chave, o professor tem a possibilidade de auxiliar no engajamento de alunos que apresentam maior dificuldade ou desinteresse no conteúdo a ser lecionado, buscando assim, uma atuação mais ampla e democrática em sala de aula.

\section{CONCLUSÃO}

O presente artigo buscou analisar a Aprendizagem Baseada em Problemas como uma possibilidade para ser aplicada dentro das aulas de Geografia e não a solução para todas as dificuldades presentes no ambiente escolar. No entanto, é necessário ter a ciência da necessidade da superação do ensino de geografia voltado exclusivamente para o conteudismo, por isso, é necessário uma reflexão sobre o espaço que está sendo colocado o estudante dentro da escola.

O século XXI trouxe inúmeras tecnologias para sala de aula, porém, observamos ainda uma escola presa em um sistema que tem como foco principal o comprimento de cronogramas de livro didático, sem considerar o real interesse e relevância do assunto para o estudante.

Principalmente a geografia, que segundo Lacoste (1993), é constantemente referenciada como uma disciplina maçante, onde busca falar sobre tudo, porém de maneira genérica e distante da realidade do estudante, para Callai (1995), devemos buscar focar nos básico e assim buscar uma ruptura da linearidade dos processos, cedendo espaço para a construção de um pensamento complexo.

Essa transformação ocorre através da mudança da prática pedagógica, porém Cachinho (2010) alerta que não é apenas colocando itens tecnológicos dentro da sala de aula, precisamos centralizar o estudante no processo de ensino aprendiza- 
gem, através de uma repactuação entre professores e alunos.

Entre as dificuldades que a ABP apresenta, é que a sua construção e aplicação depende da construção de uma sinergia entre professor e estudantes, que em alguns casos é um processo inviável, especialmente nas escolas públicas como professor temporário, além de uma compreensão do corpo gestor sobre o processo, que pode interpretar como um processo que não gera aprendizado, pelo fato do professor não estar sobre o controle total da aula.

No entanto, quando existe tempo para a construção do $A B P$, os resultados são expressivos, especialmente dos estudantes, pois esse processo pedagógico é elaborado na mediação dos docentes e do conteúdo programático da BNCC, buscando assim trazer significância e proximidade as aulas de geografia, quebrando assim, um estigma sobre a disciplina ser conteudista e baseada em memorização de conceitos distantes da realidade vivida.

\section{REFERÊNCIAS}

ANASTASIOU, L. das G. C.; ALVES, L. P. Estratégias de ensinagem. In: ANASTASIOU, L. das G. C.; ALVES, L. P. (org.). Processos de ensinagem na universidade: pressupostos para estratégias de trabalho em aula. 3. ed. Joinville: Univille, 2004. p. $67-100$.

AUSUBEL, D. P. Aquisição e retenção de conhecimento: uma perspectiva cognitiva. Lisboa: Plátano, 2000.

BERBEL, N. Ap. N. As metodologias ativas e a promoção da autonomia dos estudantes. Semina: Ciências Sociais e Humanas, Londrina, v. 32, n. 1, p. 25-40, 2011.

BRASIL. Ministério da Educação. Base Nacional Comum Curricular. Brasília, DF, 2018.

$\mathrm{CACHINHO}, \mathrm{H}$. Aprendizagem baseada em problemas: desafios da sua implementação em ambientes de racionalidade técnica. In: PBL 2010 CONGRESSO INTERNACIONAL, São Paulo, 8-12 fev. 2010. Anais eletrônicos... Disponível em: http://each. uspnet.usp.br/pbl2010/trabs/trabalhos/TC0365-1.pdf. Acesso em: 20 dez. 2020.

CACHINHO, H. Inovações didáticas e ensino da geografia: do potencial da aprendizagem baseada em problema. In: CONGRESO IBÉRICO DE DIDÁCTICA DE GEOGRAFÍA: APORTACIONES DE LA GEOGRAFÍA EN EL APRENDIZAJE A LO LARGO DE LA VIDA, Málaga, 2011. Anais eletrônicos... Disponível em: https://www. 
researchgate.net/publication/262911992_Inovacoes_Didaticas_e_Ensino_da_Geografia_do_Potencial_da_Aprendizagem_Baseada_em_Problemas. Acesso em: 20 dez. 2020.

CALLAI, H. C. A formação do professor de geografia. Boletim Gaúcho de Geografia, Porto Alegre, v. 20, n. 1, 1995. Disponível em: https://seer.ufrgs.br/bgg/article/ view/38032. Acesso em: 27 dez. 2020.

DEWEY, J. Vida e educação. 10. ed. São Paulo: Melhoramentos, 1978.

GIROTTO, E. D. Formando leitores do mundo: algumas considerações sobre o ensino de geografia no mundo contemporâneo. Boletim Campineiro de Geografia, Campinas, v. 5, n. 2, 2015. Disponível em: http://agbcampinas.com.br/bcg/index.php/ boletim-campineiro/article/view/233. Acesso em: 27 dez. 2020.

KAERCHER, N. A. Quando a geografia crítica pode ser um pastel de vento. Mercator, Fortaleza, v. 3, n. 6, nov. 2004. Disponível em: http://www.mercator.ufc.br/mercator/article/view/126. Acesso em: 27 dez. 2020.

LACOSTE, Y. A geografia, isso serve, em primeiro lugar, para fazer a Guerra. Campinas: Papirus, 1993.

PAUTASSO, D.; UNGARETTI, C. R. A nova rota da seda e a recriação do sistema sinocêntrico. Estudos Internacionais, Belo Horizonte, v. 4, n. 3, p. 25-44, abr. 2017. 


\section{O QUE A COPA DO MUNDO DE FUTEBOL TEM A VER COM O ENSINO DE CARTOGRAFLA?}

\section{JOSEANE CARINA BORGES DE CARVALHO \\ MAURİCIO COMPIANI}

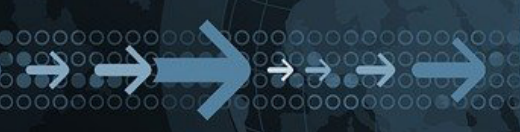
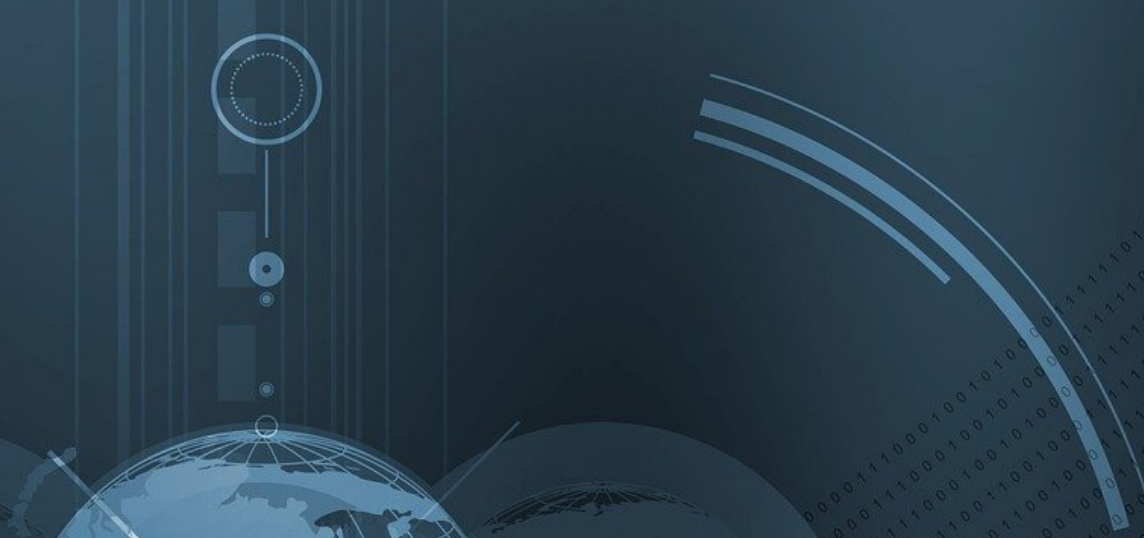

1 Professora de Geografia da rede pública estadual em Campinas, Mestra em Geografia (UNICAMP), Doutoranda pelo Programa de Pós-Graduação Multiunidades em Ensino de Ciências e Matemática - PECIM/UNICAMP. Email: joseanecarina@prof.educacao.sp.gov.br 2 Professor da Faculdade de Educação da Universidade Estadual de Campinas (UNICAMP). Email: compiani@unicamp.br 


\section{INTRODUÇÃO}

É no $6^{\circ}$ Ano do Ensino Fundamental (Anos Finais) que, o ensino e a representação do espaço geográfico se apresentam de uma forma mais sistematizada, pois é nesse momento que os (as) alunos (as) se deparam com a especialidade Geografia e seu conjunto amplo de fenômenos e conceitos a ela relacionados.

No que diz respeito particularmente à representação dos fenômenos geográficos, o seu ensino e aprendizagem tem se mostrado desafiador, provavelmente porque os conteúdos relacionados a esta temática tenham sido pouco trabalhados nos anos iniciais do Ensino Fundamental ( $1^{\circ}$ ao $5^{\circ} \mathrm{Ano}$ ) que em muito poderiam se relacionar tais conteúdos, a um conhecimento espacial que, em princípio, partiria de nossos próprios corpos, a partir das relações espaciais topológicas elementares (direita, esquerda, acima, abaixo, frente e atrás).

Assim, as observações que irão compor o presente estudo, surgem das vivências da autora relacionadas à sua docência na disciplina de Geografia no Ensino Fundamental - Anos Finais ( $6^{\circ}$ Ano), quando observava algumas dificuldades dos alunos apreenderem espacialmente os fenômenos ditos geográficos. Dessa maneira, ao dirigir um olhar atento sobre o conteúdo curricular presente nesse ano de ensino e, refletir sobre formas de se superar tais dificuldades, formas de ensino e aprendizagens contextualizadas surgiram como um procedimento que possibilitaria o desenvolvimento de atividades, que resultassem em um maior engajamento dos alunos e, consequentemente, que um maior conhecimento lhes fosse agregado.

Contudo, outro aspecto a ser considerado é o desafio de se alinhar tais propostas de ensino e aprendizado às diretrizes curriculares. No presente caso, trata-se do Currículo do Estado São Paulo (Secretaria da Educação, 2012), em pleno uso até o final de 2018. Mas vale destacar que não se pretende, aqui, elaborar um receituário inquestionável de atividades com base em um currículo oficial, tendo como pano de fundo para as mesmas, a contextualização no decorrer das práticas de ensino-aprendizagem. Sabe-se que o currículo oficial é a materialização de uma ação exclusiva e de controle do Estado, um importante instrumento de disseminação de valores de suas classes dirigentes, portanto, apresenta-se como possuidor de um importante 
papel político-ideológico.

Nesse sentido, acreditamos ser essencial que as práticas de ensino-aprendizagem sejam imbuídas de uma perspectiva crítico-dialógica, para que não caiamos no erro de nos tornarmos meros aplicadores de currículos junto de nossos (as) alunos (as). Para tanto, acredita-se que a Pedagogia Crítica do Lugar-Ambiente (COMPIANI, 2013; 2015), mostra-se como um caminho teórico-metodológico profícuo para se desenvolver estudos contextualizados e crítico-dialógicos no escopo das Geociências.

A comunidade escolar na qual se desenvolveu o presente estudo foi a da Escola Estadual Dr. Newton Oppermann, com seus alunos e alunas dos $6^{\circ}$ anos "A" e "B". Essa pertence ao Distrito do Campo Grande (Campinas, SP), região esta frágil no que tange aos aspectos socioeconômicos e ambientais, localizada em uma importante Bacia Hidrográfica, a do Córrego do Piçarrão.

\section{METODOLOGIA}

\section{PRINCÍPIOS TEÓRICOS}

Os referenciais teóricos desta pesquisa estão assentados nos estudos de uma Pedagogia Autônoma, Crítica, Dialética, do Lugar, do Lugar/Ambiente, do/no Contexto (FREIRE, 1970; COMPIANI, 2013; 2015).

No que se refere à Pedagogia Crítica do Lugar, o papel da escala atrela-se a uma concepção metodológica que envolve uma percepção das relações entre tempo e espaço, entendimento da conjuntura social numa perspectiva local-global/global-local, conhecimentos sobre diferentes realidades regionais e culturais e diferentes linguagens. Nesse artigo, será dada atenção à importância da noção de escala, conhecimentos sobre diferentes realidades regionais e diferentes linguagens, com destaque às narrativas dos alunos (COMPIANI, 2013; 2015).

Destaca-se que tanto Freire (1970) como Compiani (2013; 2015), delinearam suas práticas e concepções de educação, no sentido de promoverem a modificação dos paradigmas atuais, em que se nota o predomínio de um ensino descontextualizado. Para isso, os autores mencionados lançam mão de atividades teórico-práticas calcados no lugar de vida da comunidade escolar. Esse olhar para o local/contexto 
facilita o desenvolvimento de situações de ensino-aprendizagem que motivem crianças, uma vez que é na conexão com a comunidade local que surgem as possibilidades de mediações com o conhecimento cotidiano. Especialmente porque relacionar os conteúdos da matéria, com aspectos da comunidade local dos alunos, torna-se mais fácil de os mesmos fazerem uso de seus conhecimentos prévios. Também, ao relacionar conceitos científicos com o local e situações cotidianas, acredita-se que são criadas melhores condições de entendimento de como os alunos pensam e agem, transformando conceitos acadêmicos em ricos e ativos conceitos.

\section{PROCEDIMENTOS}

Foi analisado o Currículo do Estado São Paulo (Secretaria da Educação, 2012) e, para a escolha dos conteúdos (Situações de Aprendizagem - S.A.) apoiou-se no Currículo do Estado São Paulo (SÃO PAULO, 2012) e Caderno do Aluno, o "caderninho" (SEE/SP, 2014), material amplamente utilizado na rede estadual até o ano de 2018.

Posteriormente, foi organizado em um quadro, os conteúdos selecionados e suas respectivas competências e habilidades, também constantes no Currículo, seguidas das atividades desenvolvidas.

As atividades ocorreram com base na dialogia (exposição e contraposição das ideias entre alunos e, entre alunos e a professora), construção de narrativas (cartas) e mediação pedagógica, em que se primou pelos saberes construídos com e pelos alunos, com base em suas vivências e histórias, contempladas tanto quando em grupo, como individualmente no desenvolvimento das atividades concernentes ao projeto "Copa do Mundo de Futebol Masculino de 2018", o que tornou possível, acredita-se, identificar proximidades e/ou distanciamentos entre aquilo que os livros didáticos traziam e as ideias dos (as) alunos (as).

Demarca-se que, a professora-pesquisadora, ao auxiliar seus alunos na produção de conhecimentos que Ihes sejam significantes, que Ihes façam sentido, tem destaque o diálogo no processo de valorização dos conhecimentos e contextos de vida dos envolvidos no processo de ensino-aprendizagem (FREIRE, 1970; COMPIANI, 2013; 2015). 
E, por essas atividades se tratarem de uns dos aspectos da tese de doutoramento em curso da professora-pesquisadora, se faz pertinente destacar que a mesma trata-se de uma pesquisa "qualitativa participante", na qual o/a pesquisador (a) pode vir a alimentar ou retroalimentar os processos observados a partir do contato com as pessoas e situações no campo de coleta dos dados (FONTANA, 2005).

Por fim, para que caminhemos mais seguramente em nossas intencionalidades metodológicas explanadas, se faz necessária uma maior reflexão acerca dos conceitos de escala e contextualização, uma vez que julgamos serem eles norteadores deste estudo no que tange ao recorte documental a ser analisado; ao fenômeno em estudo; na relação do fenômeno com o contexto de vida das pessoas envolvidas no ensino-aprendizagem (alunos e professora); na espacialidade do fenômeno, dentre outros aspectos.

\section{ESCALAS NO ENSINO}

Importantes por romperem com a usual definição da escala, que seria de interpretá-la como uma fração que indica a relação entre as medidas do real e aqueles de sua representação gráfica, as considerações de Castro (1995) propõem uma revisão, fruto da necessidade teórica e conceitual da Geografia de ampliar o conceito de escala. Nesse sentido, a autora aponta a difundida ideia de uma dada inseparabilidade entre tamanho e fenômeno, o que destaca como problemático, pois os tamanhos das representações podem variar do espaço local a um planetário, o que denotaria, por consequência, representações dos fenômenos também diferenciadas.

Tem destaque, nas considerações acerca da escala, o aparato tecnológico que se pode lançar mão e, que em muito amplia a capacidade natural de representarmos e percebermos os fenômenos. No ensino de química, por exemplo, conforme Talanquer (2011), há a necessidade de se desafiar a ideia de que, o empírico ou o nível descritivo dos fenômenos observáveis e tangíveis, é limitado à escala macroscópica. Para o referido autor, isso é altamente contestável, uma vez que, nas últimas décadas, temos disponíveis tecnologias modernas que tornam as explorações na química variadas, dado que suas escalas vão do macro até a nano escala. 
No ensino de biologia, Verhoeff et al. (2008) lançaram mão de modelos para a compreensão do funcionamento celular para auxiliar na superação de estudos fragmentados sobre este tema. Para isso, partem do princípio de que os modelos proporcionem maior abstração, de modo que não somente as estruturas possam ser apreendidas mas, também, os processos e, ambos, em diferentes níveis de escalas de representação.

Ao se tratar da escala, não apenas no que tangem às suas implicações conceituais, mas também metodológicas, se faz necessária uma formação docente que caminhe nessa direção, de modo que se desenvolvam metodologias locais, do lugar, para/nas escolas e para/nas salas de aulas. Sendo assim, projetos que envolvam processos formativos de professores de escolas podem fortalecer o conceito de professor-autor, produzir metodologias que rompam como mera reprodução de conhecimentos, de processos verticalizados, já dados, e possibilitar, assim, que maior enfoque às questões cotidianas dos envolvidos, educandos e educadores, sejam dados (COMPIANI, 2018).

\section{CONTEXTUALIZAÇÃO NO ENSINO}

Outro aspecto que se julgou importante trazer, mas em um sentido de se lançar luz sobre ela, é a presença de uma educação formal notadamente descontextualizada da realidade dos envolvidos, pois em sua maioria, se baseiam em realidades que Ihe são alheias e, que por isso, promovem uma baixa relação com o espaço vivido pelos atores da comunidade escolar, em particular, de seus alunos.

Sendo assim, o que se observa nas escolas, em especial nas públicas, uma vez que estas se constituem na sua maioria, é um alunado que vê pouco sentido nas suas práticas escolares, restando-lhes, por vezes, ser um "público" resignado e comportado das falas dos professores que reproduzem os conhecimentos de terceiros (COMPIANI, 2015).

Kato e Kawasaki (2011, p. 36), ao analisarem documentos curriculares oficiais de Ciências e de Biologia, constataram que em sua maioria, os mesmos mostraram-se distantes do mundo vivido pelos alunos, "sem qualquer preocupação com os contextos que são mais próximos e significativos para os alunos e sem fazer a ponte 
entre o que se aprende na escola e o que se faz, vive e observa no dia a dia".

Para que a contextualização ocorra de um modo satisfatório nas salas de aulas, uma formação de professores calcada nesta concepção se faz necessária. Por isso, trabalhos como de Amorim et al. (2010) e o projeto Ribeirão Anhumas na Escola (COMPIANI 2013; 2015), que propõem um curso de formação continuada de professores, cujos fundamentos teóricos estruturam-se na contextualização, interdisciplinaridade e pesquisa-ação, são de extrema importância.

Nesse sentido, acreditamos que um foco em temas locais, no qual o processo de mediação do professor entre os conhecimentos escolares e cotidianos seja importante para o desenvolvimento do conhecimento pessoal das crianças. Isto porque os referidos temas locais, relacionados com o contexto e conhecimentos cotidianos dos alunos, atrai o interesse dos mesmos no processo de ensino-aprendizagem e lhes promovem desenvolvimentos qualitativos de seus conhecimentos escolares.

\section{RESULTADOS E DISCUSSÃO}

Por volta do mês de Maio de 2018, o assunto que tomava conta das conversas na sala de aula era a Copa do Mundo de Futebol. No caso dos alunos, até pela longa tradição do futebol masculino, o entusiasmo era grande, principalmente por ser comum, nas periferias dos grandes centros. Nesse sentido, era um sonho se tornar jogador de um grande time, tanto que muitos dos alunos treinavam no campo de futebol localizado ao lado da escola (Figura 1.). Contudo, dada a forte midiatização desse esporte no Brasil e no mundo, não foi diferente o engajamento das alunas durante as atividades propostas (Quadro 1).

Percebamos o local dando direção (Local-Lugar) às práticas escolares, essas formuladas entre professores e alunos a partir do vivido, do experimentado. É a cartografia latente no detalhe, na escala de detalhe, uma vez que é lugar (escola, sala de aula), contudo é também a grande escala, de pouco detalhe, mas nem por isso menos vívida, é a "Copa do Mundo" (Mundo-Ambiente); essa última relaciona-se à primeira, é a díade Lugar-Ambiente (COMPIANI, 2015). 
Figura 1. Campo de futebol próximo à E.E. Prof. Newton Oppermann

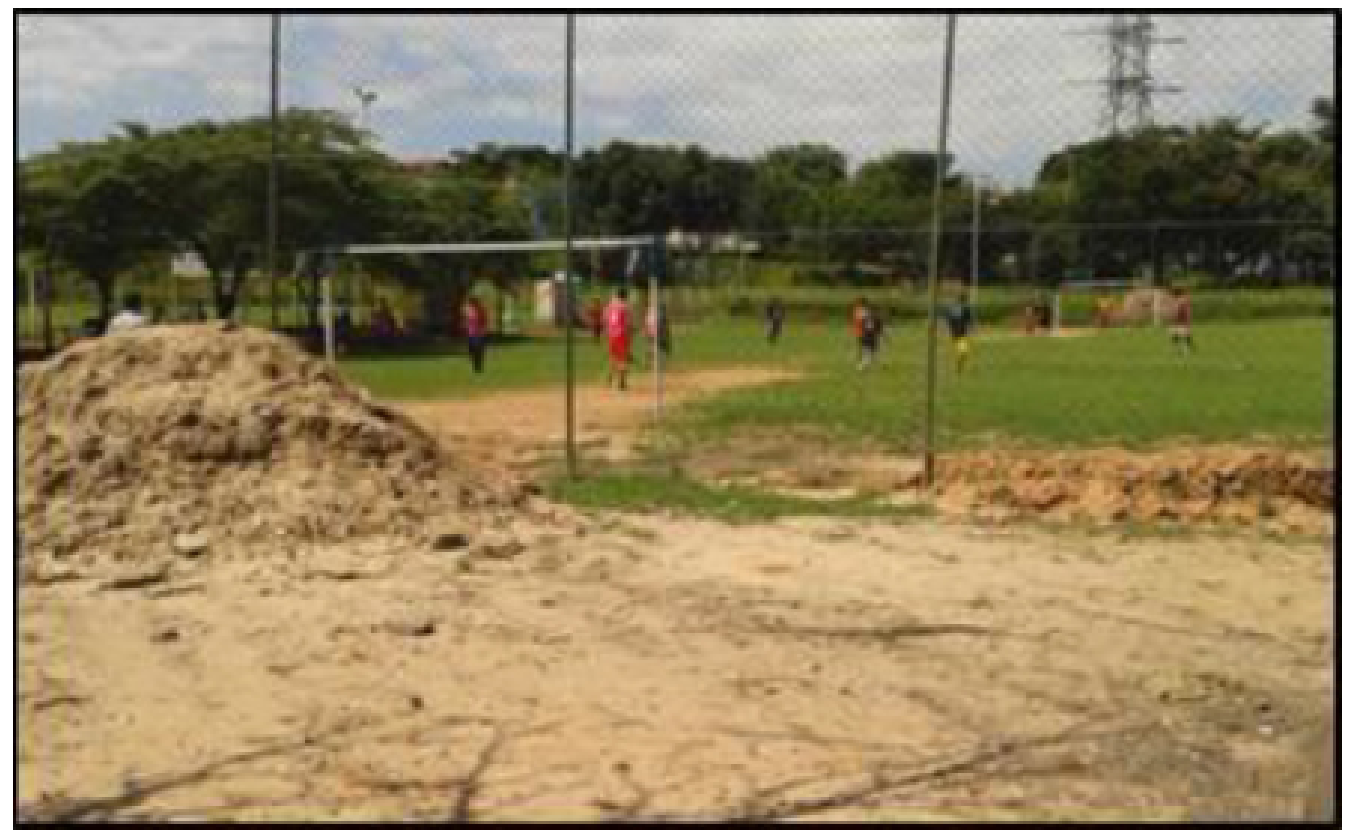

Pode-se averiguar o quanto a escala, no caminho metodológico por nós adotado, já se constitui num ferramental interessante, rumo a uma maior contextualização no processo de ensino-aprendizagem, visto que, o que costumeiramente nos deparamos, é com uma educação formal marcadamente descontextualizada da realidade dos envolvidos, o que termina por resultar em um baixo interesse dos alunos, restando-lhes "receber", educadamente, o que seus professores proferem ("educação bancária")3, na maioria das vezes, com pouca propriedade, o que outrem elaborou.

Quadro 1. Síntese de Situações de Aprendizagem (S.A.); Competências e Habilidades (C \& H) e Atividades Desenvolvidas (CURRÍCULO DO ESTADO DE SÃO PAULO, SEE-SP, 2017)

\begin{tabular}{|c|c|c|}
\hline $\begin{array}{l}\text { SITUAÇÕES DE } \\
\text { APRENDIZAGEM } \\
\text { (S.A.) }\end{array}$ & $\begin{array}{l}\text { COMPETÊNCIAS E } \\
\text { HABILIDADES (C \& H) }\end{array}$ & ATIVIDADES DESENVOLVIDAS \\
\hline $\begin{array}{c}\text { 1. As paisagens } \\
\text { da Terra }\end{array}$ & Comparar paisagens distintas. & $\begin{array}{l}\text { A geografia dos países da Copa do } \\
\text { Mundo de } 2018 \text { (Clima, vegetação, } \\
\text { relevo, população etc.). }\end{array}$ \\
\hline
\end{tabular}

3 A expressão "educação bancária", amplamente desenvolvida por Paulo Freire (1970) em sua obra Pedagogia do Oprimido, refere-se a uma relação educador-educandos de caráter marcadamente narrativo, dissertativo. Assim sendo, o educador-sujeito-narrador, leva aos "educandos-vasilhas" a mera memorização/depósito de conteúdo, a educação, desse modo, torna-se um ato de depositar.

$4 \quad$ A ordem das S.A. apresentada no Quadro 1. corresponde àquela do Currículo, contudo, as atividades desenvolvidas nas aulas não seguem essa mesma ordem. 


\begin{tabular}{|c|c|c|}
\hline $\begin{array}{l}\text { 2. O mundo e } \\
\text { as suas } \\
\text { representações }\end{array}$ & Distinção entre os mapas. & $\begin{array}{c}\text { A geografia dos países da Copa do } \\
\text { Mundo de } 2018 \\
\text { (Projeções cartográficas). }\end{array}$ \\
\hline $\begin{array}{l}\text { 3. Orientação } \\
\text { relativa: a Rosa } \\
\text { dos Ventos }\end{array}$ & $\begin{array}{l}\text { Dominar os pontos cardeais e } \\
\text { colaterais, além de aplicar } \\
\text { técnicas de orientação relativa. }\end{array}$ & $\begin{array}{l}\text { A geografia dos países da Copa do } \\
\text { Mundo de } 2018 \text { (Orientação de um } \\
\text { país em relação ao outro no mapa) e } \\
\text { a elaboração de uma carta sobre } \\
\text { o movimento aparente do Sol. }\end{array}$ \\
\hline $\begin{array}{l}\text { 4. As coordenadas } \\
\text { geográficas }\end{array}$ & $\begin{array}{c}\text { Compreender o sistema de } \\
\text { coordenadas geográficas e } \\
\text { sua utilização para determinar } \\
\text { a posição absoluta dos } \\
\text { lugares; diferenciar latitude e } \\
\text { longitude. }\end{array}$ & $\begin{array}{c}\text { A geografia dos países da Copa do } \\
\text { Mundo de } 2018 \\
\text { (Cálculo da diferença de fusos } \\
\text { horários entre os países } \\
\text { participantes). }\end{array}$ \\
\hline $\begin{array}{l}\text { 5. Os atributos dos } \\
\text { mapas }\end{array}$ & $\begin{array}{l}\text { Entender o significado da } \\
\text { legenda para a representação } \\
\text { dos fenômenos geográficos. }\end{array}$ & $\begin{array}{c}\text { A geografia dos países da Copa do } \\
\text { Mundo de } 2018 \\
\text { (Confecção da legenda). }\end{array}$ \\
\hline $\begin{array}{l}\text { 6. A Cartografia } \\
\text { Temática }\end{array}$ & $\begin{array}{l}\text { Reconhecer técnicas de repre- } \\
\text { sentação utilizadas na carto- } \\
\text { grafia temática. }\end{array}$ & $\begin{array}{c}\text { A geografia dos países da Copa do } \\
\text { Mundo de } 2018 \\
\text { (Criação de um mapa qualitativo). }\end{array}$ \\
\hline
\end{tabular}

Destaca-se que o quadro acima discrimina aquelas atividades que possibilitaram estabelecer uma relação com aspectos do cotidiano dos alunos. Em por consequência, as competências e habilidades presentes no Quadro 1 serão aquelas mais diretamente ligadas a essas atividades.

Desse modo, o trabalho "A Geografia dos países da Copa do Mundo de Futebol de 2018" tornou possível desenvolver conteúdos presentes em seis Situações de Aprendizagem, conforme se constata no Quadro 1. A sistemática adotada durante todo esse trabalho foi o de sua realização em grupos. Esses contabilizaram 8, uma vez que era o número de grupos de países a participar da competição. Assim, cada um dos 8 grupos de trabalho, somavam de 4 a 5 alunos (as), proporcionando uma interação e mediação entre eles e com a professora.

Nesse segmento de ensino, a faixa etária dos alunos (10 e 11 anos) guarda ainda um deslumbre pelas atividades que, de algum modo, possam transportá-los a uma experiência lúdica, o que, infelizmente, acaba se perdendo na medida em que 
se avança na trajetória escolar, o que pode se dar por eles mesmos (alunos/as), ou pelo fato de seus professores promoverem pouco esses momentos em suas aulas. Diante do exposto, vejamos os desdobramentos possíveis rumo a um processo de ensino-aprendizado contextualizado.

A S.A. 1 "As paisagens da Terra" (Quadro 1.) tornou possível aos alunos dos grupos de trabalho, ter uma visão geral de cada um dos países que compunha o " seu grupo da Copa" (destinado aos mesmos via sorteio). A referida S.A. cumpriu o papel de se trabalhar novamente com o conceito de paisagem, agora em numa escala de menor detalhe, uma vez que não se tratava mais de identificar se esta ou aquela paisagem do entorno da escola ou do bairro, era antrópica ou natural. Nesse sentido, é importante destacar, conforme Almeida e Passini (2010, p.12), “... que o trabalho de orientação, localização e representação deve partir do espaço próximo para o distante, porém não de forma concêntrica, mas num cotejamento permanente entre essas duas instâncias".

Assim, as C \& H de "Comparar paisagens distintas", implicaria em se ter uma visão mais geral. Para isso, os alunos pesquisaram na escala de país, características do clima, vegetação, relevo, população, moeda, língua, bandeira, dentre outros aspectos para que pudessem estabelecer, por meio da comparação, similaridades, discrepâncias, fatos curiosos, etc., uma caracterização geral dos países que compunham os respectivos "grupos da Copa".

Essa primeira etapa se findou com uma breve explanação das pesquisas realizadas pelos grupos de alunos ("grupos da copa") para todos os (as) demais alunos (as) da sala. Todo o material pesquisado pelo grupo compôs o trabalho no item de caracterização dos países, não ficando, portanto, restrito apenas a este momento de compartilhamento das informações pesquisadas.

Já "O mundo e as suas representações" (S.A. 2 - Quadro 1) possibilitou trabaIhar junto aos alunos, os diferentes tipos de projeção cartográfica (cilíndrica, cônica e plana, polar ou azimutal), o que foi realizado tendo como base o livro didático, que traziam essas projeções, além da história dos mapas, dos mapeamentos, da ciência cartográfica. Assim, introduziram-se os/as discentes nessa temática dos mapas, uma vez que a atividade a ela relacionada requereria, logo de início, uma dada habilidade com eles, os mapas. 
A partir de uma maior clareza acerca das projeções cartográficas e de como essas são comumente utilizadas para representações na escala mundial, foi proposto que desenvolvessem aquilo que consistiria a "capa" do trabalho, a sua folha de rosto. Para tanto, aos alunos foi fornecido um mapa mundi mudo (Figura 2.), no qual eles tiveram que identificar, com o auxílio de um atlas escolar, os países que compunham os seus respectivos "grupos da Copa". Etapa esta que foi geradora de diálogo, negociações, ponderações entre os alunos e a professora, a fim de se chegar corretamente aos tais países.

Figura 2. "Capa" do trabalho

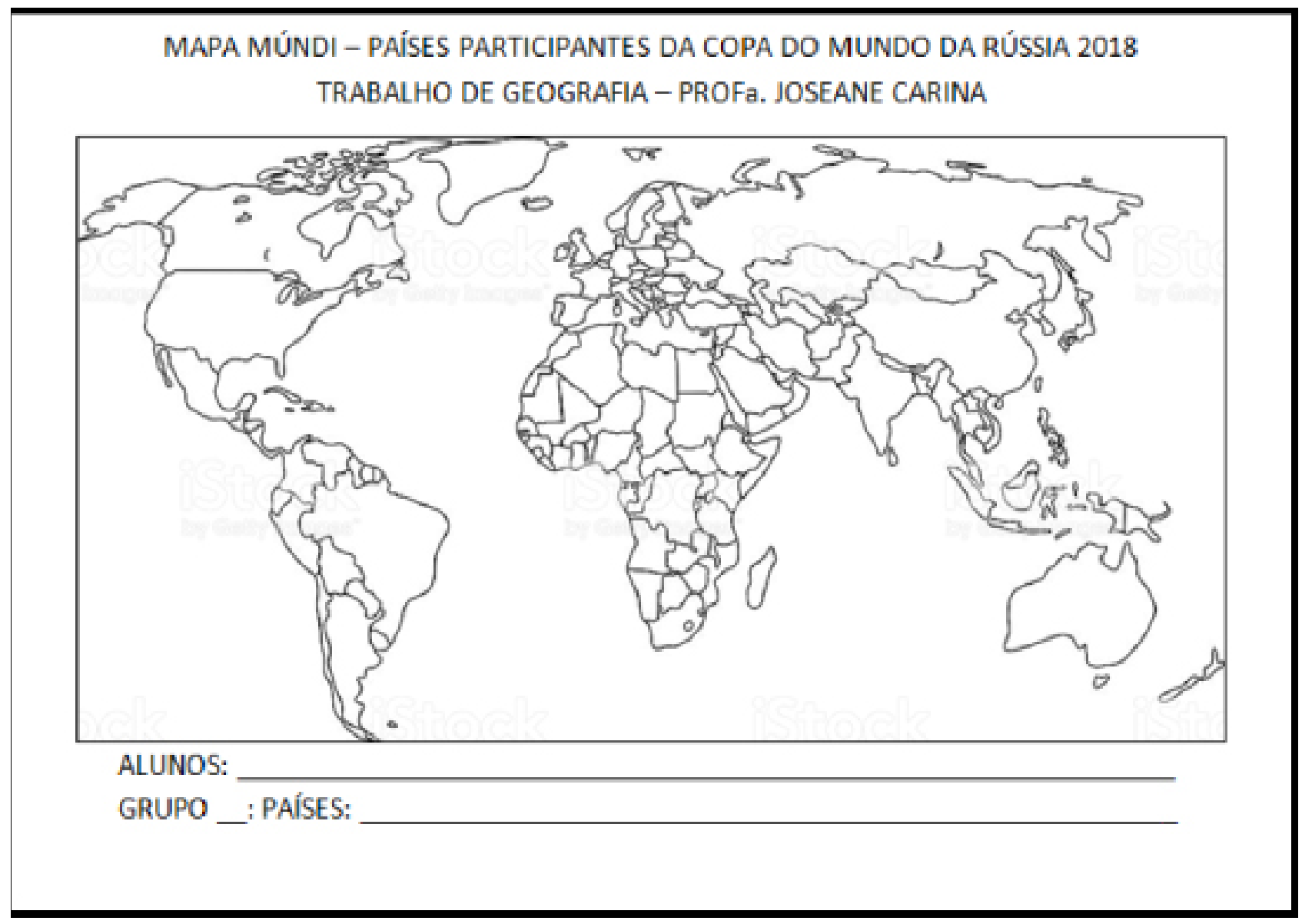

Em seguida, as S.A. 5 "Os atributos dos mapas" e S.A. 6 "A Cartografia Temática" permitiram uma compreensão concreta de como se constitui um mapa qualitativo, para isso, o mapa mundi mudo (Figura 2.) foi, pelos alunos, acrescidos de alguns atributos, como a legenda e a cor que havíamos estudado no livro didático. Dessa maneira, os alunos puderam compreender concretamente a função de uma legenda na representação de um fenômeno geográfico, no caso, o grupo dos países participantes da Copa do Mundo que, na legenda, encontram-se associados às mesmas 
cores aos quais foram estes países coloridos no mapa.

A S.A. 3 "Orientação relativa: a Rosa dos Ventos" acabou sendo retomada nesse trabalho, uma vez que havíamos trabalhado com algumas noções de direção (tendo por base o "nascer" e o pôr do sol) e os movimentos da Terra (rotação e translação) no primeiro bimestre. Contudo, neste segundo momento, os pontos cardeais e colaterais foram mais profundamente explorados ao se aplicar a técnica de orientação relativa de um país da Copa do Mundo em relação ao outro no mapa. Porém, na transição dessa atividade, desenvolvida num mapa de projeção plana para a atividade seguinte, referente aos cálculos dos fusos horários dos países durante as competições da Copa, os alunos manifestam certa dificuldade que, no diálogo com a professora, foi possível que se identificasse a necessidade reforçar a percepção da Terra enquanto uma esfera. Esse reforço foi feito, com o cuidado de se perceber que, se para os alunos ficava claro não somente a percepção/apreensão da Terra enquanto esfera, mas também, que seus movimentos de rotação e translação são determinantes para se compreender o estabelecimento dos fusos horários.

Para findar essa retomada de conteúdo e, a professora se "certificasse" de que seus alunos poderiam desenvolver melhor a atividade referente aos cálculos dos fusos horários, Ihes foi solicitado que elaborassem uma carta endereçada a algum amigo fictício, de um passado remoto que, devido às escassas informações que se tinha na época, achava que era o Sol que se movimentada e não Terra. Desse modo, a referida carta precisaria convencer esse amigo, com base nos conhecimentos adquiridos, de que "quem" se movia era a Terra, não o Sol. O resultado foi interessante, seguem alguns fragmentos transcritos dessas cartas:

Exemplo 1: "Querida Elizabeth, hoje eu descobri que na verdade é a Terra que gira em torno do Sol, eu sei que vai falar que é mentira, mas eu vou explicar, o Sol está sempre parado, mas conforme a Terra gira em torno do Sol, ela gira em torno dela mesma, isto é chamado de translação e rotação. Não sei explicar direito, então veja o desenho".

Exemplo 2: "Cara Rita estou escrevendo essa carta para te falar que não é o Sol que gira em torno da Terra. Conforme a Terra gira dá a impressão que é o Sol que está girando no céu. Esta carta é para explicar, porque você me falou que viu o Sol girando no céu. O Sol é o centro do universo e a Terra gira em torno dele. (...) Eu 
consigo saber disso através de fotos e ilustrações".

Exemplo 3: "Olá, notei que você tem um pouco de dificuldade no assunto, então fiz essa carta para ajudar. O movimento é na verdade aparente, já que na verdade é a Terra que gira em torno do Sol. (...) Esse movimento que a Terra faz em torno do Sol é bastante importante, já que ao fazer esse movimento a Terra proporciona vários tipos de temperatura, ou seja, as nossas quatro estações (...)".

Exemplo 4: "Gilberto, diariamente enxergamos o Sol 'levantar-se' num lado do horizonte e percorrer uma trajetória pelo céu e 'esconder-se' do outro lado do horizonte. Trata-se do movimento aparente do Sol: aparente pois na realidade, não é o Sol que gira ao redor da Terra, Gilberto pode acreditar no que eu estou falando, mas é a Terra que gira em torno do Sol (...)".

Diante do resultado das cartas, a atividade seguinte, a última desse trabalho "A Geografia dos países da Copa do Mundo de 2018", pode transcorrer com base em um conhecimento mais sedimentado acerca de como os fusos horários são estabelecidos. Todavia, antes de realizarmos os exercícios dos fusos horários, se fez necessária a retomada de um conteúdo elementar presente na S.A. 4 "As coordenadas geográficas", referente aos paralelos e meridianos da Terra para, na sequência, por meio dos exercícios propostos, se determinar a posição absoluta dos locais (países) por meio da latitude e longitude e, por fim, efetuar o cálculo da diferença dos fusos horários entre alguns países participantes da Copa do Mundo de 2018. Vejamos alguns exemplos das situações-problema envolvendo o cálculo dos fusos horários:

Exemplo 1: "No último sábado (16/06/2018), os argentinos jogaram contra a equipe da Islândia às 10:00 horas (hora de Brasília), calcule o horário em que os argentinos assistiram esse jogo em Buenos Aires".

Exemplo 2: "Na segunda rodada da copa, o Brasil irá jogar com a Costa Rica às 9:00 horas (hora de Brasília). O jogo será em São Petersburgo (Rússia) em qual horário?".

Exemplo 3: "O próximo jogo do Peru com a equipe da França ocorrerá na cidade russa de Ecaterimburgo às 12:00 horas (hora de Brasília). Calcule o horário que o jogo ocorrerá nessa cidade russa e nas capitais dos países em campo".

Cabe destacar que, o mapa fornecido aos alunos para compor este trabalho, não apresentava os fusos, desse modo, utilizou-se o mapa mundi presente no livro 
didático que continha os fusos horários, além de se deixar um mapa mundi grande (Planisfério) pendurado na sala para uma consulta mais facilitada, cujo tamanho permitia ver com maior nitidez as divisões dos fusos horários.

\section{CONCLUSÃO}

Este trabalho, desenvolvido junto aos alunos e alunas do $6^{\circ} \mathrm{A}$ e $\mathrm{B}$, possibilitou aos envolvidos, durante aproximadamente três meses de estudos, que diferentes conceitos, todos eles caros à Geografia, fossem trabalhados de maneira fluida, dado que se tratava de um projeto temático, cuja principal vantagem por nós elencada, foi a mais clara conexão entre os conteúdos que, por vezes, são trabalhados de modo estanque.

Observa-se que um evento de escala global, Copa do Mundo, relaciona-se com o cotidiano dos alunos de uma escola pública na cidade Campinas (Global-Local), seja pelo fato de jogarem no campo de futebol imediatamente ao lado da escola, quanto por serem bombardeados pelas diferentes formas de mídias e serem por elas altamente influenciados 5 .

Tem-se assim que a realidade dos alunos é localista e, nessa escala de trabaIho, a Geografia e a Pedagogia do Lugar tratam dos detalhes, das heterogeneidades e subjetividades, das interações dessa escala do cotidiano, da horizontalidade, mas em relação com as estruturas das disciplinas mais verticalizadas e conceituais, são estas as escalas mais generalizáveis.

Também referente à escala foi possível se trabalhar junto aos alunos a ideia de "recorte espacial", no caso, escala mundial de abrangência do fenômeno "Copa do Mundo de 2018", bem como ainda a representação do referido fenômeno em um mapa de localização dos grupos de países participantes, possibilitando o exercício de abstração do real por meio de modelos-mapas.

Outro aspecto que julgamos ser interessante na condução desse trabalho foi a exploração de outros materiais didáticos e de pesquisa para sua realização, uma

$5 \quad$ Poderíamos tecer junto aos alunos (as) inúmeras críticas acerca de um evento de escala global expropriado pela mídia, patrocinadores de grandes eventos, entretenimento de massa, esporte de massa, contudo, tal discussão se faria mais apropriada ao se trabalhar as mazelas político-ideológicas da Globalização, o que se daria, conforme o currículo, no $8^{\circ}$ Ano do Fundamental Anos Finais. 
vez que, se fossemos nos ater puramente ao livro didático e ao "caderninho", muito provavelmente o interesse dos educandos seria comprometido, o que se dá pelo fato de que, em sua maioria, esses se constituírem em materiais didáticos que pouco dialogam com realidade dos alunos e alunas.

Contudo, dadas as condições de trabalho dos professores da educação básica, em especial os que compõem a sua rede pública, de baixos salários; muitas horas de trabalho; deslocamento entre escolas; ausência de boas condições estruturais das escolas, etc., não torna possível que se trabalhe com outros materiais que não seja o livro didático, ou outro material previamente elaborado e disponibilizado nas redes de ensino. Mas acreditamos que resistir a essas agruras é uma forma de denúncia às políticas públicas educacionais massacrantes, que seguem cada vez mais aos ditames claramente de mercado, um olhar atento as atuais BNCC (2017) e Currículo Paulista (2019) não nos deixam dúvidas disso.

Diante do explanado, acreditamos que nós, professores e professoras, podemos lançar mão da lógica relacional contida na díade Lugar-Ambiente (COMPIANI, 2013; 2015), uma vez que, no dia a dia da sala de aula, ao resistirmos, ao darmos voz, lançarmos luz no que experienciamos juntamente com os educandos estaremos a dialogar, a somar forças contra aquilo que nos é (im)-posto em instâncias de Brasil e de mundo.

\section{REFERÊNCIAS}

ALMEIDA, R.D. e PASSINI, E. Y. O Espaço Geográfico: Ensino e Representação. São. Paulo: Contexto, 2010. 90p.

AMORIM, F.; SOUZA, C. P.; TRÓPIA, G. Interdisciplinaridade, contextualização e pesquisa-ação: influências de um curso de formação continuada de professores de ciências na prática docente. Atos de Pesquisa em Educação, Blumenau, v. 5, n. 2 , p. 189-208, 2010. Quadrimestral. Disponível em: https://proxy.furb.br/ojs/index.php/ atosdepesquisa/article/view/1979/1326. Acesso em: 05 jun. 2020.

CASTRO, I. E. de. O problema da escala. In: CASTRO, I. E. de; GOMES, P. C. da C.; CORREAA, R. L. (org.). Geografia: conceitos e temas. conceitos e temas. 2. ed. Rio de Janeiro: Bertrand Brasil, 2000. Cap. 4. p. 117-140. 
COMPIANI, M. Projeto Ribeirão Anhumas na Escola: fundamentos pedagógicos e educacionais. In: COMPIANI, M. (org.). Ribeirão Anhumas na Escola: projeto de formação continuada elaborando conhecimentos escolares relacionados à ciência, à sociedade e ao ambiente. Curitiba: Crv, 2013. Cap. 1. p. 11-248.

COMPIANI, M. Aprofundando a concepção de pedagogia crítica do Lugar/Ambiente. In: COMPIANI, M. (org.). Ribeirão Anhumas na Escola: pesquisa colaborativa entre a escola e universidade gerando conhecimentos contextualizados e interdisciplinares. Curitiba: Crv, 2015. Cap. 8. p. 179-202.

COMPIANI, M. Formação contínua de professores e pesquisa-ação: discussão de um programa de formação em ensino de Ciências. In: Cachapuz, A. F.; Shigunov Neto, A.; Fortunato, I. (org.). Formação inicial e continuada de professores de ciências: o que se pesquisa no Brasil, Portugal e Espanha. São Paulo: Edições Hipótese, 2018. Cap. 4. p. 97-132.

BRASIL. Base Nacional Comum Curricular (BNCC). Educação é a Base. Brasília: MEC, 2017. http://basenacionalcomum.mec.gov.br/images/BNCC_20dez_site.pdf. Acesso em: 22 de dezembro de 2017.

ESTADO DE SÃO PAULO (SEE - Secretaria Estadual de Educação). Currículo Paulista. 2019. 526p.

FREIRE, P. Pedagogia do Oprimido. Rio de Janeiro: Paz e Terra, 1970. 184 p. KATO, D. S. ; KAWASAKI, C. S. As concepções de contextualização do ensino em documentos curriculares oficiais e de professores de ciências. Ciência \& Educação (Bauru), [s.I.], v. 17, n. 1, p. 35-50, 2011. FapUNIFESP (SciELO). http://dx.doi. org/10.1590/s1516-73132011000100003.

TALANQUER, V. Macro, Submicro, and Symbolic: the many faces of the chemistry "triplet". International Journal Of Science Education, [s.I.], v. 33, n. 2, p. 179-195, 8 jan. 2010. Informa UK Limited. http://dx.doi.org/10.1080/09500690903386435.

VERHOEFF, R. P.; WAARLO, A. J.; BOERSMA, K. T.. Systems Modelling and the Development of Coherent Understanding of Cell Biology. International Journal Of Science Education, [s.I.], v. 30, n. 4, p. 543-568, 19 mar. 2008. Informa UK Limited. 


\section{INTRODUÇÃO}

Em 2009 a Escola Municipal de Ensino Fundamental - EMEF Padre Emílio Miotti foi indicada pela Secretaria Municipal de Educação de Campinas-SP para receber 500 laptops educacionais XO, doados pela One Laptop per Child Foudantion - OLPC ${ }^{2}$. O lugar de professora nesta unidade educacional durante a experiência de implementação de um laptop por aluno possibilitou uma interessante perspectiva de, não apenas vivenciar situações de ensino-aprendizagem inovadoras, mas sobretudo, refletir acerca da inserção e do uso das novas tecnologias computacionais no cotidiano escolar.

O Núcleo de Informática Aplicada à Educação (NIED) da Unicamp por meio do projeto de pesquisa " $\mathrm{XO}$ na escola e fora dela: uma proposta semio-participativa para tecnologia, educação e sociedade"s conduziu todo o processo de implementação dos laptops na escola, entre os anos de 2010 e 2012. Segundo Baranauskas (2012, p.6), docente coordenadora do projeto, este tinha como premissa desenvolver um modelo de inclusão de laptops educacionais em escolas públicas, como alternativa ao realizado em Programas Governamentais, "a partir de soluções construídas coletivamente por toda a comunidade escolar que fizessem sentido e trouxessem benefícios à todas as partes interessadas - alunos, profissionais da educação e comunidade" (BARANAUSKAS, 2012, p.5).

A partir de uma série de atividades na escola, que incluíram doze grandes oficinas de trabalho e inúmeros encontros de formação, os professores e pesquisadores do NIED-Unicamp envolveram no processo toda a comunidade escolar, sempre contando com a participação dos professores, funcionários, equipe gestora, alunos e seus familiares.

Diversos subprojetos foram implementados no processo de incorporação dos laptops XO no cotidiano escolar. Dentre eles destacamos um conjunto de oficinas ministradas por pesquisadores do NIED para alunos da EMEF, com o objetivo de formar alunos monitores, visando prepará-los para o uso do software Scratch e para a

2 Organização não governamental responsável pelo desenvolvimento e distribuição de 2,5 milhões de laptops XO de baixo custo para países pobres. Mais informações em: http://one.laptop. org/

3 Projeto financiado pelo CNPq, coordenado pela Professora Doutora Maria Cecília Calani Baranauskas, docente do Instituto de Computação e coordenadora do Núcleo de Informática Aplicada à Educação - NIED, da UNICAMP. 
participação no evento Scratch Day4. As oficinas mostraram aos alunos ferramentas e formas de pensar estruturadas pelo uso do aplicativo Scratch.

O Scratch é uma plataforma digital gratuita e de código aberto, desenvolvida pelo Massachusetts Institute of Technology - MIT que buscava "pesquisar e compreender melhor como o trabalho criativo com as tecnologias, especialmente usando bricolagem e programação, se relaciona com o processo de aprendizagem" (SOUZA, 2019, p.13). O Scratch contém uma linguagem de programação que facilita a criação de jogos, animações, narrativas interativas, além da possibilidade do compartilhamento das criações na plataforma do Scratch na web, incentivando a colaboração, o desenvolvimento da criatividade e do raciocínio lógico matemático das crianças e adolescentes.

Para o processo de ensino-aprendizagem de maneira geral, e para a Geografia em específico, é uma ferramenta poderosa ao possibilitar inúmeras estratégias que favorecem o desenvolvimento de habilidades como a observação, a seleção, a organização, a comparação, a integração e síntese de vários conceitos e informações. Os alunos sentem-se bastante motivados a vencer os desafios que são propostos.

Este artigo traz um breve histórico da introdução dos laptops no cotidiano da escola, fornecendo elementos para a discussão acerca da crescente inclusão das tecnologias computacionais na sala de aula que influenciam em maior ou menor medida as práticas pedagógicas contemporâneas.

Desta maneira, apresentaremos duas experiências na utilização de um laptop por aluno na EMEF Padre Emílio Miotti, em Campinas, a partir da experiência de utilização do Scratch, destacando que com esta linguagem de programação de computadores adequada às crianças é possível que os alunos exerçam seu protagonismo e autonomia ao exercitarem a criação de novos objetos educacionais, ou mesmo a adaptação de objetos já existentes.

Os produtos obtidos com essa atividade são exemplos de objetos de aprendizagens, que "são recursos digitais que podem ser usados, reutilizados e combinados com outros objetos para formar um ambiente de aprendizado rico e flexível" (SÁ FILHO; MACHADO, 2003). São componentes didáticos digitais que servem de

$4 \quad$ Scratch Day é uma rede mundial de encontros que ocorre uma vez por ano, no qual scratchers do mundo inteiro podem compartilhar projetos e experiências no site oficial do evento: http:// scratch.mit.edu. 
mediação e facilitação para a formação e consolidação de um saber novo. É a aprendizagem apoiada por computador, que acreditamos ter efeitos positivos na educação na medida em que auxiliam o desenvolvimento da cooperação, do raciocínio lógico e da autonomia do aluno. (SÁ FILHO; MACHADO, 2003).

\section{O USO DO COMPUTAdOR NA ESCOLA PÚBLICA, AlgumAs REFLEXÕES}

Quais são os dilemas enfrentados pela comunidade escolar na incorporação de um laptop por aluno em seu cotidiano? Muitos questionamentos surgiram, como por exemplo: Será que as ferramentas como os computadores pessoais, a internet, os smartphones, enfim, "os objetos técnico-informacionais" (SANTOS, 2006), prestam um desserviço à educação? Serão esses objetos inimigos das leituras de clássicos da literatura, do processo de formação de leitores, ou de uma aula expositiva-reflexiva?

Para Lévy (2004) os computadores são uma importante ferramenta aos processos de ensino-aprendizagem mais ativos. Afirma que as tecnologias intelectuais apoiadas pelo ciberespaço ampliam, exteriorizam e alteram muitas funções cognitivas humanas como: a memória (bancos de dados e hipertextos), a imaginação (simulações), a percepção (ambientes interativos e imersivos) e os raciocínios (inteligência artificial).

Quanto mais ativamente uma pessoa participar da aquisição de um conhecimento, mais ela irá integrar e reter aquilo que aprender. Ora, a multimídia interativa, graças à sua dimensão reticular ou não linear, favorece uma atitude exploratória, ou mesmo lúdica, face ao material a ser assimilado. É, portanto, um instrumento bem adaptado a uma pedagogia ativa.". (LEVY, 2004, p.24)

Lévy (2004, p.24) ao teorizar acerca do papel das tecnologias da informação na constituição das culturas e inteligência dos grupos argumenta que "a técnica não é boa, nem má, nem neutra, nem necessária", sendo o computador, uma ferramenta tecnológica que pode dinamizar ou atualizar as relações de aprendizagem. Para Lévy (2004) "é preciso encorajar os cidadãos a se informarem e agirem", fugindo de uma orientação anti técnica. 
Considerando que vivemos a chamada "sociedade da informação" caracterizada segundo Castells (1999), por quatro aspectos ou tendências principais: (1) acesso à informação proporcionado pelas tecnologias da informação; (2) excesso de informação; (3) mudança do paradigma educacional centrado no professor e (4) transformações perceptivo-cognitivas por parte do novo tipo de leitor, que se forma a partir das Tecnologia da Informação e Comunicação - TIC, "forma-se um leitor mais visual, que navega entre os nós da Web, construindo roteiros não lineares e não sequenciais e, que interage com as diversas mídias nela disponíveis" CASTELLS, 1999, p.. Dessa maneira o laptop pode ser usado para ampliar as condições dos alunos descobrirem e desenvolverem suas potencialidades.

No entanto, é preciso estar atento ao que Milton Santos (2006) nos diz sobre os objetos, pois estes "têm um discurso que vem de sua estrutura e revela sua funcionalidade. [...] É o discurso do uso, mas, também, o da sedução" (SANTOS, 2006, p.227). Dessa maneira, talvez seja pertinente deslocarmos a questão acerca das ferramentas ou das tecnologias em si, para focarmos as análises em quais usos faremos dos objetos e nas ações sobre e com eles. Não a partir dos discursos sedutores, mas por sua contingência e inexorável presença.

Não estamos desconsiderando nesta reflexão a questão da distribuição desigual dos objetos técnicos pelo território (SANTOS, 2006), tampouco o sistemático sucateamento das escolas públicas brasileiras, com destaque para o estado de São Paulo. No entanto, a realidade da presença massiva dos smartphones e da internet no cotidiano dos alunos dentro e fora das escolas se impõem sobre um número cada vez maior de lugares e com muita força. É preciso preparar-se e refletir sobre esta realidade.

A primeira experiência com o Scratch a ser aqui descrita é a da aplicação de um jogo de perguntas e respostas sobre as diversas fases do ciclo hidrológico na natureza que já estava pronto e disponível na plataforma Scratch na internet (http:// scratch.mit.edu). Neste momento de aproximação com esta linguagem utilizamos um recurso intitulado "remixagem", que consiste "em copiar a aplicação desenvolvida por outro usuário, modificá-la e adaptá-la de acordo com seus interesses" (SOUZA, 2019, p.14). 
A segunda experiência, considerada mais complexa e que exigiu além do domínio do conteúdo de geografia trabalhado, criatividade, persistência e raciocínio lógico, consistiu na criação, pelos alunos, de um jogo interativo que tinha como objetivo a identificação dos domínios morfoclimáticos do Brasil. Ambas as atividades foram aplicadas e desenvolvidas por alunos do sexto ano do ensino fundamental.

\section{UTILIZANDO O SCRATCH NOS ESTUDOS DAS DINÂMICAS DA NATUREZA.}

As primeiras aproximações das aulas de Geografia com o software Scratch foram feitas a partir de atividades prontas e disponíveis no repositório do próprio software na internet. Estávamos trabalhando com as turmas de $6^{\circ}$ ano sobre as diversas fases do ciclo hidrológico na natureza. Encontramos a respeito deste tema uma quantidade bastante grande de atividades na plataforma, todas muito semelhantes.

Em geral, apresentavam uma representação do ciclo da água na natureza e a tarefa do aluno consistia em nomear cada uma das etapas do ciclo, como mostram as figuras $1 \mathrm{a}$ e $1 \mathrm{~b}$ :

Figuras 1a e 1b. Representações do ciclo hidrológico em telas do Scratch em modo de apresentação.
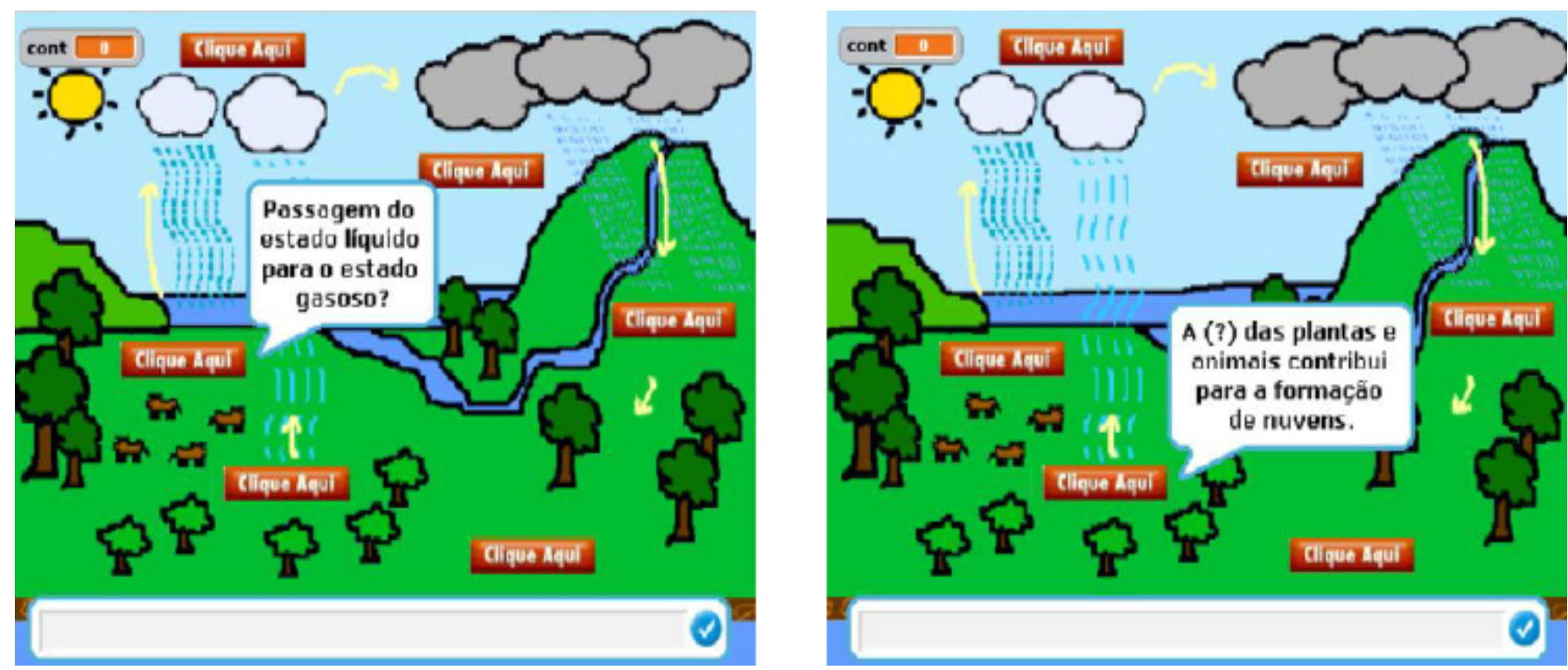

Fonte: A autora.

O Scratch também funciona como um grande repositório de pequenos softwares sobre os mais variados temas. Dentre as várias opções disponíveis na plataforma 
sobre o ciclo da água selecionamos a atividade descrita e realizamos adaptações: ao clicar no botão vermelho aparecia uma única pergunta: "o que acontece aqui?" que foi substituída pela descrição de alguns conceitos já trabalhados em aula: por exemplo, ao invés de "o que acontece aqui" substituímos por: "a (precipitação) é formada a partir da condensação da água; ao chover a água pode novamente evaporar, escoar sobre o terreno ou (infiltrar) no solo; a (evapotranspiração) das plantas e animais contribui para a formação de nuvens; passagem do estado líquido para o estado gasoso (evaporação) e etc". O que aparece entre aspas é a resposta esperada como correta.

A atividade foi pensada como um jogo. Na parte de baixo da tela há um espaço em branco para que o aluno escreva sua resposta, que é verificada pela máquina. $A$ cada resposta correta o jogador recebe um ponto, tendo direito a duas tentativas em cada uma das etapas do ciclo (botão vermelho). Se nas duas tentativas não acertar, recebe a mensagem "fim de jogo" e é obrigado a reiniciar o trajeto. A ideia é que o aluno percorra todas as etapas do ciclo hidrológico nomeando-as a partir da observação das ilustrações e da leitura das perguntas conceituais, podendo totalizar até seis pontos ao final do jogo.

A verificação imediata que o aluno recebe da máquina pode ser apontada como a principal vantagem proporcionada por atividades deste tipo. Não há necessidade de aguardar a correção feita pelo professor, gerando maior autonomia do aluno no processo de retomada dos conceitos apreendidos.

No entanto, este tipo de atividade limita-se à simples retomada e fixação dos conceitos já estudados. Não há uma participação mais ativa e criativa do aluno na construção de seu conhecimento. Diante das limitações da aplicação de uma atividade como a descrita acima, surgiu o desejo de explorarmos mais e melhor a criatividade e o raciocínio lógico de nossos alunos e as possibilidades que oferece o software Scratch para a criação de objetos de aprendizagem.

O outro tema escolhido para desenvolvermos um projeto de trabalho tendo o Scratch como ferramenta foi o dos domínios morfoclimáticos brasileiros. A diversidade e beleza das paisagens naturais brasileiras exigem um trabalho de observação, caracterização e comparação que pode ser bastante favorecido ao elegermos as fotografias como matéria prima do trabalho. 
Após uma sequência didática de estudos das interrelações entre relevo, tipos de solos, formas de vegetação e condições climático-hidrológicas e de que maneira contribuem para compor esses complexos relativamente homogêneos e extensivos: os domínios morfoclimáticos que podem ser considerados como elementos sínteses dessas interações na natureza. Finalizamos a sequência didática sobre as interrelações dos elementos da natureza com a atividade a seguir descrita.

Aos alunos coube a tarefa de buscar na internet imagens que representassem cada um dos seis grandes domínios paisagísticos e macroecológicos de nosso país, conforme definido por Aziz Ab'Saber (2003). Diante da diversidade de imagens que retornavam da busca, os alunos utilizaram critérios próprios para a escolha, tendo prevalecido o senso estético de cada um.

De posse de um acervo de pelo menos uma imagem de cada um dos domínios morfoclimáticos brasileiros, iniciou-se a discussão de como iríamos dar prosseguimento ao trabalho, pois era importante que os alunos participassem da visualização de possibilidades e da construção das propostas. O que é possível fazermos no Scratch utilizando estas imagens? Esta questão que norteou este momento do trabaIho, conforme exemplificado nas figuras $2 \mathrm{a}$ e $2 \mathrm{~b}$ adiante:

Figuras $2 \mathrm{a}$ e $2 \mathrm{~b}$. Partes do jogo interativo desenvolvido pelos alunos do $6^{\circ}$ ano $\mathrm{B}$ em 2012. Tela do Scratch em modo de apresentação.
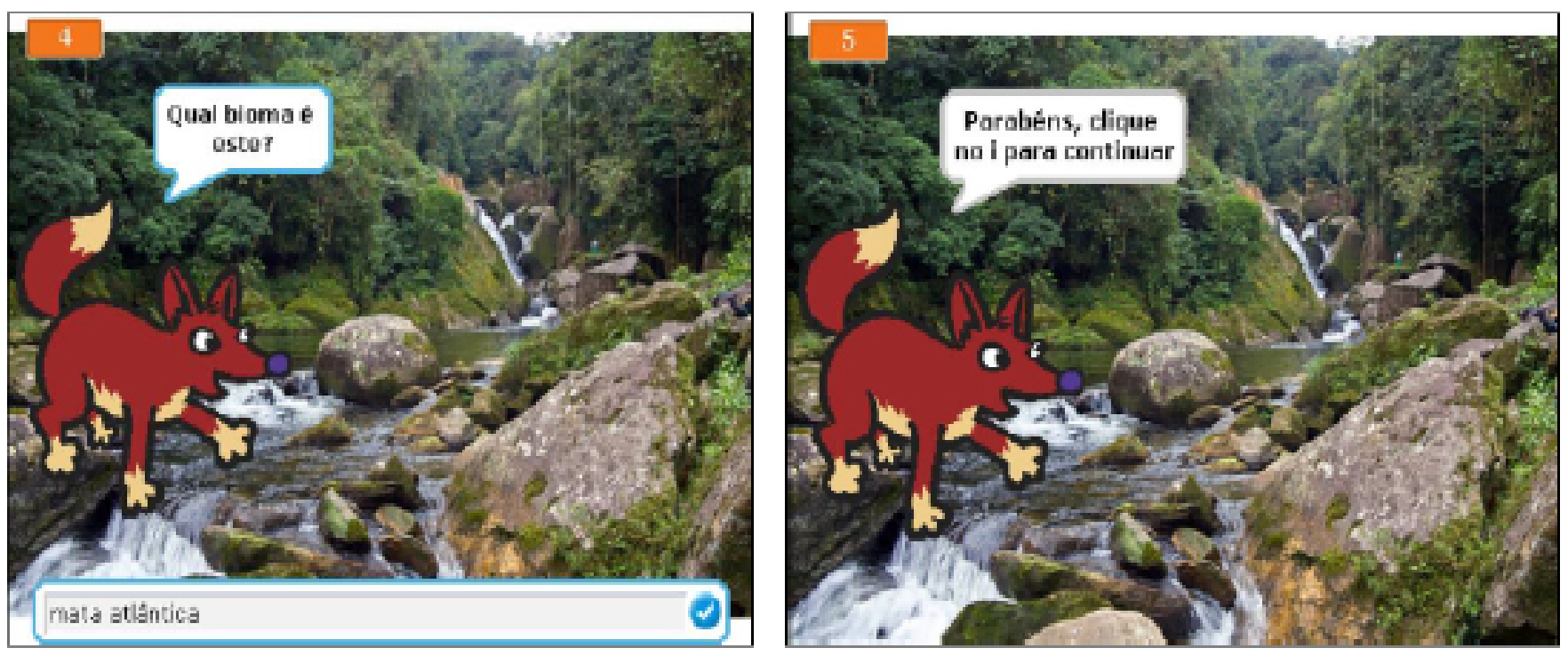

Fonte: A autora. 
As ideias dos alunos confluíram para a construção de um jogo, no qual as imagens são exibidas e o jogador é convidado a identificar o respectivo domínio morfoclimático. No entanto uma grande diversidade de resultados foi alcançada, o que reflete as diferentes maneiras como cada aluno conseguiu se apropriar e manusear esta nova ferramenta tecnológica. Cerca de $30 \%$ dos alunos, aqueles com um raciocínio lógico mais apurado, exploraram muito bem o potencial do aplicativo desenvolvendo sequências lógicas como a da figura 3a. Os demais conseguiram resultados menos ambiciosos criando jogos mais simples como na figura 3b. Mas todos estavam envolvidos e o conhecimento adquirido por um era rapidamente socializado permitindo que avançassem colaborativamente.

Figuras $3 a$ e $3 b$. Linhas de pensamento com o uso dos comandos da linguagem de programação. À direita, elaborado pela aluna Ariane, à esquerda pelo aluno Lucas, ambos do $6^{\circ} \mathrm{B}$ em 2012.
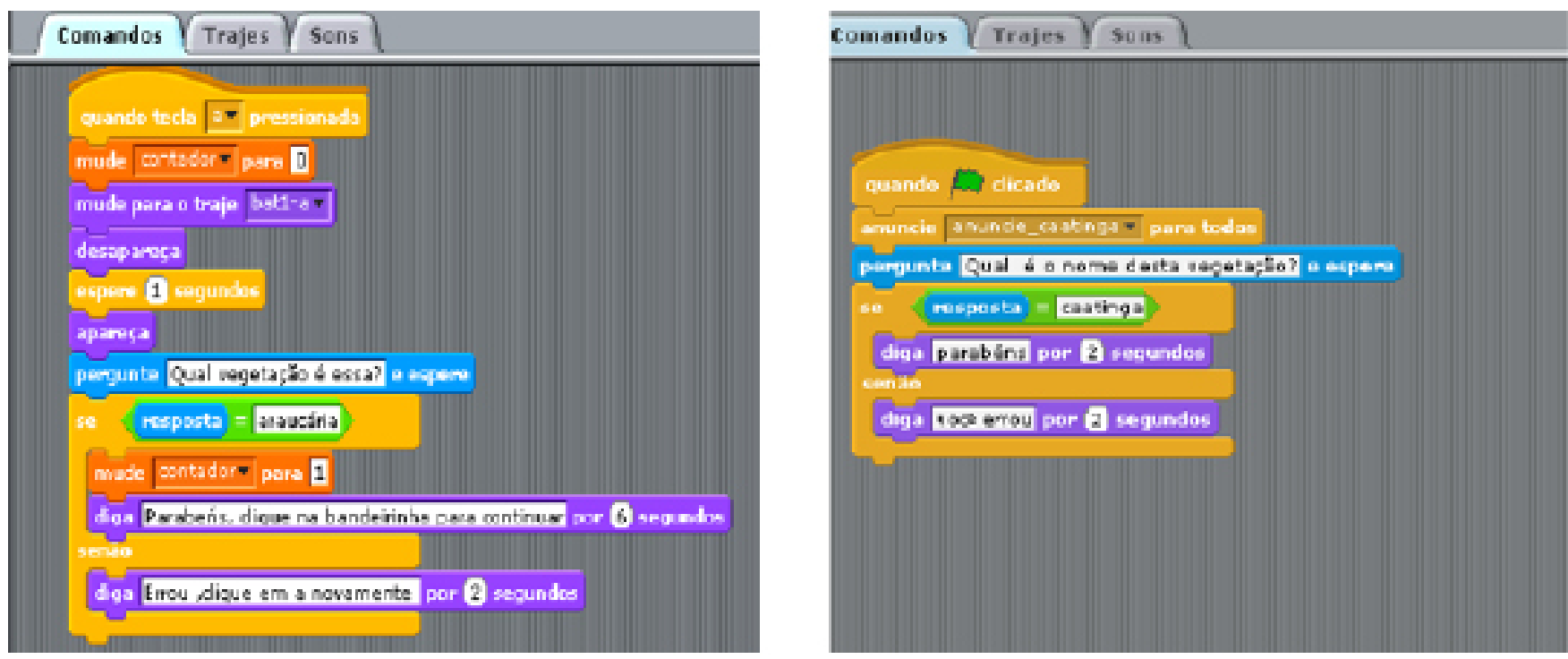

Fonte: A autora.

Os exemplos acima ilustram o caminho lógico percorrido pelos alunos na criação de um jogo interativo, no qual cada bloco representa um comando a ser executado pelo computador, sendo que estes comandos que devem ser agrupados de modo lógico pelo aluno programador.

"Como faço para mudar a minha tela? E o meu personagem, como faço para que ele faça uma pergunta? Como vou verificar se a resposta está certa ou errada? Como faço para contar e acumular pontos?" Esses são exemplos das perguntas fei- 
tas pelos alunos que os mobilizaram na tentativa de programar a máquina para executar tais comandos. A busca coletiva por superar cada um dos novos desafios que surgiam foram bastante motivadoras.

\section{CONSIDERAÇÕES FINAIS}

Para Milton Santos (2006) um grande dado do nosso tempo, refere-se ao fato de sermos, todos os dias, convocados pelas novíssimas inovações para aprender tudo de novo. "Nunca, como agora, houve tanta necessidade de um saber competente, para reinterpretar a lição dos objetos que nos cercam e das ações de que não podemos escapar". (SANTOS, 2006, p.227).

Devido às intensas e incessantes transformações sociais acreditamos ser urgente e necessária a inclusão digital das comunidades escolares com a possibilidade de vivenciar todos os dilemas que esses processos trazem, pois na aprendizagem apoiada por computador, há uma possibilidade ampliada de os alunos (re) construírem o conhecimento a partir da discussão, da reflexão e da tomada de decisões, coletivamente. A natureza da atividade desenvolvida e da interface utilizada possibilitaram a realização de um trabalho em conjunto e colaborativo.

É importante destacar que é preciso um objetivo e uma intencionalidade para o uso de um objeto educacional. Por seu caráter coletivo, interativo, a criação e o compartilhamento desses objetos na rede, apoiados pelo uso de computadores, favorecem o protagonismo e a implementação de metodologias mais ativas, desde que inseridos de maneira consciente e planejada.

Mas para que seus resultados sejam significativos e de fato realizam uma ampliação das possibilidades de desenvolvimento cognitivo e intelectual de nossos alunos a partir do acesso à tecnologia e à informação em um novo contexto de relações de ensino-aprendizagem, ainda são necessários o desenvolvimento de novas práticas pedagógicas e de mais variedades e qualidades de opções de softwares educacionais, objetos de aprendizagem e conhecimento técnico dos profissionais envolvidos no processo.

Pois muito mais importante do que a tecnologia em si é o uso que se faz dela, sendo que uma ferramenta por si só não pode transformar uma atividade. Ou então, estaremos utilizando novas ferramentas em velhas práticas, o que já se provou ser 
totalmente inócuo.

De acordo com Milton Santos (2006) quanto menos os sujeitos dominarem os segredos dos objetos técnicos "menos condições de comandar a sua própria evolução e mais dirigidas de fora tendem a ser" (SANTOS, 2006, p.227). Dessa maneira concordamos com Souza (2019) de que se o trabalho com o Scratch, ou com qualquer outra ferramenta tecnológica, for bem conduzido, pode promover, em paralelo à aprendizagem dos conteúdos, uma consciência mais crítica dos alunos frente à sua relação com a(s) tecnologia(s), para que se percebam "para além de meros consumidores de produtos tecnológicos" vislumbrando também a possibilidade da criação autônoma (SOUZA, 2019, p.11).

\section{REFERÊNCIAS}

AB `SÁBER, Aziz Nacib. Os domínios da natureza no Brasil: potencialidades paisagísticas. São Paulo: Ateliê Editorial, 2003. p.9-26.

BARANAUSKAS, Maria Cecília Calani.; MARTINS, Maria Cecília.; ASSIS, Rosângela de (orgs.). XO na escola: Construção Compartilhada de Conhecimento - Lições Aprendidas. Campinas: Editora - NIED/UNICAMP, 2012. 357p.

CASTELLS, Manuel. A sociedade em rede. São Paulo: Paz e Terra, 1999.

LÉVY, Pierre. As tecnologias da Inteligência - O futuro do pensamento na era da informática. São Paulo: Editora 34, 2004, 13a. Edição.

SÁ FILHO, Clovis Soares; MACHADO, Elian de Castro. O computador como agente transformador da educação e o papel do objeto de aprendizagem. Disponível em: http://www.abed.org.br/seminario2003/texto11.htm, acesso em 24/08/2013.

SANTOS, Milton. A Natureza do Espaço. Técnica e Tempo. Razão e Emoção. São Paulo: Edusp, 2006. 384p.

SOUZA, M. F. de.; Christine, C.S. SCRATCH: Guia Prático para aplicação na Educação Básica. Rio de Janeiro: Imperial, 2018, 78 p. 


\title{
PATRIMÔNIO AMBIENTAL E CULTURAL:
}

\section{METODOLOGIAS ATIVAS E}

\section{ESTRATÉGIAS DIDÁTICO PEDAGÓGICAS NO ENSINO DE GEOGRAFIA}

\author{
TIAGO FERNANDES RUFO \\ GILVAN CHARLES GERQUEIRA DE ARAŨJO
}
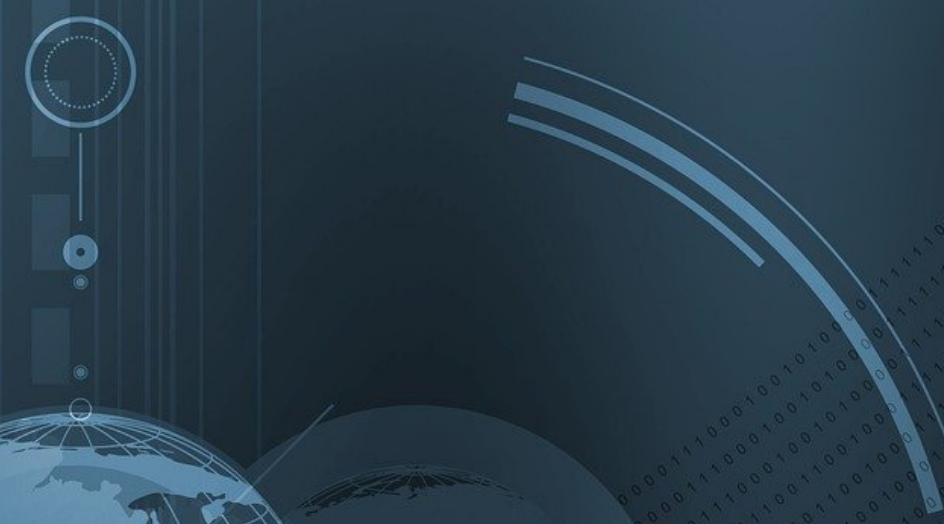

Q1-) Graetuadè em Geografia pela Universidade de Brasilia-UnB (2013), Mestre (2015) eodoutorando em Geografia pela Universidade de Brasillia (UnB) desde 2017. Atualmente é professor de Geografia na Secretaria de Estado de Educação do Distrito Federal. ORCID ID: https://orcid. org/0000-0001-9168-8653. E-mail: tiago.rufo@hotmail.com

2 Graduado em Geografia pela UNESP - Campus Rio Claro/SP (2009), Mestre em Geografia pela Universidade de Brasília (2013), Doutor em Geografia pela UNESP - Campus Rio Claro/SP (2016). Atualmente é professor de Geografia na Secretaria de Estado de Educação do Distrito Federal e realiza estágio de pós-doutoramento em Geografia pela Universidade de Săo Paulo. ORCID ID: https://orcid.org/0000-0003-4238-0139. E-mail: gcca99@gmail.com 


\section{INTRODUÇÃO}

A questão ambiental e o escopo cultural e patrimonial são perenes e necessários em nossa sociedade. Esta situação inevitavelmente se torna mais urgente ao se pensar os avanços tecnológicos e científicos vigentes desde os primeiros passos da Revolução Industrial até os mais recentes adventos da industrialização de larga escala, tais como patrimonialização de espaços e locações locais।regionais/globais, o agronegócio e o desenvolvimento da biotecnologia. Observa-se, como desdobramentos a escassez de recursos naturais por meio do uso excessivo de fontes energéticas e, também, ao mal uso e distribuição das riquezas ambientais ao redor do planeta, destinação e manejo de resíduos, como água, solos agricultáveis e acesso a bens e serviços em áreas rurais e urbanas.

Tratar sobre patrimônio cultural e política de patrimonialização é trazer para a mesma discussão pontos de vista, de ação e compreensão diferenciados, e até mesmo antagônicos, a respeito destas searas, pois trata-se de teorizar e analisar um objeto, um recorte situacional, em condição de excepcionalidade sígnica, simbólica e cultural em relação ao que o rodeia. O patrimônio fascina e causa espanto, porque guarda em si a culturalidade incrustada no limite de uma porção determinada da realidade objetiva, contendo em si, também, a diferenciação e contexto de sua alocação em tal patamar simbólico, pois o patrimônio cultural, ao chegar neste status sígnico e simbólico, passa por uma via de escolhas e decisões, amiúde, relacionadas a grupos específicos que assim o elegeram como referência à uma cultura local, regional ou global, em determinado recorte histórico.

Dessa forma, o capítulo estabelece uma discussão em torno da temática do patrimônio ambiental e cultural e propõe reflexões, caminhos metodológicos e estratégicas de operacionalização dos dois tópicos no ensino de Geografia, englobando conteúdos, temáticas e objetivos de aprendizagem que demandam relações e diálogos interdisciplinares com outros componentes curriculares e áreas do conhecimento como Sociologia, Filosofia, História, Biologia etc. Buscar o desenvolvimento de metodologias didático-pedagógicas que contemplem essa diversidade e riqueza de particularidades da patrimonialidade é um dos desafios (dis) postos no presente estudo. 
A partir deste norte, o capítulo foi desenvolvido a partir de uma revisão bibliográfica com a seleção de obras dos principais motes de iniciação para se aprofundar melhor a respeito de tais assuntos, independente da área do conhecimento de origem ou interesse iniciador da busca pelos referenciais teóricos e epistemológicos sobre a temática do patrimônio cultural e suas variações de correlações, por exemplo, nas historicidades e territorialidades que os compõem e complexificam. Em seguida, há um foco maior na seleção de autores de grandes áreas do ensino de Geografia, e que, conjuntamente, abordem e apontem caminhos possíveis a partir das metodologias ativas e operacionalização didático pedagógica do ensino da temática do patrimônio cultural e natural.

\section{O PATRIMÓNIO AMBiental E Cultural: PREsSupostos TEÓRICOS}

O patrimônio ambiental e cultural faz parte de uma grande discussão, de grande aplicabilidade (multi)transdisciplinar, e envolve frentes na educação, cultura, na economia política, programas estatais, colaborações, acordos internacionais, dentre outros. Ressalta-se, também, que a própria diversidade ambiental brasileira vai ao encontro dos esforços atuais da Educação Ambiental pelo seu aperfeiçoamento teórico e metodológico, tendo em vista a territorialidade nacional permeada por diferentes biomas e ecossistemas, aumenta ainda mais tanto a profundidade como possibilidade de encontrarmos traços diferenciados da patrimonialidade ambiental. Dos sertões nordestinos aos mineiros e do Centro-Oeste, serras e chapadas, passando pelas florestas úmidas ou campinas do sul, cada ponto do território nacional possibilidades de encontrarmos e eligimos a patrimonialidade geoambiental no Brasil.

Autores como Luckesi (1994), Carvalho (2004) e Meyer (1991) trabalham com a temática educacional no geral e, no círculo ambiental da educação em particular, temos Loureiro (2003), Viégas (2010) e Henriques et. al (2007) que, recentemente, tem contribuído para qualificação deste debate, em diferentes alocações de suas áreas de especificidade. Como recorte ilustrativo destas referências, Loureiro (2003) disserta sobre a Educação Ambiental:

Quando se fala em Educação Ambiental, logo se imagina que esta é intrinsecamente transformadora, por ser uma inovação educativa recente que questiona o que é qualidade de vida, reflete sobre a ética ecológica e amplia o 
conceito de ambiente para além dos aspectos físico-biológicos. Contudo, isto não é uma "verdade automática". Em termos conceituais, transformar é uma palavra que permite várias ênfases: transmutar, converter, alterar, mudar de domínio, mudar de forma, transfigurar. Transformação ocorre no processo de realização da vida, podendo implicar diferentes níveis de alteração. Pensado desta forma, é um conceito que se refere ao reconstruir o conteúdo que dá a identidade de algo, ou seja, é o que faz com que, em um momento de "desconforto", seja possível se encontrar uma alternativa coerente com certos princípios e valores de um determinado grupo ou indivíduo por meios previstos, ou não, inicialmente. (LOUREIRO, 2003, p. 37-38)

Assim, há a consideração o fator transformador da Educação Ambiental, em especial por esta se situar entre núcleos de diferentes complexidades, envolvendo questões econômicas, de sustentabilidade, políticas públicas e culturais, etc. Moreira (2011) destaca que as temáticas que envolvem a educação ambiental carregam inquietações e preocupações para a sociedade, pois envolvem o debate das interações espaciais das problemáticas ambientais atuais, tais como a poluição dos rios e solos pelos agrotóxicos. Segundo Moura, Meireles e Texeira (2015),

A implantação das práticas de Educação Ambiental subsidiadas pelos conhecimentos de Geografia, possibilita uma renovação nos diálogos no ambiente escolar, permitindo aos alunos refletirem criticamente e transformarem a realidade a partir da compreensão dos fenômenos e na intervenção dos problemas socioambientais. (MOURA; MEIRELES; TEXEIRA, 2015)

No mesmo sentido, citando Lucy Sauvé, Henriques et. al. (2007) nos expõe três grandes eixos da Educação Ambiental:

- Educação sobre o meio ambiente: trata-se da aquisição de conhecimentos e habilidades relativos à interação com o ambiente, que está baseada na transmissão de fatos, conteúdos e conceitos, onde o meio ambiente se torna um objeto de aprendizado;

- Educação no meio ambiente: também conhecido como educação ao ar livre, corresponde a uma estratégia pedagógica onde se procura aprender através do contato com a natureza ou com o contexto biofísico e sociocultural do entorno da escola ou comunidade. O meio ambiente provê o aprendizado experimental, tornando-se um meio de aprendizado;

- Educação para o meio ambiente: processo através do qual se busca o engajamento ativo do educando que aprende a resolver e prevenir os problemas ambientais. O meio ambiente se torna uma meta do aprendizado. (HENRIQUES, et. al, 2007, p. 17) 
o entendimento sobre os bens naturais, sua conservação3, a educação para o meio ambiente, e todas as demais questões mediatas e correlatas, como pode ser observado em orientações da Unesco (2017), conforme segue:

Os bens naturais devem:

I. ser exemplos excepcionais representativos dos diferentes períodos da história da Terra, incluindo o registro da evolução, dos processos geológicos significativos em curso, do desenvolvimento das formas terrestres ou de elementos geomórficos e fisiográficos significativos, ou

II. ser exemplos excepcionais que representem processos ecológicos e biológicos significativos para a evolução e o desenvolvimento de ecossistemas terrestres, costeiros, marítimos e de água doce e de comunidades de plantas e animais, ou

III. conter fenômenos naturais extraordinários ou áreas de uma beleza natural e uma importância estética excepcionais, ou

IV. conter os habitats naturais mais importantes e mais representativos para a conservação in situ da diversidade biológica, incluindo aqueles que abrigam espécies ameaçadas que possuam um valor universal excepcional do ponto de vista da ciência ou da conservação.

Também são critérios importantes a proteção, a administração e a integridade do sítio.

Os sítios mistos têm, ao mesmo tempo, excepcional valor natural e cultural. Desde 1992, interações significativas entre o homem e o meio natural têm sido reconhecidas como paisagens culturais. (UNESCO, 2017, p. sln)

Apesar da Geografia Tradicional sofrer severas críticas no aspecto teórico, ela ainda é bastante difundida por instituições e professores. Ainda impera na sociedade e em parte dos alunos e professores a visão da Geografia como disciplina decorativa e descritiva (MENEGUZZO; MENEGUZZO, 2013).

Nesse caso, as temáticas da educação patrimonial e ambiental são pouco difundidas nos espaços de ensino e aprendizagem e leva-nos a crer que, quando abordadas, são trabalhadas de forma tradicional. Segundo Meneguzzo e Meneguzzo (2013), a Geografia do país só veio se preocupar com a educação ambiental a partir da década de 1990 e

Fatores como a promulgação da Constituição Federal em 1988 atrelada ao evento da $2^{\mathrm{a}}$ Conferência das Nações Unidas para o Meio Ambiente (Rio 92), com consequente divulgação da Agenda 21, a publicação dos Parâmetros

3 Iniciativas como o Rio +20 , e o projeto Monumenta são bons exemplos desta movimentação, de diferentes alcances em suas proposições e propostas, ambientais e patrimoniais. 
Curriculares Nacionais de Geografia (1998), dos Parâmetros que tratam dos temas transversais e da Lei $n^{\circ}$ 9.795/99 certamente foram os pilares para a apreensão da EA pela Geografia e demais disciplinas. (MENEGUZZO; MENEGUZZO, 2013, p.14-15)

A Lei 9.795 de 27 de abril de 1999 (Política Nacional de Educação Ambiental), regulamentada pelo Decreto $\mathrm{n}^{\circ} 4.281$ de junho de 2002, passa a considerar, além de outros órgãos, as instituições de ensino públicas e privadas do sistema de ensino e torna obrigatório a educação ambiental no ensino formal, sendo o único país da América Latina com uma política nacional a respeito. Apesar disso, ainda é incipiente em decorrência de ações fracas, desprezo e atitudes pessimistas por parte dos currículos escolares, professores e gestores escolares (MENEGUZZO; MENEGUZZO, 2013; MOURA; MEIRELES; TEXEIRA, 2015).

Apesar disso, Meneguzzo e Meneguzzo (2013) abordam a insuficiência de uma política do Estado através de políticas públicas eficazes em torno da educação ambiental. Já Liberalesso (2013), aborda que a educação patrimonial não deve ser tarefa exclusiva do professor e da escola, como também do Estado e dos agentes privados, inclusive no processo de formação dos professores em relação aos aspectos ligados ao patrimônio cultural.

$\mathrm{Na}$ esfera da educação ambiental, os problemas ambientais devem o foco das discussões, pois são problemáticas histórico estruturais não dissociadas do caráter social. A Educação Ambiental deve ser tratada como um tema transversal, capaz de unir e relacionar e dialogar diferentes áreas do conhecimento e temáticas variadas (MOURA; MEIRELES; TEXEIRA, 2015).

Os Parâmetros Curriculares Nacionais (PCNs), a partir de 1995, consideraram o tema Meio Ambiente como temática transversal, ou seja, uma área relacionada a diferentes campos do conhecimento e que não deve ficar restrita ao ambiente escolar. Assim, a educação ambiental no âmbito da Geografia deve ser orientada para a gestão do espaço e transformação de práticas atuais danosas ao meio ambiente e à sociedade (MOREIRA, 2011).

Quanto à Educação Patrimonial, há um aumento das produções e referências, como as publicações de Horta (1999; 2000), Iphan (2014) e Lemos (1981). As colocações destes autores e instituições alocam-se no sentido de levar uma compreensão das questões envolvendo o patrimônio, o meio ambiente e a cultura. Estes são 
eixos, a partir dos quais, se estruturam e desenvolvem teorizações, metodologias, estratégias, trocas de ideais, refutações e formulações de novos rumos para a relação entre a educação e temas de transversalidade que perpassam o ensino e a aprendizagem. Estes são os pilares levantados pelo Instituto do Patrimônio Histórico e Artístico (IPHAN):

É imprescindível que toda ação educativa assegure a participação da comunidade na formulação, implementação e execução das atividades propostas. O que se almeja é a construção coletiva do conhecimento, identificando a comunidade como produtora de saberes que reconhece suas referências culturais inseridas em contextos de significados associados à memória social do local. (IPHAN, 2014, p. 20)

$E$, de igual maneira, estes eixos envolvem-se com as recomendações internacionais, também da UNESCO (2017), sobre o olhar que devemos ter diante do patrimônio cultural, sua conservação, o primado da educação para a cultura de valorização patrimonial e, mais do que isto, a busca ao elo que leva a cultura ao meio, o ser humano aos recursos naturais, os biomas de um país às suas comunidades urbanas e construções históricas, enfim, fazendo com que o patrimônio seja um só, humano:

Os bens culturais devem:

II. representar uma obra-prima do gênio criativo humano, ou

II. ser a manifestação de um intercâmbio considerável de valores humanos durante um determinado período ou em uma área cultural específica, no desenvolvimento da arquitetura, das artes monumentais, de planejamento urbano ou de paisagismo, ou

III. aportar um testemunho único ou excepcional de uma tradição cultural ou de uma civilização ainda viva ou que tenha desaparecido, ou

IV. ser um exemplo excepcional de um tipo de edifício ou de conjunto arquitetônico ou tecnológico, ou de paisagem que ilustre uma ou várias etapas significativas da história da humanidade, ou

V. constituir um exemplo excepcional de habitat ou estabelecimento humano tradicional ou do uso da terra, que seja representativo de uma cultura ou de culturas, especialmente as que tenham se tornado vulneráveis por efeitos de mudanças irreversíveis, ou

VI. estar associados diretamente ou tangivelmente a acontecimentos ou tradições vivas, com idéias ou crenças, ou com obras artísticas ou literárias de significado universal excepcional (o Comitê considera que este critério não deve justificar a inscrição na Lista, salvo em circunstâncias excepcionais e na aplicação conjunta com outros critérios culturais ou naturais).

É igualmente importante o critério da autenticidade do sítio e a forma pela qual ele esteja protegido e administrado. (UNESCO, 2017, p. sin) 
Portanto, a relação do ser humano com a natureza é una e indissociável, por esta razão, as recomendações, diretrizes e prerrogativas da UNESCO (2017), juntamente com outras orientações e produções de eventos e discussões em vigência, se fazem tão indispensáveis, pois é somente com a união destes lados, o social e o natural, o humano e o físico, o ambiental e o cultural, que chegaremos à uma harmonia em nossa vivência diária com o meio.

A educação patrimonial deve ser considerada um processo permanente e direcionado aos elementos do patrimônio cultural e tem como objetivo contribuir para que a sociedade entenda a importância dos elementos culturais da sua comunidade e que isso impulsione atos de preservação e conservação dos bens culturais (HORTA; GRUNBERG; MONTEIRO, 1999; CASTRO, 2006). É a partir da educação patrimonial, que há o fortalecimento de ideais de pertencimento, respeito e compressão das diferentes formas e manifestações culturais.

A Geografia escolar necessita de métodos integrados, dinâmicos, com teor de criticidade e pautado na interdisciplinaridade (MOURA; MEIRELES; TEXEIRA, 2015) - portanto, a Geografia escolar deve ser caracterizada por práticas pedagógicas que proporcionem a construção de conhecimentos, associações e atuação prática dos estudantes. Nesse caso, a próxima seção poderá fornecer "pistas" e caminhos possíveis nesse sentido.

\section{METODOLOGIASATIVAS EESTRATÉGIAS DIDÁTICO PEDAGÓGICAS PARA A EDUCAÇÃo PATRIMONIAL E AMBIENTAL}

O ensino de Geografia deve ser construído de forma com que o aluno se sinta atraído pela metodologia do professor, com a utilização de variados recursos, métodos e estratégias didático pedagógicas, como mapas, os recursos tecnológicos, aulas de campo, entre outras (MOURA; MEIRELES; TEXEIRA, 2015). Importante frisar que há inúmeras dificuldades para trabalhar as temáticas referentes ao patrimônio cultural e ambiental: a falta de tempo e de bons materiais, como os livros didáticos, que em sua maioria pouco enriquecem e trabalham as temáticas de forma simplificada (LIBERALESSO, 2013). Os entraves acabam por intensificar o desinteresse em trabalhar tais temáticas em sala de aula.

Especificamente, o patrimônio cultural ainda é taxado como assunto restrito 
à História. Entretanto, trata-se de uma temática de cunho interdisciplinar. Muitos professores não se arriscam em temáticas inovadoras pelo seu perfil tradicional e, aqueles que encaram o desafio, muitas vezes são mal vistos dentro do ambiente de trabalho (LIBERALESSO, 2013). Trabalhar com patrimônio e meio ambiente ainda é um grande desafio, pois sofrem questionamentos até dos pais e/ou responsáveis dos alunos, que não enxergam as temáticas com a devida seriedade.

A educação patrimonial contribui de forma significante para a formação de estudantes e indivíduos com maior capacidade de compreensão e percepção do seu espaço, com tendências de maior valorização do tempo passado e do presente. Dessa forma, eleva-se as chances do despertar de uma consciência preservacionista (LIBERALESSO, 2013).

Assim, o processo de construção da educação ambiental e patrimonial, no âmbito escolar deve priorizar a criatividade e os aspectos democráticos que propiciem o engajamento dos estudantes nas temáticas atreladas e que alavanquem o processo de formação da cidadania (AIRES; BASTOS, 2011; CASTRO, 2006). Para isso, a utilização de diversas fontes de conhecimento através de variados materiais, estratégias e instrumentos que fortaleçam a prática pedagógica em Geografia, contribuirão para que os alunos percebam o viés social e natural presente no mundo (VLACH, 2003).

Segundo Horta, Grunberg e Monteiro (1999)

A Educação Patrimonial é um instrumento de "alfabetização cultural" que possibilita ao indivíduo fazer a leitura do mundo que o rodeia, levando-o à compreensão do universo sociocultural e da trajetória histórico-temporal em que está inserido. Este processo leva ao reforço da autoestima dos indivíduos e comunidades e à valorização da cultura brasileira, compreendida como múltipla e plural. (HORTA; GRUNBERG; MONTEIRO; 1999, p.4)

Torna-se importante, portanto, que o professor, no início de um ciclo em uma instituição de ensino, perceba, caracterize e interprete a realidade social, econômica, cultural e ambiental que a escola e os alunos estão inseridos. Esse passo é muito importante para traçar estratégias ao longo do ano, sobretudo em relação ao trabalho das temáticas de educação ambiental e patrimonial, pois, ambas dependem sobremaneira do contexto local. Pressupostos defendidos por Kaercher (2004), que aponta a necessidade da Geografia integrar o cotidiano do aluno, tendo como intuito o 
estímulo aos questionamentos, espantos, conexão de ideais, conceitos e processos.

É a partir desta observação, que o professor definirá se a escola possui, por exemplo, espaços para a construção de projetos de hortas para cultivo de leguminosas, verduras, frutas e plantas variadas, a depender do objetivo. É também a partir disso que o professor definirá parques, museus, áreas verdes ou afins que tenham a possibilidade de visitação ou o estabelecimento de um trabalho contínuo ao longo do ano. Na esfera cultural, é essencial a identificação de festas populares, manifestações religiosas, características da culinária, além dos padrões de vestimentas, de estilos musicais, entre outros. É importante iniciar os passos na educação patrimonial a partir de pequenos e valiosos detalhes da vida da população local que irão determinar o que de fato precisa ser valorizado e preservado no âmbito local (LIBERALESSO, 2013).

O segundo passo éa identificação dos recursos disponíveis, como disponibilidade de transporte para descolamento dos alunos, além de materiais e recursos como aparelhos tecnológicos, dentre eles notebook, projetores, som, microfone, etc.

No entanto, nada disso é possível sem o estabelecimento de parcerias dentro e fora da escola. Nesse caso, é essencial conhecer a sua equipe de trabalho, com o objetivo de promoção de parcerias em projetos e iniciativas de educação ambiental e patrimonial, incluindo também os profissionais do corpo administrativo da escola. Segundo Liberalesso (2013), as parcerias com agentes externos à escola, como entidades culturais, é uma necessidade evidente, com abertura também para a comunidade local para participação de eventos culturais na escola.

Práticas reflexivas, atividades e visitações a museus, locais e instituições que trabalhem com artesanato, como de cerâmica, além da construção de maquetes são algumas das atividades que podem ser utilizadas na educação patrimonial (JOVINO; CERQUEIRA JUNIOR, 2018). Silva (2007) aponta a necessidade de utilização de materiais e estratégias caracterizadas pelo teor de ludicidade, como o uso de quebra cabeças, obras literárias, figuras, imagens, construção de gibis e história em quadrinhos, musicalização e elaboração de peças teatrais. Tais estratégias revelamse fundamentais no processo de construção da educação patrimonial e ambiental.

A exploração dos centros históricos presentes em muitas cidades brasileiras também é um bom caminho para o aprendizado do patrimônio cultural, pois permite 
que os alunos e professores identifiquem as transformações ao longo do tempo. A partir dessa estratégia, é possível, por exemplo, que se aprenda mais sobre a história de determinadas comunidades ou bairros, com a identificação de problemas no meio ambiente e transformações da natureza, aliando educação patrimonial à educação ambiental. A partir disso, é possível desenvolver mapas mentais, exercícios de comparação e jogos de simulação (com situações problemas) (HORTA; GRUNBERG; MONTEIRO, 1999).

Liberalesso (2013) indica a utilização de recursos áudio visuais, como vídeos e imagens, com posterior confecção de jogos ou atividades lúdicas que envolvam, por exemplo, fatos históricos da comunidade local, com o desenvolvimento de atividades de levantamento e pesquisa sobre as heranças culturais dos alunos e passado familiar. Entretanto, a mera reprodução de imagens e ilustrações em sala revela-se insuficiente para a interpretação integral dos objetos culturais, portanto, explorar esses objetos dentro e fora da sala de aula é passo fundamental (HORTA; GRUMBERG; MONTEIRO, 1999).

Vlach (2003) reforça que o professor é sempre o mediador entre o conhecimento e os alunos, sendo assim, a utilização dos variados recursos tecnológicos ou de estratégias criativas, não elimina o papel de sua atuação e intervenção em sala de aula. Surmacz e Leme (2015), apontam que o professor é sempre o condutor do caminho metodológico para alcance do êxito no processo de ensino e aprendizagem dos fenômenos, incluindo as questões ambientais e culturais.

As atividades devem ter como objetivo que os alunos identifiquem bens a serem preservados dentro de sua comunidade. Posteriormente, pode-se planejar trabalhos de campo nos lugares ou bens patrimoniais escolhidos, com a sistematização do conhecimento construído através de textos, resenhas ou debates. É possível também o desenvolvimento de entrevistas planejadas com agentes envolvidos com o patrimônio cultural selecionado, com o objetivo de identificar o modo de vida e as particularidades envolvidas nessa relação (LIBERALESSO, 2013).

Trabalhos com colagens, quebra cabeças, desenhos, artesanato com utilização de barro, podem também ser bons caminhos para tratar do patrimônio cultural (LIBERALESSO, 2013). Atividades externas como saídas de campo em 
ruas, museus e espaços variados da cidade ou zona rural (áreas verdes, praças) também são boas estratégias. É preciso, logicamente, um planejamento adequado e construção de parcerias, assim como o resguardo em relação à autorização dos pais e/ou responsáveis, além da presença de profissionais de primeiros socorros (bombeiros, brigadistas, etc).

Além do planejamento logístico, há necessidade de uma boa definição dos objetivos e metas nas atividades externas, com definição dos temas e aspectos a serem interpretados e investigados. É importante seguir as etapas metodológicas: 1) Observação; 2) Registro; 3) Exploração; 4) Apropriação. O primeiro passo diz respeito ao reconhecimento do objeto e podem ser utilizadas estratégias como anotações, comparações, jogos, etc. O segundo passo é focado na fixação do conhecimento a partir da análise com a possibilidade de uso de desenhos, escrita, fotografias e confecção de mapas. O terceiro passo é o momento do desenvolvimento da capacidade crítica e de interpretação dos reais significados, com utilização de hipóteses, avaliações, pesquisas e entrevistas. O último passo é o de aproximação afetiva com o objetivo, ou seja, da valorização do significado, com utilização possível de dramatizações, pintura, música, poesia e filmes (HORTA; GRUNBERG; MONTEIRO, 1999).

Do ponto de vista pedagógico, de estratégias e recursos didáticos, é importante que o professor instigue seus alunos ao olhar atento, investigativo e detalhado sobre as características dos lugares visitados. Para isso, o professor pode autorizar o uso dos celulares para registros fotográficos para futura apresentação e contextualização por parte dos alunos (LIBERALESSO, 2013). Atividades que demandam a produção de fotografias por parte dos alunos, com uso de câmeras ou celulares, devem ter definição clara dos objetivos e com possibilidade de exposição do trabalho (HORTA; GRUNBERG; MONTEIRO, 1999).

Um importante aliado dos trabalhos de campo é a produção das chamadas folhas didáticas, que segundo Horta, Grunberg e Monteiro (1999), são importantes para orientação dos alunos no processo de descoberta dos espaços, assim como na percepção, análise e comparação. Nessa estratégia, o professor pode utilizar variados materiais de apoio, como jogos, quebra cabeças e palavras cruzadas. 
Castro (2006) defende a educação patrimonial como meio para impulsionar e contribuir para o turismo cultural em determinados lugares e para que, como contrapartida, o turismo contribua para a preservação, manutenção e valorização dos bens culturais. O turismo cultural possibilita o resgate do passado, da história, costumes, tradições e hábitos culturais de uma comunidade. O professor valer-se dessa estratégia como meio para planejar suas saídas de campo ou atividades externas planejadas para o ano letivo.

A ausência de museus e parques, no caso de pequenos municípios, não inviabiliza o trabalho das questões culturais, pois há a possibilidade de utilização da realidade local relacionada à memória, identidade, artesanato, comidas típicas e singularidades culturais da região, pois segundo Castro (2006), o conceito de patrimônio cultural diz respeito aos elementos e bens culturais que tenham significado e valor para determinados comunidades, grupos ou para a humidade. Portanto, o patrimônio cultural vai além da chancela de órgãos ou entidades oficiais atreladas à temática (HORTA, GRUNBERG E MONTEIRO, 1999).

Nesse aspecto, a utilização da realidade cultural local poderá contribuir para a construção de conhecimentos significativos para os estudantes, pois, para Surmacz e Leme (2015), os conhecimentos geográficos devem obrigatoriamente fazer sentido para a vida dos estudantes e de sua comunidade. Sendo assim, o aluno pode tornarse sujeito do conhecimento através da compreensão da sua realidade local e contexto espacial, como defende Cavalcanti (2011).

A educação ambiental deve estar atrelada à construção de conhecimentos aliados à prática, como em visitações, saídas de campo e turismo cultural, dessa forma, as ações não se tornam vazias e reduzidas apenas ao ato em si de ver, sentir, perceber o meio ambiente. Mais do que isso, o aluno deve ser estimulado a fazer associações e contextualizações com sua realidade, o instigando a promover ações seguras, pensadas e sustentáveis no meio ambiente. Assim, o aluno deve ser instigado a entender que ele é parte da natureza e que a mesma não é algo estranho e distante de sua realidade, mesmo aqueles estudantes residentes em áreas altamente urbanizadas. 
Utilizar as demandas e complexidades da realidade contemporânea a favor das metodologias ativas da Educação Patrimonial torna-se um meio pelo qual podemos explorar ainda mais as possibilidades de aplicação dessas práticas no cotidiano escolar. O intra e extraclasse são mutuamente beneficiados, a diversificação dos recursos didáticos também é incrementada pelas camadas de singularizações possíveis de serem extraídas dos aspectos históricos, econômicos, filosóficos, ambientais do patrimônio. Em outras palavras, o signo e símbolo patrimonial possui uma ponte de extrema riqueza temática passível de ser explorada pelo ensino de Geografia por meio das metodologias ativas.

A utilização de materiais e recursos naturais pode favorecer, por exemplo, aqueles professores que se sintam desconfortáveis ou sem recursos para as saídas de campo, visitações e afins. Alguns materiais, como mudas de árvores e tipos de rochas e solo, podem ser levados para o ambiente de sala de aula, com isso, permite-se que o aluno observe, diferencie, sinta e toque nos materiais. No processo de construção da educação patrimonial, Horta, Grunberg e Monteiro (1999) consideram essencial a exploração dos objetos reais como fonte de informação, como as edificações ou objetos ligados ao artesanato local.

Outra possibilidade destacada por Moura, Meireles e Texeira (2015) para se trabalhar com educação ambiental, e que também se aplica a questão cultural, está na utilização de recursos áudio visuais, como a exposição de documentários, filmes e vídeos que abordem ou tragam alguma reflexão sobre questões ambientais. No entanto, a exposição desses materiais não elimina a necessidade de um debate prévio e depois de sua exposição.

Um caminho possível para tratar de educação ambiental é através da execução de projetos, entre os quais pode-se citar aqueles voltados para o cultivo de hortas nas escolas ou até mesmo em áreas verdes disponíveis cedidas por outros órgãos, empresas ou áreas públicas. Com isso, uma possibilidade é aliar alguns temas relacionados à educação ambiental com o projeto de construção de hortas, como alimentação saudável, uso de agrotóxicos, alimentos orgânicos, agricultura familiar, agricultura globalizada, uso da água, entre outros aspectos. 
Outras possibilidades factíveis e que dependem também do apoio do corpo diretivo e demais professores, são detalhes mínimos, que as vezes passam despercebidos e são essenciais, e que tornarão a escola um ambiente pensado através de alguns conceitos da educação ambiental, como na introdução de lixeiras diferenciadas/separadas, plantio e cultivo de árvores com o objetivo de deixar a escola mais verde e agradável sob o ponto de vista da arborização.

A escola também pode introduzir em seu Projeto Político Pedagógico, gincanas e atividades relacionadas ao recolhimento de materiais recicláveis, com foco, por exemplo, em áreas e pontos sensíveis à poluição e que podem evitar problemáticas ambientais e urbanas maiores. Sendo assim, há possibilidade de trabalhar com as chamadas Jornadas de Meio Ambiente, com a construção e aplicação de diferentes projetos, oficinas, palestras, seminários e cursos atrelados à educação ambiental (ABRANTES; MIRANDA; VASCONCELLOS, 2014).

A educação ambiental e patrimonial pode ser trabalhada de variadas formas e além de atividades possíveis de serem realizadas internamente na escola, como elaboração de vídeos, estudos dirigidos, redações, também há a possibilidade de execução de atividades externas, como saídas de campo, visitação a museus e áreas de proteção permanente. Pode-se citar também, a possibilidade de construção de projetos e iniciativas de conservação e manejo de determinadas áreas verdes da escola ou de outro local previamente selecionado ou acordado com o responsável legal.

Tais possibilidades carregam consigo inúmeros desafios para execução, como a falta de recursos, carência de materiais didático-pedagógicos, a rotina escolar, além da falta de preparo dos professores para trabalhar com a temática (MENEGUZZO; MENEGUZZO, 2013). Apesar das dificuldades relacionadas às temáticas, é possível construir o trabalho a partir de possibilidades metodológicas que extrapolem o já tão atrasado modelo tradicional presente nas escolas. 


\section{CONCLUSÃo}

A Educação Ambiental e Patrimonial são importantes estratégias para dar evidência às questões ambientais e algumas práticas inadequadas de tratamento de bens patrimoniais, que aliado às categorias da Geografia e seu peso teórico metodológico, fornecerão relevantes possibilidades para a formação de um arcabouço que contemple, de igual, modo o diálogo interdisciplinar tão caro ao ensino de Geografia. De igual maneira, a Educação Ambiental, metodologias ativas e a patrimonialidade trazem consigo a riqueza de aproximação de áreas do conhecimento e componentes curriculares diversificados, que podem ser modulados e inseridos no decurso de desenvolvimento de novas práticas didático-pedagógicas envolvendo o patrimônio cultural e natural.

Faz-se mister pensarmos em estratégias e caminhos para o engendramento de uma nova forma de olhar nossas relações com o mundo em que vivemos, perpassando pela relação com o outro e com nossas próprias ações e reflexões. Neste sentido, a Educação Ambiental e Patrimonial emerge como uma fonte da qual pode-se extrair alternativas para se chegar a este fim, do novo olhar e ação para o meio, partindo desde noções basilares e elementares do lidar e compreender a importância dos recursos naturais e seu consumo, como também o fomento de um patamar mais elevado no que diz respeito à problemática ambiental e patrimonial, partindo do microescalar até o macroescalar.

A Geografia escolar, por ser uma disciplina que é preocupada com a realidade local onde vivem os estudantes, possui um grande potencial para a abordagem e atribuição ainda maior de relevância da educação ambiental e patrimonial nas escolas. No entanto, deve-se ressaltar o perigo de tratar a educação ambiental e patrimonial apenas pelo viés denunciativo, sendo necessária uma postura propositiva, dialógica e que prime pelo caráter informativo dos bens culturais e naturais que compõem nossa realidade ambiental e social, e a escola, o ensino e as estratégias didático-pedagógicas afirmativas e diversificadas possuem papel fundamental nesse processo.

É preciso, portanto, pensar e promover ações no sentido de desenvolver ações de ensino e aprendizagem, com foco na Educação Ambiental e Patrimonial, levan- 
do-se em consideração a importância dos bens culturais e ambientais, bem como a passagem dos conceitos, diretrizes, prerrogativas, debates e demais interlocuções destas duas frentes. A Educação Ambiental e Patrimonial, fazem parte de uma agenda internacional, com vistas de entrada na escala nacional e local, oferecendo, desta maneira, uma gama imensurável de vias de trabalho em suas diferentes possibilidades de trabalho.

\section{REFERÊNCIAS}

ABRANTES, V.A.M.S; MIRANDA, M.G; VASCONCELLOS, C.A.B. Educação ambiental na escola: do papel à realidade - do discurso ao comprometimento. Revista Brasileira de Educação Ambiental, São Paulo- SP, v.9, n², p.424-435, 2014)

AIRES, B.F.C; BASTOS, R. As práticas pedagógicas dos professores da educação básica de Palmas - TO. Revista Brasileira de Educação Ambiental, Rio Grande SP, vol.6, p.52-61, 2011.

CARVALHO, I. C. de M. Educação Ambiental: a formação do sujeito ecológico. São Paulo: Cortez, 2004.

CASTRO, C. A importância da educação patrimonial para o desenvolvimento do turismo cultural. Partes, São Paulo, vol.30, 2006.

CAVALCANTI, Lana de Sousa. Ensinar Geografia para a autonomia do pensamento: o desafio de superar dualismos pelo pensamento teórico crítico. In: Anais do IX Encontro Nacional da ANPEGE. Goiânia: Universidade Federal de Goiás. Goiânia, 2011.

HENRIQUES, R.; TRAJBER, R. ; MELLO, S. ; LIPAI, E. M. ; CHAMUSCA, A. . Educação Ambiental: aprendizes de sustentabilidade. Brasília: SECADIMEC, 2007.

HORTA, M. L. P.; GRUNBERG, E.; MONTEIRO, A. Q. Guia Básico de Educação Patrimonial. Brasília: Instituto do Patrimônio Histórico e Artístico Nacional / Museu Imperial, 1999.

Fundamentos da educação patrimonial. In: Revista Ciências \& Letras $-\mathrm{n}^{\circ}$ 27 - jan/jun. Porto Alegre: Faculdade Porto-Alegrense de Educação, Ciências e Letras, 2000 p. 13- 36. 
IPHAN. Educação Patrimonial: Histórico, conceitos e processos. Brasília, Instituto do Patrimônio Histórico e Artístico Nacional, 2014.

JOVINO, D.P; CERQUEIRA FILHO, H.S. Educação Patrimonial nos anos finais do Ensino Fundamental: uma análise das metodologias aplicadas em sala. RELACultRevista Latino-Americana de Estudos em Cultura e Sociedade, vol.04, ed. Especial, p.1-10, 2018.

. Quando a Geografia crítica pode ser um pastel de vento. Mercator, Fortaleza, v. 3, n. 6, 2004.

LEMOS, Carlos. O que é Patrimônio Histórico. São Paulo: Brasiliense, 1981.

LIBERALESSO, C.P. A Educação patrimonial e o ensino de Geografia: experiência nas escolas públicas da cidade de Santa Maria- RS. Dissertação de Mestrado em Geografia, Universidade Federal de Santa Maria, Santa Maria- RS, 2013.

LOUREIRO, C. F. B. Premissas teóricas para uma Educação Ambiental transformadora. Ambiente \& Educação (FURG), Rio Grande, v. 8, p. 37-54, 2003.

LUCKESI, C. C. Filosofia da Educação. São Paulo: Cortez, 1994.

MENEGUZZO, S.I; MENEGUZZO, P.M. Educação Ambiental: possibilidades e desafios no processo de ensino e aprendizagem da Geografia escolar. Revista Brasileira de Educação Ambiental, Rio Grande- SP, v.8, n.2, P.10-19, 2013.

MEYER, M. A. A. Educação ambiental: uma proposta pedagógica. In: Em aberto, Brasília, v. 10, n. 49, p. 40-45, jan./mar. 1991.

MOREIRA, R. A Geografia e a Educação Ambiental: o modo de ver e pensar a relação ambiental na Geografia. Espaço em Revista, vol.11, n¹, p.-11-19, 2011.

MOURA, P.E.F; MEIRELES, A.J.A; TEIXEIRA, N.F.F. Ensino de Geografia e educação ambiental: práticas pedagógicas integradas. Geosaberes, Fortaleza, v.6, n.11, p.47-59, 2015.

SILVA, Eunice Isaias da. Charge, cartum e quadrinhos: linguagem alternativa no ensino de geografia. In: Revista Solta a Voz. Vol. 18, nº 1. p. 41-49. 2007.

SURMACZ, E.C.S.; LEME, R.C.B. O professor é, a priori, responsável pela motiva- 
ção do aluno em sala de aula. Revista de Ensino de Geografia, Uberlândia, v.6, n.11, p.37-64, 2015.

UNESCO. Patrimônio mundial no Brasil. Disponível em: https://pt.unesco.org/fieldoffice/brasilia/expertise/world-heritage-brazil. Acesso em 20 de abr. de 2017.

VIÉGAS, A. Educação ambiental e complexidade: uma análise a partir do contexto escolar. Tese de Doutorado Em Educação. Rio de Janeiro: UFRJ, 2010.

VLACH, V. Ensino de Geografia no início do século XXI: Desafios e perspectivas. Mérida (México): Anais do Encuentro de Geógrafos de América Latina, 2003. 


\section{A EXTENSÃO COMO METODOLOGIA}

\section{ATIVA DLALÓGICA NO ENSINO \\ DE GEOGRAFLA EM \\ CENTROS SOCIOEDUCATIVOS}

DIMITRI SILVA SOBRAL

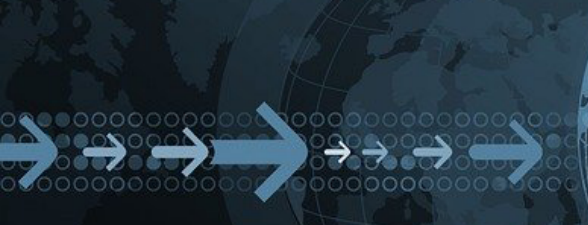
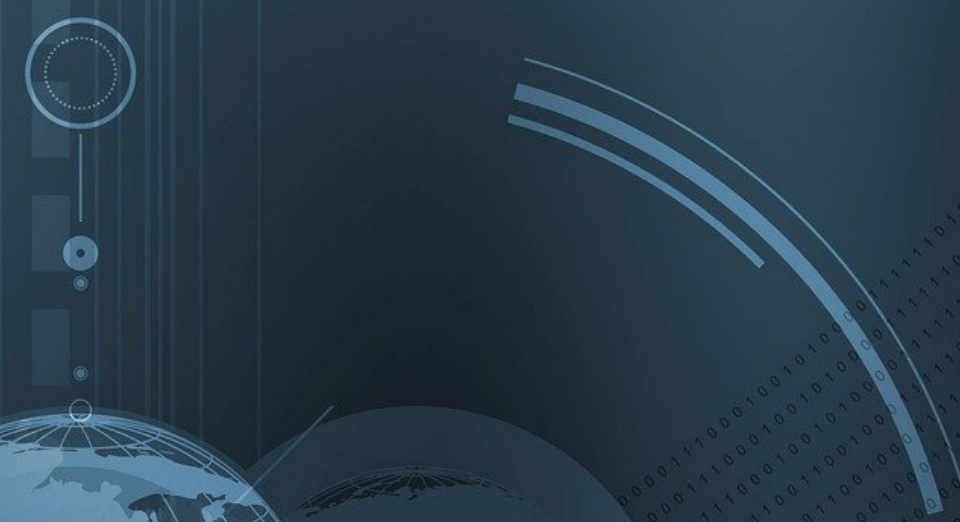


\section{INTRODUÇÃO}

O presente trabalho buscará trazer subsídios à discussão sobre as limitações e particularidades do processo de ensino-aprendizagem em colégios sediados em centros socioeducativos, os locais de ressocialização de crianças e adolescentes em conflito com a lei, um eufemismo para prisão infantil. Nesse sentido, com o auxílio das noções sobre as metodologias ativas de aprendizagem, pretende-se analisar sua aplicação em um estudo de caso e seus possíveis benefícios aos agentes centrais envolvidos nesta sala de aula peculiar.

O estudo de caso escolhido é localizado na cidade do Rio de Janeiro, o DEGASE (Departamento Geral de Ações Sócio Educativas) do bairro do Galeão, na llha do Governador, onde funciona o Colégio Estadual Padre Carlos Leôncio da Silva, cujo público de alunos é formado totalmente por crianças e adolescentes que estejam sob a tutela do Estado em regime prisional.

A justificativa para o recorte selecionado para o estudo de caso é a participação do autor do presente trabalho em projeto de extensão universitária pelo Programa de Pós-graduação em Geografia da Universidade Federal do Rio de Janeiro em parceria com a instituição C.E. Padre Carlos Leôncio da Silva. Nesta extensão, professores e estudantes de graduação e pós-graduação do departamento de geografia da UFRJ visitam, periodicamente, as salas de aula da instituição parceira e lecionam, em conjunto com docentes locais, oficinas didáticas que permitam e estimulem a participação dos estudantes de maneira ativa, tendo como base conceitual norteadora o construtivismo vigotskiano. Nesse sentido, propõe-se que as salas de aulas tradicionais (e neste caso, ainda mais autoritárias) percam seus lugares para ambientes onde a colaboração, a autonomia e o espírito crítico do alunado sejam as novas "regras" nesse ousado processo de ensino-aprendizagem em que o papel da instituição é revisado na prática.

No que tange a sua estrutura administrativa, a instituição está sob gerência da Secretaria de Estado e Educação, especificamente à Diretoria Prisional e Socioeducativa (Diesp), responsável pelas escolas localizadas em unidades da Secretaria de Administração Penitenciária (Seap), cujo público é maior de dezoito anos, e em 
unidades do Degase (Departamento Geral de Ações Socioeducativas) cuja tutela são jovens apreendidos pela Polícia Militar do Estado do Rio de Janeiro com idades entre doze e dezessete anos, caso do C. E. Padre Carlos Leôncio da Silva.

Figura 1 - Estrutura administrativa do colégio estudado

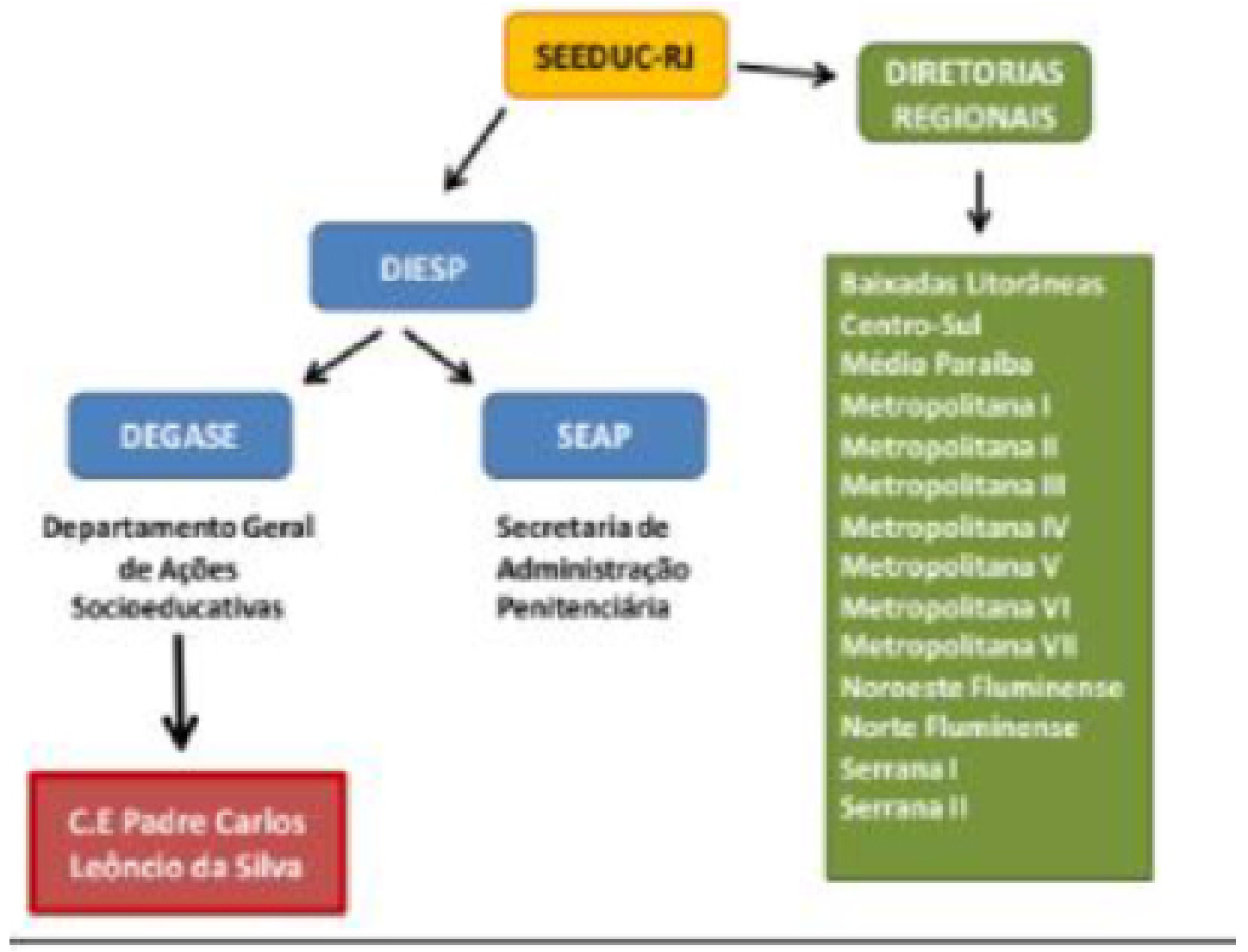

Fonte: Silva e Nascimento (2020, p.7).

A motivação para o objeto da pesquisa se deve à particularidade dos alunos dos Centros Socioeducativos que comumente se apresentam de difícil acesso ao meio acadêmico. No entanto, a instituição a ser analisada, além de se apresentar um caso relevante pela quantidade de aproximadamente 5 mil novos jovens apreendidos por ano, oriundos de diferentes áreas do Estado do Rio de Janeiro (SILVA e NASCIMENTO, 2020), possui parceria com o projeto de extensão citado anteriormente, sob a modalidade de oficinas de geografia urbana, facilitando os contatos com a instituição que permitam a aproximação junto aos jovens e aos colaboradores do centro, o que permitirá futuros aprofundamentos nas questões relativas aos padrões de moradia, nível de renda e escolaridade familiar, bem como acesso ao saneamento básico. Para este ensaio, no entanto, a discussão irá se limitar ao estudo de caso como um 
elemento prático desafiador para educandos e educadores.

A proposta do artigo é apresentar as características gerais dos estudantes do C.E. Padre Carlos Leôncio e a necessidade da aplicação de novas metodologias em sala de aula, bem como discutir os seus benefícios para o público atendido e para os professores e estudantes de licenciatura como um estímulo à urgência de renovação e readaptação de nossos métodos didáticos. A metodologia consiste na pesquisa em acervos bibliográficos a respeito da socioeducação, de autonomia enquanto prática ética e libertadora da pedagogia (FREIRE, 1967) e, não obstante, das ações de extensão como metodologia ativa da aprendizagem. Nesse sentido, este ensaio tem como objetivo geral trazer subsídios a respeito de metodologias ativas para a aprendizagem e suas possibilidades para o sistema socioeducativo, utilizando como estudo de caso as oficinas de geografia urbana praticadas no C.E. Padre Carlos Leôncio da Silva, unidade escolar para jovens e crianças encarceradas no Degase Dom Bosco, Ilha do Governador, Rio de Janeiro.

Complementarmente, este ensaio também visa discutir as limitações determinantes para os modelos mais adequados à particularidade do público de alunos, bem como analisar a importância da educação e, por conseguinte, da assimilação para os alunos vinculados ao sistema prisional infantil e, finalmente, debater a importância dos projetos de extensão como uma metodologia ativa da aprendizagem retroalimentadora para as esferas educacionais envolvidas.

\section{A SOCIOEduCAÇÃO: LIMITAÇõES, PROBlemAS E POSSIBILIDADES}

A socioeducação é, segundo o Estatuto da Criança e do Adolescente, uma maneira de garantir o direito à escolarização a jovens e crianças que estejam sob a tutela do Estado em regime prisional, formalmente chamado de internação definitiva. Apesar do nome, esse regime promove o encarceramento pelo período de seis meses até três anos, e é a medida punitiva para os casos de delitos mais significativos, como grave ameaça ou violência à vítima, reincidência de delito cometido ou descumprimento de alguma medida imposta como punição, conforme é possível ver a apresentação feita por Silva e Nascimento (2020). 
Nesse sentido, os centros socioeducativos surgem para, em tese, estimular a ressocialização de crianças e adolescentes em regimes de internação definitiva, durante o período em que estão nas unidades, cumprindo seus julgamentos ou ainda aguardando os mesmos. A constante incerteza e a volatilidade da permanência dos alunos apreendidos resultam na elaboração de modelos de ensino ainda mais alternativos do que aquele conhecido no sistema convencional e seriado, sendo necessária, portanto, a criação do sistema multisseriado, que permite a abertura de turmas para educandos de diferentes idades e, principalmente, diferentes estágios dos ensinos fundamental e médio. O modelo multisseriado é o mais comum nos centros socioeducativos e se deve ao fato de muitos desses jovens não terem frequentado a escola regularmente antes de serem apreendidos, ou mesmo nunca nem sequer iniciaram os estudos.

Matos (2006), citado por Freitas e Ramires (2010, p. 5), afirma que:

"[...] as crianças e adolescentes em conflito com a lei são amparados pela legislação brasileira por meio das políticas socioeducativas, que se objetivam a reintegrá-los à sociedade. Em contrapartida, as ações jurídicas e institucionais demonstram uma prática por vezes arbitrária e desumana nas instituições que ainda conseguem manter certa ordem de convívio pacífico. A tensão é alimentada pelos ânimos dos próprios adolescentes, dos quais boa parte já se encontra formada por altos padrões de violência".

Não obstante, segundo Freitas e Ramires (2010), as unidades de internação enfrentam as responsabilidades de um sistema falido e mal gerido desde o momento da detecção do delito, sua catalogação, passando pelas providências jurídicas e penais, culminando, finalmente, na punição em forma de medida socioeducativa. Ainda segundo os autores, esse é um dos principais fatores pelos quais os centros socioeducativos acumulam os maiores problemas do sistema penal infanto juvenil.

Diante desse breve cenário, é possível notar de imediato que o ambiente é hostil para o alunado, para equipe pedagógica que muitas vezes é pouco respaldada, para equipe de agentes penitenciários e também para a equipe docente, especialmente tendo em vista as particularidades da estrutura e do modelo multisseriado nessas instituições, além, é claro, da violência nem sempre subjetiva entre os próprios jovens, oriundos de diferentes facções atuantes no tráfico de drogas no estado do Rio de Janeiro. É nesse sentido que as metodologias ativas, especialmente aquelas mais lúdicas e integradoras, fazem sentido em um centro socioeducativo. Aqui, mais do 
que em qualquer outra instituição no campo da educação, o construtivismo deve ser uma corrente pedagógica presente com frequência, pois é nessa premissa dialógica em que o estudante é protagonista e deve ser um agente frequentemente engajado na sua construção de conhecimento orientada.

\section{A EDUCAÇÃO COMO PRÁTICA DA LIBERDADE}

A presente seção deste breve ensaio faz referência a obra de Freire (1967), onde, entre outras diversas importantes e fundamentais reflexões no campo da educação, a liberdade é entendida como a necessidade humana para a autorreflexão. Os questionamentos mediados pelo $e u$, mas instigados pela educação permitem ao educando a sua incessante busca pela liberdade. No caso de estudantes aprisionados em celas eufemisticamente chamadas de alojamentos, a sala de aula parece ser um dos poucos e mais valiosos lugares para o incentivo à liberdade, ou seja, o estímulo a ser dado pelos educadores aos educandos que, mesmo apreendidos, possam não temer a liberdade, e sim lutar por ela, compreendendo e refletindo sobre os processos presentes em nossa sociedade.

A contradição entre seres humanos apreendidos, mas também estudantes em busca de sua liberdade em uma sala de aula gradeada não deve ser fator limitante para que professores e equipe pedagógica estimulem a busca pela autonomia. $\mathrm{O}$ construtivismo, acompanhado de metodologias práticas em sala de aula pode ser o grande espelho necessário para que a tão desejada mudança aconteça. Segundo Freire (1968), o indivíduo oprimido é, por vezes, também opressor, justamente porque é na opressão e na violência onde ele tem o testemunho de humanidade, ou seja, é na violência e no conflito em que diversos dos jovens internos tiveram seus exemplos e suas sombras por boa parte da vida. Portanto, o caminho da delegação de autonomia construtivista, aliado à aulas lúdicas e ativas, têm indicado, nesse sentido, que são conceitos que devem estar presentes no planejamento pedagógico para a sala de aula. O docente não deve ser mais um exemplo hostil para aquilo que os educandos entendem como humanidade.

Com o auxílio de Freire (1996), é possível dizer que, especialmente em casos como os dos centros socioeducativos, o professor deve ser aquele que confere ao aluno a autonomia, se diferenciando de outros agentes opressores do Estado: 
"[...]O respeito à autonomia e à dignidade de cada um é um imperativo ético e não um favor que podemos ou não conceder uns aos outros. [...] O professor que desrespeita a curiosidade do educando, o seu gosto estético, a sua inquietude, a sua linguagem, mais precisamente, a sua sintaxe e sua prosódia; o professor que ironiza o aluno, que o minimiza, que manda que ele se ponha em seu lugar ao mais tênue sinal de sua rebeldia legítima, tanto quanto o professor que se exime do cumprimento de seu dever de propor limites à liberdade do aluno, que se furta ao dever de ensinar, de estar respeitosamente presente à experiência formadora do educando, transgride os princípios fundamentalmente éticos de nossa existência". (FREIRE, 1996 p. 24)

Krauskopf (2003) elenca quatro enfoques sobre as concepções de juventude presentes na literatura, sendo a primeira como a etapa de preparação, a que transita entre a infância e a fase adulta. As outras seriam a juventude como etapa problemática, juventude como ator estratégico para o desenvolvimento e, por fim, como cidadã, ou seja um sujeito detentor e conhecedor de seus direitos. Lauerman (2018), a partir dessas quatro noções sobre a juventude, aponta que aquela encarcerada é aquela que vive a fase da vida como etapa problemática, especialmente pela convivência posterior com problemas como violência familiar e policial, gravidez não planejada e, frequentemente, com o tráfico de drogas.

É exatamente por razões como as apontadas pelos autores supracitados que, apesar dos desafios e das inúmeras barreiras, a sala de aula de um centro socioeducativo também deve ser o espaço de conflito, mas apenas o conflito de ideias e de autorreflexão, conforme aponta Freire (1967). Especialmente visando o público do C. E. Padre Carlos Leôncio da Silva, o conceito e a discussão sobre o direito à cidade se mostram pertinentes. Trata-se de um grupo oriundo de uma provável segregação e precarização em suas vidas, antes mesmo da apreensão pelo Estado. Segundo Carlos (2005), a cidade é resultado de histórias particulares que se realizam em história coletiva. Não obstante, nessa perspectiva, só existe cidade em função dos percursos e trajetórias que ela torna possível. Nesse sentido, a apreensão dos jovens e crianças é a materialização do direito marginalizado à cidade, resultando em direito negado, o que intensifica a discussão sobre a concreta ressocialização desses indivíduos.

Com base na contradição do poder público, ora agente facilitador da segregação, ora responsável direto e emergente para tomar medidas que solucionem a insegurança pública, é pertinente a associação entre os conceitos de Espaços de esperança (HARVEY, 2004) e Direito à Cidade (LEFEBVRE, 2001). O primeiro, por- 
que estimula às mudanças, à utopia, ao progresso e à tentativa de equanimidade, apesar das desigualdades presentes no espaço urbano. O segundo, porque admite, especialmente com a contribuição de Carlos (2005), a realidade em que a cidade é o lugar dos conflitos que surgem como reivindicação, como luta da sociedade contra aquilo que segrega, afasta e impede a realização da vida na cidade, clamando pela construção de um projeto futuro.

É na cidade, no espaço urbano, na metrópole do Rio de Janeiro que muitos desses delitos são cometidos. É também na delimitação desse espaço onde a violência se faz presente em diversas famílias, também é nele onde os processos de segregação residencial não intencional (Villaça, 1998) ocorrem de maneira agressiva, intensificando a exclusão social, negando ou negligenciando recursos como a moradia, o saneamento e, não obstante a educação. Porém, tem de ser também o espaço da utopia, do movimento, da autonomia e da liberdade. Que seja em uma fração pequena desse todo urbano, como é uma sala de aula socioeducativa, mas que ela seja um espaço de reconstrução e de esperança.

\section{A EXTENSÃo COMO METOdOLOGIA ATIVA}

O presente estudo de caso, como dito nas seções anteriores, é alvo de um projeto de extensão entre a Universidade Federal do Rio de Janeiro e o C.E. Padre Carlos Leôncio da Silva. A iniciativa deu seus primeiros passos em 2017, por intermédio dos grupos PET Geografia (Programa de Educação Tutorial) e Gruce (Grupo de Pesquisas sobre Centralidade e Reestruturação Urbana), com o intuito de proporcionar atividades práticas de iniciação à docência para estudantes dos cursos de graduação e pós-graduação do departamento de geografia da UFRJ. As atividades consistem em oficinas didáticas baseadas em temas de pesquisas dos universitários a níveis de iniciação científica, mestrado, doutorado e pós-doutorado, mas apresentadas de formas lúdicas e ativas, visando a participação constante dos estudantes internos do centro socioeducativo para, acima de tudo, colaborarem com suas visões de mundo a respeito de determinados conteúdos geográficos presentes no espaço urbano contemporâneo.

Visando a articulação no tripé Ensino-Pesquisa-Extensão, o projeto se pauta na criação de um ambiente material e intelectual que aproxime a produção científica 
e acadêmica dos estudantes de licenciatura em geografia à peculiaridade do ensino em centros socioeducativos. Como principais objetivos, a iniciativa se propõe a despertar nos estudantes de graduação e pós-graduação o interesse pelas atividades de extensão, desenvolver habilidades de ensino, pesquisa e extensão em conjunto com os membros da escola e, principalmente, permitir aos alunos apreendidos o contato com a universidade através de oficinas didáticas (Disponível em: extensao.ufrj.br)

Segundo Freire (1983), historicamente há uma grande confusão no que diz respeito ao significado da prática extensionista, sendo frequentemente associada a intervenções pouco horizontais de um grupo a outro, como tentativas heterônomas de quem transporta o conhecimento para aqueles que não o têm, como um fardo a ser carregado para salvar a quem não detém os saberes. Não obstante, o autor ainda afirma:

"[...] educar e educar-se, na prática da liberdade, é tarefa daqueles que sabem que pouco sabem - por isto sabem que sabem algo e podem assim chegar a saber mais - em diálogo com aqueles que, quase sempre, pensam que nada sabem, para que estes, transformando seu pensar que nada sabem em saber que pouco sabem, possam igualmente saber mais". (FREIRE, 1983, p. 15)

Nesse sentido, o projeto de extensão deste estudo de caso não se propõe a reproduzir sistemas hierárquicos e nem mesmo a invadir o espaço desse público de alunos a fim de lecionar aulas de modo tradicional, com pouca ou nenhuma participação da turma. Na realidade, é possível dizer que o objetivo dessa extensão é a colaboração mútua entre pesquisadores e estudantes internos do centro socioeducativo. De um lado, a universidade ganha a possibilidade de divulgar pesquisas de seus estudantes que, por sua vez, adquirem ricas experiências no que diz respeito à iniciação docente, pois passam a ter contato com um alunado peculiar no que diz respeito às suas origens socioespaciais, aos seus históricos familiares e a sua fragmentação escolar - tendo em vista que o Degase Dom Bosco recebe jovens de todo o estado do Rio de Janeiro, do sexo masculino, separados por cela e turma de acordo com a facção criminosa com a qual dizem pertencer. Além disso, a maioria dessas classes no C.E. Carlos Leôncio é na modalidade multisseriada, ou seja, formada por crianças e adolescentes com seus estudos regulares, interrompidos ou não, entre todas as séries do ensino fundamental e as do ensino médio, conforme apontam Silva e Nascimento (2020). Ainda segundo os autores, não é incomum o aparecimento de 
jovens que nunca tenham frequentado a escola com regularidade.

Do outro lado, não por causas, mas por motivações diferentes, o centro socioeducativo, em especial os seus alunos, passam a ter seus primeiros contatos com uma universidade e com a possibilidade de estarem nela em algum dia. Não obstante, por estarem participando de oficinas didáticas que variam entre seminários, debates informais, dinâmicas em grupo e apresentações teatrais, os estudantes internos adquirem a possibilidade de enxergarem traços da realidade que vivem na metrópole do Rio de Janeiro, mas pela ótica de aulas não tradicionais que se pretendem, para além de lúdicas, divulgarem pesquisas no campo da geografia e, principalmente, oferecerem sentido real ao estudante que, somando ao seu próprio conhecimento empírico de mundo, possa encontrar aquilo que o liberte, apesar da prisão.

"[...] Por isto mesmo é que, no processo de aprendizagem, só aprende verdadeiramente aquele que se apropria do aprendido, transformando-o em apreendido, com o que pode, por isto mesmo, reinventá-lo; aquele que é capaz de aplicar o aprendido-apreendido a situações existenciais concretas. Pelo contrário, aquele que é 'enchido' por outro de conteúdos cuja inteligência não percebe; de conteúdos que contradizem a forma própria de estar em seu mundo, sem que seja desafiado, não aprende. Para isto, é necessário que, na situação educativa, educador e educando assumam o papel de sujeitos cognoscentes, mediatizados pelo objeto cognoscível que buscam conhecer. A nada disto nos leva a pensar o conceito de extensão". (FREIRE, 1983, p.16)

A exaustivamente comentada colaboração mútua entre esferas federal, representada pelos pesquisadores universitários da UFRJ, e estadual, representada pela equipe pedagógica e, principalmente, pelos internos do centro socioeducativo, é, do ponto de vista didático, uma metodologia ativa para a aprendizagem ambígua e, por isso mesmo, importante e promissora para ambos envolvidos. Não se trata, portanto, de uma prática de ensimesmamento, pois se propõe à desafiadora e complexa missão de conferir liberdade para participações em diferentes tipos de atividades pedagógicas e, não obstante, conferir liberdade intelectual, promovendo o fortalecimento de um ensino crítico. No mesmo sentido, a extensão também confere oportunidades singulares no que diz respeito à iniciação à docência, pois permite ao estudante universitário, especialmente aquele que se postula à carreira no magistério, um contato com uma fração do ensino básico e público pouco mencionada ao longo dos estudos no curso de licenciatura, mas que representa uma significativa parcela da população 
brasileira que está à margem do ensino regular, do meio acadêmico e, principalmente, da cidade.

\section{CONSIDERAÇÕES FINAIS}

O presente ensaio a respeito da necessidade e importância das metodologias ativas para aprendizagem, ou seja, do ensino estimulando o pensamento crítico e autônomo do aluno é uma ramificação de um projeto de mestrado em curso no Programa de Pós-graduação em geografia, da UFRJ, intitulado "O direito à cidade em uma cidade gerida pelo medo: uma cartografia dos jovens em conflito com a lei no estado do Rio de Janeiro". O autor desse texto, durante dois anos de sua graduação, foi estudante extensionista do projeto Oficinas de Geografia Urbana, realizado junto ao C.E. Padre Carlos Leôncio da Silva, localizado nas dependências do Degase Dom Bosco. Nesse sentido, o autor é um dos casos em que a retroalimentação pesquisa-extensão surtiu efeitos continuativos. No entanto, com o intuito de aprofundar os estudos sobre os efeitos da extensão sobre os educandos internos, tão logo seja possível e seguro, com as devidas autorizações e protocolos de prevenção contra os efeitos da pandemia de covid-19, trabalhos de campo serão formalmente realizados na unidade, dialogando com coordenadores, professores e principalmente com os alunos em futuras entrevistas semi-estruturadas. Outras questões como a origem socioespacial, históricos de vida familiar e distribuição dos jovens entre as facções criminosas do Rio de Janeiro também fazem parte dessa pesquisa e serão alvos de aprofundamento em ensaios posteriores.

No que diz respeito à importância da educação para essa parcela da população brasileira, bem como qual é o modelo didático mais adequado à particularidade do público, é pertinente recorrer aos debates sobre currículo, sobretudo entre Young (2014) e Miller (2014). A partir dessas óticas divergentes, é possível analisar o estudo de caso deste trabalho como uma situação em que a sociologia da educação deve orientar o trabalho do professor, ou seja, um currículo formal pode auxiliar o trabalho docente para lecionar suas aulas e seus conteúdos especializados, mas é papel do profissional utilizar a didática adequada para o seu alunado, conforme os estudos do primeiro autor. 
Ao contrário, Miller (2014), parte de uma visão que enaltece em menor proporção a objetividade do trabalho do educador, aderindo a uma versão subjetiva de currículo, ou seja, priorizando as relações e identidades individuais entre professor e aluno, pois, segundo a autora, isso evitaria normatizações pedagógicas que empoderem aqueles que mais possuem poder e excluem aqueles que menos têm. Não é, portanto, incorreto e tampouco incoerente, aproveitar ambas as teses, embora sejam quase antagônicas entre si. Por um lado, apesar das turmas multisseriadas, as disciplinas são ministradas individualmente pelo docente de cada disciplina. Desta normatização não há como escapar, cabendo, sim, ao professor, a missão de viabilizar o diálogo inteligível para as especificidades das turmas. Por outro lado, exatamente por essas razões, há, de fato, a necessidade do educador, inclusive do extensionista, buscar uma adaptação que dê conta da rica pluralidade de histórias de vida dos indivíduos da turma. É nesse sentido, portanto, que independentemente do método utilizado, o objetivo deve ser transformar a sala de aula gradeada em um espaço de esperança, exercendo a educação como prática da liberdade.

De acordo com Magalhães e Hirata (2017), o fracasso do sistema prisional não é um acaso, mas sim um projeto. Para os autores, o Estado se interessa pelo fracasso da prisão, pois é assim que se produz e reforça um meio social delinquente, fazendo com que seja necessário o uso da força para recuperar a ordem. Não obstante, Foucault (2014), afirma que a prisão é uma forma de tortura e a busca pela necessidade da implementação da ordem, ou seja, das apreensões e tratamentos violentos, são características de dimensões supliciantes que visam a expressão do poder. O aprisionamento é, nesse sentido, produção e reprodução das desigualdades entre aqueles que têm e os que não têm o poder. É na cidade onde esses processos ideologicamente sutis, mas fisicamente violentos ocorrem, é na cidade onde, segundo Villaça (1998), há espaços para aqueles que escolhem onde viver, estudar, comprar e circular, e espaços restantes para aqueles que sobram.

Portanto, é possível e necessário afirmar que o projeto do fracasso não pode ser alimentado e reproduzido pelos docentes, especialmente pelos que trabalham em centros socioeducativos. É urgente que as humanidades espelhadas pelos estudantes sejam diferentes daquelas encontradas anteriormente à apreensão, bem como 
diferentes daquelas exclusivamente punitivas e opressoras do sistema penitenciário. O educando, sobretudo nesses casos, deve ser o centro do processo de ensino-aprendizagem e, não obstante, aquele a quem se deve estimular a liberdade a um nível em que se desprenda das algemas literais e metafóricas de nossa sociedade.

\section{REFERÊNCIAS}

CARLOS, Ana Fani Alessandri. $O$ direito à cidade e a construção da metageografia. Revista Cidades, v. 2, n. 4, 2005.

FOUCAULT, Michel. Vigiar e Punir. Petrópolis: Vozes, 2014.

FREIRE, Paulo (1967). Educação como prática da liberdade. Editora Paz e Terra, 2014.

(1968). Pedagogia do oprimido. rev. e atual. Rio de Janeiro: Paz e Terra, 2011.

(1983). Extensão ou comunicação?. Editora Paz e Terra, 2014.

(1996) Pedagogia da autonomia. Saperi necessari per la, 2018.

FREITAS, O. A.; RAMIRES, J. C. L. Jovens infratores e políticas públicas: reflexões acerca do centro socioeducativo de Uberlândia. Observatorium - Revista eletrônica de Geografia. Ano II, N. V. nov. 2010.

HARVEY, David. Espaços de Esperança. Spaces of Hope. Tradução de Adail Ubirajara Sobral e Maria Stela Gonçalves. São Paulo: Edições Loyola, 2004.

KRAUSKOPF, Dina. La construcción de políticas de juventud en Centroamérica. Políticas públicas de juventud en América Latina: políticas nacionales, 2003.

LAUERMANN, A. A violência da cidade sob o olhar da juventude. In: Claudia Lucia Silva Mendes; Elionaldo Fernandes Julião; Janaina de Fátima Silva Abdalla. Soraya Sampaio Vergílio; (Orgs.). Restrição e privação de liberdade: Questões, desafios e perspectivas. Rio de Janeiro, DEGASE, 2018.

LEFEBVRE, Henri. tradução Rubens Eduardo Frias. $\mathbf{O}$ direito à cidade. São Paulo: Centauro, 2001.

MATOS, R. N. Crime e castigo: reflexões sensíveis sobre adolescentes privados de liberdade em Uberlândia. 2006. 128 f. Dissertação (Mestrado em História) - Instituto de História, Universidade Federal de Uberlândia, Uberlândia, 2006. 
MAGALHÃES JR., J. C.; HIRATA, D. Governar pela crítica: o reformismo carcerário em Vigiar e Punir. Dilemas, Edição Especial n. 2, 2017.

MILLER, Janet. Teorização do currículo como antídoto contra/na cultura da testagem. Revista e-Curriculum, São Paulo, v. 12, n. 03 p. 2043 - 2063 out./dez. 2014.

SILVA, William Ribeiro; NASCIMENTO, Bruno Pereira do. Ensino de Geografia e exclusão social: buscando aproximação entre ensino, pesquisa e extensão em uma escola socioeducativa. Revista Ensino de Geografia (Recife). V. 3, n 2, 2020.

VILLAÇA, Flávio. Espaço intra-urbano no Brasil. Studio nobel, 1998.

YOUNG, Michel. Teoria de currículo: o que é e por que é importante? Cadernos de Pesquisa, v.44 n.151, 2014. 


\section{PROPOSTA DE SEQUEANCIA DIDÁTICA PARA O ENSINO DE GEOGRAFIA: ATMOSFERA TERRESTRE}

\section{FERNANDO GAMILLO SANTOS GANO}

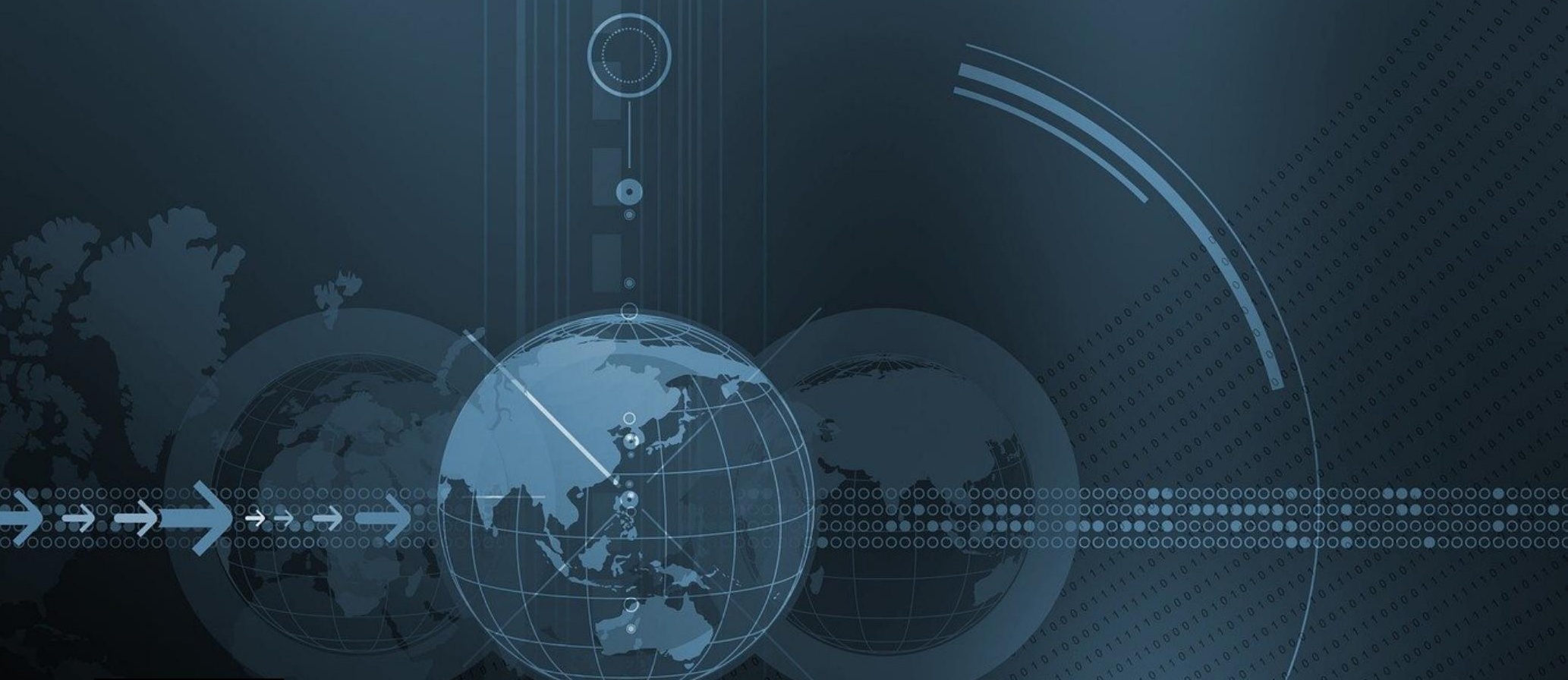

1 Doutorando do Programa de Pós-Graduação em Geografia IGCE-UNESP-Rio Claro. Graduado e Licenciado em Geografia IGCE-UNESP-Rio Claro. Atualmente é professor adjunto de Geografia do município de Elias Fausto-SP e realiza pesquisas na área industrial e em metodologias de ensino em Geografia. E-mail: fernandocamillo007@hotmail.com 


\section{INTRODUÇÃo}

As modificações que têm ocorrido no mundo, após a consolidação do meio técnico-científico-informacional (SANTOS, 1997) estabelece o progresso da divisão do trabalho com significativas transformações nos sistemas produtivos e na reprodução do cotidiano das sociedades. Dessa forma, a Geografia torna-se uma ferramenta essencial para compreender as mudanças cotidianas e formar cidadãos críticos a cerca das imposições do mundo contemporâneo.

A construção de cidadãos críticos perpassa condições concretas de ensino e de aprendizagem no que tange o desenvolvimento das funções psíquicas superiores. Segundo Martins (2013) as funções psíquicas superiores são identificadas na atenção voluntária, memória lógica, percepção e o raciocínio, envolvendo processos de análise, síntese, comparação, generalização e abstração, pela psicologia histórico-cultural.

Na perspectiva da psicologia histórico-cultural, o conhecimento emerge da atividade humana, que é social, mediada por processos históricos vivenciados empiricamente. Segundo Cavalcanti (2005, p.189) “a atividade humana é produtora, por meio dela o homem transforma a natureza e a constitui em objeto de conhecimento (produção cultural) e, ao mesmo tempo, transforma a si mesmo em sujeito de conhecimento".

No presente artigo será apresentada a importância de uma aprendizagem significativa nas aulas de Geografia por meio de uma sequência didática. Assim sendo, a utilização de sequências didáticas denotam ações que tornam reais a aprendizagem dos alunos, sendo elas construídas pelo arcabouço teórico do professor e sua tomada de decisão em relação às metodologias de ensino e os pressupostos didáticos.

As metodologias de ensino propõem um conjunto de ações organizadas por tarefas e exercícios para uma atividade de aprendizagem. Dessa forma, a atividade é proposta pelo professor na escolha de seus conteúdos que serão assimilados pela mediação. Segundo Gonçalves (2018, p. 218) “a mediação é constituída da seleção pelo professor de instrumentos e signos que são organizados em ações e, dentro delas, tarefas e exercícios, orientados por objetivos e motivos". 
Segundo Martins (2013, p. 133) "os signos se apresentam, como conteúdos da educação e ela como traço ineliminável da humanização". Os conteúdos conceituais e científicos devem ser desenvolvidos por meio de atividades problematizadoras, que exaltem as transformações hodiernas que perpassam a vida dos alunos. Dessa forma, a abrangência de conteúdos atitudinais e procedimentais, ampliará a análise da realidade, transformando os alunos em sujeitos críticos. Portanto, é por meio dos conteúdos procedimentais, que os conteúdos conceituais são desenvolvidos com o objetivo maior: a aprendizagem e o desenvolvimento.

A aprendizagem significativa na Geografia pode traduzir para ótica do professor a prática libertária. $O$ desejo de um ensino significativo para além de conceitos e definições, no qual se promova associações entre os conteúdos da disciplina, as evidências empíricas presentes no experenciar cotidiano e o conhecimento prévio dos estudantes. Desse modo, faz-se necessário compreender professores reflexivos como agentes facilitadores de práticas significativas, contribuindo para o avanço das discussões e debates.

Martins (2015) afirma que a reflexão apresenta-se como o mais importante objetivo para a formação de professores, onde o objeto dessa reflexão é a própria prática representada na realização efetiva das estratégias e dos procedimentos formativos. Sendo assim, destacada por Zeichner e Liston (1987) uma distinção entre três níveis de reflexão, quais sejam: técnica, prática e crítica.

O primeiro nível da reflexão, denominada técnica, analisa as ações explicitas dos procedimentos adotados por um professor. O segundo nível incorpora o conhecimento prático no que tange as experiências já adquiridas e, que precisarão ser adquiridas para resolver novas problematizações. O terceiro nível implica na análise do processo construído, de maneira crítica, destacando a consciência do papel do professor, sua prática humanizadora e o cenário político-ideológico pelo qual se encontra inserido.

Urge caracterizar a seguir, uma sequência didática evidenciando a importância de seu conteúdo para prática pedagógica, para a vida dos alunos e para a literatura de Geografia. Todavia, o tema pesquisado foi descrito a partir de seus pressupostos científicos, metodológicos e na utilização de instrumentos didáticos para a prática em sala de aula. 


\section{DESENVOLVIMENTO}

O conteúdo abordado refere-se à aprendizagem do Sistema Atmosférico e suas especificidades, compreendendo também, a relação que o homem estabelece com a natureza e seu cotidiano. O conteúdo é caracterizado de forma que o aluno busque fenômenos atmosféricos que altere sua rotina habitual, bem como, suscitar suas experiências sob a ótica singular para a totalidade desses fenômenos na Terra.

Nesta perspectiva, o saber humano e as suas experiências vividas são valorizadas. Desse modo, podem-se compreender hábitos, modos de sobrevivência e práticas de vida de indivíduos ou grupos sociais, que participam de forma significativa nas transformações do espaço geográfico e da configuração da paisagem. Assim sendo, os estudos deslocam-se da singularidade numa relação que parte do local para o global, valorizando também, as interpretações e o cotidiano das pessoas.

Segundo Corrêa (2000, p. 32) "a Geografia Humanista está assentada na intuição, nos sentimentos, na experiência e no simbolismo, privilegiando o singular e não o universal e, ao invés de explicar, compreende-se sua inteligibilidade no mundo local". Cabe salientar que a corrente humanista não se efetivou nas práticas escolares sólidas no ensino de Geografia, mas contribuiu para introduzir os conceitos de paisagem e lugar no processo de ensino-aprendizagem.

De acordo com Carvalho (2006) o trabalho com a Educação Ambiental deve contemplar três dimensões, que são elas: conhecimento, valores éticos e estéticos, e a participação política. Todavia, faz-se necessário evidenciar que tal proposta associa-se as Diretrizes Curriculares Nacionais (BRASIL, 2020), em seus 3 princípios norteadores, quais sejam:

a) Éticos (autonomia, responsabilidade, cooperação, respeito ao bem comum, ao meio ambiente, às diferentes culturas, identidades e singularidades);

b) Políticos (direitos de cidadania, criticidade, respeito à ordem democrática);

c) Estéticos (sensibilidade, criatividade, liberdade de expressão nas diferentes manifestações artísticas e culturais).

Os princípios norteadores da Educação Ambiental, sendo essa contemplada na presente pesquisa pela temática da atmosfera terrestre, estão associados diretamente aos valores que devem ser construídos durante a prática docente. Em especial, 
destacam-se os princípios éticos de autonomia, responsabilidade, cooperação e respeito ao bem comum. A autonomia foi contemplada durante a aula expositiva em que o aluno organiza os principais conteúdos a cerca das camadas atmosféricas e busca compreender a complexidade de seus fenômenos a partir de suas experiências. A responsabilidade, cooperação e respeito ao bem comum podem ser evidenciados durante a sequência didática.

A importância do conteúdo na Geografia Escolar é orientar quanto à problematizações realizadas diante da atmosfera, além de entender como ela se constitui, relacionando-a com seus principais fenômenos. Dessa forma, o aluno consegue compreender a relação dos fenômenos com a dinâmica da atmosfera.

De acordo com a Base Comum Curricular (BRASIL, 2020) o conteúdo proposto pertence aos estudos do $6^{\circ}$ ano do Ensino Fundamental, na unidade temática conexões e escalas a partir das relações entre os componentes físico-naturais. A habilidade correspondente preconiza descrever os movimentos do planeta e sua relação com a circulação geral da atmosfera, o tempo atmosférico e os padrões climáticos.

Para que os alunos possam descrever os movimentos do planeta, é necessário inicialmente conhecer os planetas do sistema solar, nomear os seus movimentos e relacioná-los com a circulação geral da atmosfera. Espera-se que o aluno possa reconhecer os elementos climáticos que interferem na circulação geral da atmosfera, como latitude, altitude, massas de ar, continentalidade, maritimidade, vegetação, relevo e correntes marítimas e urbanização, para compreender a influência sobre o clima.

A ação educativa verdadeira só pode ser vista como práxis que integra e reúne o diálogo. Conforme Kosik (1995), a ação educativa verdadeira salienta dois aspectos: o laborativo e o existencial, que se manifesta tanto com Franco (2001) quando se deixa de considerar o lado existencial, a práxis se perde como significado e permite ser utilizada como manipulação.

A compreensão dessa práxis foi ação transformadora do homem, como na formação da subjetividade humana. De fundamental para a caracterização dessa sequência didática. Kosik (1995) realça que a práxis é a esfera do ser humano, portanto, não é uma atividade prática contraposta à teoria, mas práxis "é determinação da existência como elaboração da realidade". 
Franco (2001) afirma que há uma intervenção pedagógica como instrumento de emancipação que considera a práxis como uma forma de ação reflexiva que pode transformar a teoria que a determina. Assim sendo, há uma unidade no movimento realizado pelo professor com seus alunos compreendido pela transformação de si, ao modificar a natureza com seu trabalho.

Nesse sentido, ao propor ações coletivas, músicas e a participação dos alunos frente a problematização dos fenômenos atmosféricos garante a reflexão crítica, sendo necessário ao professor mediar à construção do conhecimento, despertando em seu aluno, o interesse pela pesquisa e por novas técnicas para o desenvolvimento de suas habilidades. Cabe destacar que a ludicidade surge como uma alternativa para o desenvolvimento da cooperação, socialização, concentração, noções de espaço, raciocínio lógico e organização.

$\mathrm{O}$ ato de pensar geográfico, contextualizar espacialmente os fenômenos e a si mesmo, estabelecer relações entre as informações, por meio de procedimentos de estudo de um mapa, texto, tabela, fotografia são procedimentos que ativam as "funções psicológicas superiores" (processos mentais complexos de origem social), a capacidade de pensar conceitualmente sobre "o campo e agronegócio", isto é, pensar abstratamente este objeto de estudo permite que o aluno estabeleça relações entre estes dados e outros que ele já estudou ou teve contato (estabelecendo nexos mais fortes e mais complexos entre os conhecimentos).

A humanização é um processo que pode ocorrer em várias áreas, como nas Ciências Sociais, Ciências Humanas e Ciências Exatas. Quando ocorre tal manifestação, a humanização cria condições melhores e um pensamento coletivos para utilizadores de um sistema ou como nosso caso, de uma aprendizagem.

O processo de humanização implica a evolução do ser humano, pois ele tenta aperfeiçoar as suas aptidões através da interação com o seu meio envolvente. Para cumprir essa tarefa, os indivíduos utilizam recursos e instrumentos como forma de auxílio. A comunicação é uma das ferramentas de grande importância na humanização, exaltada na aula, é através dela que há o contato e a interação com os alunos. Ela correlaciona o conteúdo a forma de ser adquirido o conhecimento.

Um dos desafios contemporâneos da escola é contribuir para a formação moral e ética dos alunos-cidadãos. É fundamental que, nos espaços educativos, seja cons- 
truída e problematizada a participação do indivíduo na vida pública - o que demanda a consciência de realidades, conflitos e interesses individuais e sociais, o conhecimento de mecanismos de controle e defesa de direitos e a noção dos limites e das possibilidades de ações individuais e coletivas.

No caso do sistema atmosférico, a ideia de participação social é permanentemente construída. Primeiramente, na atmosfera a qual o aluno está inserido, exalta-se que há muitos elementos que as compõem, sendo assim a importância dada a cada individualidade ou fenômeno manifestado. Como na vida das pessoas e na sala de aula, em que cada um possui sua importância e deve ser ouvido.

Na relação professor e aluno, ao se aproximar dos alunos, perguntando-os se já viajaram de avião ou já observaram determinado dado atmosférico elevam-se as experiências individuais e a abstração. Desta forma, por meio desta exposição de situações-problema, as crianças e os jovens são convidados a refletir sobre a complexidade das relações e dos afetos e a elaborar estratégias de ação que envolva a todos, num ato de humanização.

Há vários caminhos para ensinar normas, valores e atitudes passíveis de (re)organizar as relações para uma convivência justa. $O$ trabalho educacional que mobiliza conteúdos atitudinais precisa estar nas ações cotidianas e fazer parte dos objetivos de aprendizagem. Diversas atividades pedagógicas, como a música e jogos levam a reflexões e ao entendimento crítico dos eventos que ocupam a vida na Terra.

A ação em projetos sociais ou socioambientais leva ao desenvolvimento da capacidade de cooperação e de argumentação com base na realidade. Como demonstrado na sala de aula, a problemática exemplificada pelo problema do efeito estufa, leva aos alunos a pensarem em conscientizar sobre o nosso futuro que está sendo construído de forma coletiva. A realidade e a aproximação dos conteúdos didáticos fazem com que percorra diferentes caminhos, incentivando a reflexão sobre novas possibilidades de obter uma humanização.

Conforme Martins (2013) o ensino escolar cumpre a tarefa de humanização dos indivíduos, a atividade de ensino conquista natureza específica na forma de educação escolar. A formação de conceitos é a base sobre a qual o psiquismo se desenvolve, conceitos cotidianos e de senso comum não incidem sobre o desenvolvimento psíquico da mesma maneira que os conceitos científicos. 


\section{RESULTADOS E DISCUSSÃO}

Nesta sequência didática serão abordados aspectos que fazem parte do trabaIho com uma das habilidades da ciência geográfica. A habilidade (EF06GE03) proposta pela BNCC contempla os movimentos do planeta e sua relação com a circulação geral da atmosfera, o tempo atmosférico e os padrões climáticos em sua totalidade. Durante essa sequência didática será contemplada a proposta parcial da habilidade, propondo continuidade em aulas prévias e subsequentes.

A sequência didática contemplará o conjunto de 4 aulas de 50 minutos cada cerca da atmosfera terrestre e seus fenômenos. Desse modo será caracterizado o conceito de atmosfera, as funções da atmosfera e suas camadas estruturantes, dentre os quais, destacam-se as diferenciações entre litometeoro e hidrometeoro. Portanto, será avaliado como os impactos provocados por catástrofes naturais ou mudanças nos componentes físico-sociais de um ecossistema afetam suas populações, provocando a alteração de hábitos, migração e catástrofes naturais.

O conteúdo abordado relaciona-se com o mecanismo natural do efeito estufa. Assim sendo, em segundo plano será realizado um debate no que tange o papel fundamental dos gases presentes na atmosfera, como o ozônio, para o desenvolvimento da vida na Terra. Será realizado um debate elevando argumentos para a reversão ou controle desse cenário com a temática: ações antrópicas responsáveis aumento artificial (queima dos combustíveis fósseis, desmatamento, queimadas etc.)

A atmosfera é considerada fundamental para a existência da vida na Terra. Com esta aula a relação entre a existência da atmosfera e a presença de vida na Terra será trabalhada de forma que os alunos percebam que as funções da atmosfera têm conexões com os seres humanos, mas que nem todas as funções têm relação com as sociedades. As duas primeiras aulas serão desenvolvidas no laboratório de informática pela utilização do projetor multimídia, que serão caracterizadas brevemente a seguir.

A aula iniciará com a exposição de imagens (Figura 1, 2 e 3) que relacionam com o cotidiano dos alunos, evidenciando fenômenos pertencentes à atmosfera terrestre. Dessa forma, as evidências empíricas presentes no cotidiano dos alunos serão resgatadas para compreender a problematização proposta durante a aula expositiva. 
Figura 1 - Aula expositiva sobre atmosfera: a interrelação de fenômenos atmosféricos com a dinâmica populacional cotidiana.

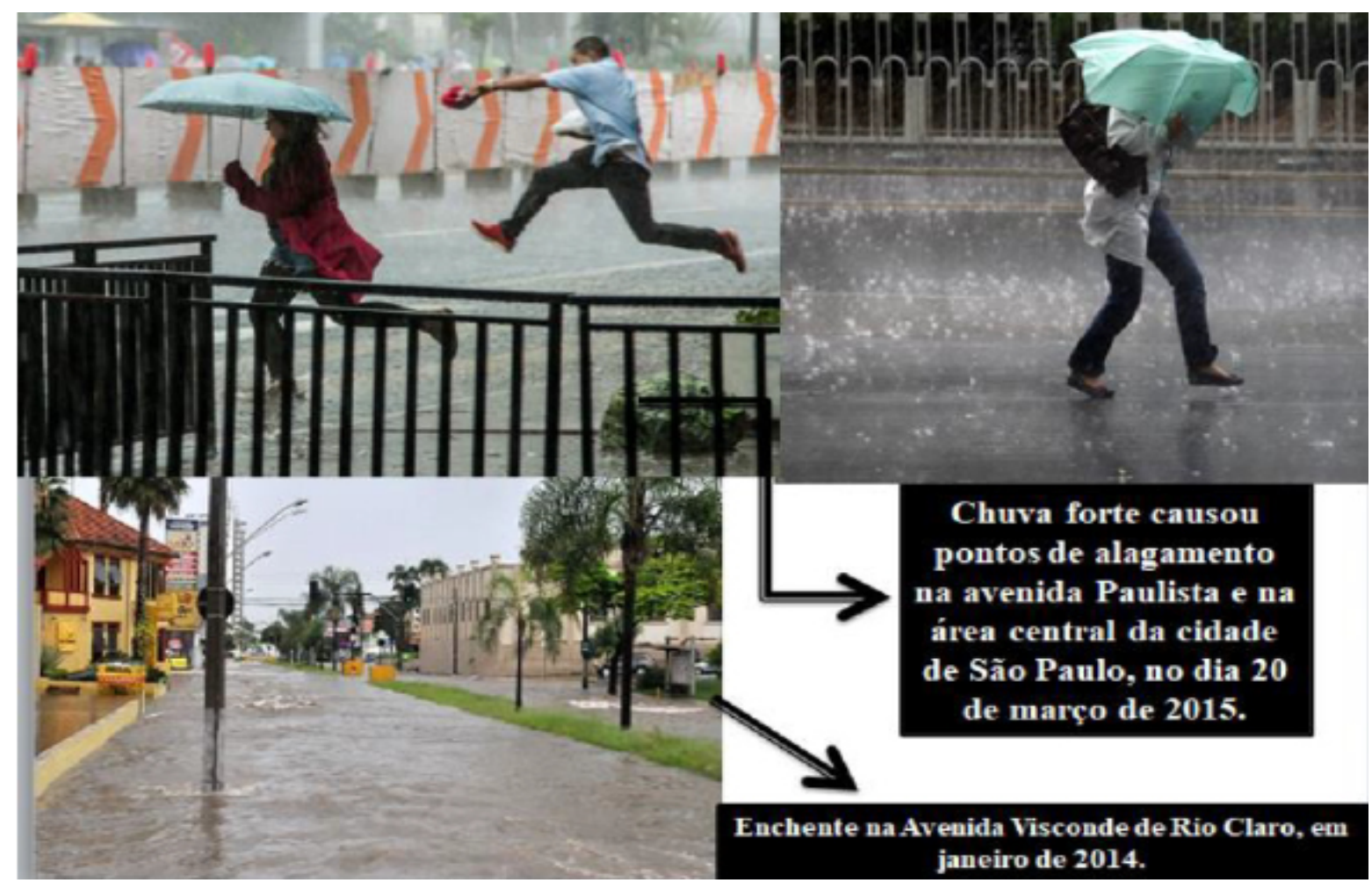

Fonte: Acervo particular do autor (2020).

Figura 2 - Aula expositiva sobre atmosfera: a interferência das precipitações no cotidiano dos alunos

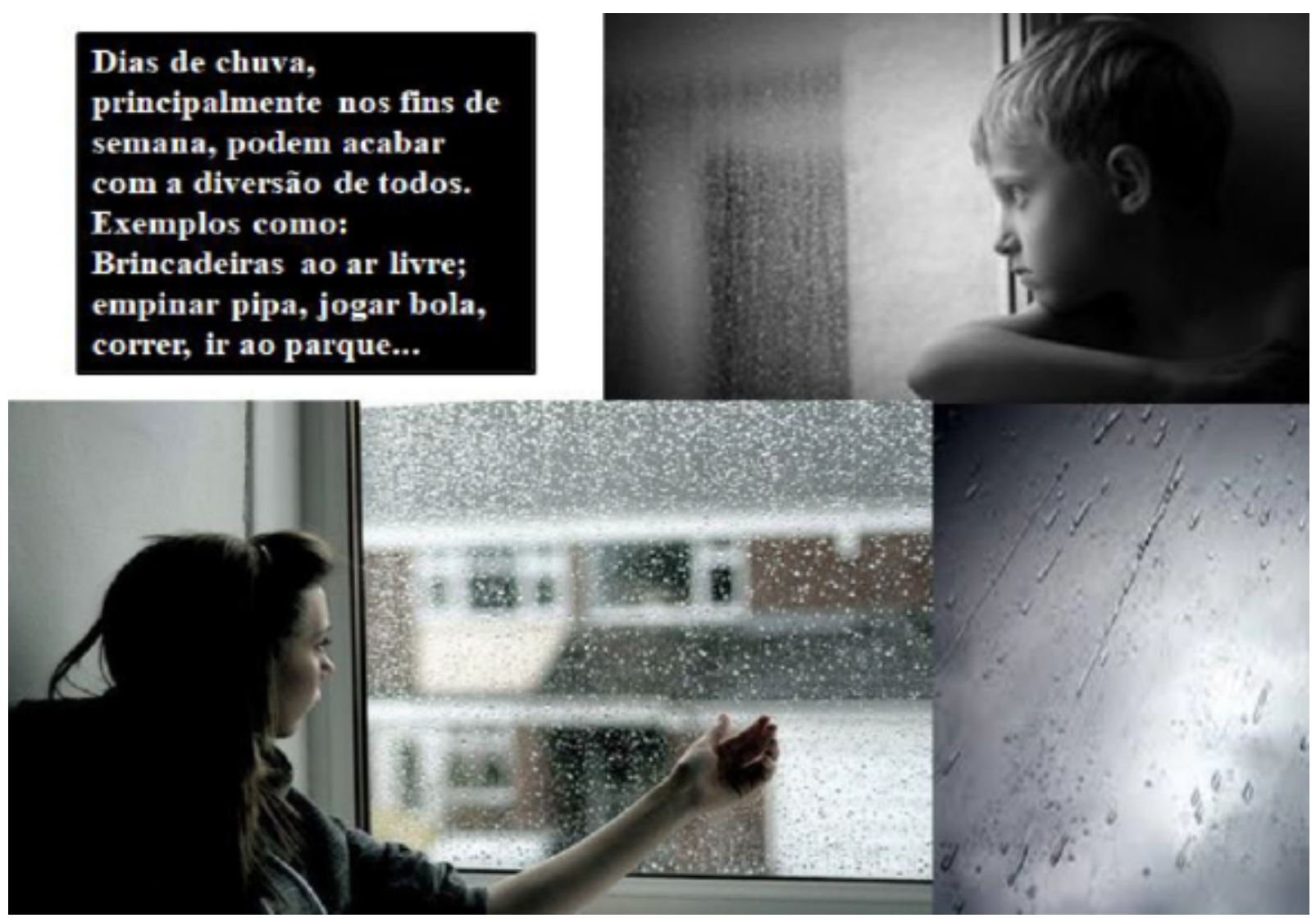

Fonte: Acervo particular do autor (2020). 
Figura 3 - Aula expositiva sobre atmosfera: fenômenos atmosféricos presentes na Troposfera.

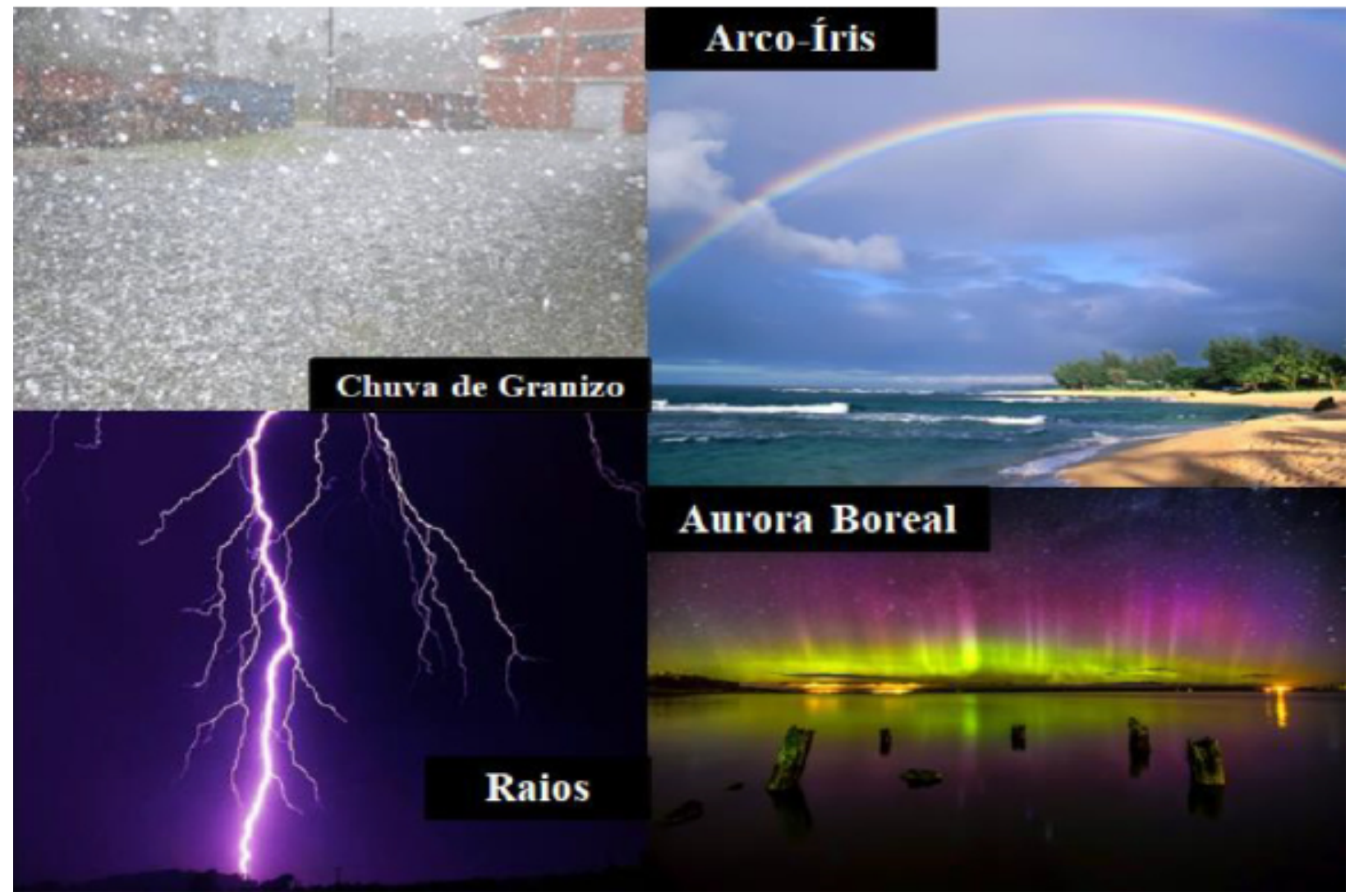

Fonte: Acervo particular do autor (2020).

Após a observação das imagens será exaltado uma questão-problema aos alunos, qual seja: alguém já passou por alguma dessas situações ou viu algum fenômeno passado anteriormente? A partir das respostas obtidas pelos alunos, será realizada a introdução dos principais conceitos da sequência didática no que tange atmosfera terrestre, quais sejam:

1. Atmosfera é uma camada gasosa que envolve o nosso planeta, acompanhando-o em todos os seus movimentos. (Conceito)

2. Ela pode ser considerada uma capa que protege a Terra de efeitos como a radiação e ajuda o nosso planeta a manter a temperatura mais amena. (Função)

3. É dividida em cinco camadas, de acordo com suas diferenças. Troposfera, Estratosfera, Mesosfera, Termosfera e Exosfera. (Estrutura)

Os principais conceitos serão aprofundados segundo a literatura contemporânea da Geografia, já descritos anteriomente no primeiro subtítulo do artigo. Destaca-se nesse sentido, cada camada atmosférica terrestre será apresentada com sua respectiva a temperatura, altitude, composição, fenômenos e imagens ilustrativas. 
Posteriormente, será realizada uma contextualização sobre a camada de ozônio e elaborado um mapa conceitual sobre o efeito estufa. Segundo Ricarte e Carvalho (2011, p.265) os mapas conceituais constituem-se ferramentas indispensáveis para a construção hierárquica e associativa do conhecimento nas várias áreas do conhecimento. As diversas associações são realizadas através de representações gráficas semelhantes aos diagramas das redes semânticas, onde o professor e o aluno podem construir seu conhecimento e representá-lo por diagramas e palavras conectadas por frases de ligação. O mapa conceitual desenvolvido contribuirá para o debate sobre a importância do ozônio na atmosfera terrestre e para a diferenciação entre a ação natural do fenômeno e seu agravamento realizado pela ação antrópica, conforme a Figura 4. Portanto, a sala será dividida em dois grandes grupos, o primeiro será responsável por exaltar argumentos que defendam o efeito estufa por causa natural e o segundo contribuirá no debate no que tange o fenômeno agravado pelo ser humano.

Figura 4 - Mapa conceitual acerca da atmosfera terrestre com ênfase no efeito estufa.

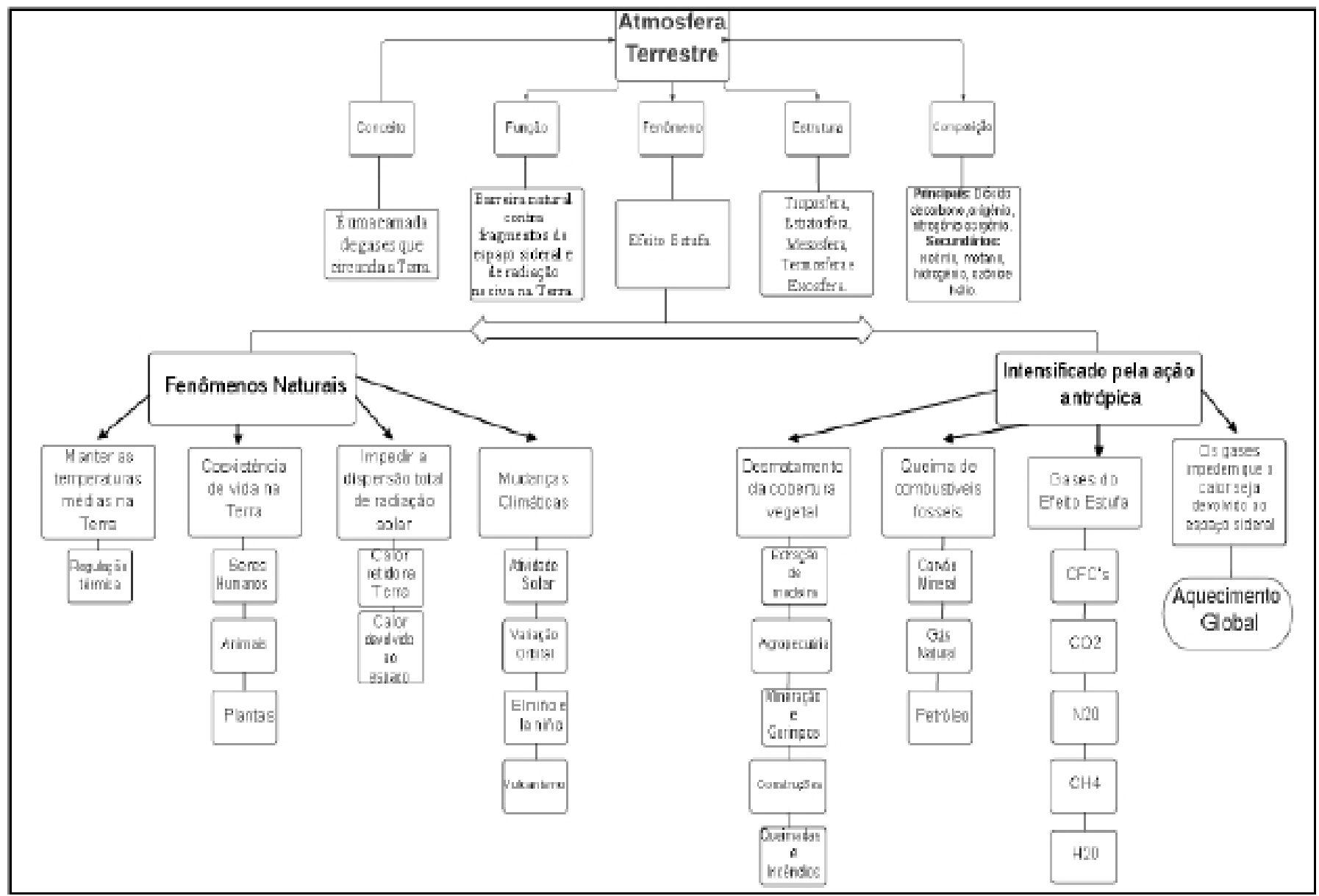

Fonte: Acervo particular do autor (2020). 
Após o encerramento do debate, a sequência didática continuará com mais duas aulas de 50 minutos que serão caracterizadas a seguir. A primeira aula será contemplada com uma revisão dos conceitos a cerca da atmosfera terrestre e seus fenômenos. Para isso, será utilizada uma paródia musical como suporte ou subsídio para a memorização e para o aprendizado da aula anterior proposta.

Vieira e De Sá (2013, p. 107) reforça este pensamento afirmando que "o espaço musical precisa ser explorado de forma que os sentidos da audição, da visão e do corpo sejam integrados para ver e sentir o espaço". O ver e sentir o espaço aproxima o conhecimento de mundo presente do fazer geográfico aos alunos que antes estavam desavisados da conexão entre a disciplina e a realidade, simultaneamente material e abstrata. Analisando a etapa inicial do trabalho musical na escola, uma característica importante, ocasionada ao ouvir-se uma música, é a memorização.

Já entendido que o aprendizado pode acontecer por meio de músicas, outra característica importante no trabalho com ela é a interação dos alunos entre si e com o professor, estimulando suas estruturas emocionais e sociais. Conforme Ferreira (2012) professores inserem a música nos ambientes escolares, associadas às mais variadas disciplinas para auxiliá-los no processo de ensino-aprendizagem de seus educandos. Sendo assim, foi criada uma composição de minha autoria no que tange o conhecimento das camadas atmosféricas, segue abaixo a letra completa da música.

"A Exosfera é a camada antes do espaço sideral,

E lá é onde está o satélite artificial,

Por causa da altitude, o ar é rarefeito,

fazendo a camada ser desse jeito,

Já a Termosfera é afetada pela radiação

E é nela que ocorrem a transmissão de rádio e televisão,

Ela é a penúltima camada da atmosfera

$E$ devido a radiação também é chamada de lonosfera

Agora vou falar como a mesosfera se configura

Em seu limite se encontra a mais baixa temperatura

Ozônio e vapor de sódio uma parte dela tem

$\mathrm{E}$ os fenômenos luminosos como as auroras, ela contêm.

Por causa da camada de ozônio, a estratosfera absorve ultravioleta 
O que ajuda a manter a temperatura do nosso planeta

Nessa camada também se encontram os balões sonda

Que fazem várias medições e pelo planeta ele ronda.

$\mathrm{Na}$ Troposfera, falando da sua composição

É nela que se encontra chuva, nuvens, efeito estufa e o avião

Alguns de seus fenômenos transformam a vida da gente No espaço urbano, as chuvas fortes podem causar várias enchentes".

Fonte: As camadas atmosféricas. Composição do autor (janeiro de 2020).

Durante a aula, a letra da música será entregue aos alunos para que eles possam canta-la. Com o auxílio de uma caixa de som será reproduzido uma harmonia de hiphop para auxiliar a composição criada. Contudo, a organização da aula proposta com recursos e linguagens variadas, tendo como ponto central a música, contribuirá para a diversificação da rotina escolar dos alunos construindo momentos significativos de aprendizagem.

\section{CONCLUSÃO}

A sala de aula é um espaço ao qual ocorrem as múltiplas determinações decorrentes de práticas pedagógicas. Tais práticas foram mediadas pela utilização de métodos, quais sejam: positivista, fenomenologia e materialismo histórico-dialético. O método é a construção teórica que envolve a interpretação e a demonstração, sendo ele indutivo e/ou dedutivo. Nesse cenário pode-se considerar o objeto como centralidade que o sujeito quantifica ou até mesmo, o sujeito e sua percepção sobre a realidade.

Para entender os problemas, construíram-se categorias de análise determinadas pelo ser social. Desse modo, deve-se analisar o sujeito em seu contexto e nunca de forma isolada. As teorias pedagógicas caminharam através de distintos aspectos de transmissão e concepção do conhecimento, instrumentos e centralidade para que os alunos passem pelo processo de humanização.

A realidade concreta da vida dos indivíduos é o ponto fundamental para toda e qualquer investigação. Nesses termos, chega-se à conclusão de que as práticas 
pedagógicas que respeitem a concepção de aprendizagem em foco devem apoiar-se em duas verdades fundamentais: que o conhecimento provém da prática social e a ela retorna; e ainda que o conhecimento seja um construído pelo diálogo no coletivo, nenhum conhecimento é produzido na solidão do sujeito.

As práticas pedagógicas deverão se reorganizar e se recriar a cada dia para dar conta do projeto inicial que é a humanização dos sujeitos. Dessa forma foi retratada no presente artigo uma sequência didática que exalta a realidade vivida pelo aluno, passando pelo processo de significado, significante e sentido, onde os princípios norteadores (éticos, políticos e estéticos) pudessem ser atingidos.

O papel do professor é fundamental no desenvolvimento da criticidade de seus alunos, que para atingi-la, deverá passar por três níveis de reflexão: a técnica, a prática e a crítica. Assim sendo, as ações explícitas, o conhecimento prático e análise política da prática pedagógica são instrumentos capazes de acompanhar e transformar a sociedade contemporânea, esta contextualizada por cada aluno em uma sala de aula.

A prática pedagógica exercida nessa sequência didática traduz a preocupação de um professor reflexivo que busca conduzir seus alunos a uma prática significativa na Geografia e que enseja a partir do ensino relacionar aprendizagem e desenvolvimento.

\section{REFERÊNCIAS}

BRASIL. Base Nacional Comum Curricular (BNCC). Brasília, MEC/CONSED/ UNDIME, 2020.

CARVALHO, L. M. A temática ambiental e o processo educativo: dimensões e abordagens. In: CINQUETTI, H. S.; LOGAREZZI, A. (Orgs.). Consumo e resíduos: fundamentos para o trabalho educativo. São Carlos: Edufscar, 2006, p. 19-41.

CAVALCANTI, L. de S. Cotidiano, mediação pedagógica e formação de conceitos: uma contribuição de Vygotsky ao ensino de Geografia. Caderno Cedes, Campinas, vol. 25, n. 66, p. 185 - 207, maio/ago. 2005.

CORRÊA, R. L. Espaço: um conceito-chave da Geografia. In: CASTRO, Iná Elias; GOMES, Paulo César da Costa; CORREAA, Roberto Lobato (Orgs.). Geografia: conceitos e temas. $2^{\mathrm{a}}$ ed. Rio de Janeiro: Bertrand Brasil, 2000. 
FERREIRA, M.N. A música como recurso didático na aula de Geografia. Monografia - Universidade de Brasília-UNB: Brasília, 2012.

FRANCO, M.A.S. A pedagogia como ciência da educação: entre práxis e epistemologia. Tese (Doutorado em Educação) - Faculdade de Educação da Universidade de São Paulo, São Paulo, 2001.

GONCALVES, A. R. Contribuições da teoria histórico-cultural ao ensino e aprendizagem da Geografia. Estudos Geográficos, Rio Claro, 16(1) 213-224, jan./jun. 2018.

KOSIK, K. Dialética do concreto. 6. ed. Rio de Janeiro: Paz e Terra, 1995.

MARTINS, L. M. O papel da educação escolar no desenvolvimento psíquico. In: O desenvolvimento do psiquismo e a Educação Escolar: contribuições à luz da psicologia histórico-cultural e da pedagogia histórico-crítica. Campinas (SP): Autores Associados. 2015. P.269-308.

MARTINS, L. M. Os fundamentos psicológicos da Pedagogia histórico-crítica e os fundamentos pedagógicos na psicologia histórico-cultural. Germinal: Marxismo e Educação em Debate, Salvador, v.5, n.2, p.130-143, dez. 2013.

RICARTE, D. B.; CARVALHO, A. B. G. As novas tecnologias da informação e comunicação na perspectiva do ensino de Geografia. In: SOUSA, R. P., MOITA, F. M. C. S. C., CARVALHO, A. G. (Orgs.). Tecnologias digitais na educação. Campina Grande: EDUEPB, 2011. P. $259-274$.

SANTOS, M. Técnica, espaço, tempo: globalização e meio técnico-científico-informacional, Hucitec, São Paulo, Brasil, 1997.

VIEIRA, C. E; SÁ, M. G. de. Recursos didáticos: do quadro-negro ao projetor, o que muda? In. PASSINI, E. Y; PASSINI. R; MALYSZ. S. T, (Organizadores). Prática de ensino de geografia e estágio supervisionado. São Paulo: Contexto, 2007.

ZEICHNER, K. M.; LISTON, D.P. Teaching student teachers to reflect. Harvard Education Review. 56 (1), 1987, p. 23-48. 


\title{
A LINGUAGEM DOS QUADRINHOS
}

\author{
NA SALA DE AULA: \\ ENSINAR E APRENDER \\ GEOGRAFLA COM AS HQS
}

\section{VINICIO LUISS PIEROZAN \\ VANESSA MANFIO} deral do Rio Grande do Sul (POSGeałUFRGS) e graduado em Geografia pela mesma instituição. Professor da Rede Municipal de Ensino de Canoas, RS. E-mail de contato: vpierozan@hotmail.com 2 Doutora em Geografia pelo Programa de Pós-Graduação em Geografia da Universidade Federal do Rio Grande do Sul (POSGea/UFRGS). Mestre em Geografia e graduada/em Geografia pela Universidade Federal de Santa Maria (UFSM). Professora da Escola Municipal de Ensino Fundamental Cândida Zasso no município de Nova Palma, RS e pesquisadora do Núcleo de Estudos Agrários da UFRGS. E-mail de contato: vamanfio@hotmail.com 


\section{O COMEÇO DE TUDO}

O ensino de Geografia envolve o aprendizado, o entendimento e busca a compreensão da relação constituída entre a sociedade e a natureza, a partir das suas diferentes e diversas interconexões estabelecidas, e para tal, a Geografia se utiliza de vários conceitos geográficos para compreender o espaço geográfico, seu objeto de estudo. Portanto, a Geografia deve estar mergulhada no cotidiano do aluno, como, por exemplo, através do rio que corre seu leito normal, da cidade que vibra no seu fluxo diário de pessoas e mercadorias, da localização no/do e para o espaço e as diferentes relações estabelecidas sendo ao homem visíveis ou invisíveis, ou seja, "respira-se" Geografia em todos os lugares. Conforme Kaercher (1996, p. 109) "[...] a Geografia existe desde sempre e nós a fazemos diariamente". "[...] afinal, a Geografia é o cotidiano, é a paisagem, é a relação entre os sujeitos, e estes com os lugares, entre tantas outras variações possíveis." (CASTROGIOVANNI, et al., 2011, p. 22).

Mesmo assim, o ensino de Geografia, muitas vezes, não tem deixado transparecer essa Geografia do cotidiano, presente na vida diária e no modo de ser das pessoas, pelo contrário, há currículos escolares, práticas pedagógicas e recursos didáticos que reforçam a transmissão de conceitos e objetos de conhecimento já prontos, datados, desorganizados, sem conexão entre eles e com o "mundo do aluno", parados no tempo, deixando o ensino e a sala de aula desinteressante, desestimulante e sem sentido para muitos estudantes. "Nesta visão, distorcida de educação, há pouco espaço para criatividade, para transformações; parece não haver saber, já que o saber só existe na invenção e na reinvenção, nas descobertas que mulheres/ homens fazem no mundo." (CASTROGIOVANNI, et al., 2011, p. 20, grifo dos autores). A Geografia, por sua vez,

[...] deve se pautar, portanto, pela compreensão dos processos e não na enfadonha forma classificatória. A forma classificatória é conservadora, pois não busca a compreensão dos processos. Compreender os processos, por sua vez, é tomar por base a análise objetiva, aprender o conjunto das conexões internas, com suas tensões, seus conflitos; sua gênese, o seu desenvolvimento e as suas tendências. (CASTROGIOVANNI, et al., 2011, p. 19, grifos dos autores) 
Existem linguagens que são importantes para a construção e o aprimoramento do processo ensino-aprendizagem escolar. Estas linguagens levam em consideração o desenvolvimento e a participação ativa do aluno, como, por exemplo, as Histórias em Quadrinhos (HQs). Elas auxiliam na construção/reconstrução do conhecimento e utilizam-se do lúdico para entreter os educandos, especialmente os da Educação Básica (Ensino Fundamental e Ensino Médio). Assim, o aluno aprende brincando e interagindo de uma maneira mais divertida e prazerosa com o material escolar e a aula construindo o conhecimento e desconstruindo padrões, tendo em mente que, “[...] ensinar não é transferir conhecimento, mas criar as possibilidades para sua produção ou a sua construção" Freire (1997, citado por CASTROGIOVANNI, et al., 2011, p. 66, grifos dos autores).

Pensando nisso, este capítulo busca analisar o ensino de Geografia por meio da utilização da linguagem das HQs como recurso didático, demonstrando uma prática pedagógica aplicada com alunos do sétimo ano do Ensino Fundamental na Escola Municipal de Ensino Fundamental Professor Thiago Wurth, localizada no Bairro Mathias Velho, município de Canoas, estado do Rio Grande do Sul (Figura 1). Uma versão desse estudo foi apresentada no X Fórum Nacional NEPEG ${ }^{3}$ de Formação de Professores de Geografia, realizado entre os dias 7 e 11 de dezembro de 2020.

A prática didática foi realizada durante o segundo trimestre do ano letivo de 2019, no período compreendido, entre os dias 27 de maio e 23 de setembro. Os objetos de conhecimento do componente curricular Geografia abordados durante a prática pedagógica foram os seguintes: formação territorial do Brasil; características da população brasileira; produção circulação e consumo de mercadorias.

$3 \quad$ Núcleo de Ensino e Pesquisa em Educação Geográfica. 
Figura 1 - Localização da EMEF Professor Thiago Wurth, Canoas RS

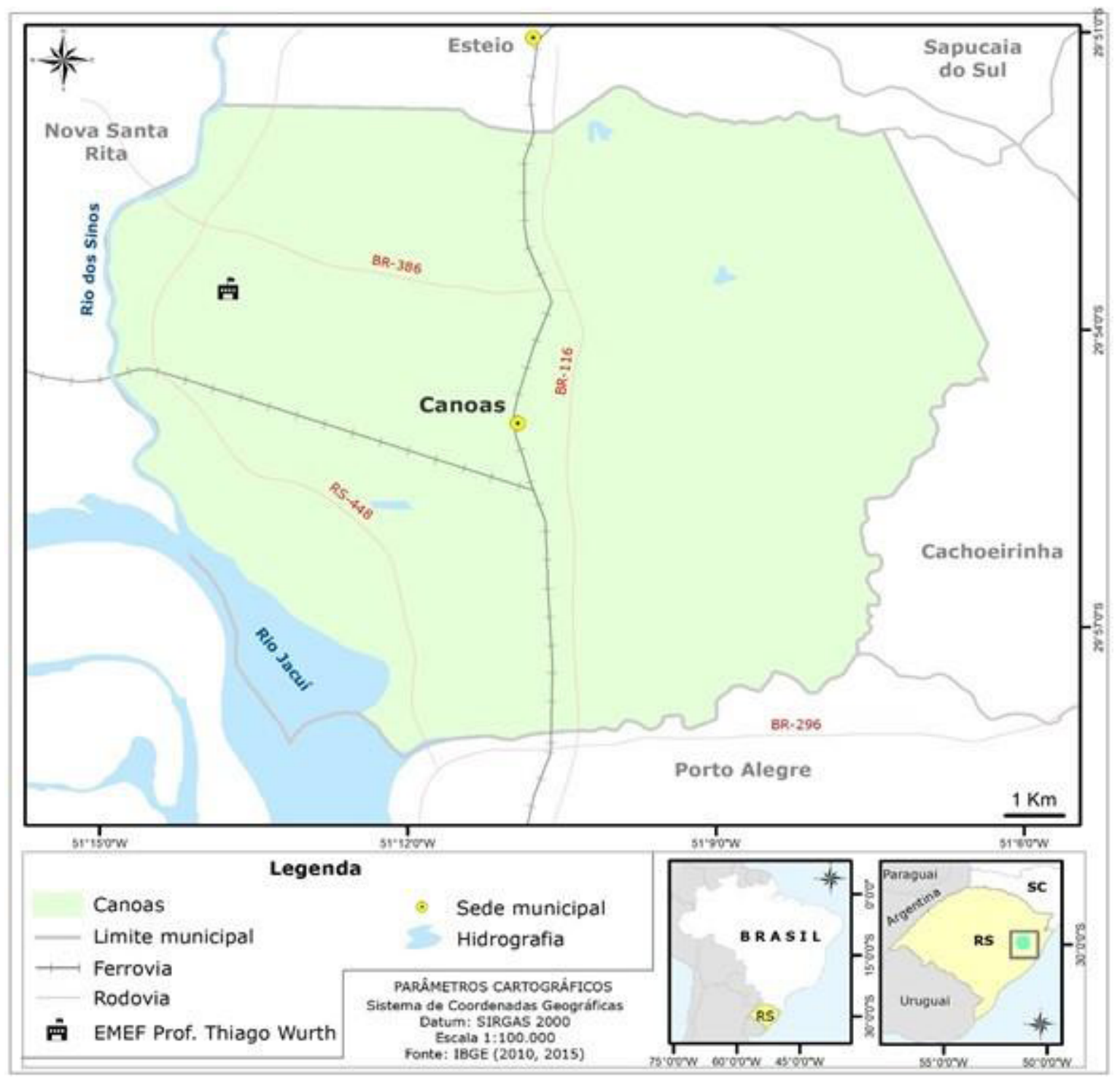

Fonte: Pierozan (2020, p. 939).

Quanto ao método utilizado para ministrar as aulas destaca-se o construtivismo, onde o aluno é sujeito ativo do seu ensino. Logo, o estudante tem poder para observar, criar, ressignificar, decodificar, ou seja, dialogar com os diferentes objetos do conhecimento que estão sendo trabalhados em sala de aula. O construtivismo de acordo com Becker (1993, p. 88) significa:

[...] a ideia de que nada, a rigor, está pronto, acabado, e de que, especificamente, o conhecimento não é dado, em nenhuma instância, como algo terminado. Ele se constitui pela interação do indivíduo com o meio físico e social, com o simbolismo humano, com o mundo das relações sociais.

Ao final, espera-se com este trabalho contribuir para as discussões que envolvem o ensino de Geografia, demonstrando novas possibilidades práticas de construir 
uma Geografia escolar mais comprometida com a necessidade de aprender do aluno, trazendo este para o centro do processo ensino-aprendizagem, como locutor e ator do seu conhecimento, ou seja, o estudante como protagonista desse processo, a partir de uma maneira mais leve e prazerosa para com o saber escolar trabalhado em sala de aula.

\section{ENSINAR E APRENDER GEOGRAFIA ATRAVÉS DA LINGUAGEM DAS HISTÓRIAS EM QUADRINHOS}

O ensino de Geografia precisa criar e proporcionar diferentes situações em sala de aula e fora dela também, que favoreçam a aprendizagem, onde o aluno possa aprender a ressignificar os objetos de conhecimento que estão sendo propostos e possibilite compreender o mundo a sua volta a partir de diferentes releituras geográficas. Para isto, é importante que o professor rompa "[...] com aquela visão de que Geografia é algo que só veremos em aulas de Geografia" (KAERCHER, 1996, p. 109), que é normalmente centrada nos objetos de conhecimento e na exposição de conceitos e temas, que muitas vezes são trabalhados de maneira isolada e descontextualizada da realidade vivida dos estudantes. Em relação aos objetos de conhecimento nunca é demais lembrar que, "[...] os conteúdos são instrumentos e a escolha desses instrumentos vai depender de sua utilidade para os alunos." (CAVALCANTI, 2002, p. 14).

É importante mencionar que a ideia tradicional de ensinar ainda é bastante presente em grande parte das escolas de Educação Básica existentes no país. Nesse sentido, importa passar a buscar e utilizar outros caminhos, que sejam menos "tortuosos" para o ensino de Geografia, ou seja, que possibilitem que os alunos consigam aprender sozinhos, desenvolvam autonomia, construindo o conhecimento e superando paradigmas com o intermédio do professor, a partir de recursos didáticos, e/ou materiais preparados para essa finalidade que os envolvam por completo com o aprendizado, pois ambos estão ensinando e aprendendo ao mesmo tempo, é uma via de mão dupla, essa relação deve se estruturar num patamar de horizontalidade (igualdade). É um processo de constante crescimento e amadurecimento, e nessa perspectiva "[...] educar é interagir, dialogar e investigar [...]" (CASTROGIOVANNI, et 
al., 2011, p. 21), esse processo deve se dar/desenvolver sem amarras.

Nesse sentido, as $\mathrm{HQs}$ têm trazido à tona muitos assuntos geográficos atuais presentes na mídia e no cotidiano dos alunos, além de serem uma linguagem que os estudantes se interessam, inclusive o aluno que possa se sentir mais desmotivado sempre tem em casa presente no jornal, ou no acesso facilitado pela internet algum post na rede social que habitualmente mais utiliza para se entreter, ou até mesmo a possibilidade de retirar na biblioteca da escola esse material, pois as crianças/adolescentes são atraídas à leitura dos quadrinhos e à ação dos diferentes personagens escritos em historinhas bastante familiares. Segundo Melo, Medeiros e Silva (2013), "Os quadrinhos atraem um público distinto pelo fato de serem oriundos do conjunto de duas artes diferentes - escrita e desenho".

As crianças se interessam por histórias em quadrinhos desde pequenas, já que elas próprias se utilizam de desenhos e garatujas para se conectar com o mundo, e na adolescência as cores, os símbolos e a forma de diálogo dos quadrinhos são interessantes da mesma forma no processo de ensino, pois elas permitem uma leitura prazerosa (COSTA, 2011). Porém, é importante ter o conhecimento que

[...] a relação entre quadrinhos e educação nem sempre foi amigável, passando por momentos de grande hostilidade e outros de tímida cumplicidade, quando alguns professores mais ousados se atreveram a utilizá-los em sala de aula. Tratava-se de aplicações esporádicas, marcadas muito mais pela ousadia e entusiasmo de seus propositores do que propriamente por correção metodológica. (SANTOS; VERGUEIRO, 2012, p. 82)

Atualmente, os quadrinhos são uma presença constante em livros didáticos do Ensino Fundamental e Médio, figuram com frequência também em provas de concursos vestibulares, Exame Nacional do Ensino Médio (Enem) e no Exame Nacional de Desempenho dos Estudantes (Enade), ou seja, as potencialidades pedagógicas das HQs já são reconhecidas e amplamente aceitas, aliás, já estão presentes em todas as etapas da Educação Básica e até o nível da Educação Superior.

Particularmente, a Geografia, a inscrição geográfica, ou seja, a grafia da superfície da Terra, no ensino de Geografia, pode ser feita por meio de diferentes desenhos e também por outras representações Cosgrove (2008 citado por COSTA, 2012). Complementando o exposto anteriormente citado, Deffune (2010, p. 158), salienta 
que:

$\mathrm{Na}$ Geografia, a imagem é a ferramenta básica de representação e comunicação. A sua inclusão, na sala de aula, aumenta a motivação dos estudantes para o conteúdo das aulas, ao aguçar a curiosidade e desafiar o senso crítico, além de preparar o aluno para a linguagem geográfica.

Nesse ponto de vista, percebe-se que, os instrumentos representativos são extremamente importantes no processo ensino-aprendizagem, já que por meio deles é possível a exploração, facilmente, de uma quantidade significativa de diferentes objetos de conhecimento, que talvez não fossem tão bem explorados com o auxílio de um texto escrito, simplesmente porque se faz pelo lúdico, pelas imagens, pelos signos que carregam consigo e transmitem uma mensagem a ser decodificada (ROHDE, 2012). Embora, nas escolas, em sua maioria, ainda persista a ideia de que o texto escrito passa maior credibilidade enquanto linguagem a ser trabalhada em um determinado tema.

Mas, Severo e Manfio (2013, p. 286) afirmam que, "[...] as representações são importantes recursos que o professor pode utilizar para trabalhar com vários temas e conceitos com os alunos em sala de aula, podendo até mesmo trabalhar com o espaço vivido dos mesmos". Nerys e Freitas (2018, p. 326) reforçam esse entrosamento ao destacar que "[...] as histórias em quadrinhos estão sempre representando o espaço das mais variadas maneiras e com isso trazem diversos elementos a serem abordados". O espaço da cidade, do campo, da natureza, da cartografia, enfim são muitos os espaços retratados pelos quadrinhos e que trazem consigo a discussão dos temas de interesse da Geografia, tais como: a questão ambiental, a questão social, a questão política, as questões de gênero, a xenofobia, a globalização, a alfabetização cartográfica, a migração e a conjuntura econômica verificada nos mais diferentes e longínquos lugares e escalas geográficas.

As HQs são a representação do real dentro do fictício, pois retratam vários problemas e situações presentes no dia a dia das pessoas, sendo muitos desses assuntos temas de estudo e de pesquisas na Geografia. Como afirmam Nerys e Freitas (2018, p. 326), “As histórias em quadrinhos nos remetem a diferentes ambientes e contextos sociais, políticos e culturais, tendo como ponto de vistas problemas, anseios e curiosidades de um mundo fantástico, ficcional, mas pautado em muitos dile- 
mas reais". Além disso, as HQs auxiliam na construção de um olhar capaz de distinguir e dar sentido as imagens presentes no cotidiano, pela interpretação de diálogos e imagens e pela leitura do contexto onde a história se passa (COSTA, 2012). Elas auxiliam no sentido de fazer o aluno pensar e criar um senso crítico e interpretativo sobre o que lê e observa.

O grande poder das HQs encontra-se no que Testoni e Adib (2003), destacam como objetivo primordial desse recurso, a utilização de uma linguagem em catarse responsável pela redução do stress do educando/leitor e germinadora de atividades mentais e cognitivas entre a narrativa e o expectador. Portanto, a utilização das HQs em sala de aula se mostra relevante pelos seguintes motivos: a) ampliar a capacidade de observação e expressão; b) reporta ao estímulo do senso de humor e da leitura crítica; c) reforça a necessidade de correlação da mensagem verbal e não verbal, assim como da cultura informal e formal; d) aproximação das informações científicas, artísticas e históricas com o universo social do aluno (DEFFUNE, 2010, p. 160).

Logo, a linguagem dos quadrinhos pode ser utilizada com bastante eficácia nas diferentes etapas da Educação Básica, desde a Educação Infantil, anos iniciais (1 ${ }^{\circ}$ ao $5^{\circ}$ ano), e nos anos finais ( $6^{\circ}$ ao $9^{\circ}$ ano) do Ensino Fundamental, até o Ensino Médio, basta o professor escolher as HQs, que são melhores adequadas para as diferentes faixas etárias e níveis de maturidade intelectual das crianças e/ou adolescentes. Sem contar, que é um recurso bastante acessível e de fácil acesso, afinal, estão disponíveis gratuitamente na internet, cadernos de jornais, revistas ou em livros (Gibis) encontrados facilmente nas bibliotecas das escolas e livrarias.

A utilização das HQs não tem uma regra e/ou limite definido, depende da criatividade do docente e da sua relação e diálogo com os objetos de conhecimento que serão trabalhados em sala de aula, bem como, precisa ser levado em conta à idade e às características dos alunos, sendo as HQs utilizadas para introduzir temas, exemplificar e mesmo finalizar conteúdos didáticos (COSTA, 2011). Dessa forma, as HQs não são uma linguagem a ser puramente posta em aula, mas deve ser relacionada e inserida aos objetos de conhecimento, com uma exploração prévia do docente e de uma criação de objetivos e resultados para serem percorridos com o uso desse material, respeitando o nível de maturidade dos alunos. Os quadrinhos podem ser utilizados nas aulas presenciais e não presenciais desde que seja feito um acompa- 
nhamento, com uma orientação e fundamentação da atividade e do material a ser utilizado, principalmente porque nos dias de hoje existe uma infinidade de HQs que se relacionam com os diferentes campos do saber, para além da Geografia.

Ainda, o trabalho com HQs pode suscitar a própria criação dos quadrinhos pelos alunos, resultando num trabalho autoral, a partir de um tema gerador, objeto de conhecimento, conceito, que foi discutido/trabalhado em sala de aula, de uma reportagem e/ou até mesmo de uma Fake news. Essa construção também costuma ser empolgante, desafiante, educativa, criativa e serve inclusive como processo avaliativo da aprendizagem do estudante no que concerne ao entendimento/compreensão dos objetos de conhecimento ministrados nas aulas de Geografia. As HQs no ensino de Geografia, não estão restritas a visualização das paisagens e imagens, mas são fontes de leitura do texto e símbolos (VERGUEIRO, 2010).

Desse modo, as HQs podem servir como recurso pedagógico auxiliar e motivacional para o aprendizado dos objetos de conhecimento da Geografia, podendo ser utilizada também na preparação de uma aula mais criativa, participativa e instigante para os alunos (COSTA, 2012). É importante ressaltar que quando o estudante está motivado a aprender esse processo acontece automaticamente, de forma espontânea, permitindo uma maior participação e interação dos alunos durante as atividades realizadas em sala de aula e fora dela também, na realização de atividades de campo, por exemplo.

\section{A GEOGRAFIA A PARTIR DA LINGUAGEM DAS HQS NOS ANOS FINAIS DO ENSINO FUNDAMENTAL}

Os quadrinhos entraram nas aulas do componente curricular de Geografia no sétimo ano, por meio da realização de oficinas pedagógicas. As oficinas foram aplicadas na turma $7 \mathrm{C}$, composta por 28 alunos regularmente matriculados, com faixa etária que oscilava entre 12 e 14 anos de idade. A temática das atividades foi escolhida conforme os objetos de conhecimento que a turma estava estudando no transcorrer do segundo trimestre do ano letivo. Dentre as práticas realizadas durante as oficinas selecionamos uma para ilustrar as potencialidades das HQs em auxiliar no processo ensino-aprendizagem dos diferentes temas, objetos de conhecimento e construção dos conceitos geográficos. 
Neste ponto, a HQ (Figura 2), serviu para introduzir os objetos de conhecimento em uma aula referente à temática que contemplava o meio urbano e o meio rural. A oficina considerava a temática que era objeto de estudo naquele momento específico do planejamento do professor de Geografia. Logo, os estudantes que receberam a $\mathrm{HQ}$ foram tomados pela curiosidade, pelo interesse em realizar a leitura, foi observado uma "satisfação/prazer" em ler/interpretar a HQ a partir da perspectiva geográfica, como conhecimento, saber prático presente em seu cotidiano, em suas mais variadas vivências. A aula passou a ser vista como "útil" para os alunos, pois teve significado aos estudantes e possibilitou a construção do conhecimento escolar a partir de uma linguagem já bastante presente no dia a dia dos alunos.

Figura 2 - Diferença entre campo e cidade

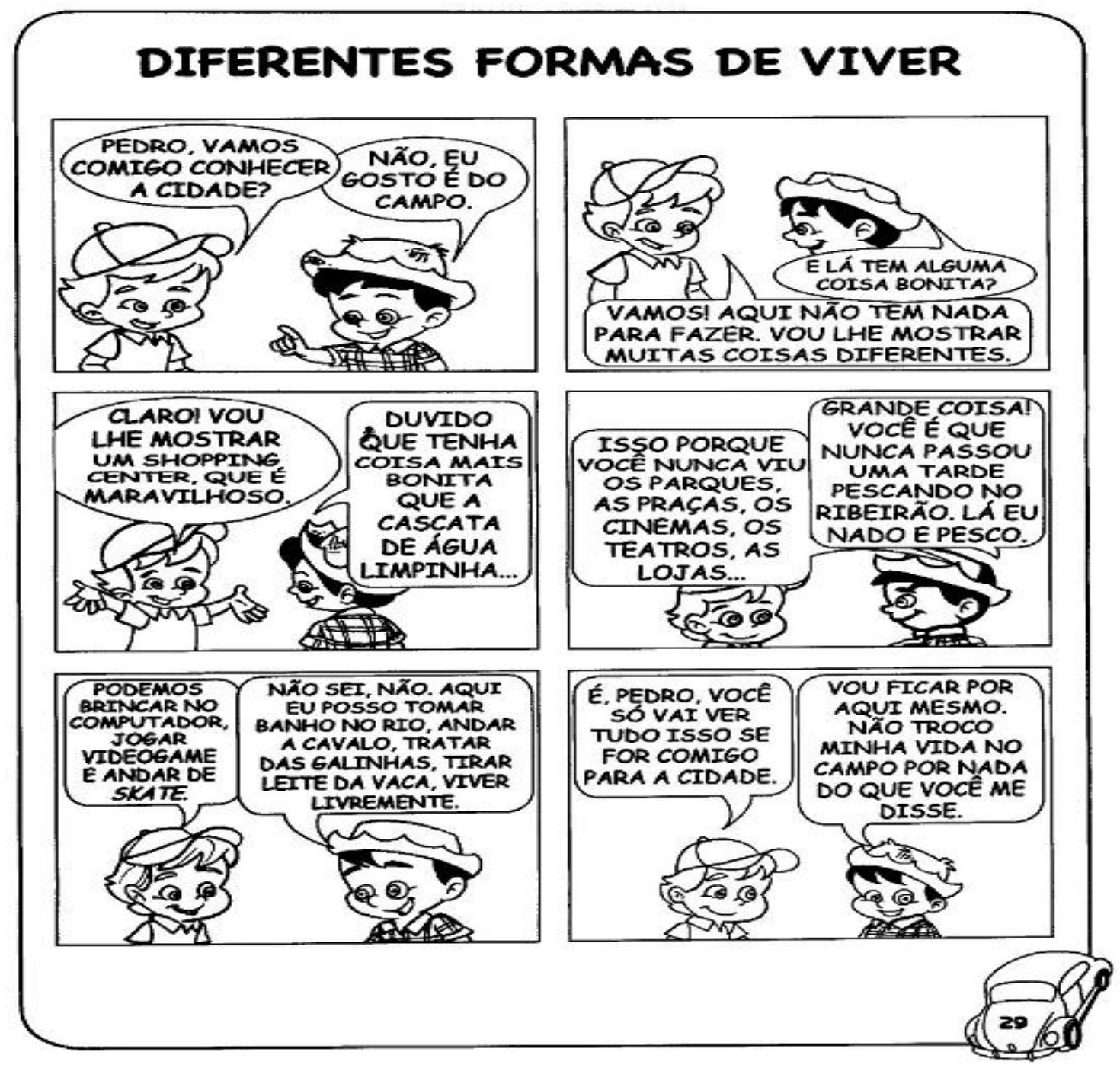

Fonte:<https://profclaugeohist.blogspot.com/2011/08/diferenca-entre-campo-e-cidade.html>. 
Após a leitura da HQ foi perguntado aos estudantes "Quais os objetos de conhecimento da Geografia que estão presentes nos quadrinhos?" A participação da turma foi muito grande, os alunos logo começaram a responder: a cidade, o campo professor, o rural, as diferenças entre a cidade e o rural, é de lá que vem a nossa comida. Percebemos que os estudantes começaram a ver a Geografia com outros olhos, como conhecimento para entender/compreender o local onde vivem, e também como um saber com diferentes utilidades/possibilidades para realizar leituras em relação a fatos/situações/acontecimentos que ocorrem no bairro onde moram, no Brasil e no mundo, a partir de uma visão de análise em distintas escalas geográficas, partindo do micro ao macro e vice-versa.

Na sequência da aula, foram trabalhados os objetos de conhecimento urbano, rural e, suas principais características, bem como, a presença desta temática e espaço no nosso cotidiano e suas implicações na vida da gente. Na parte final da aula, como forma de verificação da aprendizagem, foi solicitado aos estudantes presentes, que elaborassem uma $\mathrm{HQ}$, contemplando os objetos de conhecimento estudados. Nesse momento da aula também foi explicado aos alunos como montar e estruturar o enredo de uma história em quadrinhos, a melhor forma de escolher os personagens, os recursos de comunicação para expressar a fala dos personagens e o cenário a ser escolhido para a historinha.

A produção das HQs foi significativa e mostrou habilidade e criatividade por parte dos alunos. Assim, a (Figura 3), feita por um dos estudantes da turma procura mostrar como são constituídos os meios: urbano e rural. Embora, o aluno que produziu a $\mathrm{HQ}$ tenha utilizado muito pouco a linguagem escrita, apenas três palavras, a leitura geográfica dos quadrinhos permite ao leitor visualizar as principais características presentes em cada um dos dois diferentes ambientes representados pelo desenho.

O início da história começa no espaço urbano, na escola, local onde os alunos estudam e que recebe estudantes de diferentes lugares, incluindo os que moram no perímetro rural e/ou em outro município próximo. Posteriormente, no dia seguinte, os estudantes vão visitar a casa de um colega que mora no espaço rural, que na HQ é percebido através do despertar do dia pelo canto do galo, a criação de animais como a vaca, o gatinho que bebe o leite recém tirado da vaca, e a colheita de frutas reali- 
zada pelas crianças que as consomem junto à frutífera.

A opção pela não utilização da linguagem escrita como principal recurso emissor da mensagem pelo autor tornou a leitura da $\mathrm{HQ}$ bastante interessante, pois ao invés do tradicional texto, que normalmente costuma guiar a história, temos as imagens (paisagens), que remetem aos ambientes urbano e rural, que proporciona múltiplas interpretações/inquietações por parte do leitor tornando a atividade muito mais desafiante e prazerosa ao mesmo tempo, tanto para quem a faz a $\mathrm{HQ}$, quanto para quem a lê. Expressões faciais, movimentos do corpo (gestos), o canto do galo e o olhar dos personagens também foram usados como mecanismos transmissores de uma mensagem.

Figura 3 - O urbano e o rural a partir de uma $\mathrm{HQ}$
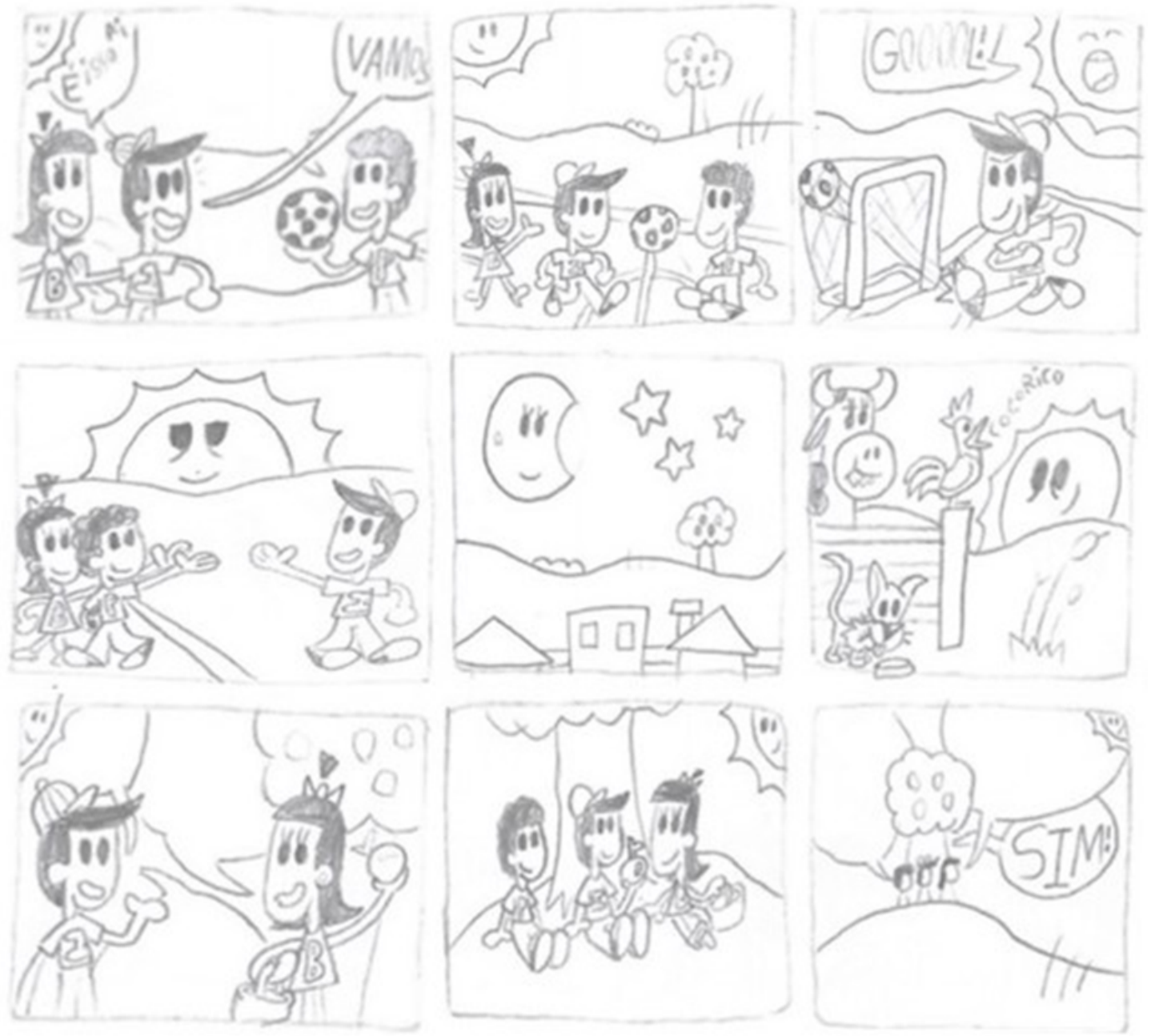

Elaborado por: estudante da turma 7C, agosto de 2019.

Tiveram alunos que optaram por escrever a história em quadrinhos com diálogos e com imagens sobre o que para eles são os dois espaços e mundos retratados 
na aula. Da mesma forma, a história marcou a percepção dos alunos e também os conhecimentos prévios e os adquiridos durante as aulas, onde os estudantes com sua exposição vão além da simples resolução de problemas envolvendo a Geografia, mas participam da construção do conhecimento de forma mais prazerosa e ativa, por meio da criação, do inventar e do ser inventor.

Desse modo, as HQs podem ser utilizadas de diferentes maneiras na sala de aula. Podem ser empregadas como um recurso pedagógico, que vai auxiliar o docente a ministrar as suas aulas e a trabalhar os diferentes objetos de conhecimento, mas pode também, ser o produto de uma criação autoral por parte dos próprios estudantes como forma de entendimento dos diferentes saberes escolares, cabe, nesse sentido, ao professor escolher a maneira, que fica melhor durante as suas práticas pedagógicas a inserção das HQs nas aulas de Geografia.

\section{E ASSIM...}

Neste capítulo foram tratadas as potencialidades da utilização da linguagem das HQs como recurso didático para o ensino de Geografia, nos anos finais do Ensino Fundamental. Ao propor a utilização das HQs teve-se o intuito de repensar o nosso fazer pedagógico em sala de aula, por meio de uma metodologia que privilegia a construção do conhecimento que, favoreça o aluno a explorar a sua criatividade, que estimule o desenvolvimento do senso crítico e que a atividade possa ser encarada de forma prazerosa/divertida e não obrigatória, imposta pelo professor, que só é realizada pelos estudantes se a mesma "vale nota", caso contrário, os alunos não se sentem motivados em realizar as atividades propostas em sala de aula pelos docentes.

As HQs, enquanto recurso didático, favorecem a exploração do imaginário e do poder de criação no aluno. Ainda, elas permitem, a partir da sua linguagem, a compreensão de como se deu/dá/dará a construção do espaço geográfico pela ação humana constituindo diferentes territórios, transformando a paisagem dos lugares pelo trabalho e formatando regiões a partir da seleção de critérios/variáveis de maior relevância, interesse e/ou a partir das culturas presentes em determinado espaço que passaram a formar regiões.

Além de potencializar o entendimento da ciência geográfica e do mundo onde o aluno está inserido, as HQs permitem o intercâmbio desse conhecimento com os 
saberes dos demais componentes curriculares e também o extraescolar, favorecendo assim, o aprendizado e o entendimento por parte do aluno de que no mundo nada funciona/existe de maneira isolada, são as diferentes conexões e fluxos que permitem que as "coisas" tenham sentido/utilidade para a vida.

\section{REFERÊNCIAS}

BECKER, Fernando. O que é construtivismo. Ideias, São Paulo-SP: FDE, n. 20, p. 87-93, 1993.

CASTROGIOVANNI, Antonio Carlos et al. Ensino de Geografia: caminhos e encantos. 2. ed. Porto Alegre-RS: Editora da PUCRS, 2011, 111p.

CAVALCANTI, Lana de Souza. Geografia e práticas de ensino. Goiânia-GO: Editora Alternativa, 2002.

COSTA, Rafael Martins da. Geografias em quadrinhos: imaginando um mundo em sala de aula. 2012. 112f. Dissertação (Mestrado em Geografia) - Universidade Federal do Rio Grande do Sul, Porto Alegre, 2012.

COSTA, Marsoniel Felipe da. Os quadrinhos em sala de aula. 2011. 17f. Monografia (Licenciatura em Letras) - Universidade Estadual da Paraíba, Guarabira-PB, 2011.

DEFFUNE, Gláucia. Relato de uma experiência de história em quadrinhos no ensino da Geografia. Boletim de Geografia, Maringá-PR, v. 28, n. 1, p. 157-169, 2010.

DOS SANTOS, Roberto Elísio.; VERGUEIRO, Waldomiro. Histórias em quadrinhos no processo de aprendizado: da teoria à prática. EccoS - Revista Científica, São Paulo-SP, n. 27, p. 81-95, 2012.

KAERCHER, Nestor André. A Geografia é nosso dia-a-dia. Boletim Gaúcho de Geografia, Porto Alegre-RS, v. 21, p. 109-116, 1996.

MELO, Kelli Carvalho.; MEDEIROS, Adriana Francisca de.; SILVA, Adnilson de Almeida. Uma linguagem alternativa no ensino escolar: as histórias em quadrinhos na mediação do ensino e aprendizagem da geografia. Ateliê Geográfico, Goiânia-GO, v. 7, p. 260- 283, 2013.

NERYS, Victor Hugo da Silva.; FREITAS, Anniele Sarah Ferreira. Histórias em Quadrinhos no ensino de geografia: possibilidades e propostas. p. 325-333. In: ENCONTRO REGIONAL DE ENSINO DE GEOGRAFIA, 6., 2018. Campinas-SP. Anais... Campinas-SP, 19 a 21 de out. de 2018.

\section{8}


PIEROZAN, Vinício Luís. O professor, o aluno e a educação em meio a uma pandemia: o ensino de Geografia na EMEF Professor Thiago Wurth. In: DA SILVA, Ana Paula et al. Saberes em Diálogo [recurso eletrônico]: na rede, com a rede, para além da rede. 1. ed. Canoas-RS: PMC/SME-UNILASALLE, 2020. p.938-950.

\section{ROHDE, Melina Dornelles Severo. Percepção dos problemas ambientais urbanos}

a partir do uso de mapas mentais: uma proposta de educação ambiental crítica/ emancipatória em escola urbana de Rosário do Sul - RS. 102f. Dissertação (Mestrado em Geografia e Geociências) - Universidade Federal de Santa Maria, Santa Maria, 2012.

SANTOS, Cláudia Rodrigues Costa dos. Atividades sobre Diferença entre campo e cidade. In: SANTOS, Cláudia Rodrigues Costa dos. História e Geografia... tô por dentro. Guapé-MG, 31 ago. 2011. Disponível em: <https://profclaugeohist.blogspot. com/2011/08/diferenca-entre-campo-e-cidade.html>. Acesso em: 6 jan. 2021.

SEVERO, Melina Dornelles.; MANFIO, Vanessa. O uso de charges como instrumento para trabalhar com educação ambiental voltado para o problema do lixo no meio ambiente. p. 283-292. In: ENCONTRO DE PRÁTICAS DE ENSINO DE GEOGRAFIA DA REGIÃO SUL, I., 2013, Porto Alegre-RS. Anais... Porto Alegre-RS, 20 a 22 de jun. de 2013.

TESTONI, Leonardo André.; ABIB, Maria Lúcia Vital dos Santos. A utilização de histórias em quadrinhos no ensino de física. In: ENCONTRO NACIONAL DE PESQUISA EM EDUCAÇÃO EM CIÊNCIAS (UNESP), 4., 2003, Bauru-SP. Anais... Bauru-SP: Unesp, 2003 (CD-ROM).

VERGUEIRO, Waldomiro. Uso das HQs no ensino In: RAMA, Angela.; VERGUEIRO, Waldomiro. (Orgs.). Como usar as histórias em quadrinhos na sala de aula. São Paulo-SP: Contexto, 2010. 


\section{AS PERCEPÇÓES DOS PROFESSORES} DE GEOGRAFIA EM RELAÇO ÀS REFORMAS CURRICULARES

\section{DO ENSINO MÉDIO}

MATHEUS HENRIQUE DE ASSIS REIS

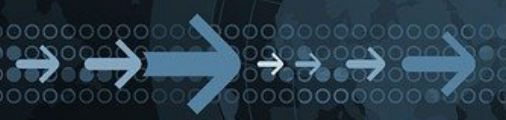
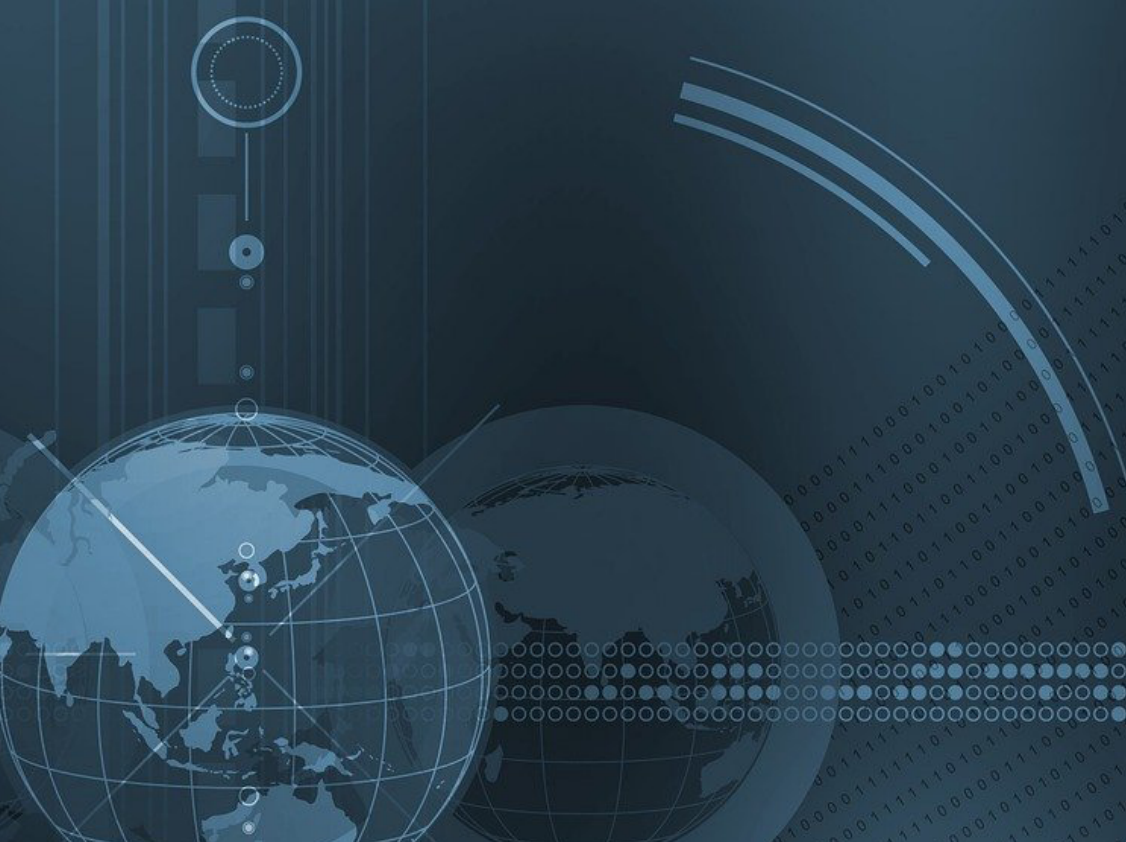

1 Discente do curso de Geografia (licenciatura) do Instituto de Estudos Socioambientais (IESA) da Universidade Federal de Goiás (UFG). Membro do Laboratório de Estudos e Pesquisa em Educação Geográfica (LEPEG). Integrante do Núcleo de Pesquisa em Ensino de Cidade (NUPEC). Bolsista de Iniciação Científica Pró-Licenciatura.

E-mail: matheushenrique.ufg@gmail.com 


\section{INTRODUÇÃo}

O Ensino Médio se caracteriza como os três últimos anos de formação escolar, a fase final da Educação Básica. Um período marcado por transformações significativas, estágio em que os jovens se veem com a necessidade de terem que tomar decisões, as quais irão, na maioria das vezes, gerar impactos em longo prazo nas suas vidas.

De acordo com Krawczyk (2011), cursar o Ensino Médio para alguns grupos sociais é algo natural, que faz parte do seu universo, da sua cultura, do lócus de inserção familiar. Refere-se a um momento em que é possível vislumbrar recompensas, ganhos por estar cursando ou em cursar essa fase da educação, assim como uma etapa em que se pode atingir objetivos, sejam pessoais ou não, como o ingresso na universidade.

Contudo, segundo Krawczyk (2011), existem realidades sociais que não possibilitam um acesso ou realização do Ensino Médio, ou mesmo não possuem essa tradição em sua dimensão cultural, familiar e social. Um dos motivos que se destaca, sobretudo em relação a evasão escolar, é a baixa renda familiar que muitos jovens têm de conviver cotidianamente, o que os leva a terem de trabalhar, desde criança, para contribuir com as despesas de casa, o que acaba tornando os estudos enfadonhos, sem muitas perspectivas.

Nesse contexto de singularidades em relação ao Ensino Médio, de ser uma fase que ainda não possui certa consistência, e que ainda passa por diferentes transformações, é que se desponta a chamada "Reforma do Ensino Médio", classificada como uma mudança necessária e que irá surtir benefícios a esse estágio da Educação Básica.

Para Morais et al (2018), essa reestruturação das políticas educacionais proposta pelo Banco Mundial, traz consigo o discurso de uma melhora na aprendizagem. Essa questão se orienta pela ideia de que não precisa haver uma reestruturação do Ensino Médio, pois problemas como a evasão escolar não são frutos de um sistema desestruturado e inconsistente, mas do caráter acadêmico atribuído a esse período. Assim, a carência de uma identidade própria e sólida para o Ensino Médio passa a

\section{1}


ser atribuída a uma estrutura curricular que não faz com que os alunos tenham interesse pelas aulas (MORAIS et al, 2018).

Nesse contexto de reformas curriculares, algumas disciplinas acabam sendo impactadas diretamente, como é o caso da Geografia e das outras disciplinas ligadas a área de Ciências Humanas e Sociais Aplicadas (História, Filosofia e Sociologia). Há uma preocupação de que a Geografia perca sua autenticidade, e os conteúdos desse componente curricular, que são importantes para a formação humana não sejam mais trabalhados, ocasionado assim, um prejuízo na formação do pensamento geográfico dos estudantes.

Pensando nessas questões é que o presente texto procura trazer alguns elementos que tenho investigado no plano de trabalho "Pesquisa com professores do Ensino Médio em Goiás: as reformas curriculares e sua influência na prática docente na rede estadual de ensino", do Programa de Iniciação à Pesquisa das Licenciaturas (PROLICEN-UFG), vinculado ao projeto de pesquisa coletivo "Percepções dos professores de Geografia do Ensino Médio em Goiás: as reformas curriculares e suas influências na prática docente" do Núcleo de Pesquisa em Ensino de Cidade (NUPEC).

\section{METODOLOGIA}

Neste trabalho aborda-se a percepção do professor de Geografia do Ensino Médio em Goiás sobre as mudanças nas políticas públicas curriculares e as influências na prática docente. Para o desenvolvimento desta investigação destaca-se como procedimentos o levantamento bibliográfico e documental sobre a temática e a realização de entrevistas e observação com professores da rede estadual de Goiás que trabalham com a disciplina de Geografia no Ensino Médio.

Durante a observação e entrevista buscou-se elementos que envolvem a leitura dos aspectos materiais, físicos e socioeconômicos da escola. Analisou-se também como os espaços da escola são organizados, estruturados e em que medida isso traduz valores ou condições específicas de trabalho, tendo como principais elementos:
a) a percepção da relação dos professores com os estudantes;
b)o conhecimento da forma como os professores tecem seus planos de aula, considerando ou não as reformas curriculares; 
c) quais as expectativas dos professores em relação à escola e em que medida vinculam a rotina de trabalho a suas experiências pessoais;

d) o conhecimento das formas de gestão de ações e a organização do projeto político pedagógico da escola, do funcionamento, dos papéis estabelecidos e das normas instituídas e partilhadas pela comunidade escolar.

Nesse sentido, buscou-se realizar uma análise, por meio da percepção de professores, de como as reformas curriculares do Ensino Médio vão gerar consequências às aulas de Geografia. Pois, na medida em que a Geografia, uma ciência que possui um saber e uma característica essencial para a formação dos indivíduos, bem como o despertar do senso crítico e reflexivo, perde a sua identidade individual, preocupa-nos sobre quais serão os impactos disso para o ensino e para a formação cidadã dos estudantes.

A defesa da Geografia se dá pela reflexão que essa disciplina constrói nos jovens estudantes, bem como a sua relevância em relação às análises socioespaciais que são empreendidas, sendo assim, uma ciência essencial para a compreensão dos sujeitos.

\section{RESULTADOS E DISCUSSÃO}

\section{O ENSINO MÉDIO E A GEOGRAFIA NO CONTEXTO DAS REFORMAS CURRICULARES}

Analisar, pensar e refletir sobre o sistema educacional brasileiro, trata-se de algo complexo e que demanda, impreterivelmente, de bases investigativas que possibilitem chegar a uma possível compreensão a despeito. Essa dificuldade se dá especialmente em função das transformações que a educação vem passando nas últimas décadas no Brasil, sobretudo a educação básica (Ensino Fundamental I e II e Ensino Médio). Com relação ao Ensino Médio, “[...] é consensual a percepção de que o ensino médio é o nível de ensino que provoca os debates mais controversos, seja pelos persistentes problemas do acesso e da permanência, seja pela qualidade da educação oferecida, ou, ainda, pela discussão sobre a sua identidade" (KRAWCZYK, 2011, p. 754). Cabe ressaltar que tal instabilidade ao tratar sobre o Ensino Médio, 
também é fruto de um descaso do poder público, ou mesmo da forma como essa etapa da formação é tecnicamente vista pela sociedade, isto é, a concepção de que essa é meramente a porta de entrada ou trampolim para o Ensino Superior.

O Ensino Médio passa a ser um universo de construções e desconstruções, onde não há bases coerentes que possam dar sustentabilidade, há uma ausência de coesão nessa fase de formação. A Lei de Diretrizes e Bases da Educação (LDB) em seu artigo 35 aponta algumas finalidades a serem cumpridas na fase do Ensino Médio, essas são:

I - a consolidação e o aprofundamento dos conhecimentos adquiridos no ensino fundamental, possibilitando o prosseguimento de estudos;

II - a preparação básica para o trabalho e a cidadania do educando, para continuar aprendendo, de modo a ser capaz de se adaptar com flexibilidade a novas condições de ocupação ou aperfeiçoamento posteriores;

III - o aprimoramento do educando como pessoa humana, incluindo a formação ética e o desenvolvimento da autonomia intelectual e do pensamento crítico;

IV - a compreensão dos fundamentos científico-tecnológicos dos processos produtivos, relacionando a teoria com a prática, no ensino de cada disciplina. (BRASIL, 1996, s./p.)

Contudo, uma vez que se realiza uma comparação entre as metas a serem cumpridas pela LDB, e a realidade percebida no cotidiano escolar, nota-se que existem distanciamentos entre a teoria e a prática. A começar pelo aprofundamento daqueles conteúdos que são trabalhados no Ensino Fundamental e que devem ser revistos no Ensino Médio, entretanto, quando isso ocorre é de maneira rápida, sem um aprofundamento necessário, principalmente pela série de cobranças que são realizadas, sobretudo em relação a notas que alavancam ou não os índices da educação. Logo, em virtude dessa agilidade contínua do modo de se trabalhar no e com o Ensino Médio, isso faz com que as outras expectativas sejam praticamente anuladas. O conteúdo para ser apreendido perpassa a lógica do estudo, diálogo, compreensão e prática, ou seja, requer um tempo razoável para que o aprendizado ocorra.

Na lei $n^{\circ} 13.415$, a qual realiza alterações da lei $n^{\circ}$ 9. 349 (LDB), fica previsto em seu art. 36 que o currículo base/referência para o Ensino Médio passará a ser 
"[...] composto pela Base Nacional Comum Curricular e por itinerários formativos, que deverão ser organizados por meio da oferta de diferentes arranjos curriculares, conforme a relevância para o contexto local e a possibilidade dos sistemas de ensino [...]" (BRASIL, 2017)1. Desse modo, apresenta-se como mais uma mudança drástica e que acaba enfraquecendo as bases, ainda inconsistentes, do Ensino Médio. Uma mudança que até pouco tempo encontrava-se em processo de implementação, agora vem tornando-se realidade, se trata de algo que requer atenção, em especial por parte daqueles que serão afetados diretamente, professores e alunos.

No que diz respeito à Geografia, mediante o que a Base Nacional Comum Curricular (BNCC) aponta-se que ela, assim como as outras ciências humanas (História, Filosofia e Sociologia) serão condensadas e agrupadas em um itinerário formativo denominado de Ciências Humanas e Sociais Aplicadas (BRASIL, 2017a). Portanto, a Geografia, não diferente das outras áreas, acaba perdendo muito em relação a sua amplitude de conhecimento e possibilidades de se estudar em sala de aula, visto que nessa nova ótica a ideia é de uma disciplina interdisciplinar, que foque em assuntos gerais do campo das Ciências Humanas, e não nos aspectos específicos. Diante dessa flexibilização, evidencia-se uma afirmação de Cavalcanti (2013) que, embora suscitada em outro contexto, insere-se de forma alusiva ao atual estágio de enfrentamento da Geografia para se manter viva no ambiente escolar. Para a autora:

[...] se a Geografia permanece na escola como parte de projetos de formação geral deve ser porque os conteúdos que ela veicula tem significado nessa formação; deve ser porque seus conteúdos ajudam a compreender o mundo e sua dinâmica social; deve ser porque, com eles, é possível agir nesse mundo com mais consciência, com mais criticidade, com maior compromisso social.

Estará assim a Geografia a serviço da superação dos problemas do mundo contemporâneo e de seus paradoxos [...]. (CAVALCANTI, 2013, p. 46)

$1 \quad$ Nesse contexto, conforme Morais et al (2018), o Ensino Médio passa a ser configurado a partir de quatro áreas do conhecimento: Linguagens, Matemática, Ciências da Natureza e Ciências Humanas. Nessa nova perspectiva, indica-se a necessidade em se estabelecer uma interdisciplinaridade, meios que articulem diferentes campos do saber. É preciso "[...] garantir a educação tecnológica básica; o conhecimento do processo histórico de transformação social e cultural; a língua portuguesa como instrumento de comunicação e acesso ao conhecimento e exercício de cidadania; as metodologias diferenciadas; o domínio de princípios científicos e tecnológicos e as formas contemporâneas de linguagem" (MORAIS et al, 2018, p. 525). 
A partir do que fora descrito, vislumbra-se os desafios que serão enfrentados pelos professores de Geografia. Desse modo, reitera-se a discussão da afirmação em que Libâneo e Pimenta (1999, p. 258) afirmam que "a atividade docente vem se modificando em decorrência de transformações nas concepções de escola e nas formas de construção do saber, resultando na necessidade de se repensar a intervenção pedagógico-didática na prática escolar". Ou seja, caberá ao docente ter de se adequar, reinventar a sua prática no ambiente escolar. Logo, Krawczyk (2011, p. 765) contribui ao afirmar que "um dos grandes paradoxos presentes nas escolas é a necessidade de professores cada vez bem mais formados, motivados e atualizados, que convivem com um processo de deterioração do trabalho docente e políticas de formação que não condizem com os desafios contemporâneos". Ou seja, professores que estejam aptos a lidar com as adversidades do processo educacional, buscando reaver, ou mesmo construir uma relevância da Geografia para os alunos do Ensino Médio, o que, de acordo com Callai (1999), por vezes isso não se dá, os discentes não veem sentido em se estudar a referida disciplina.

\section{UM OLHAR ACERCA DA CONCEPÇÃO DO PROFESSOR DE GEOGRAFIA SOBRE AS REFORMAS CURRICULARES EM GOIÁS}

Em busca de uma análise e compreensão do posicionamento dos professores em relação ao modo como eles veem as reformas curriculares em Goiás, foi estabelecido um questionário com oito perguntas, as quais foram respondidas após um período de observação nas escolas-campo da pesquisa. O foco desse questionário foi a percepção do professor de Geografia sobre as possíveis mudanças em sua prática a partir das discussões de uma mudança curricular.

Nesse contexto, vale ressaltar, que a pesquisa está em desenvolvimento e os dados aqui trabalhados refletem o período de observação do ano letivo de 2019. A seguir, destaca-se algumas questões que foram foco de análise no período e as respectivas percepções dos professores que estão sendo acompanhados:

A primeira questão envolve o entendimento dos professores sobre o que já foi implementado da reforma do Ensino Médio em Goiás. Nesse aspecto ressalta-se que em Goiás, assim como em outros estados da federação, a reforma vem sendo implantada paulatinamente, visto que os estados, como um todo, vêm buscando ade- 
quarem-se à nova formulação de ensino aos poucos.

Esse contexto se dá pelo fato de também estarem adequando seus documentos (currículo referência estadual) ainda em consonância com as alterações estabelecidas pela BNCC (Base Nacional Comum Curricular) e as retificações da LDB (Lei de Diretrizes e Bases da Educação). Assim, a conjuntura de Novo Ensino Médio (NEM - como vem sendo conhecido) vem se impondo, até então, no ensino noturno, o qual já passa por alterações ao longo dos anos, inicialmente com o EJA (Ensino de Jovens e Adultos) e depois, mais recentemente, com o PROFEN (Programa de Fortalecimento do Ensino Médio Noturno).

Atualmente esse "NEM" é configurado na divisão do Ensino Médio (EM) em um regime semestral, visto que cada dois semestres correspondem a uma série do que antes era o EM, ou seja, o ensino regular. Cada um desses semestres é subdividido em dois bimestres, o que acarreta mudanças circunstanciais, que serão descritas posteriormente.

Outro ponto considera o entendimento dos professores sobre a reforma do Ensino Médio, destacando que a reforma afeta a disciplina de Geografia. Nesse sentido, percebe-se por meio das observações e entrevistas que os docentes ficam receosos em relação às mudanças que a reforma implica, sobretudo em detrimento das chamadas áreas do conhecimento, tal como a divisão do ENEM (Exame Nacional do Ensino Médio). Afinal, essa divisão em áreas gera uma diminuição, a certo modo, ao menos em primeiro instante, do número de professores da rede estadual, visto que não será mais ministrada aquela série de disciplinas que são conhecidas tipicamente no EM.

No que tange a Geografia, percebe-se uma preocupação a respeito da permanência dessa disciplina no Ensino Médio, principalmente pela compactação das disciplinas de Ciências Humanas (Geografia, História, Filosofia e Sociologia) em uma única, que vem a ser a área das Ciências Humanas e Sociais aplicadas.

Tal medida que visualiza a divisão por áreas ignora o potencial formativo das disciplinas, fazendo com que os professores tenham um número exacerbado de conteúdos para ministrarem, além de promover a extinção de uma das principais premissas das disciplinas da área de Ciências Humanas, que é de despertar e desenvolver 
o olhar e o pensamento crítico dos jovens.

Na pesquisa também se tem investigado sobre possíveis mudanças na escola a partir da perspectiva do professor. Nesse quesito, os professores relatam uma preocupação com os encaminhamentos pedagógicos que vêm ocorrendo na escola. Preocupa-os o fato de terem que ensinar um significativo número de conteúdos em um curto espaço de tempo, não que isso já não fosse uma realidade, no entanto, intensificou-se.

$\mathrm{Na}$ questão da carga horária, pode-se dizer que ainda não houve mudanças, já documentos como o PPP (Projeto Político Pedagógico), vêm sendo atualizados para a nova configuração de ensino, o que acarreta buscar opiniões por parte dos professores em reuniões e momentos de atualizá-los em relação a como o documento será formulado.

Outra questão investigada refere-se à atuação do professor diante das reformas. Nos relatos dos professores nota-se preocupações pelo fato de o estado promover um ideal de medo para a classe docente. A insegurança sobre sua carga horária, transferências e até mesmo demissões (visto que essa última já vem sendo uma realidade anunciada, uma vez que o projeto para 2020 em muitas escolas é de não ter mais professores que sejam contratados), essas questões tem gerado um temor nos professores. Logo, boa parte dos professores criticam e manifestam-se em relação a essas reformas em núcleos individuais, que não os prejudiquem, até pelo fato de que muitos estão com mais tempo de carreira (concursados) e outros temem demissões (contratados).

Sobre os mecanismos de implementação da reforma nas escolas no campo da pesquisa, os professores apontam que a implementação vem ocorrendo gradativamente e sempre acompanhados por orientações aos docentes. Contudo, é inegável o receio que os professores possuem em função dessa reforma, afinal, são muitas mudanças e que por mais anunciadas que sejam, quando implantadas definitivamente, podem gerar impactos em sua ação e atuação profissional. 


\section{CONSIDERAÇÕES FINAIS}

O panorama da atual situação dos professores de Geografia que atuam no ensino de Geografia na rede estadual em Goiás revelam importantes questões para pensar a formação inicial e continuada dos professores. Os dados até o momento levantados têm subsidiado as pesquisas dos integrantes do Nupec e servido de base para o desenvolvimento dos estudos, leituras e aprofundamento das temáticas do grupo.

Dois pontos têm sido imprescindíveis para o desenvolvimento da pesquisa: a cumplicidade entre os professores pesquisadores e os professores observados/entrevistados. Considera-se que a pesquisa tem proporcionado aos membros do NUPEC, quanto aos professores de Geografia da rede pública de ensino uma discussão mais aprofundada sobre aspectos que direta e indiretamente afetam o ensino e a aprendizagem nas escolas goianas, e que precisam de ampla discussão crítica e consciente, pois entendemos que o professor orienta suas atividades por convicções e opções pedagógico-didáticas resultantes de sua formação inicial e continuada, e de sua prática, fundamentadas em concepções teórico-metodológicas e no papel que a Geografia escolar exerce na formação de alunos que participem ativamente no projeto social que defende.

Neste sentido, o entendimento sobre como o professor que atua com a disciplina de Geografia na rede pública de Goiás e o conhecimento sobre as políticas públicas e sua influência na prática docente tem contribuído com a valorização das Licenciaturas e a interação da Universidade com a rede pública de ensino.

Por fim, cabe ressaltar que a ampliação dos conhecimentos sobre políticas educacionais, sobre o Ensino Médio e uma compreensão da percepção do professor e suas relações têm apontado que as mudanças curriculares a incidência da internacionalização das políticas educacionais sobre o trabalho docente modifica estruturalmente o ensino escolar, excluindo determinadas formas de ensino e inserindo outras, padronizadas e mecanizadas, fazendo que o professor perca de vista cada vez mais seu objeto de trabalho - o conhecimento - e as formas conscientes de compreendê-lo, planejar e realizar seu ensino.

\section{9}




\section{REFERÊNCIAS}

BRASIL. Lei n 9.394, de 20 de dezembro de 1996. Estabelece as diretrizes e bases da educação nacional. Presidência da república - Casa Civil - Subchefia para Assuntos Jurídicos: Brasília: Diário Oficial da União, 23 de dezembro de 1996. Disponível em: http:// www.planalto.gov.br/ccivil_03/leis/L9394.htm. Acesso em: 20 jan. 2020.

BRASIL. Lei $n^{\circ} 13.415$, de 16 de fevereiro de 2017. Altera as Leis $n^{\circ} 9.394$, de 20 de dezembro de 1996, que estabelece as diretrizes e bases da educação nacional, e 11.494, de 20 de junho 2007, que regulamenta o Fundo de Manutenção e Desenvolvimento da Educação Básica e de Valorização dos Profissionais da Educação, a Consolidação das Leis do Trabalho - CLT, aprovada pelo Decreto-Lei $n^{\circ} 5.452$, de $1^{\circ}$ de maio de 1943, e o Decreto-Lei $n^{\circ} 236$, de 28 de fevereiro de 1967; revoga a Lei $n^{\circ}$ 11.161, de 5 de agosto de 2005; e institui a Política de Fomento à Implementação de Escolas de Ensino Médio em Tempo Integral. Presidência da república - Casa Civil Subchefia para Assuntos Jurídicos: Brasília: Diário Oficial da União, 16 de fevereiro de 2017. Disponível em: http://www.planalto.gov.br/ccivil_03/_ato2015-2018/2017/ Lei/L13415.htm. Acesso em: 20 jan. 2020.

BRASIL. Base Nacional Comum Curricular (BNCC) para o Ensino Médio. Ministério da Educação, Secretaria da Educação Básica. Brasília: MEC; CONSED, UNDIME, 2017a. D is pon ívele m: h t t p: / / portal.mec.gov.br/index. php? option=com_docman\&view=download \&alias = 8512 1 - b n c c - e n s i n o-medio\&category_slug=abril-2018-pdf\&ltemid=30192. Acesso em: 20 jan. 2020.

CALLAI, Helena Copetti. A Geografia no Ensino Médio. Revista Terra Livre, São Paulo, n. 14, p. 60-99, jan./dez., 1999. Disponível em: http://www.agb.org.br/publicacoes/index.php/ terralivre/article/view/375. Acesso em: 20 jan. 2020.

CAVALCANTI, Lana de Souza. Geografia escolar e a busca de abordagens teórico/ práticas para realizar sua relevância social. In: SILVA, Eunice Isaías da; PIRES, Lucineide Mendes (orgs.). Desafios da didática de Geografia. Goiânia: PUC-Goiás, 2013, p. 45-68.

KRAWCZYK, Nora. Reflexões sobre alguns desafios do ensino médio no Brasil hoje. Cadernos de Pesquisa, São Paulo, v. 41, n. 144, p. 752-769, set./dez., 2011. Disponível em: http://publicacoes.fcc.org.br/ojs/index.php/cp/article/view/70/86. Acesso em: 20 jan. 2020. 
LIBÂNEO, José Carlos; PIMENTA, Selma Garrido. Formação de profissionais da educação: visão crítica e perspectiva de mudança. Educação e Sociedade, Campinas, n 68, p. 239-277, jan./jun., 1999. Disponível em: https://www.researchgate. net/profile/Libaneo_Jose_Carlos/p u b l i c a t i o n / 262554988_Educational_professional_upbringingi_critical_view_and_changing_perspectives /links/55d73fe608aeb38e8a85a348.pdf. Acesso em: 20 jan. 2020.

MORAIS, Eliana Marta Barbosa de; SACRAMENTO, Ana Claudia Ramos; OLIVEIRA, Karla Annyelly Teixeira de; MORAES, Loçandra Borges de. Os documentos curriculares nacionais: a reforma do ensino médio e a disciplina Geografia. In: IX FORÚM NACIONAL NEPEG, 9, 2018, Caldas Novas. Anais [...]. Caldas Novas, p. 520-529, 2018. Disponível em: http://nepeg.com/newnepeg/wp-content/uploads/2017/02/ GT4_04_Os-documentos-curriculares-nacionais_-a-reforma-do-ensino-m\%C3\%A9dio-e-a-disciplina-Geografia.pdf. Acesso em: 20 jan. 2020. 


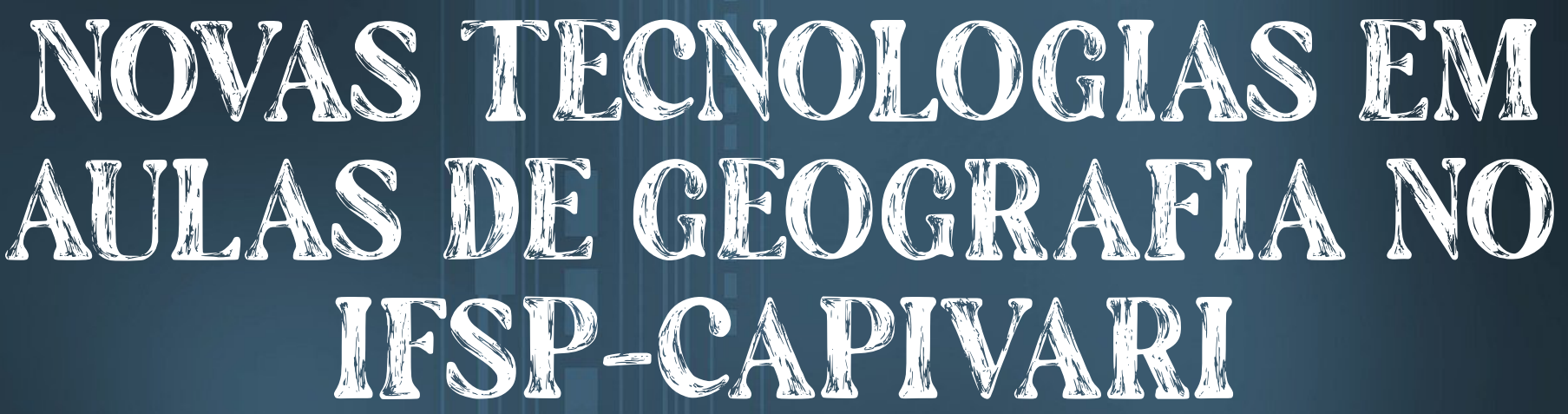

THALIA GARLA GAMPOS JÜLIO CÉSAR SUZURI
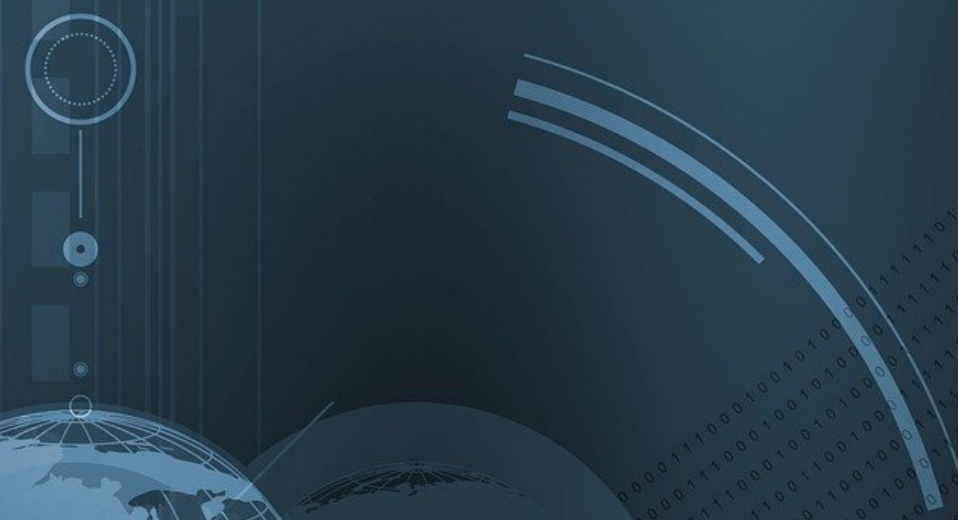

1. 0 Técnica em Informática (IFSP; 2015), graduada em Pedagogia (CUNSP, 2018) e especialis-

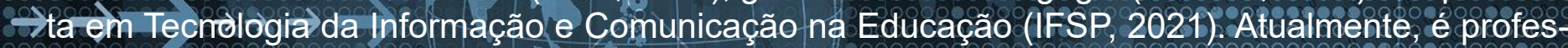
sora educadora no serviço de acolhimento da Associação Santa Rita. E-mail: thalliacarlacampos@ ifspcapivari.com.br.

2 Graduado em Geografia (UFMT, 1992) e em Letras (UFPR, 2004), com mestrado (USP, 1997) e doutorado (USP, 2002) em Geografia Humana e estágio pós-doutoral na Université Panthéon-Sorbonne (2007-2008), Université Rennes 2 (2014-2015) e Université de Pau et des Pays de l'Adour (2014-2015). Atualmente, é professor do Departamento de Geografia/FFLCH/USP e orientador junto ao Programa de Pós-graduação em Integração da América Latina (PROLAM/USP). E-mail: jcsuzuki@usp.br. ORCID ID: https://orcid.org/0000-0001-7499-3242. 


\section{INTRODUÇÃO}

Nos primórdios da evolução humana, o lápis, o fogo e a televisão foram considerados uma tecnologia, como forma de mediação para facilitar a vida dos seres humanos. Em nossa análise, utilizaremos o termo "novas tecnologias" à gama de recursos e instrumentos relativos ao universo digital, virtual e tecnológico, como: internet, computadores, celulares, ambientes virtuais.

As novas tecnologias trouxeram impactos preciosos e imensuráveis paradiversas áreas, relativas aos processos de produção, circulação e consumo, em vínculo com a $4^{\circ}$ revolução industrial, aportando à Educação diversos instrumentos, o que conduziu para a construção de um novo perfil de aluno, já que a geração atual é nativa no uso das novas tecnologias no ambiente exterior ao ambiente escolar. (ALMEIDA, 2001)

A experiência tecnológica, assim, facilita a sua incorporação nas mediações das práticas de ensino e de aprendizagem na Educação Básica, particularmente em momento específico em que se vive de ondas reiteradas de avanço da pandemia da COVID-19. Assim, é fundamental que a escola não se ausente da possibilidade de incorporar novos instrumentos na Educação, em que o professor desempenhe um papel de motivador e mediador entre essas novas tecnologias e o processo de apren-

dizagem, construindo novos caminhos a serem seguidos e conquistados por meio da contribuição das novas tecnologias para o desenvolvimento da aprendizagem dos alunos.

No entanto, não se pode esquecer da importância do debate relativo ao significado político, social e cultural que tais mediações tecnológicas aportam, particularmente em relação às dificuldades que existem para grande parcela de estudantes, cujos limites sociais impossibilitaram vivências consistentes de experimentação de novas tecnologias, com o uso de notebooks, celulares mais potentes, computadores velozes, dentre outros, conforme salientou Tori:

Enquanto se debate sobre as vantagens e desvantagens do uso da tecnologia na educação, novas gerações de estudantes estão chegando às escolas sem quaisquer dúvidas ou receios quanto ao uso das tecnologias de informação e comunicação em atividades do dia a dia. Não vai ser fácil para eles se adaptarem às escolas que não tiverem integrado as novas tecnologias à sua rotina. (TORI, 2010, p. 10-11) 
É preciso, assim, compreender o educando em seu contexto social, político, cultural, mediado por um universo multidimensional tecnológico e imagético, conforme aponta Moraes:

Não é suficiente adquirir televisão, videocassetes, computadores, sem que haja uma mudança básica na postura do educador. É preciso mais.A comunicação precisa ser instaurada desejada, conquistada. É necessário entender o educando como ser histórico, ativo e como tal, a atenção não pode centrar-se apenas no instrumento e na técnica [...]. Deve-se necessariamente considerar a influência das imagens no cotidiano do educando. E mais, deve-se observar o reflexo dessa influência de compreender a realidade na sua forma perceptiva, sensorial e cognitiva [...] multidimensional. (MORAES, 2000, p. 132)

Não só os discentes precisam ser avaliados em suas potencias e dificuldades, mas, também, os professores que, em geral não nasceram imersos ao universo tecnológico contemporâneo, são, assim, imigrantes digitais (PALFREY; GASSER, 2011), pois não dominam a maioria dos recursos disponíveis e necessitam aprender e ocupar seu espaço nesse novo mundo tecnológico, conhecendo suas potencialidades e limites, o que se tornou extremamente contundente neste momento de pandemia, com restrição da interação social presencial.

Pretendemos, assim, analisar a incorporação de novas tecnologias educacionais, em aulas de Geografia, do Instituto Federal de Educação, Ciência e Tecnologia de São Paulo (IFSP), com referência nos Cursos Técnicos em Química e em Informática do Ensino Médio no ano de 2020.

Com base em entrevista com o docente responsável pela disciplina de Geografia, no Campus de Capivari do IFSP, o Prof. Dr. Tiago José Berg, sobreas novas tecnologias e a importância de mudanças na postura docente frente ao novo perfil do educando, bem como aplicação de questionário junto aos alunos do Ensino Médio dos Cursos Técnicos de Química e de Informática, com foco na utilização das novas tecnologias em sua aprendizagem.

O IFSP é organizado em estrutura multicampi, cuja difusão das novas tecnologias ocorreu principalmente a partir de 2000, quando se deu a implantação de uma variedade de cursos voltados às tecnologias. Essa transformação avançou gradativamente fazendo com que a instituição ofertasse várias modalidades e níveis de formação, do Ensino Médio à Pós-graduação Stricto Sensu. 
Um dos campi do IFSP é o de Capivari que foi criado em 01/02/2010, vinculado inicialmente ao Campus de Salto. Suas atividades tiveram início com a oferta dos cursos técnicos concomitantes ou subsequentes em Manutenção e Suporte de Informática e Química.

Em 2012, foi firmada uma parceria com a Secretaria Estadual de Educação, onde o Campus Capivari começou a disponibilizar cursos técnicos integrados ao ensino médio nas áreas de Química e Informática. No primeiro semestre de 2013, foi iniciado o curso superior de Tecnólogo de Análise e Desenvolvimento de Sistemas.

O IFSP de Capivari utiliza as novas tecnologias para auxiliar no desenvolvimento de seus alunos, contemplando algumas metodologias eficientes como: a) Aprendizagem Baseada em Projetos (PBL), que foco na mobilização dos alunos na construção de projetos de longo ou curto prazo, enfatizando o uso de conhecimentos prévios para essa empreitada e o desenvolvimento da criatividade; b) Aprendizagem Baseada em Desafios ( $\mathrm{CBL}$ ), bem semelhante à baseada em problemas, em que o desafio consiste em ter como foco uma questão geral, e por meio dela criar questões orientadoras abrangendo um tema de cunho social; e c) Aprendizagem Baseada em Games (GBL), que utiliza os jogos para benefício da aprendizagem dos alunos dentro da sala de aula.

Todas essas metodologias são desenvolvidas por professores e alunos do IFSP - Campus Capivari, promovendo e estimulando nos alunos construções coletivas, despertando a curiosidade e o interesse em solucionar problemas relevantes e relacionados com causas sociais, o que busca fazer dos discentes o centro de sua aprendizagem, ressaltando a importância da Matética que possui foco na aprendizagem, distinta da Didática cujo sentido é o ensino. Assim, se busca o desenvolvimento das potencialidades dos discentes, com criação de estímulos, proposição de pesquisas e busca por soluções para problemas atuais por meio de construções e de intervenções, mobilizadas pelos professores, mas centrada nos discentes, o que exige que a aprendizagem seja extremamente ativa.

No que concerne à Geografia no ambiente escolar, é de fundamental importância a realização de atividades práticas, inclusive com trabalhos de campo, mediados por uma significativa base teórica, metodológica e histórica, em relação às observações e às experiências individuais e coletivas dos estudantes. Não se esquecendo 
que o professor não é mais o único que detém as informações em tempo real, já que as mesmas se multiplicam em mídias com velocidade praticamente instantânea, conforme já havia indicado David Harvey (1993) em relação à compressão espaço-temporal.

Assim, o uso de novos instrumentos podem contribuir para colocar o discente no centro de sua aprendizagem, com a utilização de instrumentos, como Google Maps, Hot Potatoes, Compendium, que oportunizam experiências que não eram imaginadas por seus professores quando eram estudantes do Ensino Médio, com formas de representação espacial muito distante das fotografias aéreas e dos mapas temáticos, extremamente importantes mas marcados por uma desatualização maior que estas novas mediações podem constituir, as quais requerem conhecimentos ou letramentos específicos, tanto por professores, quanto por alunos. (ALMEIDA, 2001).

As formas de aprendizagem no Campus Capivari do IFSP em relação às práticas pedagógicas do professor que fez parte do estudo de caso estão estreitamente ligadas ao uso das novas tecnologias.

O docente foco da pesquisa costuma apresentar seus conteúdos em lousa digital, adaptar textos utilizando o formato PDF (disponível para ser visualizado em dispositivo móvel, bastante utilizado pela grande maioria dos discentes do Campus Capivari do IFSP), o que permite uma maior aproximação com os discentes, inclusive, em momento extraclasse, contribuindo para a continuidade das problematizações de conteúdos iniciadas em sala de aula, bem como produzindo maior familiaridade nos usos do equipamento para a Educação.

Nessa mesma prática são utilizadas outras formas de aprendizagem, como organização de seminários com coleta de dados primários e secundários, em que os discentes são estimulados a pesquisarem e a construírem interpretações sobre os temas da Geografia.

Algumas tarefas são realizadas pelo site do instituto nomeado SUAP, uma interface completa, em que é possível inserir atividades, notas, documentos diversos, informes institucionais e dados pessoais dos alunos.

Seguindo essa linha, de uso de mediadores, algumas tarefas são realizadas pelo Moodle do IFSP, mas também peloGoogle Sala de Aula (GoogleClassRoom), uma ferramenta bastante importante do Google para o ensino remoto, em que a si- 
tuação atual do mundo, devido a pandemia, contribui para que muitos professores e alunos fossem levados a utilizar. Por estes e outros mediadores, o docente, também, divulga links de vídeos e de canais do YouTube.

Outras metodologias educacionais e tecnológicas são utilizadas pelo docente, como construção de mapas mentais e conceituais, além do uso de aplicativos específicos, como o Google Maps.

Assim, foi possível perceber que o professor Tiago José Berg faz uso das Novas Tecnologias tornando possível a troca de conhecimentos, participações e discussões dos alunos sobre o conteúdo de forma alternativa e não somente tradicional. O mesmo não utiliza apenas o computador, o celular e as novas tecnologias para preparar o material das aulas, mas ampara-se na tecnologia para estabelecer uma metodologia pedagógica bastante eficiente, resultando em uma relação com seus alunos mais próxima e agregadora, no sentido da construção de redes de conhecimentos discutida por Almeida:

O professor que associa a TIC aos métodos ativos de aprendizagem desenvolve a habilidade técnica relacionada ao domínio da tecnologiae, sobretudo, articula esse domínio com a prática pedagógica e com as teorias educacionais que o auxiliem a refletir sobre a própria prática ea transformá-la, visando explorar as potencialidades pedagógicas da TIC em relação à aprendizagem e à consequente constituição de redesde conhecimentos (ALMEIDA, 2001, p. 72)

Para o docente, é possível uma articulação entre o ensino com a plataforma física, fundamentalmente em papel, como livros, cadernos, mapas, e a digital, a das novas tecnologias, em que o significado do professor se altera para a condição de mediar da aprendizagem: "O modo tradicional possui suas vantagens, pois ensina a parar, respirar, refletir, pensar. As novas tecnologias são formasdiferentes de lidar com uma situação ainda sem resposta: como adaptar o modelo de escola do século XIX para uma escola do século XXI, que torne o ensino-aprendizagem interessante. O futuro nos reserva o papel de orientadores e mediadores muito mais do que os donos do conhecimento" (Entrevista com o Prof. Tiago José Berg).

Não é pequena a tarefa do professor, neste contexto de aumento no volume de informações, bem como na velocidade com que ela trafega: "Existem grandes desafios [ao ensino e à aprendizagem]. Infelizmente a tecnologia criou um mundo onde 
somos bombardeados de informações a todo instante e, muitas vezes, não conseguimos processar todo aquele conjunto de dados que chegam a nossas retinas. O conhecimento vem da reflexão, do parar para pensar, da abordagem do professor para criarestratégias de aprendizado que levem ao conhecimento do aluno. Podemos resumir tal processo em uma metáfora: antigamente o professor caminhava com os alunos sedentos em um deserto, ele batia o pau em uma pedra e vertia a água do conhecimento, instigando os alunos a beber. Hoje os alunos estão boiando em um imenso lago de informações, não falta água, mas não sabem achar um ancoradouro seguro. É o professor que tem de jogar as boias e conduzir os alunos até as zonas seguras do conhecimento" (Entrevista com o Prof. Tiago José Berg).

O docente, ainda, reconhece o papel positivo das novas tecnologias: "Sim, existem impactos positivos, pois o uso e domínio de equipamentos tecnológicos (computadores, tablets, celulares)e seus softwares e aplicativos (YouTube, Whatsapp, Prezi, Power Point, Facebook etc.) por parte dos alunos facilita o trabalho de pesquisa e ajuda a disseminar com mais facilidade os materiais de aula apresentados pelo professor. [...] Quando pensamos em um aluno utilizando um smartphone hoje, o acesso a gama de informações que ele possui hoje em dia é superior ao homem mais culto e rico de 50 anos atrás, porexemplo. Hoje é possível receber notícias instantaneamente, ler as manchetes dos principais jornais do mundo, acessar livros, bibliotecas, museus, lugares e bens culturais que antes estavam restritos às pessoas com maiores posses ou cultura. Nesse quesito, a tecnologia pode ajudar na construção do conhecimento" (Entrevista com o Prof. Tiago José Berg).

Para os discentes, está claro o uso das novas tecnologias utilizadas nas aulas de Geografia pelo Prof. Tiago José Berg, em que 100\% responderem que há algum recurso tecnológico para auxiliar a disciplina, ainda que $66,7 \%$ não tenha plena certeza de que o seu uso, pensando para além da Geografia, possa ser um aliado à prática docente no auxílio à aprendizagem, sendo que o diferencial está no esclarecimento dos propósitos para o seu uso, na visão dos estudantes.

Os discentes ainda poderaram que é importante ter cuidado com o uso das novas tecnologias, indicando o que seria fundamental: "Usar de uma forma que integre e ajude ao aprendizado e não o atrapalhe. Queo use com responsabilidade, evitando tornar a aula monótona ou cansativa"; "Criatividade é muito importante, não digo 
para criar coisas mirabolantes, masinvestir em práticas novas e que realmente ajudam no conteúdo e estimulem o aluno"; "Pensar no perfil dos alunos e escolher a melhor ferramenta para eles".

As observações feitas pelos discentes são essenciais para o aperfeiçoamento do trabalho do professor e melhorias em sua prática pedagógica. Um apontamento relevante é o levantamento conhecimentos prévios, para que o docente atinja seu aluno de forma significativa ele precisa conhecer sua realidade, seus interesses $e$ por sua vez compreender o perfil que está lidando e quais as alternativas que precisam ser tomadas para se alcançar o objetivo proposto.

\section{CONSIDERAÇÕES FINAIS}

As novas tecnologias auxiliam as atividades pedagógicas em sala de aula, com relevo para as possibilidades do discente participar ativamente da construção do seu conhecimento, o que toma relevo neste momento tão específico da pandemia pela COVID-19.

As novas tecnologias pode ser ter significado positivo para melhorar as aulas, as práticas em sala, mas devem ser pensadas e utilizadas com muita atenção para que ajudem e beneficiem os alunos e os professores na aprendizagem e no ensino, como se dá com o uso de celulares, lousa digital, projetor de slides, dentre outros instrumentos.

Atualmente, em que o mundo vive uma situação muito difícil com a pandemia pelo coronavírus a restrição à mobilidade permitiu repensar o uso da tecnologia como mediadora importante do ensino e da aprendizagem.

Escolas precisaram ser fechadas, encontros presenciais entre professores e alunos restringidos. Assim, para manter o processo educativo, foi necessário seguir com atividades remotas, não só as assíncronas, mas também as síncronas, com a utilização de aplicativos de reunião por meio digital, como o Google Meet.

Assim, professores que não tinham noção alguma sobre as tecnologias digitais da informação e comunicação (TDICs) precisaram se adaptar a esse novo mundo, aprendendo sobre utilização das redes sociais para se conectar com seus alunos, acesso a salas virtuais, uso de aplicativos indicados pelo governo etc., em que uma nova abordagem de ensino se expandiu sem ao menos os docentes e os discentes 
terem tempo de se prepararem para recebê-la.

Deste turbilhão, algo é certo: a mudança veio para ficar. Em que pese seu caráter seletivo socialmente e politicamente complexo, cujos resultados ainda são imprevisíveis.

\section{REFERÊNCIAS}

ALMEIDA, M. E. B. de. Educação, projetos, tecnologias e conhecimento.São Paulo: PROEM, 2001.

MORAES, Maria Cândida. O Paradigma Educacional Emergente. 16. Ed.Campinas: Papirus, 2000.

PALFREY, John; GASSER, Urs. Nascidos na era digital: entendendo a primeira geração dos nativos digitais. Porto Alegre: Artmed, 2011.

TORI, Romero. Educação sem distancia: as tecnologias interativas na redução de distancias em ensino aprendizagem. São Paulo: SENAC-SP, 2010. 
